UNIVERSIDADE DE SÃO PAULO

MUSEU DE ARQUEOLOGIA E ETNOLOGIA

PROGRAMA DE PÓS-GRADUAÇÃO EM ARQUEOLOGIA

JAQUELINE GOMIES SANTOS

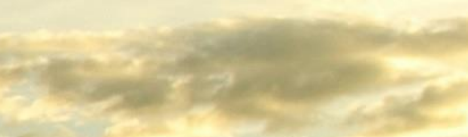

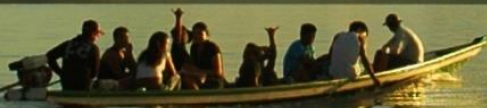

CRONOLOGIAE MUDANÇA CULTURAL NARDS AMANÃ (AMAZONAS): UM ESTUDO SOBRE A FASE CAIAMBÉ DA TRADIÇÃO BORDA INCISA

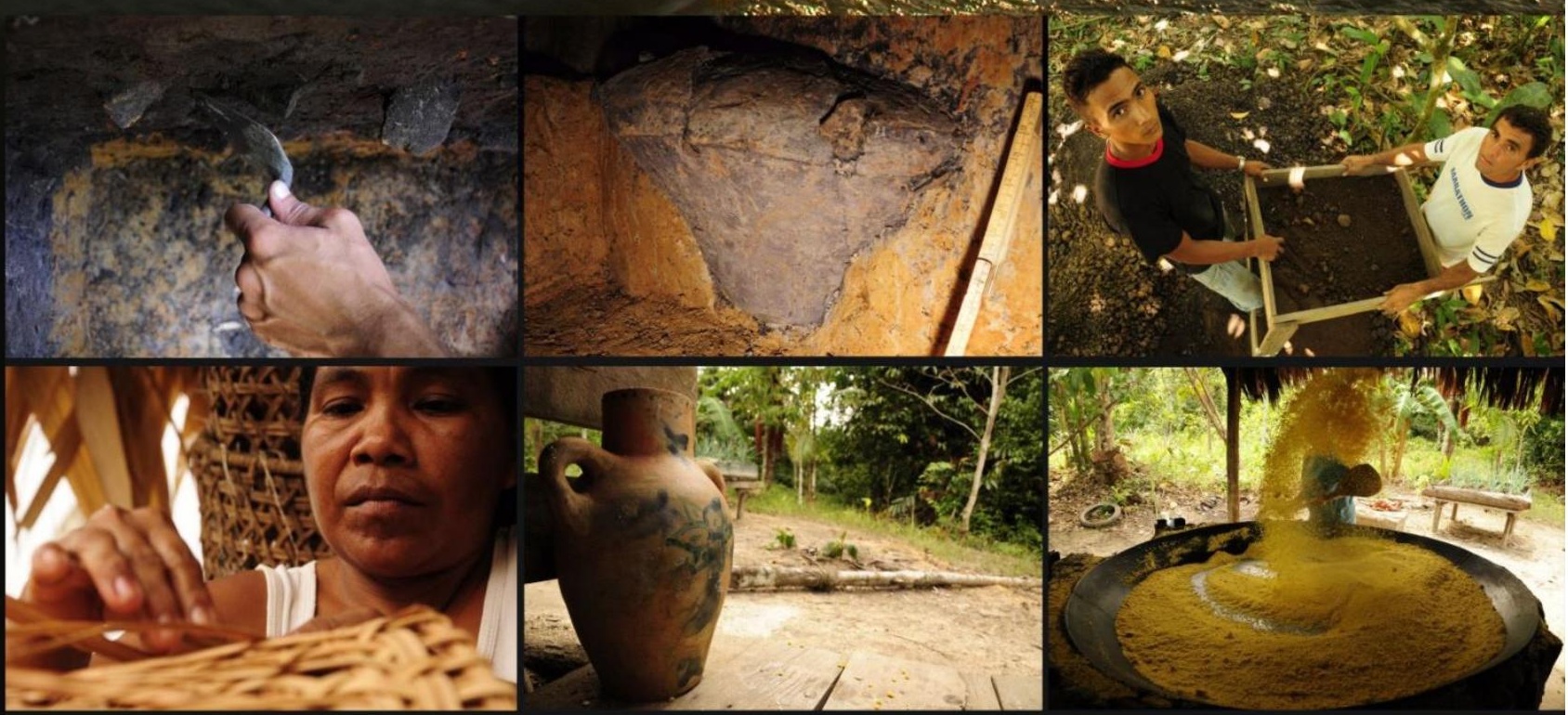

São Paulo

2015 
JAQUELINE GOMES SANTOS

\section{Cronologia e Mudança Cultural na RDS Amanã (Amazonas): \\ Um estudo sobre a Fase Caiambé da Tradição Borda Incisa}

Dissertação apresentada ao

Programa de Pós-Graduação em

Arqueologia do Museu de Arqueologia e Etnologia da Universidade de São Paulo para obtenção do título de Mestre em Arqueologia

Área de Concentração:

Arqueologia

Orientador:

Prof. Dr. Eduardo Góes Neves

Linha de Pesquisa:

Cultura Material e Representações

Simbólicas em Arqueologia

Versão original 


\section{RESUMO}

A tradição Borda Incisa envolve um debate intenso entre os pesquisadores por uma série de motivos, dentre os quais, por suas cerâmicas apresentarem uma grande variabilidade estilística e morfológica, devido sua ampla distribuição geográfica e sua associação aos contextos de terra preta. $\mathrm{Na}$ Amazônia Central o período relacionado às ocupações Borda Incisa é considerado de adensamento populacional e quando as mudanças nas paisagens são mais intensas, associadas aos falantes de línguas Arawak que teriam desenvolvido um sistema regional multiétnico com circulação de cerâmicas e compartilhamento de uma mesma cosmologia baseada na ocupação de aldeias circulares.

A Reserva de Desenvolvimento Sustentável Amanã, área focal dessa pesquisa, é uma unidade de conservação localizada na porção central do Estado do Amazonas. O objetivo da dissertação é contribuir para a construção de uma história cultural do Lago Amanã e a compreensão de sua antiga e intensa ocupação pré-colonial. A fase Caiambé é o recorte de análise, a partir do refinamento de suas características estilísticas e contextuais, procura-se compreender seus significados no quadro cronológico da Amazônia Central e suas relações com os complexos culturais anteriores e posteriores a ela. Através de escavações, datações e tratamento do material cerâmico, buscou-se oferecer refinamento da cronologia de ocupação. Alguns dos resultados apresentados são: contemporaneidade de assentamentos, caracterização de sítios com diferentes funções e maior caracterização da tecnologia de produção cerâmica. Com base nessas informações sugere-se a fase Caiambé no lago Amanã representa o ápice da ocupação integral de um território, com a formação de diferentes aldeias e espaços públicos e rituais.

Palavras-chaves: Fase Caiambé; Tradição Borda Incisa; RDS Amanã 


\begin{abstract}
The Incised Rim tradition involves an intense debate among researchers for a number of reasons, among which, for its ceramics present a great stylistic and morphological variability due to its wide geographic distribution and their association with terra preta contexts. In central Amazonia the period related to occupations Incised Rim is considered population density and when changes in the landscapes are more intense, associated with the Arawak language speakers who have developed a multi-ethnic regional system with circulation ceramics and sharing the same cosmology based on occupation of circular villages.

The Amana Sustainable Development Reserve, focal area of this research is a protected area located in the central portion of the state of Amazonas. The purpose of this work is to contribute to building a cultural history of the Lake Amana and understanding of its ancient and intense precolonial occupation. The Caiambé phase is the analysis of cut from the refinement of its stylistic and contextual features, try to understand their meaning in the chronological framework of the Central Amazon and its relations with the previous cultural complexes and subsequent to it. Through excavation, dating and treatment of ceramic material, it sought to provide refinement of the chronology of occupation. Some of the results are presented: contemporary settlements, characterization of sites with different functions and improved characterization of pottery production technology. Based on this information it is suggested to Caiambé phase at Lake Amana is the culmination of the full occupation of a territory, with the formation of different villages and public spaces and rituals.
\end{abstract}

Keywords: Caiambé Phase; Incised Rim tradition; SDR Amanã 


\section{AGRADECIMENTOS}

Ao CNPQ pelas diferentes bolsas de pesquisa concedidas a mim nos últimos cinco anos da minha trajetória acadêmica e profissional.

Ao Instituto de Desenvolvimento Sustentável Mamirauá pela infraestrutura de campo e laboratório, além do interesse nas pesquisas arqueológicas na Reserva Amanã. Aos funcionários do departamento de compras (Maura, Jenifer, Alan), logística (Cesar, Romulo), RH (Dolly), o pessoal do base (Seu Carlos, Erivelton), barco da troca e zeladores das bases de campo.

Ao Prof. Eduardo Góes Neves pela orientação, incentivo, e principalmente, por seu otimismo sempre.

Ao corpo de funcionários do Museu de Arqueologia e Etnologia da USP, entre os quais sou grata particularmente a Regina Leopoldo e ao Hélio Miranda.

Aos professores do Programa de Pós-gradução em Arqueologia, Fabíola Silva e Paulo DeBlasis que com seus cursos contribuíram imensamente para minha formação.

Cristiana Barreto e Juliana Machado também me permitiram conhecer bibliografias inspiradoras. A Fabíola Silva e Rui Murrieta, avaliadores da banca de qualificação, agradeço a leitura e sugestões no texto preliminar apresentado.

Agradeço aos moradores das comunidades do Lago Amanã, pelas histórias, causos e conversas sempre com muito café e açaí... à família de Dona Deuza e Seu Moisés, Seu Jota e D. Valdízia, Sineca e Zé Ariranha, Seu Luiz, Seu Solota, Dona Raimunda, Dona Maria e Seu Téo, Dona Elza e Negão, Dona Bebé e Seu Gerson, Seu Miguel e Dona Nicéia, Seu Mimi e D. Dica.. E tantos outros e suas crianças pelas beiradas, pelo acolhimento, atenção, disponibilidade em falar e ouvir, e por me ensinarem que distante é um lugar que não existe.

Este trabalho possui a contribuição direta de diversas pessoas às quais sou imensamente grata:

Bernardo Costa foi responsável pelo planejamento inicial e coordenação das atividades enquanto estive vinvulada ao Laboratório de Arqueologia do IDSM. Agradeço pela 
coordenação das escavações dos sítios aqui estudados. Laura Furquim, foi a pesquisadora que realizou análise de parte do material cerâmico objeto dessa pesquisa. Tereza Parente coordenou as atividades de Educação Patrimonial na RDS Amanã entre 2010 e 2012, durante as quais tive momentos privilegiados para compreender a relação dos moradores de Amanã e o patrimônio arqueológico. Marcos Brito, que produziu os mapas dos sítios realizando um precioso trabalho. Jaqueline Belletti e Claudia Sá, por participarem das escavações e curadoria do material. Belletti ainda foi uma interlocutora fundamental durante a análise cerâmica. Anne Rapp Py-Daniel, pelo imenso trabalho e observações atentas do contexto funerário. Silvia Cunha Lima e Val Moraes, por realizarem trabalhos primorosos de conservação e resturação das urnas. Rafael Barbi, por ser o mago dos pdf's e pela leitura de parte do texto. Angela Steward e Camile Rognat gentilmente cederam artigos ainda não publicados com resultados de suas pesquisas. Eduardo Kazuo Tamanaha, pelo auxílio na reta final.

Aos companheiros de Tefé: Alessandra, Eduardo, Marilene, Raquel e Oscar, Adriano, Juliana, Nayara, Vacão, Angela e Barbi, Mariana, Sandro, Gabi, Fernanda, Michele, Rafa Sposito, Emílio, Zé, entre tantos outros que por lá passaram e que deixaram minha vida naquela cidade mais feliz e literalmente mais saborosa.

Em São Paulo: Guilherme, Marjorie, Kazuo, Carol e Leandro, Jaq, Erê, Rodrigo, Chumbinho, Silvana, e mais outros companheiros de cursos, nos encontros pelo MAE e afora, agradeço pelas conversas que de alguma forma acabaram por influênciar esse trabalho.

Por fim, agradeço toda a família em Belo Horizonte e São João de Meriti, minha mãe Mírian, Alice, Paulo e Maíra - a pressão de vocês para finalizar esse mestrado foi fundamental. Mais uma vez ao Bernardo pelo apoio irrestrito. À Sara sou grata por me proporcionar a leveza em realizar a árdua tarefa de produzir um trabalho acadêmico. 


\section{LISTA DE FIGURAS}

Figura 1: Registro de escavações amadoras na comunidade Boa Esperança em 2001.......................14

Figura 2: Coleção de peças arqueológicas da comunidade Boa Esperança..........................................23

Figura 3: Seringueira do açaizal. Comunidade Boa Esperança, 2010.................................................26

Figura 4: Urna antropomorfa de Mapari, médio Japurá (Metraux, 1930) ............................................34

Figura 5: Mapa com a indicação dos sítios e regiões mencionados no capítulo 1...............................35

Figura 6: Cerâmicas da Fase Caiambé (Hilbert, 1968) ..........................................................................37

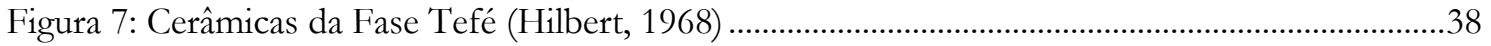

Figura 8: Cerâmicas da fase Japurá (Hilbert, 1968) ….............................................................................40

Figura 9: Materiais associados às fases Caiambé e Tefé......................................................................43

Figura 10: Fragmentos da Fase Amanã no sítio Boa Esperança..........................................................52

Figura 11: Fragmentos da Fase Pocó no sítio Boa Esperança ................................................................52

Figura 12: Fragmentos da fase Tefé no sítio Boa Esperança ................................................................52

Figura 13: Fragmentos da Fase Caiambé no sítio Boa Esperança ........................................................52

Figura 14: Esquerda: tampa de urna aflorando na comunidade São João do Ipecaçu.........................59

Figura 15: Esquerda: Urna aflorando comunidade São Pedro, Rio Japurá..........................................59

Figura 16: Prancha com planta topográfica do Sítio/Comunidade Kalafate e fotografias..................64

Figura 17: Prancha com fotografias e planta topográfica do sítio/comunidade Monte Sinai ............66

Figura 18: Levantamento não-interventivo no sítio Cacoal...............................................................67

Figura 19: Ilustração dos diferentes níveis da água em diferentes momentos do ano........................67

Figura 20: Sítio Cacoal do Amanã, planta topográfica. Marcos Brito....................................................68

Figura 21: Prancha com a distribuição dos fragmentos cerâmicos. ......................................................69

Figura 22: Diferentes etapas de escavação das unidades.....................................................................70

Figura 23: Cerâmica coletada no interior da F6.............................................................................72

Figura 24: Urna 551 fotografada antes da escavação de extensão da unidade para sua coleta ............72

Figura 25: Perfis estratigráficos do sítio Cacoal do Amanã. ...................................................................74

Figura 26: Sítio São Miguel do Cacau, planta topográfica e imagens gerais........................................75

Figura 27: Prancha com a distribuição dos fragmentos cerâmicos .......................................................76

Figura 28: Distribuição da terra preta nos diferentes níveis artificiais. ...................................................77

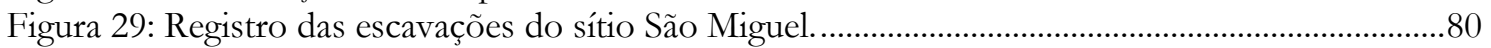

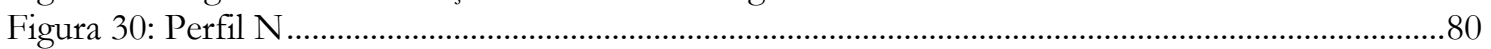

Figura 31: Distribuição da decoração a partir de amostras da Amazônia Central ...............................91

Figura 32: Da esquerda para direita, exemplos dos tipos de padrões ...............................................92

Figura 33: Imagens da derruba do caraipé verdadeira e queima das cascas por oleiras da comunidade

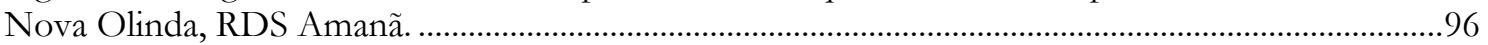

Figura 34: Exemplos de antiplásticos observados na lupa com aumento de 60x..............................98

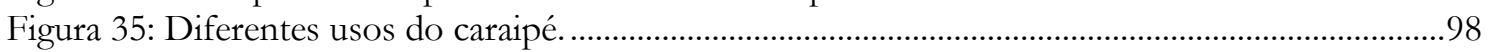

Figura 36: Fragmento de assador com variação da cor da pasta....................................................... 100

Figura 37: Exemplo dos tratamentos de superfícies aplicados nas cerâmicas de Cacaol.................. 101

Figura 38: Fragmento proveniente do nível 10-20 cm .................................................................. 102

Figura 39: Formas e acabamentos dos lábios.............................................................................. 103

Figura 40: Diferentes tipos de base ientificadas no sítio Cacoal..................................................... 104

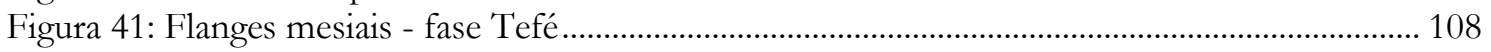

Figura 42: Flanges mesiais - Fase Caiambé .................................................................................... 108

Figura 43: Desenhos de assadores dos contextos arqueológicos da Amazônia boliviana ................ 109

Figura 44: Prancha com estauetas do sítio Cacoal. ........................................................................... 110

Figura 45: Fragmentos que apresentam diferentes técnicas aplicadas em conjunto........................ 112

Figura 46: Diferentes graus de regularidade do traço. ...................................................................... 115

Figura 47: Bordas diagnósticas da fase Caiambé ............................................................................. 116

Figura 48: Fragmentos cerâmicos exemplares do desing mais curvilíneo....................................... 117

Figura 49: Fragmentos cerâmicos exemplares do desing retilíneo.. ................................................ 117

Figura 50: Repertório gráfico das cerâmicas do sítio São Miguel. Desenhos: Laura Furquim. ....... 121

Figura 51: Exemplo de vaso com decoraçao retílinea, à esquerda detalhe do lábio inciso. ............. 121

Figura 52: Fragmentos diagnósticos do sítio São Miguel do Cacau. .................................................... 125

Figura 54: Escavação do sítio Bom Jesus do Baré. ........................................................................... 126 
Figura 55: Urna PN 516 após processo de restauração.................................................................... 127

Figura 56: Detalhe dos fragmentos da urna, com fraturas que indicam os roletes......................... 127

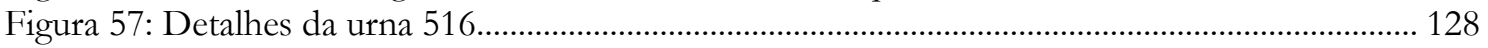

Figura 58: Escavação urna 517. Foto: Bernardo Costa ....................................................................... 129

Figura 59: Urna 518 in situ. Foto Bernardo Costa .......................................................................... 129

Figura 60: à direita vestígio ósseo e fragmento identificado durante higienização. ........................... 130

Figura 62 Unna 551 durante processo de higienização e conservação............................................... 132

Figura 63: Faixa de pintura com motivo típico Caiambé................................................................ 132

Figura 64: : Detalhes dos vestígios resinosos da urna PN 551 através de lupa binocular 60 x........ 132

Figura 65: Urna 551 após trabalho de conservação e colagem parcial.............................................. 134

Figura 66: Acima vaso remontado, provável tampa da urna......................................................... 135

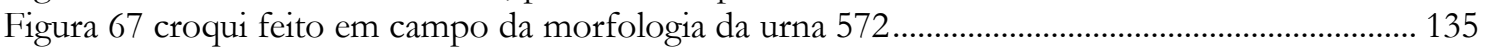

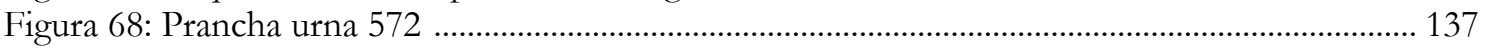

Figura 69: Acima croqui feito durante escavação.............................................................................. 138

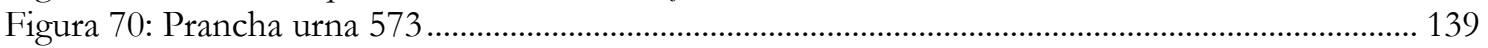

Figura 71: Morfologias reconstituídas do material cerâmico coletado no interior da urna 685 ...... 143

Figura 72: Fotos sítio Açutuba Fase mancapuru............................................................................ 150

Figura 73: Perfis de bordas com carenas, formando discretas flanges mesiais................................ 150

\section{LISTA DE GRÁFICOS}

Gráfico 1: Índice de fragmentação por nível artificial......................................................................95

Gráfico2: Índice de fragmentação por nível artificial. ........................................................................95

Gráfico 3: Frequencia de antiplásticos (agrupados) na amsotra do sítio Cacoal do Amanã ...............98

Gráfico 4: Frequencia de formas de vasos observadas nos níveis artificiais e feições..................... 103

Gráfico 5: Frequencia nos níveis artificiais das técnicas decorativas. ............................................... 112

Gráfico 6: Frequência de antiplásticos do sítio São Miguel do Cacau. .............................................. 118

\section{LISTA DE TABELAS}

Tabela 2: Síntese dos estilos da fase Caiambé.......................................................................................37

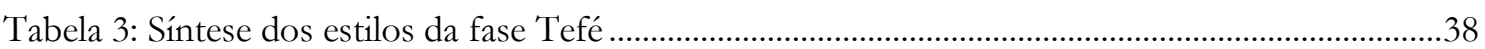

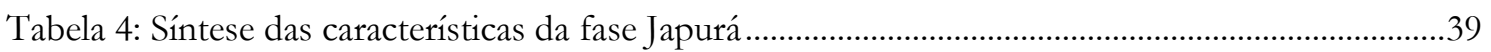

Tabela 5: Datações para a Tradição Polícroma no Lago Tefé. Extraído de Belletti, 2015.................42

Tabela 6: Datas radiocarbônicas disponíveis para o sítio Boa Esperança (Costa, 2012) .....................50

Tabela 7: Relação de sítios arqueológicos registrados e cadastrados no CNSA...................................57

Tabela 8: Sítios informados pelos moradores próximos às comunidades e áreas de uso....................59

Tabela 9: Datações radiocarbônicas disponíveis para Cacoal do Amanã............................................73

Tabela 10: Datas radiocarbônicas disponíveis para o sítio São Miguel do Cacau................................82

Tabela 11: Sítio Cacoal do Amanã: triagem da cerâmica......................................................................94

Tabela 12: Sítio São Miguel do Cacau: triagem da cerâmica.................................................................95

Tabela 13: Frequência dos tipos de queima por níveis artificiais e feições. .........................................99

Tabela 14: Frequencia dos diferentes tipos de tratamento de superfície............................................ 101

Tabela 15: Tipos de técnicas decorativas aplicadas nas cerâmicas de Cacoal................................... 111

Tabela 16: Combinações de diferentes técnicas. ............................................................................... 112

Tabela 17: Informações da amostra da análise dos elementos gráficos........................................... 114

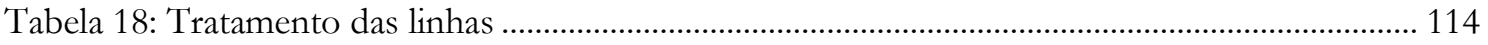

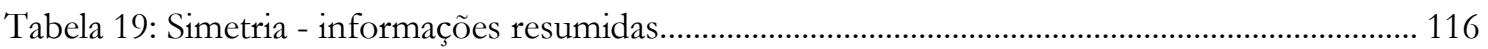

Tabela 20: Ocorrência das colorações das superfícies na amostra. .................................................. 118

Tabela 21: Ocorrência das técnicas decorativas na amostra............................................................ 120 


\section{SUMÁRIO}

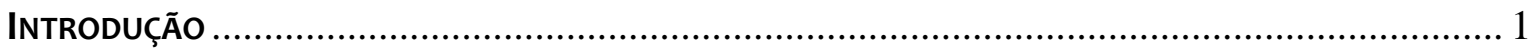

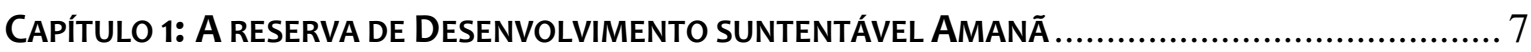

1. A Reserva: localização, características ecológicas, história e pessoas. ........................ 7

2. Arqueologia de base comunitária na RDS Amanã ............................................... 13

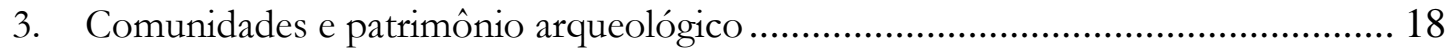

4. Paisagens de Amanã: continuidades e transformações na longa duração ................ 25

CAPítUlo 2: ARQUeologia do mÉdIo Solimões-JAPURÁ E AS QUESTÕES DA PESQUISA ................. 32

1. As primeiras informações arqueológicas e a sequência cultural no médio Solimões e

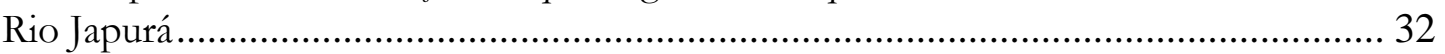

2. Arqueologia da Amazônia Central e seus modelos de história cultual.................... 43

3. Os contextos e cronologia do Lago Amanã........................................................ 49

4. As questões e objetivos da pesquisa ................................................................. 53

CAPÍTULO 3: OS SítIOS ARQUEOLÓGICOS DA RDS AMANÃ: INTERVENÇõES E OS CONTEXTOS

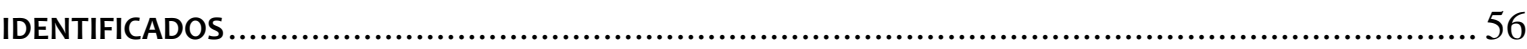

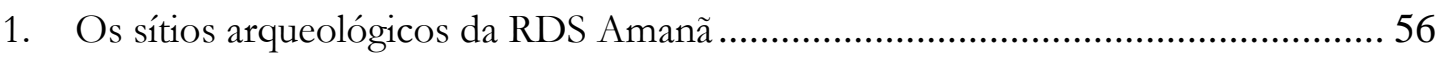

2. Metodologia de intervenção: mapeamento digital e escavação ...............................61

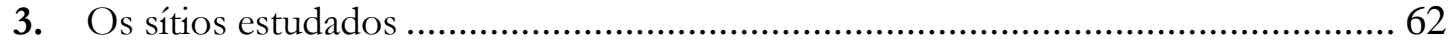

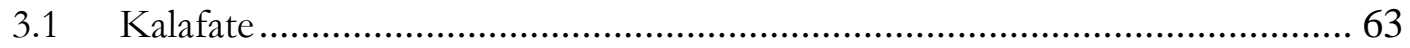

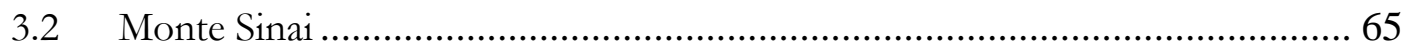

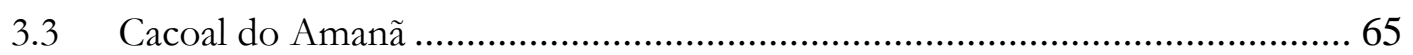

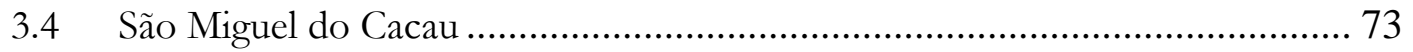

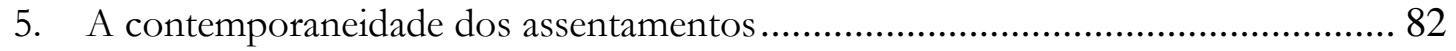

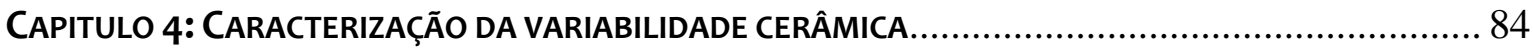

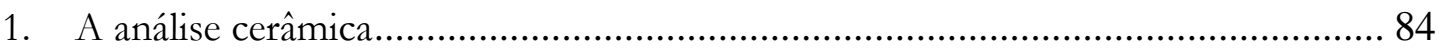

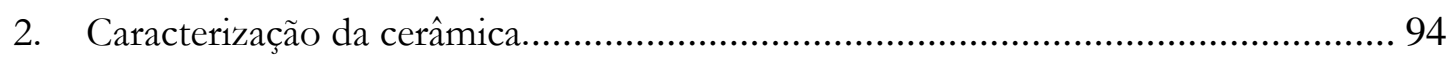

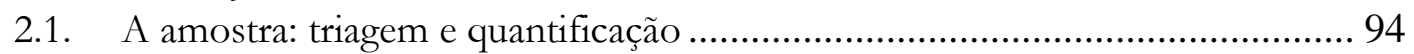

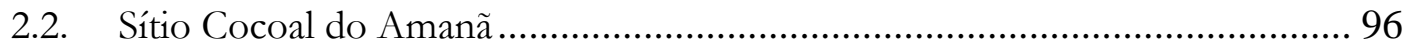

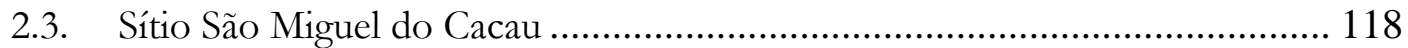

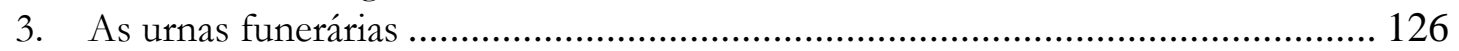

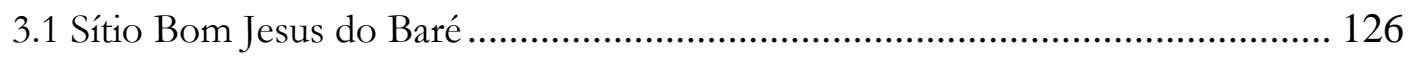

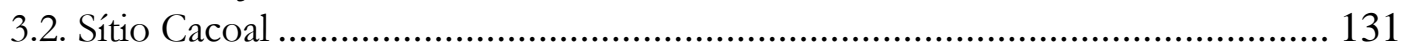

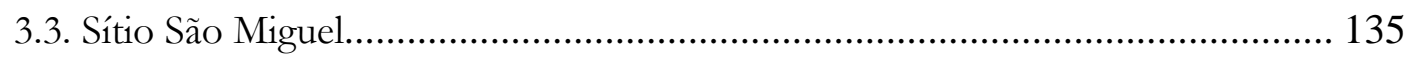

4. As cerâmicas da fase Caiambé no lago Amanã ................................................... 144

Capítulo 5: Significados da fase Caiambé no Lago Amanã no Primeiro Milênio da ERA

CRISTÃ

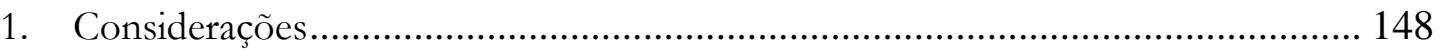

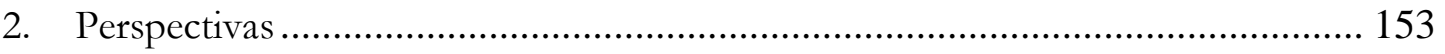

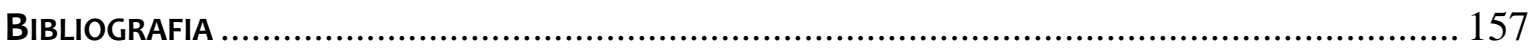


Para as pessoas que vivem e viveram às margens do Lago Amanã. 
Não é incomum, nas regiões mais antigas de Tlön, a duplicação de objetos perdidos. Duas pessoas procuram um lápis: a primeira encontra e não diz nada; a segunda encontra um segundo lápis não menos real, porém mais apropriado à sua expectativa. Esses objetos secundários chamam-se hrönir e são, ainda que desprovido de graça, um pouco mais longos.

[...]

A metódica elaboração de hrönir prestou serviços prodigiosos aos arqueólogos. Permitiu indagar e até modificar o passado, que agora não é menos plástico e menos dócil que o futuro.

Jorge Luis Borges

Tlön, uqbar, orbis tertius

Ficções 


\section{INTRODUÇÃO}

A Arqueologia vem demonstrando como a ocupação humana da Amazônia não foi um processo constante e regular ao longo do tempo e como as diversidades linguística e cultural, tão marcantes na região, podem ser vislumbradas na variabilidade cerâmica encontrada nos contextos arqueológicos. Em certa medida, a história de ocupação humana da Amazônia poderia ser compreendida como a história das paisagens, que, embora multidimensionais e com significados particulares, são verdadeiros elos entre um antigo passado indígena e o contexto de ocupação contemporânea desafiada pelas questões ambientais e de sustentabilidade.

A Reserva de Desenvolvimento Sustentável Amanã, área focal dessa pesquisa, é uma unidade de conservação localizada na porção central do Estado do Amazonas. Esta categoria de unidade de conservação é dividida em zonas de proteção integral e de uso sustentável, esta última, formada por setores políticos que são instâncias locais de organização comunitária. O modelo de gestão procura articular pesquisas científicas aos conhecimentos tradicionais, de modo a promover o desenvolvimento social e econômico das populações locais, que por sua vez, contribuem efetivamente para a manutenção da biodiversidade com práticas sustentáveis de manejo dos recursos naturais (Queiroz, 2005).

Neves (2006) destacou um problema latente nas políticas públicas aplicadas na Amazônia: a condução de estratégias para a conservação da biodiversidade está cercada pelo desconhecimento da milenar história de ocupação humana da região. Uma contradição, tendo em vista que o entendimento das modificações nas condições naturais do ambiente produzidas pelas populações ameríndias está no centro da agenda de pesquisas contemporâneas. Enquanto a ecologia histórica preocupa-se em elucidar como se dão empiricamente as relações entre humanos e natureza (Baleé, 1989), a arqueologia busca compreender os contextos históricos e sociais nos quais tais mudanças parecem se intensificar (Neves et al, 2014). A mim, parece claro que o diálogo entre a arqueologia e estratégias de conservação da biodiversidade, pode ser frutífero e harmônico, mas ainda 
pouco frequente. A RDS Amanã é a única UC na Amazônia que mantém há anos pesquisas sistemáticas neste campo de conhecimento. Esta dissertação, em última instância, busca contribuir para esta questão.

Na RDS Amanã as pesquisas arqueológicas se desenvolveram a partir de demandas dos moradores, cientes do valor científico e histórico, mas principalmente do potencial turístico do patrimônio arqueológico. Um grande objetivo subjacente à pesquisa é a elaboração de um plano de manejo comunitário do patrimônio, que garanta, em conjunto com outras áreas de conhecimento, a gestão de recursos na Reserva. Este estudo, portanto, é parte de uma demanda institucional, com objetivo de gerar informações para a conservação do patrimônio arqueológico, de modo que seus resultados subsidiem a construção do plano de gestão dessa unidade de conservação.

Sumariamente o objetivo da dissertação é contribuir para a construção de uma história cultural do Lago Amanã e a compreensão de sua antiga e intensa ocupação précolonial. Os sítios arqueológicos da região, em sua maioria, são formados por camadas de terra preta e uma grande variabilidade cerâmica, representada pela presença de três importantes tradições: Pocó-Açutuba, Borda Incisa e Polícroma. A produção de informações arqueológicas busca ainda caracterizar estes contextos, cuja profundidade cronológica é de 3.200 anos (Costa, 2012). A fase Caiambé da tradição Borda Incisa é o recorte de análise, a partir do refinamento de suas características estilísticas e contextuais, procuro compreender seus significados no quadro cronológico da Amazônia Central e suas relações com os complexos culturais anteriores e posteriores a ela. Ao lidar com a especificidade de uma fase, a noção de cultura arqueológica é essencial e denota como já consagrado na literatura, a expressão da materialidade de culturas específicas (Childe, 1957).

Os significados aos quais me refiro tratam especificamente dos aspectos cronológicos e dinâmicas sociais em uma perspectiva de longa duração. Isto é, se as ocupações da fase Caiambé seriam resultado de um desenvolvimento local, cujo estilo estaria correlacionado às cerâmicas mais antigas encontradas na região, ou de outra forma, representariam um episódio distinto sem relação necessária com as ocupações anteriores. Para tanto a proposta é melhor caracterizar os contextos e as próprias cerâmicas Caiambé, de modo a evidenciar se há ou não relações de continuidade, mudança ou ruptura entre as ocupações das diferentes tradições conhecidas em âmbito local.

A tradição Borda Incisa envolve um debate bastante intenso entre os pesquisadores por uma série de motivos, dentre os quais, por suas cerâmicas apresentarem uma grande variabilidade estilística e morfológica, devido sua ampla distribuição geográfica e sua 
associação aos contextos de terra preta (Lima, 2008). Na Amazônia Central o período correlacionado às ocupações Borda Incisa é considerado de adensamento populacional e quando as mudanças nas paisagens são mais intensas, associadas aos falantes de línguas Arawak, fruto de um processo de mudança lento relacionado às ocupações anteriores da tradição Pocó-Açutuba (Neves et al, 2014). A partir de meados de primeiro milênio da Era Cristã, a área parece abrigar um sistema regional multiétnico com circulação de cerâmicas e compartilhamento de uma mesma cosmologia baseada na ocupação de aldeias circulares (Neves, 2013: 197). Portanto, relações entre as tradições Pocó-Açutuba e Borda Incisa são interpretadas sob a premissa de uma história de continuidades culturais, expressas na sobreposição de camadas culturais nos pacotes de terra preta, na tecnologia cerâmica e formato de aldeias. Após o período de um milênio de ocorrência dessas tradições, essa dinâmica não parece ter sido a mesma quanto ao surgimento e expansão da tradição Polícroma na calha do Amazonas - que segundo os modelos atuais, foi relativamente rápida, envolveu conflitos e disputas por territórios (Moraes e Neves, 2012; Moraes, 2013).

Considerando que as cerâmicas Caiambé foram encontradas em todos os sítios escavados às margens do lago Amanã, nossa hipótese de trabalho foi que no período de sua ocorrência, aldeias contemporâneas começaram a se estabelecer. Embora aparentemente simples, com essa hipótese temos de lidar com o fato de que o registro arqueológico representa, na verdade, um palimpsesto dos resultados relevantes de interações, cuja contemporaneidade não pode ser assumida a priori, mas podem ser arqueologicamente reconhecíveis através de um quadro temporal mais amplo, como ciclos sazonais agrícolas, espaços rituais ou projetos públicos (Yaeger \& Canuto, 2000:12). E neste sentido, a formação de espaços específicos para a deposição de grandes urnas funerárias e rituais no lago Amanã, ou a formação dos extensos castanhais característicos da região, podem ser compreendidos respectivamente, como lugares de memória e constituição de uma paisagem, cuja origem remonta às ocupações Borda Incisa.

Compreendo o presente estudo como parte de um movimento de pesquisas de revisão, que busca oferecer refinamento das cronologias de ocupação, relativizando as relações entre manejo de paisagens, dinâmicas sociais, e da produção e circulação de objetos. Para identificar a variabilidade crono-tipológica do material cerâmico, produzindo um perfil detalhado dos aspectos tecnológicos para o reconhecimento de estilos particulares e sua transformação ao longo da sequência estratigráfica, o tratamento dispensado ao material cerâmico buscou-se não hierarquizar os aspectos de manufatura, morfologia e decoração, o que tem sua base em uma noção de tecnologia como um fenômeno onde as dimensões 
materiais e simbólicas encontram-se entrelaçadas (Silva, 2002:131), e, portanto, inerentemente dinâmico, relacionado às circunstâncias ecológicas e às escolhas individuais, mas sempre socialmente significativas.

Para além dessa arqueologia baseada no estudo da cultura material e registro, entendo que a construção de uma história cultural de Amanã deverá envolver também as comunidades contemporâneas, principalmente por dois motivos. Primeiro este estudo foi desenvolvido no âmbito de pesquisas de base comunitária (Atalay, 2008), e essas comunidades atuais, quase de forma absoluta, estão assentadas sobre os sítios arqueológicos, aqui considerados, como um contingente dos diferentes usos e grupos humanos no passado, mas também das ações contemporâneas.

Para as pessoas que ocupam esses lugares hoje, os vestígios materiais apontam para formas de ocupação prévias distintas delas. As relações das populações atuais com o patrimônio arqueológico expressam modos locais de pensar as categorias sociais da região. Embora em cada comunidade, e a nível individual, seja possível falar em diferentes formas de se reconhecer, seja como "arigó", "amazonense" ou "índio", há uma maneira semelhante de se relacionar com os lugares e paisagens do lago Amanã, marcada por uma conexão entre a dimensão antropogênica do ambiente e os regimes locais de apropriação, nos quais há uma lógica profundamente associada às dinâmicas do parentesco regional (Lima, 2005).

Viver na RDS Amanã exige o domínio de técnicas de engajamento com o ambiente, que poderiam inicialmente ser pensadas como "tradicionais" ou "ancestrais", mas sabemos que as práticas ribeirinhas não provêm diretamente de um legado do passado índigena, não são transmitidas "de geração em geração" como conhecimentos "prontos". São habilidades construídas através da "improvisação de diversas capacidades e recursos", no engajamento com o ambiente e nas práticas de imitação e recomposição de habilidades (Harris, 2005; Ingold, 2000).

Ainda que os moradores não tracem uma relação necessária entre seu mundo vivido e uma continuidade histórica dessas habilidades, e que tão pouco a pretensão seja simplicar as complexas estratégias de elaboração dessas habilidades, quando olhamos através de uma perspectiva de longa duração, as comunidades atuais e suas áreas de uso estão sobrepostas aos locais que no passado foram usados durante as ocupações da fase Caiambé, e mesmo antes durante as ocupações Pocó. Considerar que essas escolhas não são aleatórias é o primeiro passo para compreender as relações entre as ocupações de Amanã, já que elas nos oferecem indícios de escolhas culturais por espaços previamente antropizados, sugerindo 
processos de continuidade no manejo de espécies vegetais (Machado, 2012, Furquim e Rognant, 2014).

Talvez seja a Arqueologia a área de conhecimento que melhor permita uma visão geral da paisagem com profunidade cronológica e estrutural. Nesse sentido, embora paisagem não se configure como uma ferramenta analítica neste trabalho, ela é um conceito teórico subjacente, como uma chave para o entendimento da experiência e ação humana sobre o ambiente (Knapp e Ashmore, 1999). O que me parece interessante, é vislumbrar a historicidade das paisagens de hoje, considerando que o lago Amanã durante o primeiro milênio da Era Cristã parece ter sido um lugar persistente e significativo para as ocupações da Tradição Borda Incisa que viveram na região do médio Amazonas e baixo Japurá.

\section{Estrutura da dissertação}

O capítulo 1 apresenta a área de pesquisa, com a caracterização ecológica e histórica da RDS Amanã, e o desenvlvimento das pesquisas arqueológicas e seus objetivos. Procuro situar a pesquisa no espectro de arqueologias comunitárias (Community Archaeology), já que a reflexão posterior é resultado de atividades desenvolvidas entre as comunidades participantes e visaram traçar um perfil de como os moradores interagem com o patrimônio através de uma breve etnografia, com a perspectiva de subsidiar ações específicas de gestão comunitária. Neste capítulo, sugiro que as ocupações recentes da RDS Amanã remetem a processos de continuidade marcados nas paisagens, e exploro a maneira como os moradores percebem e significam os vestígios arqueológicos, a partir de relações que envolvem processos de autodefinições, bem como a maneira como percebem a história local.

No capítulo 2 é oferecida uma contextualização das informações arqueológicas disponíveis, com um breve histórico das pesquisas de forma mais ampla sobre a região do médio Solimões e rio Japurá, de modo a expor a sequência cultural conhecida para a região. Em seguida, são expostos os dados disponíveis para outras áreas da Amazônia central, um quadro cronológico construído através das informações geradas pelo Projeto Amazônia Central que ofereceu uma revisão e construção de novos modelos de ocupação da região, relacionados a dois principais troncos linguísticos: Arawak e Tupi. Por fm, as informações arqueológicas do Lago Amanã serão apresentadas de modo detalhado, para evidenciar as singularidades dos contextos locais. Este olhar macrorregional é importante para contextualizar as questões e hipóteses de trabalho apresentadas no fim do capítulo. 
O capítulo 3 é reservado aos sítios arqueológicos da RDS Amanã, apresentando resultados da continuidade do levantamento em outros setores da Reserva e das intervenções em quatro sítios situados no lago Amanã. Tratamos dos contextos dos sítios cerâmicos a céu aberto:

i) Cacoal do Amanã e São Miguel do Cacau, ambos de habitação que apresentam camadas de terra preta e depósitos claramente domésticos, além de abrigarem setores específicos para a deposição de urnas.

ii) Monte Sinai e Kalafate, sítios de pequenas dimensões, compostos basicamente por urnas depositadas no solo argiloso natural da região, ao que parece, exclusivamente funerários.

Serão expostas as metodologias aplicadas nas intervenções para o mapeamento e escavação dos sítios/comunidades e os resultados dessas investidas de campo. Estes contextos em Amanã foram relacionados à fase Caiambé (Costa et al, 2012), e considero importante ampliar as discussões sobre funcionalidades distintas desses sítios, bem como as datações obtidas, que indicam a contemporaneidade dos assentamentos $\mathrm{O}$ principal objetivo do capítulo é expor as informações contextuais que podem caracterizar a fase Caiambé.

O capítulo 4 é dedicado à caracterização da variabilidade das cerâmicas dos sítios Cacoal e São Miguel do Cacau. Primeiro é exposta detalhadamente a metodologia aplicada na análise, em seguida a amostra e por fim, os resultados alcançados, visando traçar um perfil dos aspectos tecnológicos observados no material. Na parte final estão reunidas as informações sobre as urnas funerárias com objetivo de expandir a caracterização das cerâmicas da fase Caiambé a partir de objetos inteiros e um contexto de uso e deposição específicos.

O $5^{\circ}$ e ultimo capítulo é uma síntese sobre a fase Caiambé e seus significados históricos e sociais na história de ocupação humana na RDS Amanã. Nesse sentido, dois aspectos são importantes. O primeiro é considerar sua ocorrência, duração e singularidades no âmbito local, o que envolve os dados apresentados nos capítulos anteriores (3 e 4) e o diálogo com as informações disponíveis em escala macrorregional para Amazônia Central. O segundo aspecto, que é fundamental no contexto de uma unidade de conservação de uso sustentável, é considerar que durante a fase Caiambé, uma paisagem simbólica e cultural parece estar se formando, índice de um modo específico de ocupação relacionado a populações Arawak, que deixaram marcas profundas o suficiente para influenciar as estratégias contemporâneas de manejo e sustentabilidade. 


\section{A Reserva de Desenvolvimento Sustentável Amanã}

1. A Reserva: localização, características ecológicas, história e pessoas.

A região do médio Solimões e baixo Japurá é um verdadeiro mosaico de áreas protegidas $^{1}$, se configurando como uma zona importante nas estratégias e políticas de conservação da biodiversidade amazônica. Reservas de Desenvolvimento Sustentável $(\mathrm{RDS})^{2}$ buscam promover a conservação da biodiversidade de uma determinada área, assegurando os meios necessários para a manutenção de populações tradicionais que nela vivem (Queiroz e Peralta, 2005). As estratégias de gestão têm como base a combinação dos conhecimentos científico e tradicional, com a valorização das técnicas de manejo do ambiente desenvolvido ao longo de gerações por essas populações adaptadas às condições ecológicas locais (Ayres et al., 1996).

A RDS Amanã foi criada em 1998 no âmbito de uma abordagem integrativa e bioregional de conservação do Bioma Amazônia (Queiroz, 2005), sendo um elo entre a RDS Mamirauá, o Parque Nacional do Jaú e a Reserva Extrativista do Rio Unini, que junto à diversas terras índigenas compõem o Corredor Ecológico da Amazônia Central (Figura 1). Com uma extensão territorial de 2.313.000 hectares, sua área abrange parte dos municípios de Barcelos, Maraã, Coari e Codajás, na porção central do Estado do Amazonas, localizada ao norte do rio Solimões no interflúvio do rio Negro e rio Japurá $\left(01^{\circ} 35^{\prime} \mathrm{S}, 62^{\circ} 44^{\prime} \mathrm{W}\right.$ e $\left.03^{\circ} 16^{\prime} \mathrm{S}, 65^{\circ} 23^{\prime} \mathrm{W}\right)$.

\footnotetext{
1 O termo 'áreas protegidas' foi definido no Plano Nacional de Áreas Protegidas (PNAP) pelo Decreto $\mathrm{n}^{\circ}$ 5758 de 13 de abril de 2006 e inclui as UCs de uso sustentável e proteção integral, as TIs e as terras ocupadas por remanescentes de quilombos

${ }^{2}$ Unidades de Conservação (UC) são territórios geridos pelo Sistema Nacional de Unidades de Conservação (SNUC) que privilegia um modelo ecossistêmico de manutenção da natureza buscando abarcar em alguma medida sua complexidade, em detrimento de uma visão fragmentada e isolada dos recursos naturais (Braga e Maciel, 2011:152; Machado et al, 2013). As UCs se dividem entre aquelas de proteção integral e as de uso sustentável (SNUC - art. $7^{\circ}$ da Lei no 9.985 , de 18 de julho de 2000). As primeiras objetivam preservar a natureza, mas com uso indireto dos recursos naturais; as de uso sustentável procuram compatibilizar conservação com o uso racional e sustentável de parcela dos recursos naturais. Foi no médio Solimões, com a RDS Mamirauá a primeira experiência do tipo, criada em 1996 pelo Estado do Amazonas, sendo posteriormente uma categoria incorporada ao SNUC, como reconhecimento do modelo para a conservação da natureza e do modo de existência de populações tradicionais (IDSM, 2010).
} 


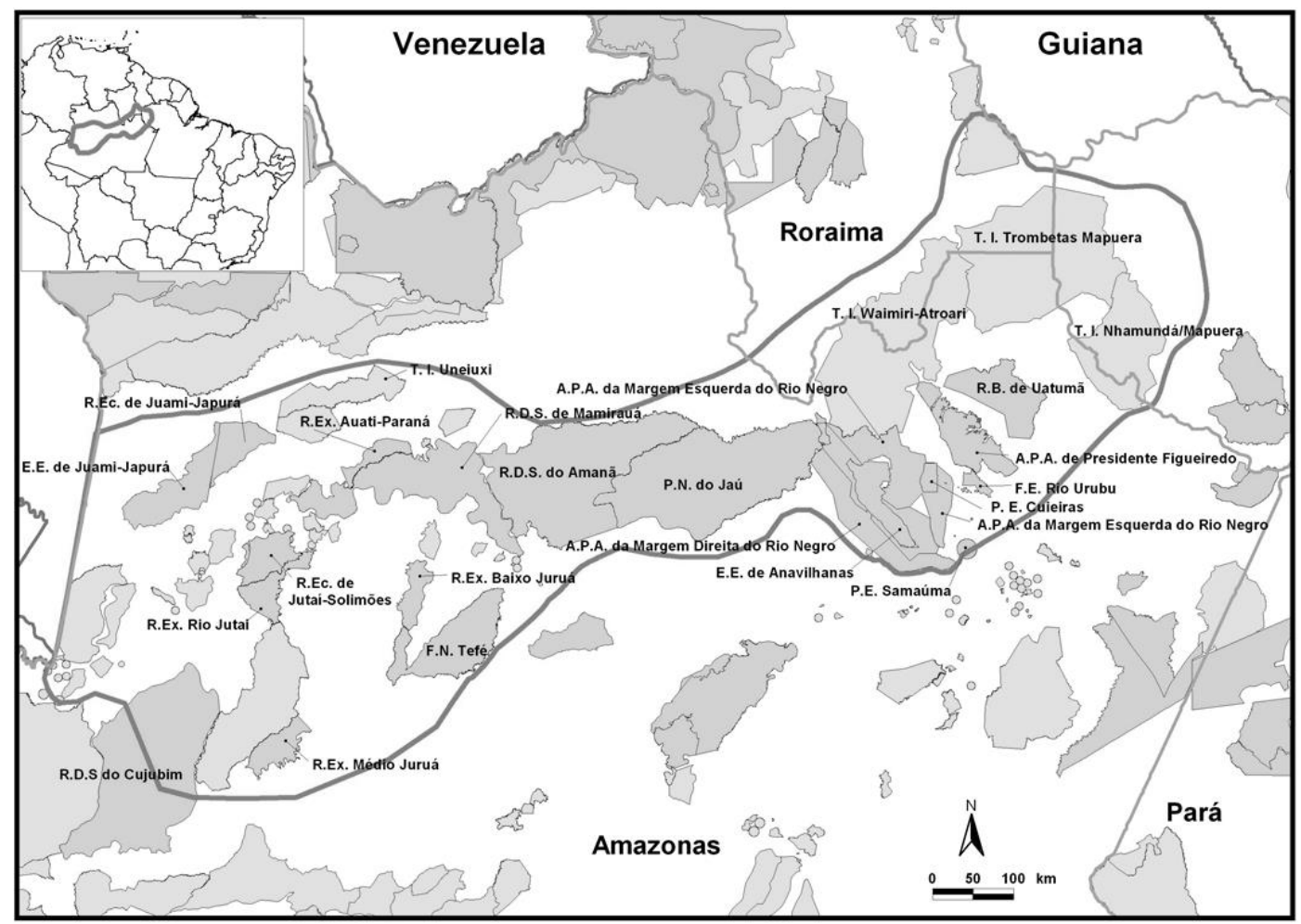

Mapa 1: Localização da RDS Amanã no Corredor Ecológico da Amazônia Central

Amanã é considerada uma área síntese do Bioma Amazônia, por apresentar seus principais ambientes (Queiroz et al, 2008). A localização entre bacias de águas pretas e brancas e seus terrenos de origem geológica terciária e quartenária, garantem do ponto de vista biológico, alta biodiversidade. A maior parte da reserva é formada por florestas de terra firme que dominam principalmente suas porções leste e norte-nordeste, com trechos de campinarana. Ainda há ambientes de paleovárzea, igapó e matas de várzea nas porções sul e sudoeste, de formações mais recentes do Holoceno, são funcionais, anualmente alagadas por muitos metros por águas brancas ricas em sedimentos e nutrientes do Japurá e Solimões.

O lago Amanã, que dá nome a Reserva, possui $44 \mathrm{~km}$ de comprimento e $3 \mathrm{~km}$ de largura, é considerado um paleo-canal do rio Japurá, sendo um ambiente de paleo-várzea ${ }^{3}$,

\footnotetext{
${ }^{3}$ Em recente re-classificação dos tipos de várzea na Amazônia, Junk et al. (2011) propõem que a planície de inundação de paleo-várzeas deve ser classificada como uma categoria distinta de várzea. A categoria de paleovárzea foi descrita pela primeira vez por Irion (1976) e tem sido referida de diversas formas, tais como várzea do Pleistoceno (Irion 1976, 1978; Klammer 1984), várzeas abandonadas (Salo et al., 1986) ou várzea antiga (Ayres, 1993). São formações do Pleistoceno, quando, provavelmente devido ao nível do mar, as várzeas amazônicas eram muito mais extensas do que são hoje (Irion 1976, 1984; Klammer 1984). Florestas de paleovárzea estão localizadas em depósitos aluviais andinos abandonadas pelos rios de água branca. São inundadas por pequenos e intermediários corpos de água preta, que conferem aos seus substratos menor fertilidade que os da várzea, mas muito mais férteis que ambientes de igapó (Irion 1978; Schubart 1983)
} 


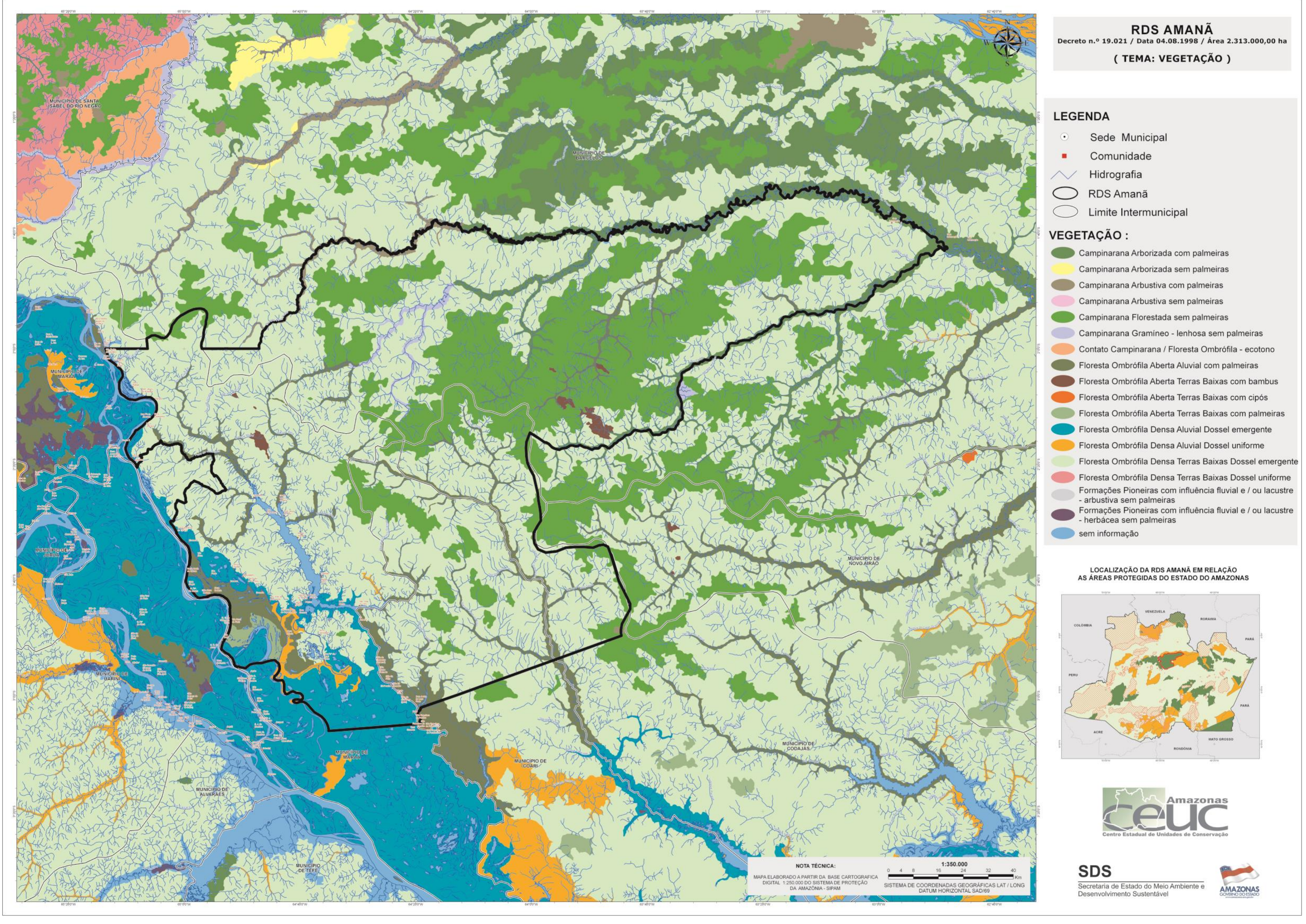

Mapa 2: A RDS Amanã e sua vegetacão. Fonte: Centro Estadual de Unidades de Conservação. 
com fisionomia muito similar à de terra-firme. Sua porção superior é dominada por águas pretas, especialmente por um aporte grande dos tributários locais, quase todos, igarapés originados nas terras com matas altas de terra firme, enquanto sua parte inferior tem forte influência das águas mistas do Japurá e águas brancas do Solimões (Queiroz et al, 2008).Um dos fatores mais importantes na distribuição, comportamento e diversidade de formas de vida presentes na reserva é a variação sazonal no nível da água causada pelo padrão anual do regime de inundação dos rios e lagos da região. No período da cheia, forma-se uma área de floresta inundada (igapó), que compreende uma pequena faixa ao longo do perímetro do lago Amanã, cuja variação anual do nível de água é em torno de 9 a 10 metros. Estas áreas são especialmente importantes para a ocupação humana já que se contituem como ilhas de recursos pesqueiros durante o período de enchente (Moran, 1990).

Amanã teve um papel importante no processo recente de ocupação humana na região do médio Solimões, por ter sido utilizado como via de acesso aos cursos hídricos para o rio Negros (Alencar, 2006). Essa importância também está registrada nas fontes etno-históricas que destacam as redes de trocas existentes no século XVII, sendo Amanã um provável circuito conhecido pelos Cauauri (ou Caburicena), que viviam no interflúvio Negro-Japurá (Porro, 1995) e pelos Manao (Metraux, 1940:5). Um breve levantamento de fontes demonstra a diversidade étnica presente no rio Japurá no inicio da colonização e seu paulatino desaparecimento, marcado por fugas, escravidão, ondas migratórias entre o Uaupés e o Caquetá, além de processos de pacificação (Faulhaber,1992). Viajantes naturalistas e etnólogos documentaram a predominância do povo Miranha no Japurá e a dispersão causada pela compra e venda de escravos, principalmente crianças, durante o século XIX (Spix \& Martius, 1981 [1831]; Marcoy, 1875 [1862]; Bates, 2009[1863]; KochGrünberg, 2005 [1909]; Tastevin, 2008 [1928]). ${ }^{4}$ Os deslocamentos forçados dos povos indígenas devido à demanda de mão de obra para os seringais e a exploração das áreas

\footnotetext{
${ }^{4}$ Na região do Lago Amanã no ínicio do século XX, a presença indígena enfatizada é dos Mura Marcoy (1875 [1862]) afirma que, no início do século XVII, os Mura habitavam a margem direita do Amazonas, próximo aos lagos e igarapés entre os rios Tefé e Madeira. Lima (1992) destaca que no século XVIII os Mura eram apontados como um dos motivos da escassez de comida na região de Tefé, por suas investidas contra assentamentos dos colonizadores da região. Essa situação se transforma quando são "pacificados" (Baena, 1888: 328). Ainda sim, no início do século XX, Tastevin (2005 [1928]) relata a presença Mura no lago Urini, afirmando que seus remanescentes teriam sido expulsos da região do Amanã quando os "civilizados" ali chegaram à procura de produtos extrativos. Esse grupo teria, então, iniciado um processo de migração intensiva, mudando de lugar em lugar até se estabelecer no paraná do Aiucá, próximo ao Solimões
} 
centrais de terra firme, onde alguns povos indígenas haviam se refugiado após o primeiro momento da ocupação colonial, permitiu contatos desastrosos.

Na segunda metade do século XIX, a maior procura pela borracha aumentou a demanda de mão de obra das populações indígenas pelos seringalistas e caucheiros. A violência foi usada de maneira recorrente, através de diversos métodos para garantir o recrutamento e a permanência dos indígenas no trabalho das frentes da exploração da borracha (Koch-Grünberg, 2005 [1909]; Taussig, 1993; Weinstein, 1993). No mesmo período, iniciou-se um processo migratório em larga escala, no qual populações de camponeses do Nordeste se deslocaram para a Amazônia, sendo, mais tarde, absorvidos pela empresa seringalista, na qual eram submetidos a tratamento similar àquele reservado aos indígenas (Oliveira Filho, 1979).

A região das RDS’s Mamirauá e Amanã que abrigava uma população indígena marcada por um intenso processo de colonização, com a decadência da economia gomífera, vive um novo fluxo migratório nas primeirs décadas do século XX. Seringueiros começaram a descer os rios em busca de lugares para se estabelecer, grande parte se dirigiu para as áreas de várzea do médio Solimões, do Japurá e Purus, conhecidas pelos recursos piscosos e pela presença de outros produtos extrativos com valor de mercado. No lago Amanã não há registro de formação de assentamentos fixos, mas um padrão de ocupação humana caracterizado pela residência dispersa de famílias e pequenos núcleos de povoamento localizados em áreas de maior facilidade de comercialização de produtos. Essa dinâmica de ocupação da área se relaciona ao modo de exploração econômica da região, cuja vinculação dos trabalhadores aos patrões pelo sistema de aviamento, imputava intensa mobilidade para a exploração dos recursos extravistas. O território foi ocupado e construído a partir das ações dos trabalhadores que se deslocavam por amplas áreas em busca da sorva e do leite de maçaranduba, em longas expedições entre sistemas fluviais do Rio Japurá e o Rio Negro. Em suma, o tipo de exploração econômica refletiu sobre o processo demográfico (Alencar, 2007).

A partir dos anos 1960, com as ações da Igreja Católica através da Prelazia de Tefé, que visavam à melhoria das condições de vida da população ribeirinha, as famílias foram incentivadas a formar comunidades e a realizar outras atividades produtivas além da extração, como a agricultura e o cultivo de frutíferas. Também foram estimuladas a fazer a reserva de lagos situados no território de seus assentamentos para manejar os recursos pesqueiros (Peralta, 2012). Alencar (2007) observa que os grupos sociais que se formaram em Amanã estavam preocupados em controlar os territórios e o acesso aos recursos 
naturais. Essa preocupação era determinante na escolha do local para construir os povoados, geralmente à entrada de igarapés de acesso aos seringais e castanhais, ou próximos aos lagos piscosos. Apenas nos anos 1980 foram registrados grandes povoados associados ao desenvolvimento de uma atividade econômica centrada na agricultura e na criação de animais. Já nos anos 1990, com a criação da Reserva de Desenvolvimento Sustentável Amanã, houve o reforço do modelo de organização comunitária instituído pelo MEB e o desenvolvimento de ações preservacionistas de recursos naturais.

É neste período também que a região do médio Solimões começa a passar por um intenso processo de reafirmação da condição indígena por parte de seus habitantes. Isto pode ser vislumbrado pelo número de territórios homologados, 21 terras índigenas, dentre elas a TI Méria, uma dos primeiros territórios reconhecidos no país. Atualmente, 43 comunidades dos 261 assentamentos nas RDS Mamirauá e Amanã estão em processo de reivindicação de identidade indígena (Souza, 2012; Santo, 2014). Residir em áreas protegidas implica no acesso a políticas públicas diversas, nas unidades de conservação as políticas estão voltadas para programas de geração de renda e alternativas econômicas sustentáveis para minimizar o impacto social sobre a biodiversidade. Já as terras indígenas são foco de politicas públicas diferenciadas, especialmente nas áreas da saúde e educação (Santos e Souza, 2011; Souza, 2010).

Os moradores da RDS Amanã se identificam ou são classificados, portanto, segundo as categorias de ribeirinho, caboclo, arigó e indígena. A população atual é de aproximadamente 3.860 pessoas dispostas em cerca de oitenta assentamentos (IDSM, 2011), distribuídas em uma zona de uso sustentável, organizada em 10 setores políticos: Amanã 1, Amanã2, Castanho, Coraci, São José, Caruara, Joacaca, Tijuaca, Unini e CuiuCuiu (Portaria SDS no 70 de 23/04/2014). Esses setores são instâncias locais de organização política que concentram as demandas dos moradores, organizados por sua vez, em comunidades. A organização em comunidades - que passou a ser reconhecida por instituições governamentais para efeito de acesso às políticas públicas a partir da década de 1980, foi incentivada durante a criação da Reserva, uma vez que o uso dos recursos naturais possuia relações com a organização dos grupos locais. O termo comunidade não é tratado apenas como assentamento, mas denota o sentido de responsabilidade comunal de decisões políticas.

Os meios de subsistência e produção dos moradores se baseiam nas combinações de atividades de pesca, extrativismo e agricultura, sendo esta última, a atividade predominante e principal das economias domésticas, caracterizada como sazonal na várzea 
ao longo do Rio Japurá, e permanente na terra firme (paleo-várzea) em torno do lago Amanã. A caça, embora bastante praticada, está mais ligada à subsistência.

\section{Arqueologia de base comunitária na RDS Amanã}

No contexto político regional o conceito de população tradicional é caro para as políticas de conservação da biodiversidade (Carneiro da Cunha, 2009) tal como o "ressurgimento" da condição indígena é um fenômeno sociológico relevante no médio Solimões (Oliveira, 2012; Santos, 2014; Lima, Oliveira e Santos, 2011). Segundo Santos (2014), discussões anteriores a respeito dos indígenas emergentes na região estão pautadas em torno de dois princípios explicativos: 1) uma reação às políticas de conservação; e/ou 2) uma forma de acessar direitos diferenciados. Qualquer projeto arqueológico na região lida direta ou indiretamente como essas questões e suas possíveis tensões ${ }^{5}$, principalmente porque, fazer arqueologia na Amazônia, é fazer história indígena (Neves, 2007). Não por acaso, para a grande maioria dos moradores de Amanã, arqueologia é uma disciplina que trata exclusivamente da "história dos índios".

Portanto, considerando que a construção de conhecimento sobre o passado deve ser realizada de modo dinâmico e dialético em relação ao presente (Silva et al, 2011:37) e que, desse modo, o passado é altamente relevante para inúmeras situações sociais e políticas (Meskell, 2009), frequentemente projetos arqueológicos envolvem diferentes grupos de interesse sendo necessário estabelecer o envolvimento desses diferentes grupos nas questões relativas à pesquisa e gestão do patrimônio cultural (Atalay, 2010:421; 2012; Colwell-Chanthaphonh \& Fergunson, 2008; Marshall 2002; Moser et al, 2002:220; Tully 2007).

Apesar da variedade de termos para descrever pesquisas de base comunitária - ou mesmo a variação de nomenclaturas para um movimento que se preocupa com a relação entre comunidade locais e pesquisa arqueológica (como as arqueologias pública, indígena, colaborativa, comunitária) - essas iniciativas se encontram em um ponto: são projetos orientados para as comunidades, desenvolvidos com seus membros para lidar com interesses e necessidades que eles identificam (Atalay, 2010:419).

\footnotetext{
${ }^{5}$ Algo evidente nas dinâmicas dos processos de reinvidicação de TI's na região é que elas tendem a potencializar conflitos em nível local, ou seja, disputas entre grupos de parentes e moradores de uma mesma área. "A autonomia dos indígenas em relação ao uso de suas TIs muitas vezes é entendida como uma forma de "inimputabilidade" em relação à legislação ambiental. No caso dos indígenas em TIs reivindicadas, a questão se torna mais séria quando estes passam a exigir usufruto exclusivo de áreas antes compartilhadas com comunidades de vizinhos e parentes" (Santos, 2014:76)
} 
As pesquisas arqueológicas na Reserva Amanã se iniciaram a partir de uma demanda local para o aproveitamento turístico do patrimônio arqueológico, quando moradores da comunidade Boa Esperança em 2001 relataram a preocupação com a destruição de urnas devido intempéries naturais e outras intervenções (Figura 7), demonstrando o interesse de realização de pesquisas científicas:

\begin{abstract}
“Os moradores estão cientes do potencial valor histórico dos artefatos, e estão ansiosos para ter alguma orientação de especialistas. Mas também acham que as urnas poderiam ter valor para o turismo, e talvez valor como "tesouro perdido," fatos que talvez estejam motivando escavações destrutivas. Eu enfatizei a importância de deixar as urnas intactas, e guardar todos os artefatos achados sem realizar mais escavações amadoras, até que uma equipe especializada possa realizar estudos. Mas os moradores estão um pouco ansiosos e fartos de esperar: afirmam que o Projeto Amanã já tentou atrair arqueólogos há algum tempo sem sucesso. É possível que continuem escavações de curiosidade até que uma equipe profissional faça alguma intervenção. Espera-se que o IPHAN, em colaboração com o Projeto Amanã, possa registrar o sitio, realizar uma avaliação preliminar, e dar uma orientação para os moradores" (Shepard, 2001).
\end{abstract}

A partir da colaboração entre pesquisadores da Universidade de São Paulo, Universidade Federal de Minas Gerais e do IDSM e moradores da comunidade (Lima et al, 2006), a pesquisa arqueológica se iniciou com seguintes objetivos: i) a produção de informações arqueológicas, identificando as antigas ocupações, estabelecer uma cronologia para região e sua inserção na história pré-colonial na Amazônia central; e ii) a elaboração de um plano de manejo comunitário do patrimônio arqueológico, visando oferecer aos moradores mais uma alternativa de uso sustentado de um recurso não-renovável. De um modo geral, além do caráter básico de caracterização dos contextos arqueológicos, as pesquisas buscam articular educação e Foto: Glen Shepard.

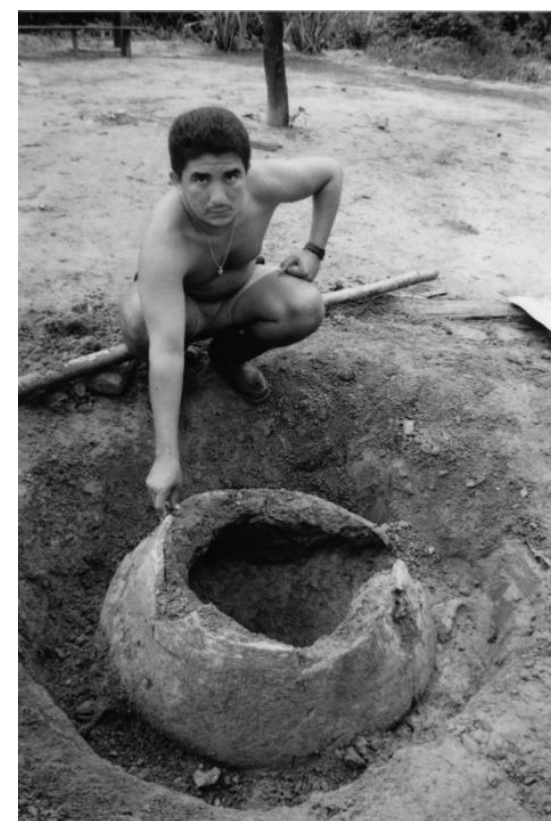

Figura 1: Registro de escavações amadoras na comunidade Boa Esperança em 2001. conservação em um mesmo conjunto de ações.

Esta pesquisa especificamente, está concentradas em dois setores da RDS Amanã, que compreende o lago (Amanã 1 e 2), envolvendo diretamente seis comunidades: Boa Esperança, Bom Jesus do Baré, Ubim, Kalafate, São Miguel do Cacau e Monte Sinai. Silva (2009; 2011) destaca que devido contextos os mais variados, arqueologias comunitárias são desenvolvidas com alguma flexibilidade em termos metodológicos, ainda sim, algumas estratégias são comuns nesses projetos que buscam o engajamento crítico das comunidades 
locais e sua interação durante o processo de pesquisa (Moser et. al. 2002; Tully,2007). Na prática, em grande medida, esta pesquisa foi condicionada às circunstâncias oferecidas pela a instituição gestora da Reserva, o Instituto Mamirauá, baseada no caráter participativo das ações de gestão e pesquisa, como prescrito na própria concepção desse tipo de unidade de conservação (Queiroz, 2008). As ações que propomos, mais que considerar a importância das relações entre distintas comunidades e o patrimônio arqueológico, visando, sobretudo sua socialização, objetivaram envolver tais comunidades nos processos de pesquisa e gestão deste patrimônio, e alinham-se às pespectivas das arqueologias de base comunitária (Atalay, 2008). Algumas ações foram:

1) interação entre pesquisadores e a comunidade local, com presença constante na área ao longo da pesquisa, promovendo a comunicação frequente sobre os resultados obtidos e a comunidade inteirada sobre os procedimentos e andamento da pesquisa. O Instituto Mamirauá estabele como prioritário, na maioria das vezes, que os pesquisadores residam na região durante o período da pesquisa.

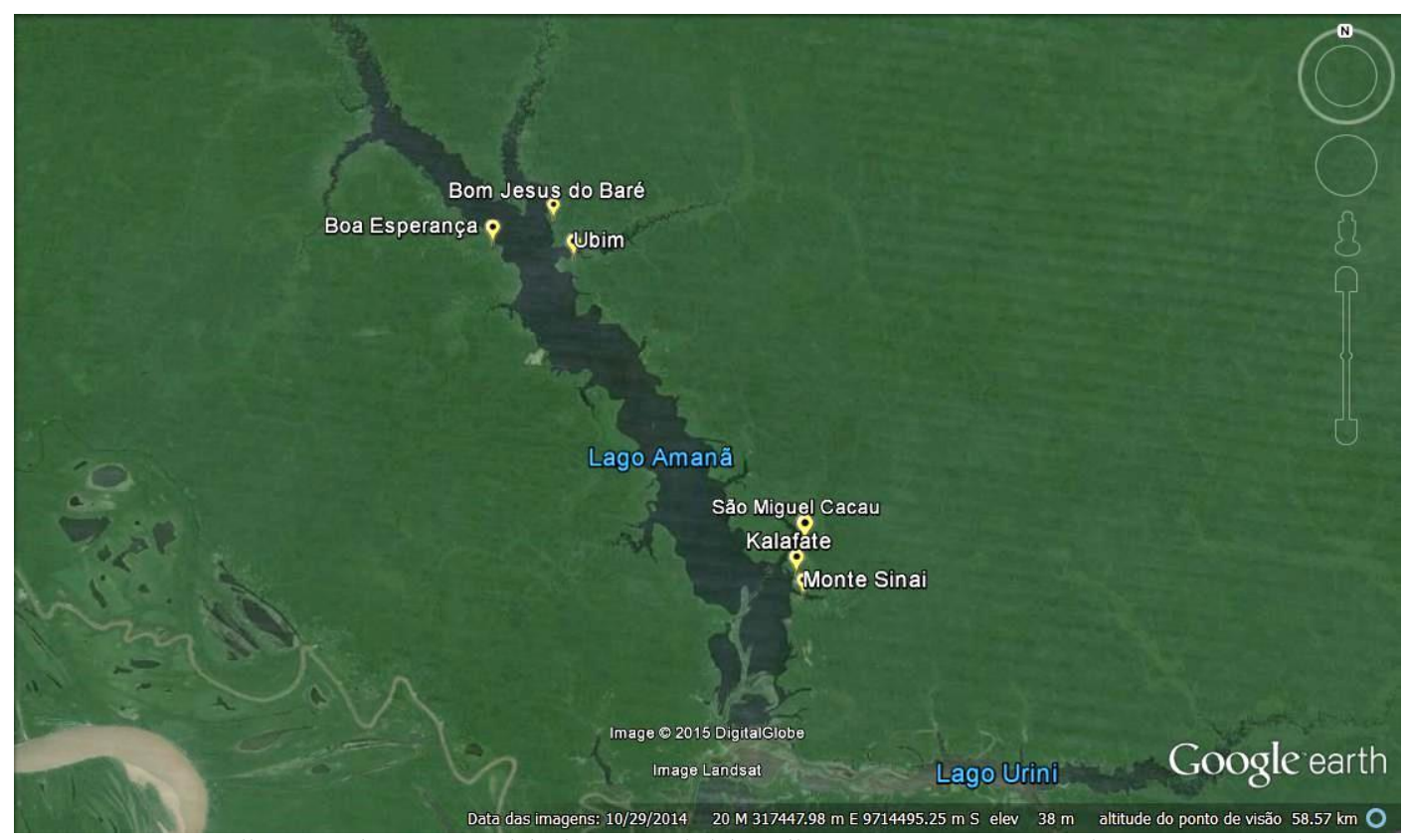

Mapa 3: Localização das comunidades envolvidas diretamente nas pequisas arqueológicas. Setores Amanã 1 e Amanã 2.

2) Os moradores tiveram e ainda possuem fácil acesso aos vestígios arqueológicos coletados, principalmente porque houve a possibilidade de manter os materiais escavados na própria cidade de Tefé em condições adequadas de salvaguarda. Ainda no "laboratório de selva", localizado na Reseerva Amanã, puderam ser realizadas etapas de análises cerâmicas com a participação de moradores (Gomes, 2011). 
3) As comunidades foram consultadas previamente sobre os procedimentos de campo e sempre incentivadas a colaborarem em todo o processo da pesquisa. As etapas de levantamento foram realizadas com a participação comunitária ${ }^{6}$, baseada nas informações orais, que em conjunto com observações sobre processos pósdeposicionais naturais (como chuvas e inundações sazonais) e culturais (como o uso atual do espaço, intervenções para construções, limpeza de quintais, roças, trilhas, lixeiras, etc), e informações sobre composição e densidade de vestígios arqueológicos, foram consideradas em conjunto, para elaboração de uma lista de relevância dos sítios (Costa, 2009; 2012). As intervenções arqueológicas foram realizadas com a anuência e participação comunitária com objetivo de mapear o sítio arqueológico e a comunidade, além de coletar amostras de cultura material e outros vestígios. As ações sobre o terreno, entretanto, foram orientadas não apenas pelas metodologias de mapeamento e o interesse dos pesquisadores, mas pelos moradores, na grande maioria das vezes, indicando a necessidade de regate de urnas, com a negociação de locais para a abertura de unidades de escavação.

4) Ações para preservação pública e gestão do patrimônio, que no caso, englobaram atividades de educação patrimonial (Parente, 2012; Parente e Gomes, 2011), diagnósticos para musealização com objetivo de promover a extroversão do conhecimento produzido para as comunidades locais (Barreto, 2012) bem como de ações para a conservação e preservação do patrimônio arqueológico in situ (Lima, 2014b). Essas ações foram realizadas como projetos específicos, mas relacionados essa pesquisa.

Por fim, algum esforço foi demandado para realização um diagnóstico para elaboração de um programa de educação patrimonial (Gomes 2011a, Gomes, 2012; Parente \& Gomes 2011, Parente 2012)․ Diversas estratégias foram usadas em períodos

\footnotetext{
${ }^{6}$ Essa participação comunitária no trabalho de campo especificamente ocorre através do vínculo financeiro, incluindo o maior número de pessoas possível. A escolha desses assistentes, contudo, foi feita pela própria comunidade, que o faz conforme as necessidades de cada domicílio e relações políticas internas. Houve também o vínculo voluntário, quando moradores se interessam pelo trabalho em si, visto que é atípico o desenvolvimento de pesquisas na própria comunidade, quase sempre realizadas nas áreas adjacentes de floresta. A presença de um grupo de pesquisadores motiva o acompanhamento mais intenso dos trabalhos, e as escavações são momentos privilegiados para a reflexão sobre o passado. Moradores se oferecem para escavar, observam e pedem explicações sobre anotações, etc. Na escavação do sítio São Miguel do Cacau, foram propostas atividades efetivas de cunho colaborativo, nessa ocasião a presença de uma educadora entre os arqueólogos foi fundamental e experimentamos o compartilhamento de informações e registros, quando os critérios levados em consideração para o registro que os moradores fizeram foram quase sempre uma descrição minuciosa da paisagem.

7 As atividades ocorreram entre 2010 e 2012, período que morei na cidade de Tefé, com fácil acesso e logística para visitas às comunidades. Foram ao todo nove viagens de campo, em três delas estive
} 
concomitantes às escavações e em etapas específicas de campo, desenvolvido entre seis comunidades do Lago Amanã: Boa Esperança, Bom Jesus do Baré, Ubim, Kalafate, Monte Sinai e São Miguel do Cacau.

A principal questão era compreender as relações que os moradores mantêm com o patrimônio arqueológico diariamente, e como essas relações influenciam no registro, através do uso e formação contínua das paisagens locais. Buscou-se obter informações que subsidiem a elaboração de recursos e atividades educacionais, considerando a diversidade de significação do patrimônio arqueológico. No primeiro momento, os esforços se concentraram em estabelecer um diálogo com líderes, antigos moradores, professores e artesãos de cada comunidade, identificando significações atribuídas aos sítios, empreendendo uma observação preliminar do uso atual do espaço, conhecimentos sobre o ambiente e o entendimento sobre sua própria história.

A reflexão que será apresentada na próxima sessão resulta de informações obtidas através de visitas às casas, do acompanhamento de atividades cotidianas (no roçado, casa de farinha, tratamento de peixe, tarefas de limpeza, almoço) e de conversas informais. Espontaneamente, realizaram-se pequenas reuniões com núcleos familiares que, quando possível, foram gravadas em vídeo ou voz. Não havia roteiro de entrevistas, mas procurouse trazer à tona discussões sobre memória, transmissão de conhecimentos, diversidade cultural, valorização da história local e pesquisa arqueológica (o que é, métodos, resultados de pesquisas, comparação com outras áreas). Em um segundo momento, o acesso à ampla produção científica desenvolvida nos últimos anos pelo IDSM permitiu incorporar informações cedidas pelos moradores a diversos pesquisadores (Pereira et al. 2006, Pereira 2008, Soares 2006, Sousa 2008). A escolha por uma etnografia, com a observação e participação da rotina diária das comunidades, permitiu-nos acessar discursos locais sobre o passado, onde a paisagem seria o maior índice de continuidade entre as ocupações de diferentes escalas temporais.

As percepções dos moradores sobre a arqueologia, de início estava exclusivamente associada à "história dos índios", procuramos refinar a questão de modo a estabelecer vínculos entre os moradores e a pesquisa. Foi sob uma perspectiva da disciplina como um modo de produzir conhecimento sobre a "história do lugar" que se estabeleceu um diálogo

acompanhada da educadora Tereza Parente, naquele período vinculada ao Museu de Arqueologia e Etnologia da Universidade de São Paulo. Os campos variaram de 7 a 24 dias de duração cada, que somaram ao fim 102 dias. Esta reflexão resulta do envolvimento que construí com cinco famílias na comunidade Boa Esperança, quatro famílias na comunidade Bom Jesus do Baré, duas famílias na comunidade Kalafate e a família Silva Araújo, formada pelo casal Raimunda da Silva e Otílio Feitosa (Seu Mimi), cuja família extensa ocupa as comunidades Ubim e São Miguel do Cacau. 
entre as pesquisas em arqueologia e o conhecimento dos moradores (Gomes 2011a, Parente \& Gomes 2011). Esse aspecto é fundamental, pois para os moradores de Amanã, a construção da narrativa histórica é feita a partir das relações de parentesco, uma característica que em uma escala local se relaciona com um fenômeno já verificado por outros pesquisadores (Lima, 1994; Alencar, 2006), bem como em uma escala mais ampla com a literatura antropológica sobre a construção de narrativas históricas em sociedades tradicionais na Amazônia (Gow, 2006).

De algum modo, buscou-se abarcar o estudo das antigas ocupações analisadas através do registro arqueológico considerado em seu contexto, cultura material, manejo de recursos naturais, sem perder de vista as ocupações atuais, que podem ser compreendidas através de um trabalho sistemático de documentação e registro de aspectos do mundo vivido dessas comunidades, através de memórias de antigos moradores, formas de organização do espaço, construção de paisagens, sentidos e significados dos lugares.

3. Comunidades e patrimônio arqueológico ${ }^{8}$

A comunidade Boa Esperança se encontra assentada sobre um sítio arqueológico de quinze hectares, formado por quatro componentes culturais com uma longa cronologia de ocupações, iniciadas há aproximadamente 3.200 anos. Na área de maior circulação da comunidade, são encontrados grandes recipientes cerâmicos (urnas) aflorando à superfície, o que parece ter sido no passado uma área específica de deposição de estruturas funerárias (Figura 3).A formação da comunidade está relacionada à chegada de famílias cujos membros vieram de outras regiões e, dessa forma, não estavam relacionadas, anteriormente, por parentesco, com moradores mais antigos ou com as famílias que iniciaram a exploração de recursos de Amanã.

Na década de 1970, famílias do rio Juruá foram trazidas por um parente que havia se tornado patrão no município de Coari (AM). Primeiramente estabelecidas no Igarapé Juá Grande, deslocaram-se para o lugar atual por fatores sociais e ambientais, como a queda na produção da castanha e da sorva, o falecimento do patrão e o isolamento geográfico durante a seca. No final da década de 1980, foram feitas as primeiras roças e, após um ano, quando já estavam maduras, mudaram as casas de lugar (Soares 2006). Grande parte dos

\footnotetext{
${ }^{8}$ Nesta seção as frases e palavras em itálico se referem às falas dos moradores e termos locais. Grande parte dessas informações já foi publicada no artigo "Arqueologia comunitária na RDS Amanã: história, alteridade e patrimônio arqueológico” em parceria com Rafael Santos e Bernardo Costa, Amazônica: Revista de Antropologia, n.
} 
moradores da Boa Esperança reconhece e enfatiza a descendência dos nordestinos ou cearenses, autodenominam-se arigós e são assim classificados por moradores de outras comunidades. Boa Esperança também é reconhecida como a maior e mais organizada comunidade da RDS Amanã, possuindo 52 domicílios e 250 moradores (IDSM 2010). Atuante na organização comunitária, possui relações políticas com os municípios de Tefé e Maraã, com representação política através de um vereador morador da comunidade.

A transformação nos sistemas de produção, mudando a ênfase no extrativismo para a agricultura, tornou a farinha de mandioca a principal fonte de produção e comercialização dos moradores de Boa Esperança (Pereira 2008). Esses aspectos políticos da comunidade a destacam como um local que agrega pessoas da região, especialmente por estar ali a maior escola entre as comunidades do lago Amanã, o que faz da Boa Esperança um polo de educação para crianças e adultos.

Bom Jesus do Baré e Kalafate são comunidades de maior antiguidade de ocupação, assentadas sobre sítios arqueológicos de pequenas proporções, com 0,5 ha e 1,4 ha, respectivamente, destinados exclusivamente para a deposição de urnas funerárias. Ambas as comunidades possuem laços de parentesco mais antigos na região e um padrão de ocupação historicamente consolidado através do uso de áreas para atividades extrativistas. É este também o caso da família Silva Araújo ${ }^{9}$, que forma as comunidades Ubim, Bom Socorro e São Miguel do Cacau.

O grupo extenso de parentes do Bom Jesus do Baré, que descende de uma família estabelecida na área do lago Amanã na década de 1930, ocupa uma posição privilegiada nas redes que regulam o direito de acesso e usufruto de recursos naturais. Disputas sobre o uso de áreas e exploração de recursos rodeiam a comunidade e a família Silva Araújo, por isso, são mediadas seguindo a lógica do pertencimento a grupos de parentes, por relações de descendência, casamento e corresidência (Lima et al. 2006). Essa comunidade concentra poucos moradores e possui uma escola que oferece educação infantil, com um quadro pequeno de professores.

No que tange aos vestígios arqueológicos, alguns significados são compartilhados em todas as comunidades trabalhadas, embora sejam aparentes diferentes interações dos moradores. Os grafismos das cerâmicas arqueológicas são entendidos como uma linguagem

\footnotetext{
${ }^{9}$ A estratégia de ocupação do espaço da família Silva Araújo (D. Dica e Seu Mimim) é a utilização de Bom Socorro (uma comunidade familiar localizada mais próxima à várzea) e do Ubim e São Miguel do Cacau (terra firme). Mensalmente, eles ocupam as duas áreas, fazendo grande esforço para manter os dois lugares, buscando se beneficiar disso. Enquanto criam gado no Bom Socorro, que também tem um lago e é mais farto de peixe, os outros dois lugares tem grandes áreas de terra firme para cultivos, caça e extração de castanha (Coelho 2012).
} 
"que só os indios deveriam entender". Esta é uma interpretação recorrente de diversos moradores em diferente comunidades, que comparam as línguas indígenas com outras como o alemão ou chinês, às quais afirmam ser impossíveis de compreender

As urnas são os vestígios mais abundantes na RDS Amanã, em 13 sítios já foram contabilizados 390 vasos aflorando em superfície (Furquim, 2014). Apesar disso há entre os moradores um temor das urnas cerâmicas que podem conter ossos, isto foi observado quando por várias vezes uma estória sobre escavação de uma urna com existência de ossos teria causado um inchaço ou alergia a um morador que enterrou a urna novamente e parece não ter escavado outra. O receio de alguns moradores em intervir nos vestígios é também causado pelas visagens (Galvão, 1954) que dizem terem sido frequentes no inicio da ocupação de Boa Esperança.

Estes objetos já foram alvo de escavações estimuladas pela comum noção que guardam tesouros e objetos valiosos. A estória muito comum no Brasil inteiro de uma pessoa sonhar com o local de um pote e apenas essa pessoa encontra-lo, em Amanã, as personagens ganham características valorativas e éticas, como o "amigo preguiçoso" e o "amigo trabalhador", mas "ganancioso".

Havia dois amigos, o primeiro um pouco preguiçoso que gostava de passar horas na sua rede e não tinha muito afago ao trabalho, o segundo, era bastante trabalhador, contudo ambicioso. O amigo preguiçoso certa noite sonhou com um pote cheio de ouro, no sonho the era mostrado o local exato onde o pote estava enterrado e como faria para chegar ao local. Inquieto com o sonho contou ao amigo trabalhador e ambicioso que escutando a história ficou impressionado e com muita vontade de encontrar o pote. O amigo preguiçoso não tão animado com o trabalho que teria para encontrar o pote deixou de lado o sonho ficando em sua rede, enquanto o amigo ambicioso com certa avareza decidiu ir sozinho e escondido até o local e ficar com o ouro para ele. Assim, como havia sido mostrado no sonho do amigo, encontrou o local e lá havia de fato um pote enterrado. Ao abrir o pote, no entanto, o amigo ambicioso se deparou com muitas cabas pretas que voaram em sua direção. Aborrecido, achando que a história era uma peça pregada por seu amigo preguiçoso, resolveu dar o "troco". Fechou o pote, que ainda continha muitas cabas e com muito esforço levou o pote até a casa do amigo. Chegando lá, o amigo estava deitado em sua rede e pela janela o homem jogou o pote pesado dentro da casa, foi quando o pote se quebrou cheio de ouro.

Ao final da história, o interlocutor chama minha atenção para o fato que ela é uma ilustração sobre a ganância e o cuidado que se deve ter ao contar os sonhos e planos futuros às pessoas. Portanto, a mim parece interessante, o objeto arqueológico ser parte de uma narrativa local onde estão embutidos certos valores éticos e morais.

$\mathrm{Na}$ comunidade Boa Esperança, é cultivada uma curiosidade bastante frequente sobre as pesquias e os obetos que encontram no terreno: são comuns relatos de coleta de 
peças de cerâmicas e escavações de urnas que ocorriam antes do início das pesquisas arqueológicas. Após anos de contínuas atividades de pesquisa, os moradores mantêm peças arqueológicas em suas casas, apesar de haver cessado o empreendimento de escavações amadoras.

A percepção dos moradores em relação aos vestígios arqueológicos é construída de maneira reflexiva, em que se misturam elaborações próprias e as informações dos pesquisadores com os quais convivem. Esse conhecimento elaborado em torno dos vestígios aponta para uma série de teorias locais, sobretudo a relação entre os antigos habitantes do Amanã e a categoria de "índio" e suas contrapartes, como "civilizado" ou "arigó".

Os moradores associam as concreções de ferro no solo às pinturas que observam nos fragmentos cerâmicos, nomeando as concreções como "pincel de índio". Perguntas como “é verdade que Boa Esperança já foi uma grande aldeia de índio?”, permitiram perceber o interesse que os moradores têm em entender as pesquisas arqueológicas e as teorias dos pesquisadores acerca dos vestígios.

As mulheres interpretam a existência da grande quantidade de vestígios cerâmicos ao fato de que ali no passado pode ter sido um local especializado de produção cerâmica. Dona Valdízia refere-se à Boa Esperança como uma antiga olaria de indio (Gomes 2010), enquanto Dona Conceição, ao ver cacaria por todo lado, explica que isso se deve ao fato da alta qualidade do barro de antigamente. Dona Conceição é uma artesã com experiência em produção cerâmica e afirma que o barro atual não é adequado, devido à grande quantidade de areia misturada. Sua explicação é que os antigos moradores devem ter feito "porcarias" com o barro ou mulheres menstruadas tinham contato com ele (Sousa 2008).

As histórias contadas pelos homens tem relação com as diferentes origens dos moradores, as dificuldades de sobreviver na floresta e os encontros com grupos indígenas. Essas histórias são contadas como eventos acontecidos em lugares diversos e que podem ter sido testemunhados por conhecidos ou não. Uma narrativa coletada por nós sobre como um "índio da cara vermelha brigou com uma onça" demonstra as habilidades indígenas em viver no meio da floresta em contraponto às próprias habilidades dos arigós: “Antes a gente só tirava as coisas da mata, agora a gente é agricultor, a gente caça algumas vezes, mas não somos profissionais, já os índios são caçadores por profissão, são conhecedores da mata." (Antônio, agricultor, Comunidade Boa Esperança, outubro de 2010). 
Na descrição dessas categorias sociais, prevalece uma percepção na qual os índios seriam "caçadores" e os moradores de Boa Esperança, "agricultores". Prevalece ainda outra oposição comum no contexto do médio Solimões e afluentes, entre indio e civilizado: "a gente é civilizado, e tem índio que é. No Rio Negro, tem São Gabriel onde até o prefeito é índio, só tem índio!" A categoria de civilizado é profundamente marcada pela história da colonização na região, sendo caracterizada pela adesão às religiões cristãs, a capacidade de expressar-se através da língua portuguesa, o consumo de mercadorias obtidas no comércio e também através do engajamento no trabalho a um patrão (Santos 2012, Deturche 2009).

A adesão às formas regionais de organização política, sobretudo a organização comunitária promovida pelo Movimento de Educação de Base (MEB) nas décadas de 1970 e 1980, também contribui para a descrição de pessoas como civilizadas. A fala desse interlocutor expressa, com alguma ênfase, o fato de que haveria indios civilizados.

$\mathrm{Na}$ comunidade Bom Jesus do Baré, as percepções sobre os vestígios arqueológicos são mais tênues. É evidente a dificuldade em manter uma conversa longa com os moradores, quando os cacos de indio são o tema central do diálogo. O mesmo ocorre na comunidade Kalafate, ainda que os moradores estejam familiarizados com o tema, associando aos "cacos de índio" muitas histórias sobre povos indígenas - nomeando os locais onde mais aparecem vestígios e descrevendo suas características estilísticas. Ao contrário de Boa Esperança, nessas duas comunidades, os moradores demonstram maior distanciamento com os vasos que encontram próximos às casas. Relatam que grande parte do material que havia na superfície desapareceu e que, ao encontrarem um vaso durante a capina do terreiro, jogavam-no para o lado.

Nessas comunidades, enquanto realizei os campos, não foram identificadas coleções de material arqueológico ou, ao menos, qualquer objeto arqueológico guardado nas casas visitadas. Isso é justificado pela antiguidade de ocupação do lugar, pois seus moradores afirmam que já se acostumaram com os cacos. Contudo, na comunidade Kalafate, onde as conversas foram mais constantes com as famílias de Dona Bebé e Seu Jota, antigos moradores e interlocutores-chave, chamam atenção para a "coleção" que esses dois moradores mantêm em seus domicílios. No caso de Dona Bebé, são guardadas diversas coisas da floresta (cascas de árvores, folhas, sementes) que servem para manufatura de remédios. Na casa de Seu Jota, há diversos objetos que perpassam as esferas do curioso e do sobrenatural, um dos objetos é a "maçã-de-boi" levada sempre nas caças que fazia. Isto é, os moradores elegem-se outros objetos para falarem de si, enquanto Boa Esperança abriga uma coleção cerâmica na rádio comunitária e após anos de contínuas atividades de 
pesquisa, ainda mantêm peças arqueológicas em suas casas - apesar de haver cessado o empreendimento de escavações amadoras.
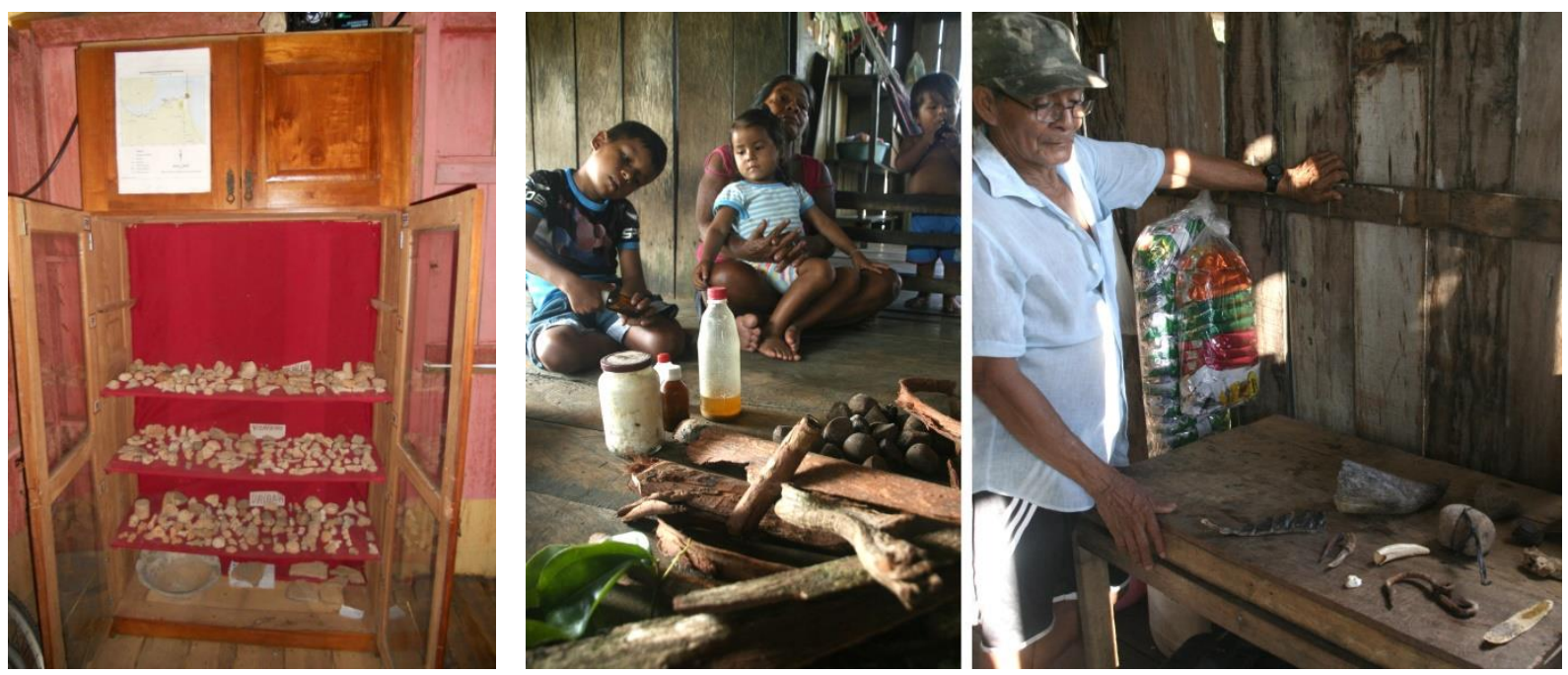

Figura 2: Coleção de peças arqueológicas da comunidade Boa Esperança (Foto: Cristiana Barreto). A direita: Comunidade Kalafate e as coleções de Dona Bebé e Seu Jota (Fotos: Jaqueline Gomes).

De modo geral, os moradores dessas comunidades mostram-se reservados em demonstrar curiosidade pelas pesquisas arqueológicas, mas sempre são solícitos ao falar sobre a própria comunidade, sobre como a vida mudou desde o tempo dos patrões até a criação da reserva. Em Bom Jesus do Baré, uma personagem importante no imaginário dos moradores é a avó Rosa Tavares. Segundo a família, ela era uma india peruana que foi levada para o Juruá por um "homem muito traiçoeiro e vingativo", conseguindo fugir com a ajuda de Henrique Tavares, nordestino e trabalhador dos seringais com quem se casou, e juntos chegaram ao Amanã.

Essa perspectiva de valorizar o elemento indígena da família tem ainda mais força nas falas de Dona Deusa, que descreveu a utilidade das vasilhas de barro, tanto para sepultamentos como para fazer o caissuma, bebida fermentada que aprendeu a fazer com a avó a partir da macaxeira (Manihot esculenta) e do abacaxi (Ananas comosus). Modos de fazer cerâmica, locais de coleta de barro em área do lago, bem como materiais utilizados para pintura e acabamento dos vasos são detalhados por ela.

A comunidade Kalafate também lança mão das relações de parentesco com indígenas, de modo a demonstrar um conhecimento próximo sobre o "tipo" de gente produtora dos vestígios arqueológicos. Em uma de nossas reuniões, em outubro de 2011, um dos assuntos levantados por eles foi a concepção de que o trabalho tenta escrever a história dos índios que habitaram a região, ilustrada pela fala de um dos moradores sobre o fato de eles serem indios mansos (Gomes 2012). 
Em ambas as comunidades, seus moradores se definem como amazonenses, muito claros, contudo, de uma origem múltipla. Os vestígios arqueológicos engendram falas sobre o elemento indígena na constituição dessas comunidades e acionam um conhecimento sobre o modo de fazer, um domínio das técnicas de produção cerâmica, com indicação de locais para coleta de matéria prima, a cadeia operatória na manufatura, modos de uso e funções dos objetos. O que é o oposto de Boa Esperança, comunidade que protagonizou o surgimento do projeto de arqueologia, cuja curiosidade em relação aos vestígios arqueológicos é da parte que claramente se reconhece e é reconhecida por outras comunidades como Arigó.

Os critérios de identidade e categorias sociais construídos localmente não estão implicados apenas na ascendência de pessoas e grupos, sendo profundamente influenciados pelas relações atualizadas no presente - especialmente de casamento e compadrio. Os interlocutores podem enfatizar a origem indígena ou nordestina de seus ancestrais, mas as descrições que fazem de si mesmos e de outros não estarão circunscritas a apenas um "tipo de gente", seja ele caboclo, arigó ou indio (Gow 1991, Souza 2011, Santos 2012). No lago Amanã e em outros lugares da região do médio Solimões, a diversidade de origem das populações locais geralmente é resumida pelas populações locais no ser amažnense.

Em suma, os vestígios arqueológicos no caso de Boa Esperança ou nas outras comunidades, apontam para formas de ocupação prévias, por grupos humanos distintos dos atuais moradores: são pensados como "índios", que viveram num passado que não é recontado na memória. Mas na primeira percebe-se o cultivo de uma intensa curiosidade sobre o passado do lugar e, no entanto, os moradores se apropriam dos vestígios arqueológicos de modo que demarcam uma diferença radical entre eles mesmos e aqueles que ocuparam o lugar no passado. Pode-se considerar que que uma forte alteridade é engendrada através dos fragmentos, e isto é observado nas falas e narrativas sobre índios revelando uma concepção do indígena como o grande conhecedor da floresta em contraponto ao arigó. Nas comunidades Bom Jesus do Baré e Kalafate, os moradores não possuem discursos mais elaborados sobre os lugares dos vestígios arqueológicos, mas por outro lado falam de conhecimentos específicos sobre produção e função das cerâmicas, nos remetem a origem indígena-peruana da avó, as relações de casamento e compadrio atuais com indigenas. Os moradores, embora reconheçam uma origem múltipla, referem a si mesmos como amaz̧onenses e não se apropriam dos vestígios para demarcar semelhanças ou diferenças. De outra forma, os vestígios arqueológicos desencadeiam falas sobre o elemento indígena na constituição dessas comunidades e acionam um conhecimento sobre 
o modo de fazer, um domínio das técnicas de produção cerâmica, com indicação de locais para coleta de matéria prima, a cadeia operatória na manufatura, modos de uso e funções dos objetos.

Essa breve exposição vai de encontro a uma preocupação latente na reflexão arqueológica contemporânea, na qual tem se discutido o papel do arqueólogo enquanto quem decide que sítio estudar, destruir, preservar. Como já demonstrou Silva (2009), não é apenas o arqueólogo que valoriza o conhecimento sobre o passado e as razões para a preservação do patrimônio arqueológico são múltiplas, contextuais e situacionais. No caso de Amanã as dinâmicas sociais permeadas por encontros entre o passado e o presente, são intermediadas por relações de identidade e alteridade dos grupos locais. Embora a tônica sobre o passado seja semelhante na forma de contrução das narrativas históricas, associadas sempre ao parentesco, na Boa Esperança há um interesse sobre o passado de modo a destacar a diferença e alteridade, sendo seus moradores aqueles mais interessados na pesquisa arqueológica e gestão do patrimônio. Enquanto nas outras comunidades, este interesse é mais difuso, relacionado à possibilidade de um atrativo turístico, mais interessante aos que são de fora.

Há de se ponderar que a continuidade das pesquisas na área, com o efetivo envolvimento local para gestão comunitária do patrimônio arqueológico, deverá levar em consideração alguns desses pontos sensíveis da trajetória histórica e processos de subjetivação dessas comunidades.

4. Paisagens de Amanã: continuidades e transformações na longa duração

Os moradores não traçam uma relação entre seu mundo vivido e uma continuidade histórica de suas habilidades de engajamento com ambiente a um passado índigena. Mas ao passso que esta continuidade não se expressa no discurso e narrativas, ela compõe a prática diária. Parto do pressuposto que o conhecimento local sobre o ambiente é contruido através da improvisação de diversas capacidades e recursos, da imitação e recomposição de habilidades (Harris, 2005; Ingold), mas há uma profundidade histórica inerente nessas relações (Belée, 2006:45).

O refinado conhecimento paisagístico local é facilmente percebido e extrovertido nas falas dos moradores, que nomeiam as plantas (nome dado às espécies perenes cultivadas) de seu terreiro, dos caminhos utilizados até a roça, castanhais e sítios, atribuindo a estas uma série de saberes e eventos. Quatro casos de Boa Esperança podem ilustrar essa habilidade e 
ainda nos oferecem elementos para pensar em como essa paisagem se relaciona às memórias do grupo familiar e uma ativa "construção":

i) o buritizal sem espinho (Mauritia flexuosa) plantado há quinze anos, por ocasião da doação de mudas pelo então prefeito de Alvarães;

ii) a pupunha marajá (Bactris gasipaes) associada com a história de um homem que, segundo se dizia, andava com índios e quando visitou a comunidade não levava isqueiro pela mata, pois dominava a técnica de acender cigarros fazendo fogo com a raiz da planta;

iii) uma única soveira (Sorbus domestica L.) no caminho da comunidade à roça tem diversos cortes de sangria em seu tronco, testemunho da prática de retirada do látex ;

iv) em meio a um açaizal, uma única seringueira (Hevea brasiliensis)

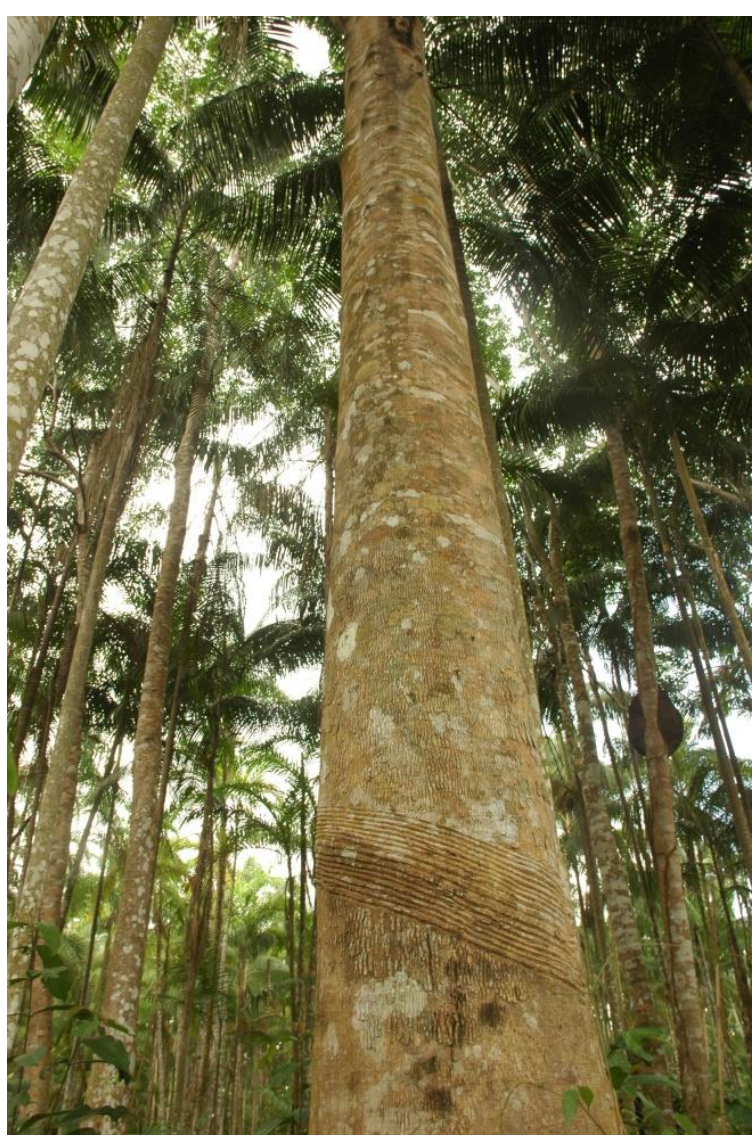

Figura 3: Seringueira do açaizal. Comunidade Boa Esperança, 2010. também apresenta cortes de sangria em seu tronco (Figura 3).

Esses dois últimos exemplos podem ser entendidos como marcos de uma paisagem de memória, remetendo ao tempo da exploração gomífera. A referência ao trabalho nos seringais feito no passado vem acompanhada da ideia de uma origem arigó, remetida muitas vezes como um contraponto à categoria de indio. O mais interessante neste caso é que um passeio pela comunidade com um jovem já nascido neste lugar pode ter uma pausa nesta seringueira para uma demonstração de como fazer a sangria e retirada do látex, mesmo sem ele próprio ter vivenciado a rotina e trabalho de seus pais e avós.

Em todas as comunidades a agricultura é a principal atividade econômica, com o cultivo da mandioca voltado para o consumo e o mercado. Na terra firme, onde os solos possuem menores estoques de nutrientes, restringindo o período de cultivo da mandioca 
para no máximo dois anos, o manejo baseado no sistema "derruba e queima" seguido de pousio é a principal característica desse sistema de produção (Balée, 1987).

Pereira (2008) define uma tipologia local de áreas utilizadas para a agricultura com base nas distinções e uso de diferentes ambientes: restinga, baixo, praias, barranco, terra firme e terra preta. Para essa reflexão nos interessa os dois últimos. Os moradores também distinguem os sistemas de cultivo em roçado (roça), sítio (pomar), quintais/terreiros e caminhos.

As terras firmes são terrenos que não sofrem alagação e possuem solos com menor estoque de nutrientes, o que torna a queima e a coivara importantes técnicas que garantem, em curto prazo, respostas satisfatórias ao uso do terreno para o cultivo de espécies anuais como a mandioca. As terras pretas são as áreas de terra preta arqueológica, reconhecidas pela constituição do solo, profundidade da camada orgânica e presença de vestígios cerâmicos. São consideradas ideais para o cultivo de diversas espécies, já que possuem solo com teores de nutrientes muito maiores que nas áreas de terra firme. Estão sempre próximas ou no interior das comunidades e são utilizadas para o estabelecimento de sitios (quintais).

O roçado é exclusivamente usado para identificar o cultivo da mandioca e variedades, além de outras espécies como o milho, cará, pupunha, açaí e abacate. Entretanto, a mandioca é sempre a espécie predominante. Um roçado geralmente possui um hectare e é definido em função do tamanho da família e/ou planejamento de produção de excedente para a venda ${ }^{10}$.

Os sítios são áreas com plantas frutíferas e variam muito quanto à composição e ao manejo, de acordo com o propósito e sua localização com relação à sede da comunidade, é sem dúvida, aquele termo cuja variação de significados é grande e se relaciona não só complexa rede de cultivos, mas, a meu ver, são os elos mais imporantes na história de longa duração na RDS Amanã. Os sitios (pomares) destacam-se como áreas manejadas com o objetivo de produção para o mercado e possuem menor variedade de espécies, com predominância daquelas com valor econômico (açaí, pupunha, abacate, cupuaçu, cacau). Os quintais e terreiros estão localizados próximos às casas e apresentam maior diversidade de espécies com manejo mais intenso, sendo importantes para a produção de alimentos e remédios e para a aclimatação de novas espécies. O terreiro é a área mais próxima às casas com capinação frequente e limpeza quase diária, e o quintal propriamente dito é a parte

\footnotetext{
${ }^{10}$ Apesar de as mulheres participarem ativamente do roçado, a interação feminina com o ambiente está mais associada ao espaço doméstico. São elas que cuidam das pequenas hortas que são cultivadas em jardins suspensos próximos às casas, fazendo uso de plantas para o tempero, tratamento de doenças e cuidados relacionados ao parto e ao recém-nascido. Esses conhecimentos e usos de espécies vegetais indicam as diferenças de gênero no cotidiano ribeirinho, já observado em trabalhos etno-arqueológicos (Machado, 2010: 356).
} 
restante que ocupa a maior porção do espaço ${ }^{11}$. Os caminhos são trilhas usadas entre a comunidade e as áreas de cultivo, nesses espaços são plantadas diversas espécies, como a macaxeira e frutíferas. Pode ser considerada uma estratégia elaborada para o fornecimento de sombra e fácil coleta de alimentos.

Pereira e colaboradores (2006) chamam atenção para o fato de que os sistemas de produção em Amanã são dispostos geograficamente de forma difusa ao longo do terreno, caracterizando uma dinâmica que forma, na área de uso das comunidades, mosaicos de paisagens constituídas por sítios, capoeiras, roçados e mata.

No padrão local de agricultura migratória, cada família mantém geralmente de um a dois roçados por ano para a produção de farinha de mandioca, e em paralelo, sítios e capoeiras - que são diferenciados através do estágio de sucessão vegetal e do investimento de trabalho na área. Considerada como uma prática "tradicional”, a associação roça e sítio como principal estratégia de produção é recente. Como já vimos, até a segunda metade do século XX, o sistema de produção dominante era o extrativismo (coleta do leite da seringa, da sorva e da quebra da castanha nas matas de terra firme), o cultivo de mandioca limitavase à produção de farinha para consumo, e o plantio de frutíferas concentrado ao redor das casas também para o autoconsumo. Por outro lado, a necessidade de percorrer muitos quilômetros na mata de terra firme, permitia o consumo e manejo de uma forma bastante difusa e espaçada. Essa dinâmica se modificou gradativamente com o declínio da economia extrativista, a partir da década de 1970, através de fluxos de povoamento que aumentaram a população residente, as estratégias de produção locais se modificaram totalmente e, com elas, a paisagem. As picadas na terra frime se "fecharam" e junto a elas as porções de "mata manejada", em 40 anos, as formas de manejo da vegetação passaram de um modelo espacialmente espalhado para um modelo mais localizado e com um nível de manejo mais intenso, do qual os sítios são emblemáticos (Rognant, 2014).

Em um primeiro momento a hipótese de que os moradores teriam considerado a presença dos vestígios arqueológicos para a escolha dos assentamentos foi testada. $\mathrm{Na}$ comunidade Bom Jesus do Baré, os descendentes apontaram a existência de castanheiras

\footnotetext{
${ }^{11}$ Em quatro comunidades da RDSA foram identificadas, em quintais, 115 espécies de plantas diferentes, distribuídas em 52 famílias. 37 (32,5\% do total) utilizadas para alimentação, 34 (29, \%), como remédio, oito $(6,9 \%)$, como ornamental e uma (0,9\%), como utensílio doméstico. As outras 35 (30,4\%) são de uso múltiplo. 48 espécies $(41,7 \%)$ possuem porte do tipo arbóreo, dezoito (15,6\%), arbustivo e 49 (42,7\%), herbáceo. As espécies mais comuns nos quintais foram o cupuaçu (Theobroma grandiflorum), o jambo (Eugenia jambo) e a goiaba (Psidium guajava), presentes em quase todas as unidades amostradas ( $92 \%$ do total). Em seguida, a bacaba (Oenocarpus bacaba), com $82 \%$ de frequência, a pupunha, o açaí do mato e a manga (Mangifera indica), verificadas em 75\% das áreas. Quanto ao número de indivíduos por quintal, as espécies mais plantadas foram o açaí do mato (12,2\% do total de indivíduos), o abacate, com 7,8\%, o cupuaçu $(6,8 \%)$, a bacaba $(5,9 \%)$, o limão (Citrus latifolia) $(5,4 \%)$ e a pupunha $(5,3 \%)$ (Pereira et. al, 2006).
} 
no início da ocupação por seus avós (que foram cortadas com o passar dos anos devido aos acidentes com quedas de ouriços), mas atribuíram a escolha do lugar à percepção de que $a$ terra é boa. Já na Boa Esperança, segundo informações coletadas por Soares (2006), os moradores migraram do Juá Grande para a área conhecida como Ponta da Samaúma, motivados pelo menor distanciamento dos roçados em relação às casas, o que reduz consideravelmente a penosidade do trabalho agrícola:

"Veio bem uns seis moradores ver. Aí disseram - Lá é um pouco sacrificoso, porque tem muito, muito mato pra desmatar, tá um bocado feio. Cobra tinha bastante, não podia nem botar o pé. Aqui na frente, era capoeira aqui, acho que era do tempo dessas urnas, sei lá o quê que é isso! Aí vieram e começaram a trabalhar. Fizeram primeiro os roçados aqui, aí nós plantamos, aí, a gente vinha de lá, limpar aqui, zelar. Dava uma hora de rabeta. Nós trouxemos pra plantar abacate, limão, laranja... vários tipos de planta" (Moradora de Boa Esperança entrevistada em Maio de 2005 citado por Soares 2006 grifos nossos).

Apenas com o tempo, com a abertura de caminhos e as limpezas de terreiros próximos às casas, o avistamento dos vestígios tornou-se frequente. Aqui, a preferência por espaços antropizados parece ter sido regida pelas observações de espécies vegetais - uma capoeira que seria mais facilmente retirada - e do regime de águas no período da cheia.

Em discussão das formas de posse (ownership) e propriedade (property) na Amazônia indígena, Brightman (2010) propõe uma conexão entre a dimensão antropogênica do ambiente amazônico e os regimes de apropriação nativos (idem: 157). De fato, a ênfase na dimensão criativa e transformativa nos regimes de propriedade e posse indígenas nos parece uma chave analítica possível para pensar as maneiras de legitimação da posse da terra na região de Amanã, especialmente devido à intensa prática da agricultura itinerante naquela área. A pesquisa de Alencar (2007) enumera que as "capoeiras e plantas cultivadas" seriam elementos-chave para se "reivindicar o uso" de um território (idem: 133), sobretudo quando se tratam de locais cultivados no passado e reivindicados no presente. Uma vez que o trabalho na agricultura está profundamente implicado nas dinâmicas do parentesco regional (e vice-versa) (Lima, 2005), os regimes de posse no Amanã integram as dinâmicas de composição de coletividades e habilidades necessárias para a transformação do ambiente e elaboração de paisagens antrópicas, lugares de domínio e circulação de pessoas humanas. Se observarmos as localizações das maiores comunidades na RDS Amanã, veremos que estão assentadas sobre sítios arqueológicos, em áreas estratégicas de acesso ao lago e igarapés de entrada para ilhas de recursos, seja para caça ou extração. À excessão de Boa 
Esperança, os moradores se referem aos castanhais como um elemento que motivou o estabelecimento das famílias.

A associação entre castanhais e a ocupação humana pré-colonial é recorrente na literatura (Balée 1989; Conklin 2001; Guix, 2005; Pärssinen et al. 2009; Ranzi et al. 2007). A intervenção humana é crucial para o estabelecimento dessas floretas e uma revisão de casos etnográficos sugere como práticas culturais específicas podem ter facilitado a expansão das antigas populações de castanheiras (Shepard \& Ramirez, 2011).

$\mathrm{Na}$ RDS Amanã, o uso atual do espaço é realizado com o intenso manejo das espécies vegetais. Localmente as manchas de terra preta são classificadas como quintais e parece haver uma intencionalidade em conservá-las. A título de exemplo, Boa Esperança, em termos arqueológicos, pode ser divida em dois setores. O primeiro, composto por dezenas de urnas aflorando na superfície do solo, se configurando como um complexo funerário. Esse setor, que vem sofrendo severos impactos, segue a margem do igarapé Boa Esperança e do lago Amanã e tem formato linear, acompanhando o alinhamento das casas e demais construções. O segundo setor consiste na mancha de terra preta que compreende o fundo das casas. Esta é a maior parte do sítio e se encontra bem conservada, embora venha ocorrendo o crescimento do número de domicílios. Nas áreas de terra preta não são construídos domicílios e outras estruturas, trata-se, ao contrário, de áreas reservadas ao cultivo de frutíferas. Há, portanto, um modo de uso desse recurso que, de certa forma, conserva o patrimônio arqueológico.

A preferência pelo uso e assentamento em espaços previamente antropizados nos permite pensar as atuais ocupações no Lago Amanã como uma sequência que é traçada "como fios de conhecimento que podem ser tecidos de formas diferentes por pessoas diferentes em tempos diferentes" (Machado, 2010:363). Encarar essas escolhas culturais sob uma perspectiva histórica, e de longo prazo, revela questões importantes sobre as relações entre passado e presente.

Furquim e Rognan (2014) em recente análise que reuniu dados etnobotânicos e etnográficos acerca das técnicas agrícolas contemporâneas no Lago Amanã, destacam que as áreas de terras pretas e a proximidade de "pontas" de terra firme com acesso estratégico às vias de circulação e aos recursos foram os principais critérios na escolha da área de moradia ou de uso:

"a paisagem no momento da escolha desses lugares enfatiza a presença de concentrações significativas de plantas úteis (cacoais, açaizais, castanhais, piquiá, paxiubão, mari, andiroba), o que reforça a ideia de uma reincidência entre lugares possivelmente manejados no passado e reutilizados hoje” (Idem, 2014:63) 
Há uma recorrência de espécies encontradas nas áreas de terra preta ou próxima aos sítios arqueológicos, interpretadas localmente como vestígios de cultivo pretérito, com relatos de plantas que nasceram espontaneamente nos primeiros roçados estabelecidos há 20 e 50 anos atrás, com destaque para a variedade de espécies de cacau ${ }^{12}$. Segundo as autoras tais 'plantas' encontradas concentradas em lugares específicos das beiras e "pontas de terra", em áreas consideradas de mata bruta, e aquelas "nascidas" nos roçados, são frequentemente adjetivadas como "dos índios", "dos antigos", "dos outros".

A existência de uma paisagem já antropizada, reconhecida localmente, pode ser explicada também pelo possível processo de quebra de dormência de sementes que podem ter permanecido no solo por um longo período, até que o fogo da agricultura de corte-equeima as reativassem. Dentre essas plantas, algumas compõem parte da biodiversidade utilizada e manejada pelos moradores: os cacaus, abiu-do-índio, goiaba de anta, padu (até a década de 1960) e pimentas foram conservados e integrados nos sítios atuais (para consumo) e manejados de várias formas: poda, limpeza, transplante para outras áreas de plantio (Furquim e Rognant, 2014)

Os sítios são os espaços fundamentais nesse manejo. Partes integrantes do sistema de agricultura corte-equeima, são áreas cuja intenção é de uso mais perene do que a roça, e, sobretudo, uma forma de manejo integrado das terras, da agrobiodiversidade e da vegetação. Neles, estão espécies de uso cotidiano, de finalidade comercial e de valor afetivo, com papel importante nas economias domésticas, parte de uma estratégia de produção flexível e adaptativa, capaz de se transformar conforme as mudanças socioeconômicas locais.

\footnotetext{
${ }^{12}$ Entre as quais, pelo menos duas variedades de pimentas (ova de aruanã, Capsicum chinense; malagetas, Capsicum frutescens; de nhambu, Capsicum spp.); várias de cacau (cacau verdadeiro (Theobroma cacau); cacau jacaré (Theobroma mariae); cupui (Theobroma subincanum); cacau bafute (Theobroma spp.); cabeça de urubu (Theobroma obovatum); cabeça de macaco (Theobroma microcarpum); tucumã (Astrocaryum aculeatum); castanheiras (Bertholletia excelsa); variedade de manivas desconhecidas; goiaba-da-anta (Bellucia dichotoma); padu (Erythroxylum coca var. ipadu); piquiá (Caryocar villosum); ingá (Inga spp.); ingá-açu (Inga cinnamomea).
} 


\section{CAPÍTULO 2}

\section{ARQUEOLOGIA DO MÉdIO SOLIMÕES-JAPURÁ E AS QUESTÕES DA PESQUISA}

1. As primeiras informações arqueológicas e a sequência cultural no médio Solimões e Rio Japurá

Há mais de meio século, quando as pesquisas arqueológicas se intensificaram na Amazônia brasileira, três principais questões orientavam seu desenvolvimento: i) a relação entre os aspectos ambientais e ecológicos e os processos sociais e culturais da ocupação humana; ii) a correlação entre identidade étnica, língua e os vestígios de cultura material; e iii) o impacto da colonização europeia sobre os padrões de organização social e política das populações indígenas (Neves, 1999-2000; 2012; 2014). Apesar de seminais, estas questões que estão profundamente relacionadas entre si, permanecem no centro da agenda de pesquisas contemporâneas, reavivadas não somente pela ampliação dos dados empíricos, mas do refinamento das bases teóricas e analíticas. Os principais modelos de ocupação formulados para explicar a variabilidade da cultura material das antigas populações que habitaram a calha do Amazonas preocuparam-se, em certa medida com estas questões ${ }^{13}$ (Meggers 1987, 1990; Meggers; Evans 1957, 1961, 1983; Lathrap 1970; Brochado, 1989).

Sinteticamente, Meggers e Evans exploraram o conceito de cultura de floreta tropical nas suas hipóteses. Este conceito era parte de uma tipologia que procurou explicar a variabilidade de organização social e política, com forte ênfase da ecologia cultural, determinismo ambiental e neo-evolucionismo, sendo a primeira tentativa de definição de áreas culturais das terras baixas (Steward, 1948). Determinadas basicamente pela ausência de elementos culturais, sociedades do tipo de floresta tropical, seriam compostas por pequenos grupos, com uma organização social igualitária que desenvolveriam a agricultura incipiente ou de coivara, alternando com períodos de nomadismo. $O$ uso de redes, cerâmicas e tecnologias fluviais marcariam essas populações, que englobariam três importantes línguas: Arawak, Caribe e Tui-guarani (Lowie, 1948).

\footnotetext{
${ }^{13}$ Para uma síntese, avaliação e crítica desses modelos conferir Neves, 1999-2000; Lima, 2008; Moraes, 2013; Suzi, 2014. Optou-se nessa revisão tratar especificamente dos modelos de história cultural relacionados à região da Amazônia Central.
} 
A dificuldade de trabalhar com essas tipologias foi explícita nos primeiros trabalhos de campo de Meggers e Evans na Amazônia, diante dos dados empíricos provenientes da foz do Amazonas, na ilha de Marajó, constituído de cerâmicas extremamente elaboradas em áreas que sugeriam a existência de ocupações sedentárias, características típicas de populações mais complexas da região do Caribe e dos Andes (Meggers e Evans, 1957). Esses autores formularam os primeiros modelos de difusão, considerando migrações de populações exógenas para a floresta tropical, e sua degeneração cultural nesse ambiente hostil. Embora, as várzeas apresentassem potencial de subsistência para essas populações, não garantia o desenvolvimento de sociedades densas e sedentárias, mas um padrão de ocupação com grande mobilidade (Meggers, 1987:64).

Lathrap (1970) foi o autor de um modelo bastante abrangente que procurou articular dados arqueológicos, etnológicos e linguísticos disponíveis à época, para propor que os troncos linguísticos Tupi e Arawak, os dois mais difundidos nas terras baixas, tiveram uma origem comum na Amazônia Central por volta de 5.000 BP:

"Esse modelo preconizava que a pressão populacional nas áreas ribeirinhas da Amazônia central, que ele acreditava ter sido o centro mais antigo de desenvolvimento de agricultura e sedentarismo no continente americano, resultaram em um êxodo populacional contínuo centrífugo através da colonização das bacias dos principais afluentes do Amazonas, como o Negro e o Madeira, assim como pela colonização do Solimões e do baixo Amazonas" (Heckenberger et al, 1998:70).

Ambos os modelos atribuem um papel fundamental às várzeas para 0 desenvolvimento, expansão e migrações de diferentes povos (Meggers e Evans, 1968; Lathrap, 1970). Nesse sentido, o rio Solimões possuía grande importância no quadro geral de hipóteses, embora os dados empíricos disponíveis para o seu médio curso sejam ainda hoje pontuais. O rio Japurá, por sua vez, apesar de ser um grande curso hídrico da região, é menos conhecido arqueologicamente.

Esse quadro de razoável desconhecimento arqueológico não significa ausência de informações sobre a diversidade linguística e cultural da região. As referências etnohistóricas, a caracterizam pelo seu intenso movimento comercial, com complexas e extensas redes de trocas de objetos, pessoas e, consequentemente, de aspectos simbólicos. A região é comumente mencionada no circuito de redes existentes no século XVII documentadas por viajantes, e aparenta ser parte de um sistema regular e multidirecional de trocas comerciais entre sociedades ameríndias, estabelecido antes do contato europeu no qual veio se inserir o trânsito de mercadorias ocidentais (Porro, 1995). Especificamente a 
desembocadura do rio Japurá no Solimões, poderia ser entendida de antemão como uma área de grande fluxo cultural, por abarcar diferentes ambientes ecológicos entre as bacias de águas pretas e águas claras da Amazônia.

A diversidade linguística vislumbrada através das fontes etnohistóricas, quando olhadas retrospectivamente, oferecem informações sobre a dinâmica sociopolítica da área do Japurá-Solimões e a paulatina reconfiguração de relações interétnicas, com alianças e conflitos nos primeiros anos de colonização (Carvajal 1542[1942], Acunã, 1641 [1945]; Porro 1995; Ugarte, 2009). É impossível desconsiderar que a presença europeia afetou profundamente um potencial cenário multilinguístico, onde as populações do Solimões foram assoladas por epidemias e por disputas entre portugueses e espanhóis pelo controle do rio e das missões, que garantia o acesso à mão de obra indígena (Lima e Alencar, 2000; Santos, 2012; Souza Junior, 2009).

As primeiras informações arqueológicas sobre o médio Solimões e Japurá ${ }^{14}$ são resultado de observações e coleções formadas por viajantes e missionários, sistematizadas por Herbert (1907), Métraux (1930) e Feriz (1963), que realizaram estudos pioneiros com caracterizações sumárias das cerâmicas da região. Alfred Metraux (1930) realizou uma série de observações sobre cultura material no rio Amazonas, a partir de coleção formada com

contribuições do missionário Constant Tastevin $^{15}$, coletadas na região do lago Tefé e

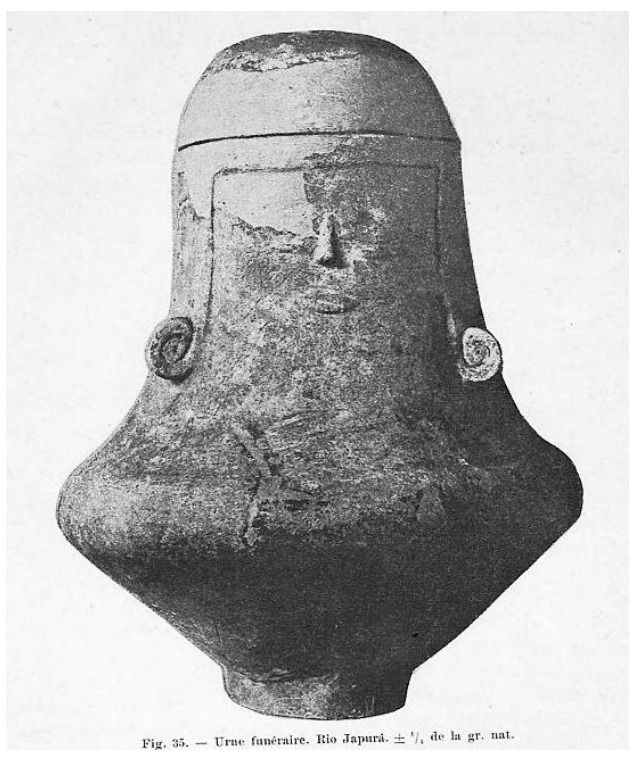

Figura 4: Urna antropomorfa de Mapari, médio Japurá (Metraux, 1930) baixo Japurá e enviadas ao Museu do Homem de Paris (Faulhaber, 2008:5).

A principal informação é sobre uma urna antropomorfa proveniente das proximidades de Mapari, um lago na margem direita do médio curso do Japurá, onde

\footnotetext{
${ }^{14}$ Embora tenha registros sobre os petroglifos do rio Japurá nas publicações iniciais sobre arqueologia brasileira (Netto, 1885:534).

${ }^{15}$ Tastevin no início do século XX morou na cidade de Tefé por 16 anos e registrou de forma detalhada os modos de vida caboclo/ribeirinho dando atenção para produção de cultura material, subsistência, língua, mitos, festas e cantos (Tastevin, [1925] 2008; 137). Nos seus registros que encontramos referências sobre a ausência de moradores permanentes no lago Amanã (Tastevin, [1929] 2008:44), e ainda sobre possíveis reocupações de sítios arqueológicos: "era indispensável ao final dos festejos quebrar todos os vasos que tinham servido à cerimônia; daí o fato de termos perto de casa uma verdadeira mina de cerâmica antiga sobre os mais variados temas" (Tastevin, [1914] 2008:123).
} 
atualmente é uma terra indígena do grupo Kaixana ${ }^{16}$. Especificamente sobre o lago Amanã, temos apontamentos sobre a ocorrência de "campos de urnas" encontrados às margens do lago, registrado por A. Melchior, durante viagem na década 1950, quando coletou fragmentos cerâmicos, que posteriormente foram estudados por Feriz (1963), sendo esta a única referência disponível para lago.

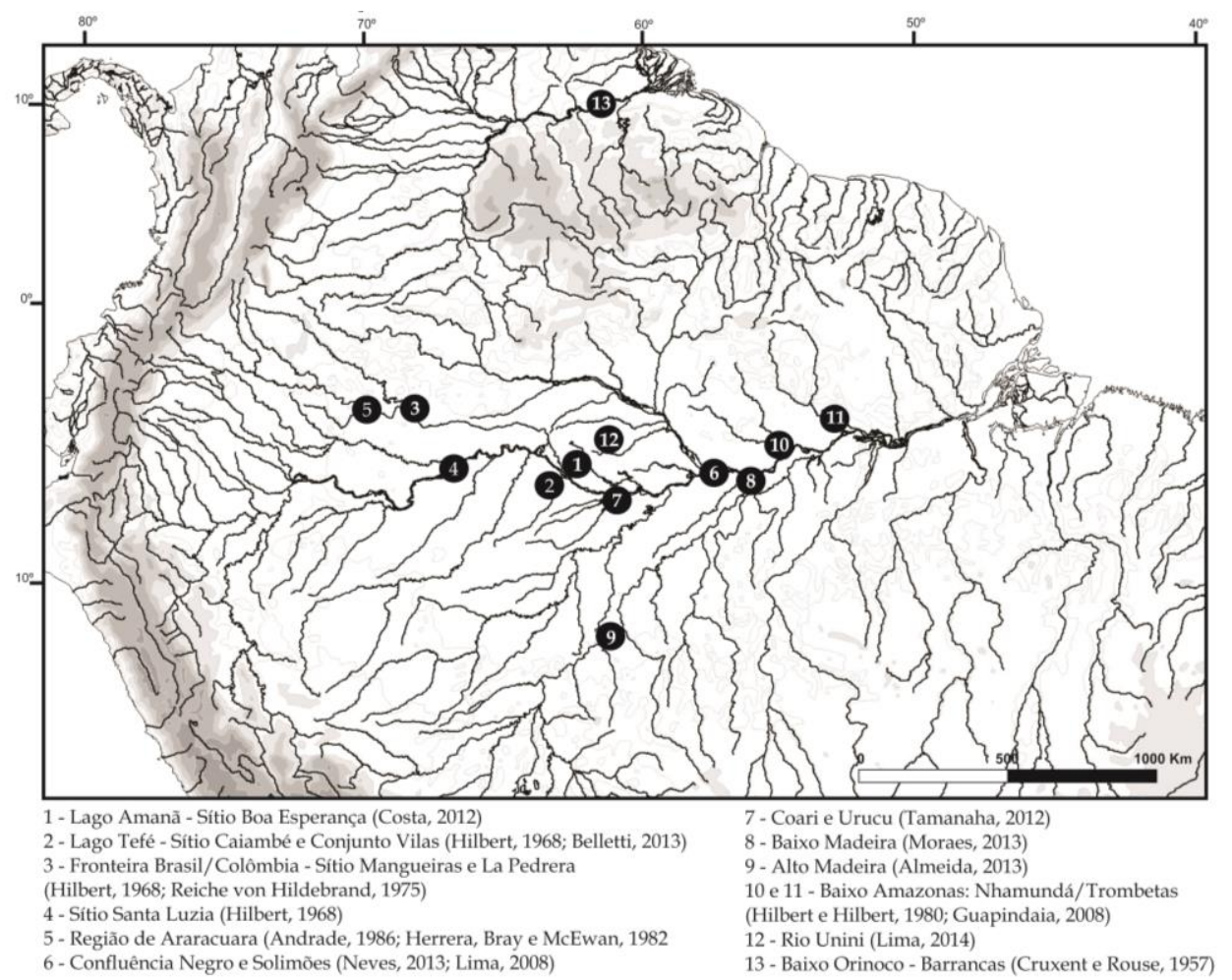

Figura 5: Mapa com a indicação dos sítios e regiões mencionados no capítulo 1. Elaborado por Jaqueline Gomes a partir de base disponível no site:http://silurus.acnastic.org.

O início das pesquisas arqueológicas na região se dá com os trabalhos de campo de Wanda Hanke e Peter Hilbert no final da década 1950, ambas de caráter pontual. Hanke (1959) destaca a presença dos modelados zoomorfos e antropomorfos nas cerâmicas coletadas por ela de forma assistemática em sítios próximos das cidades de Tefé (Tefé e Nogueira), Maraã (Mameloca e Santo Antônio da Mameloca) e já na fronteira com a Colômbia (sítio Mangueiras). Mas foi Hilbert que realizou as primeiras escavações, privilegiando locais estratégicos como desembocadura de rios e lagos para a coleta de superfície e subsuperfície. Suas observações assinalaram a existência de grandes sítios formados por terra preta. No lago Tefé sete sítios arqueológicos foram registrados

\footnotetext{
16 A presença dos Kaixana na região é antiga e bastante documentada (Fritz, 1922 [1697]; Sampaio, 1985 [1775]; (Spix \& Martius, 1981 [1889]; Porro, 1995; Itacarambi, 2006). No mapa etnolinguístico de Nimuendaju, estavam classificados como pertencentes ao tronco Arawak, falando uma língua já extinta durante o século XIX.
} 
próximos a sua desembocadura. No lago Caiambé, a $40 \mathrm{~km}$ a jusante de Tefé, um único sítio foi identificado casualmente, através da observação de uma área desbarrancada, fenômeno bastante comum conhecido como "terras caídas", produto da dinâmica de erosão do rio Solimões (Hilbert, 1968). Foi a partir das intervenções nesse sítio que as fases Caiambé e Tefé foram criadas, e respectivamente, inseridas nas tradições Borda Incisa e Polícroma da Amazônia, se relacionando com a cronologia da ocupação da Amazônia Central proposta por Meggers e Evans (1961).

Havia na época uma cronologia para a Amazônia baseada nas seriações cerâmicas, que indicava a ocorrência de quatro horizontes estilísticos, ora transformados em tradições, que estabelecia a seguinte sequência (do mais antigo ao recente): Zonado-hachurado, Borda Incisa, Polícromo da Amazônia e Inciso Ponteado. A tradição Borda Incisa era a mais hipotética neste quadro se estendendo entre 100 e 800 d.C. Os trabalhos de Hilbert ofereceram maior caracterização e identificação da sua distribuição geográfica pela calha do Amazonas (da confluência do Negro à foz do Japurá), quando foram criadas as fases: Paredão, Manacapuru e Caiambé. As outras intervenções realizadas por Hilbert nos sítios do alto curso do rio Solimões e no Japurá, resultaram na criação das fases Santa Luzia e Japurá, ambas não se enquadravam na tipologia das quatro tradições conhecidas (Hilbert, 1968).

A fase Caiambé foi definida com material cerâmico do lago homônimo localizado a $40 \mathrm{~km}$ a jusante de Tefé a partir da escavação de dois pontos do sítio. O autor registrou no primeiro depósito, que alcançou a profundidade de 1,20 m, um pacote de terra preta de aproximadamente $40 \mathrm{~cm}$ de espessura. A partir dos $90 \mathrm{~cm}$ de profundidade observou-se uma coloração mais clara do solo e diminuição do material arqueológico. O segundo depósito com $60 \mathrm{~cm}$ de profundidade, embora menos profundo, apresentou maior quantidade de material cerâmico. O pacote de terra preta que se iniciava na superfície do terreno, ao que parece terminava abruptamente no contato com o solo de matriz argilosa característico da região.

A fase foi caracterizada em seis estilos diferentes que elucidam sua variabilidade, que será detalhada no capítulo 4. As cerâmicas possuíam cauixi como antiplástico principal, além da mistura com o caraipé. Características decorativas importantes eram as incisões duplas, modelado, engobo vermelho, além da pintura polícroma. É especialmente interessante a criação de um estilo policromo nesta fase, que na seriação de Hilbert se mantem estável em toda sequência estratigráfica. Com as datações de $640 \pm 60$ e $730 \pm 60$ 
d.C e o estilo decorativo com ênfase nas incisões, Hilbert insere a fase na Tradição Borda Incisa, contemporânea à fase Manacapuru (Hilbert, 1962a).

\begin{tabular}{|c|c|c|}
\hline \multicolumn{2}{|c|}{ Estilos } & Características decorativas e observações gerais \\
\hline \multirow{6}{*}{ 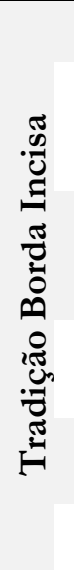 } & Caiambé s/ dec. & Estilo mais comum observado nos depósitos escavados \\
\hline & $\begin{array}{l}\text { Caiambé incisão } \\
\text { fina }\end{array}$ & $\begin{array}{l}\text { Linhas paralelas com espessura entre } 1 \text { e } 4 \mathrm{~mm} \text {, em sua maioria } 2 \mathrm{~mm} \text {, } \\
\text { localizadas nas bordas e com vários formatos, diagonal, oblíquo, espiral e } \\
\text { curvo. }\end{array}$ \\
\hline & $\begin{array}{l}\text { Caiambé incisão } \\
\text { dupla }\end{array}$ & $\begin{array}{l}\text { Apresenta decoração incisa feita a partir de instrumento com ponta dupla, } \\
\text { com espessura de } 5 \mathrm{~mm} \text {, apresentando motivos em zigue-zague, } \\
\text { ondulado e diagonal. }\end{array}$ \\
\hline & $\begin{array}{l}\text { Caiambé pintura } \\
\text { vermelha }\end{array}$ & $\begin{array}{l}\text { a pintura se apresenta em camadas muito finas, geralmente na face } \\
\text { externa da cerâmica. Encontrado nos níveis estratigráficos mais antigos }\end{array}$ \\
\hline & Caiambé polícroma & $\begin{array}{l}\text { Pintura vermelha e/ou preta sobre engobo branco. Encontrado na } \\
\text { mesma proporção em todas as camadas estratigráficas }\end{array}$ \\
\hline & Caiambé modelada & $\begin{array}{l}\text { Vasos sem decoração ou com incisões simples, mas modelados e bordas } \\
\text { recortadas. }\end{array}$ \\
\hline
\end{tabular}

Tabela 1: Síntese dos estilos da fase Caiambé.

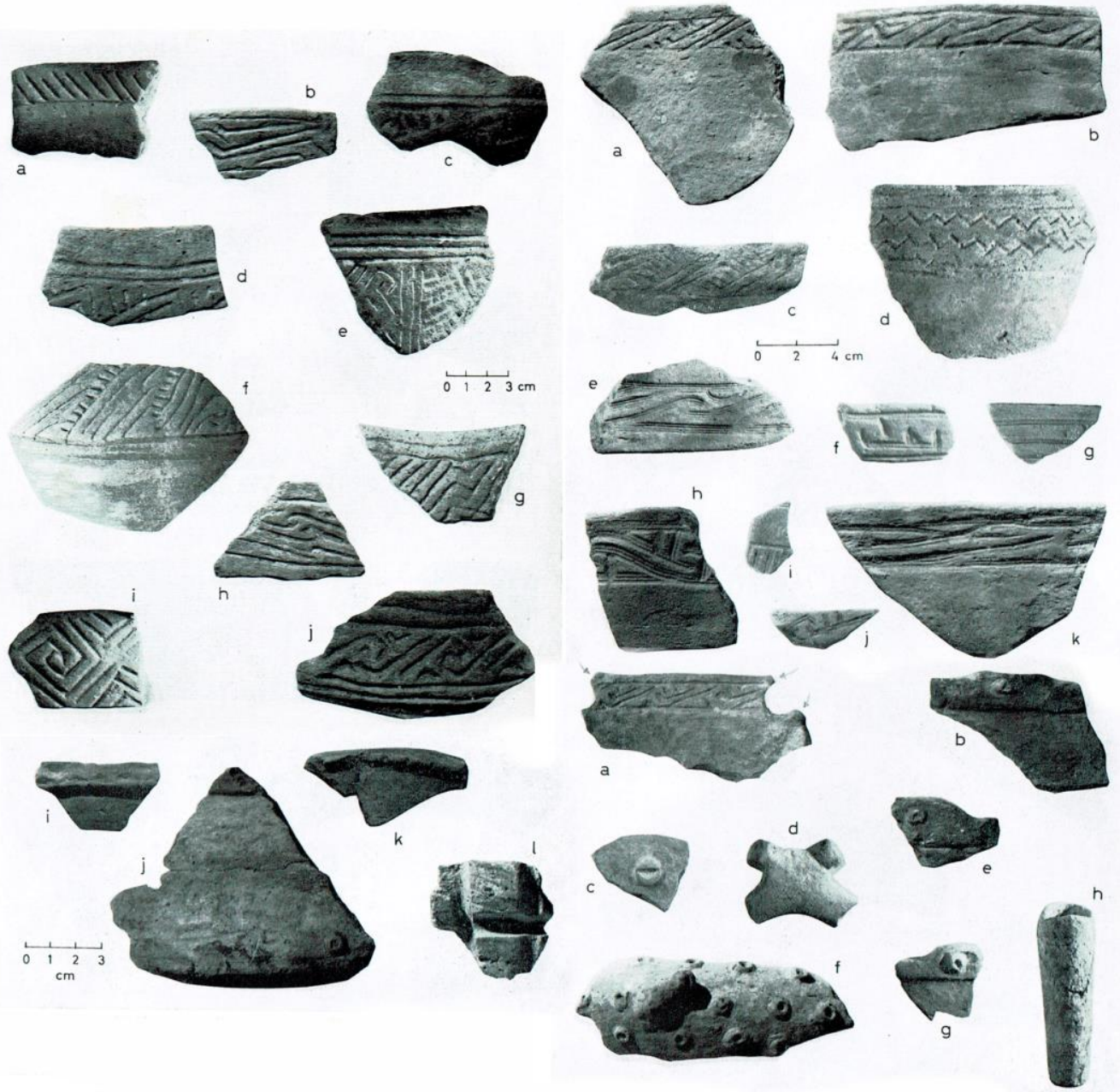

Figura 6: Cerâmicas da Fase Caiambé (Hilbert, 1968) 
A fase Tefé foi incorporada à Tradição Polícroma da Amazônia devido às semelhanças compartilhadas com a fase Guarita que permitiram a situar cronologicamente entre 900 a 1300 d.C. Tinha como característica principal o predomínio do caraipé como antiplástico apesar de uma porção menor do material apresentar a mistura caraipé e cauixi. Foram definidos três estilos para essa fase que seria encontrada também em sítios da desembocadura ao médio curso do rio Japurá (Hilbert, 1962a).

\begin{tabular}{|c|c|c|}
\hline & Estilo & Características decorativas e observações gerais \\
\hline \multirow{3}{*}{ 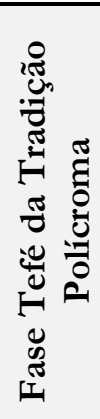 } & $\begin{array}{l}\text { Tefé s/ } \\
\text { decoração }\end{array}$ & $\begin{array}{l}\text { Apresenta lábio reforçado e flanges mesiais, Semelhantes a sub-tradição } \\
\text { Guarita }\end{array}$ \\
\hline & $\begin{array}{l}\text { Tefé } \\
\text { excisão } \\
\text { larga }\end{array}$ & $\begin{array}{l}\text { Linhas simples ou compostas por cinco ou mais linhas paralelas com } \\
\text { espessuras variando entre } 3 \text { e } 8 \mathrm{~mm} \text { com aproximadamente } 2 \mathrm{~mm} \text { de } \\
\text { profundidade. Em alguns casos há presença de engobo branco tanto nas } \\
\text { paredes dos vasilhames quanto nas excisôes. Este estilo de decoração é } \\
\text { predominante na fase Tefé. }\end{array}$ \\
\hline & $\begin{array}{l}\text { Tefé } \\
\text { Polícroma }\end{array}$ & $\begin{array}{l}\text { Presença de flanges mesiais com decoração excisa. Pintura vermelha e/ou } \\
\text { preta sobre engobo branco semelhante à policromia encontrada na cerâmica da } \\
\text { sub-tradição Guarita }\end{array}$ \\
\hline
\end{tabular}

Tabela 2: Síntese dos estilos da fase Tefé

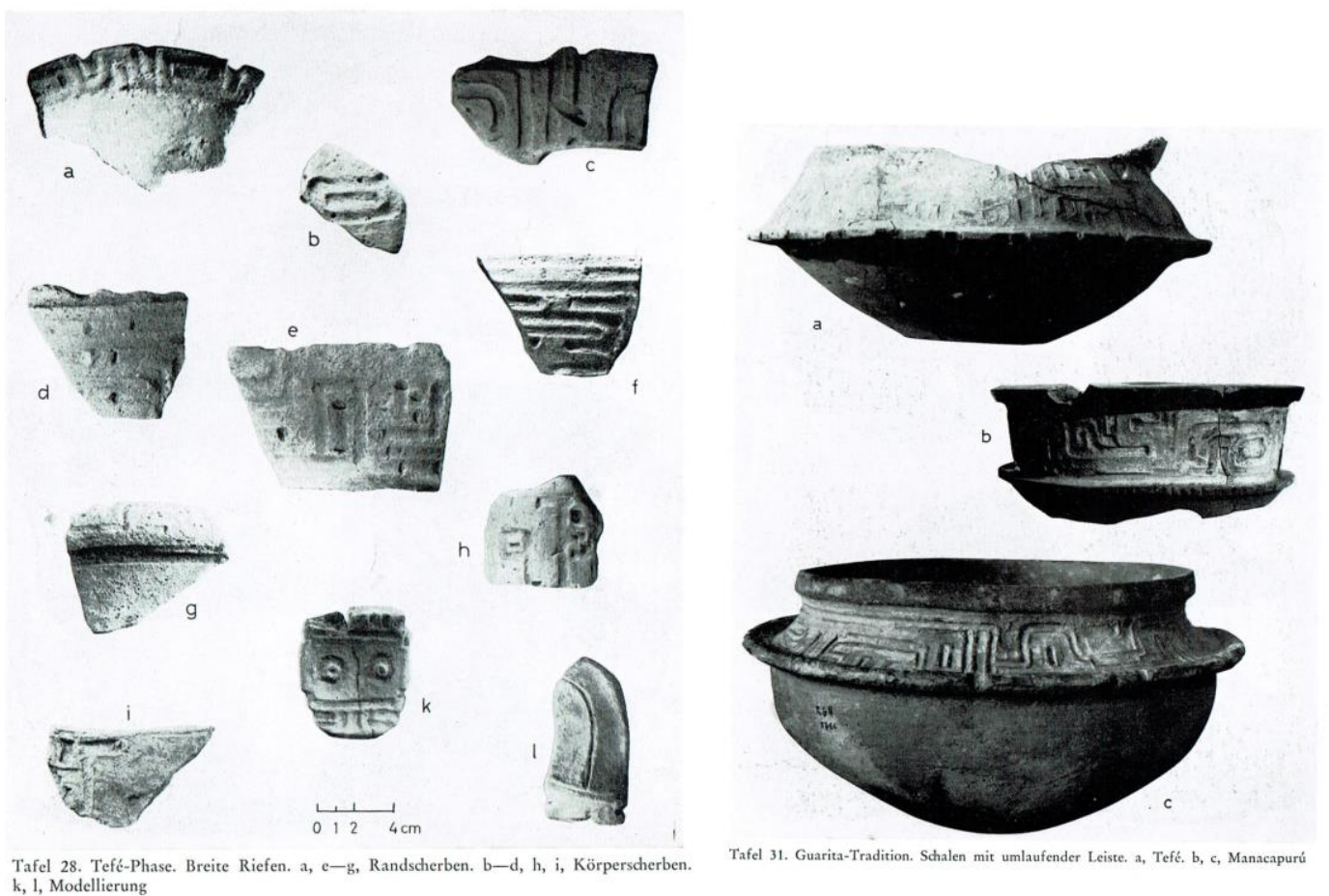

Figura 7: Cerâmicas da Fase Tefé (Hilbert, 1968)

Hilbert fez apontamentos sobre uma sequência de transição gradual de uma fase para a outra nos sítios dos lagos Tefé e Caiambé, ao observar o uso concomitante dos antiplásticos cauixi e caraipé bem como a presença constante de policromia. É interessante notar que no primeiro momento o autor considera as cerâmicas das camadas mais superficiais influenciadas pela Tradição Polícroma (Hilbert, 1962a), e apenas posteriormente, confirmou a existência de um conjunto polícromo (Hilbert, 1968). 
No Japurá Hilbert iniciou seu levantamento a partir de Mapari, no médio curso do rio. Os sítios possuíam elementos da Tradição Polícroma, embora a cerâmica fosse temperada com cauixi, foram observados pintura em vermelho e preto no branco, acanalados em flanges em torno da área do diâmetro máximo do corpo de tigelas abertas, e o modelado, limitado a urnas funerárias antropomórficas. "É uma cultura com a mesma tradição cerâmica relacionada à fase de Tefé, que pode ser encontrada na maioria dos locais em torno da foz do Japurá, bem como em torno de Tefé.” (Hilbert, 1962 b:465, tradução nossa).

O Sítio Mangueiras, localizado já na fronteira com a Colômbia, teria sido o único que ofereceu profundidade suficiente para escavação estratigráfica. Foram realizados dois cortes em depósitos de terra preta e uma extensa coleção de superfície (Hilbert, 1962b:466). O material foi classificado em cinco estilos decorativos, e a principal característica da fase seria a ênfase nas modelagens, utilizadas, sobretudo, nas bordas dos vasos, além da presença de pintura vermelha em diferentes tons sobre uma base branca.

Estilos Características decorativas e observações gerais

\begin{tabular}{ccl}
\hline & Japurá s/ dec. & Presente em toda fase Japurá \\
& Japurá & Presença de engobo vermelho em ambas faces dos vasilhames. Encontrado \\
principalmente no período médio de ocorrência da fase Japurá
\end{tabular}

Tabela 3: Síntese das características da fase Japurá

Para a fase Japurá há apenas uma datação absoluta de 635 d.C. Diante das variações formais observadas no conjunto, que não indicavam qualquer tendência particular, Hilbert 
sugeriu que a fase seria correspondente a uma única ocupação de duração relativamente curta (op. Cit, p. 470).

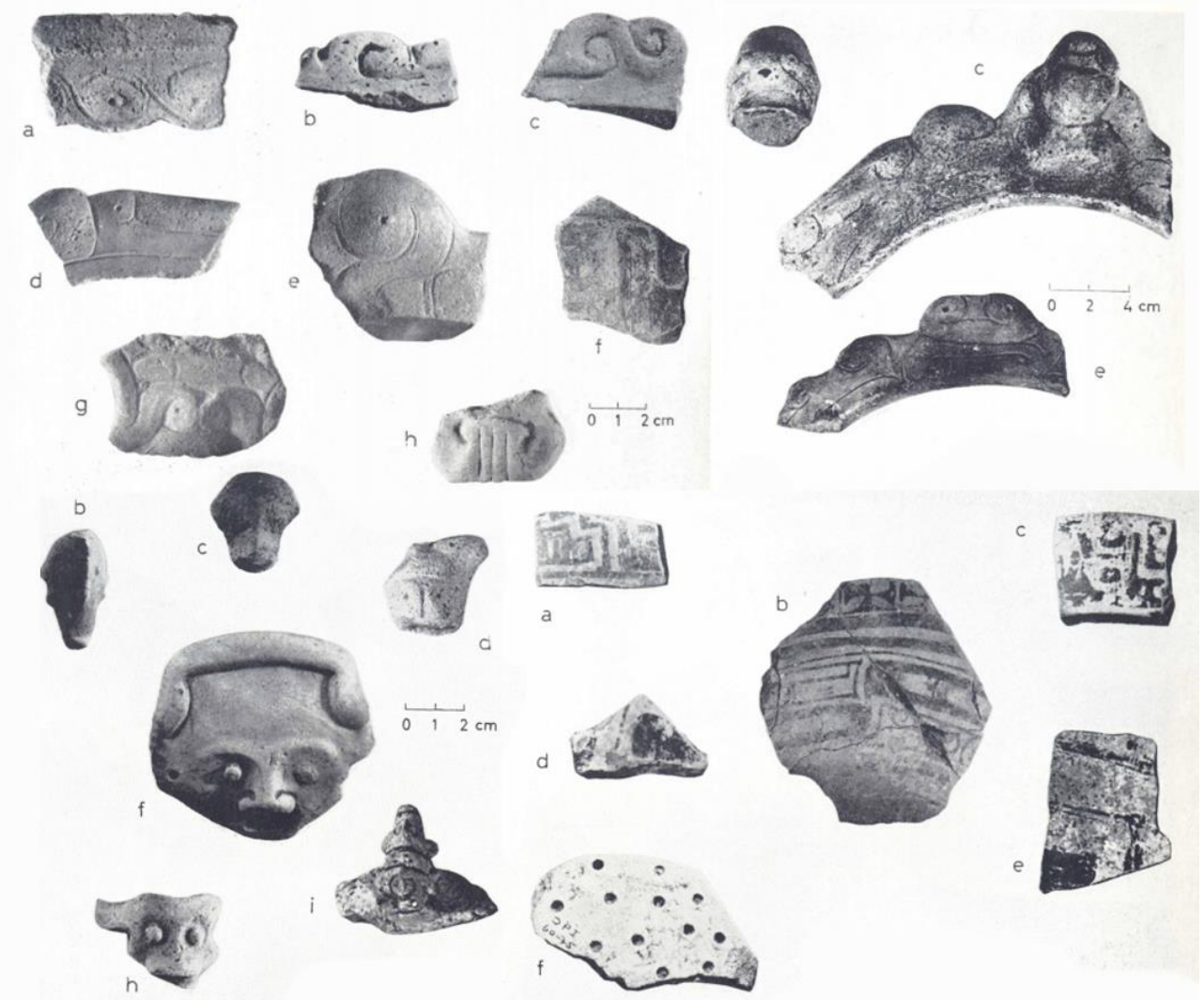

Figura 8: Cerâmicas da fase Japurá (Hilbert, 1968)

Todas essas informações foram consideradas na publicação sobre a distribuição das cerâmicas polícromas de Meggers e Evans (1968:97-98), caracterizando a região do Japurá como uma via das rotas de difusão do estilo polícromo dos Andes para a Amazônia, portanto corroborando uma expansão de grupos policromos de oeste para leste (ibdem, 106). Contudo, de acordo com o próprio Hilbert, o material trazia reminiscências das cerâmicas Barrancóides, comuns no Rio Orinoco (Hilbert, 1962 b; Cruxent e Rouse, 1957). Essa observação foi reafirmada posteriormente na sua publicação onde define a fase Pocó, quando salienta as semelhanças entre esses complexos (Hilbert e Hilbert, 1980), e o que foi corroborado por Meggers e Evans:

"o único complexo cerâmico amazônico que com segurança pertence a este período [500 -1000 d.C] e não está filiado a Tradição Polícroma é a fase Japurá. Ainda que registrada a pintura, sua cerâmica se distingue por suas vasilhas com bordas alargadas e decoradas com modelado e incisão, reminiscentes do estilo Barrancóide. Tanto a proximidade desta região com o médio Orinoco, a existência de uma conexão hídrica entre as redes do Orinoco e Amazonas como as diferenças na antiguidade, é provável uma derivação do norte. (Meggers e Evans, 1977:36, tradução nossa) 
A interpretação de Hilbert sobre curta duração de ocupação no sítio por ele escavado é oposta aquelas produzidas por pesquisadores que trabalharam no rio Japurá/Caquetá décadas depois, já em território colombiano. Os sítios do médio e baixo Caquetá são tratados como de assentamentos relativamente grandes e duradouros. Cerca de $50 \mathrm{~km}$ de Mangueiras está localizado o sítio La Pedrera. Ele foi registrado primariamente pelo missionário Tastevin, sendo o mais importante sítio arqueológico próximo à fronteira do Brasil e Colômbia, famoso por seus petroglifos (Tastevin, [1923] 2008: 184). Elizabeth Reichel von Hildebrand foi a pesquisadora que na década de 1970 atuou na região, realizando sua caracterização arqueológica (Reichel von Hildebrand, 1975). Segundo suas observações o sítio apresenta manchas de terra preta cuja espessura pode atingir entre 40 e $60 \mathrm{~cm}$. A partir da analise de uma coleção de superfície, as cerâmicas de La Pedrera se caracterizam pela presença de pintura, incisões e dos apliques modelados, de modo que a autora pontua a grande semelhança entre essas cerâmicas e aquelas apresentadas por Hilbert para a fase Japurá, sugerindo suas possíveis correlações (Reichel von Hildebrand, 1976:161).

A região de Araracuara, já no médio curso do rio Caquetá, próximo a desembocadura do rio Yari, tem seu contexto arqueológico bastante conhecido. Ainda na década de 1970, iniciou-se na região inúmeros trabalhos em torno das características físicas e químicas da terra preta, sua associação cultural, processos de formação, mudanças na vegetação associadas a práticas agrícolas, etc (Andrade, 1986; Andrade e Botero, 1984; Cavelier, 1995; Eden, 1982; Eden et al, 1984; Eidt, 1977; Herrera et al, 1988; Herrera et al, 1992; Mora et al, 1991; Oyela-Caycedo, 1999). Com mais de 22 sítios conhecidos, os estudos indicam amplo uso do solo com uma longa duração da tradição local Camani, definida por Herrera et al (1982) e encontrada em estratos de 30 a $70 \mathrm{~cm}$ de profundidade associada a terra preta. O material apresenta pouca variabilidade formal e rara decoração, com presença de grandes vasos com bordas ampliadas e engobadas em vermelho. As informações indicam que as cerâmicas Camani tem início por volta de $2.740 \pm 70 \mathrm{BP}$

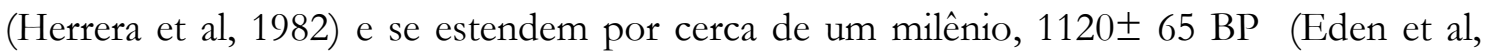
1984: 134; Myers, 2004:81.

Naquela região, a Tradição Polícroma da Amazônia é representada pela Fase Nofurei, encontrada em níveis superficiais de sítios multicomponenciais e unicomponenciais com presença de terra preta (Herrera et al, 1982). Eden e colaboradores (1984:137) pontuam que nos sítios estudados por eles, a maior densidade cerâmica na terra preta está associada a fase Nofurei, embora a fase Camani, estivesse presente nos níveis 
mais profundos. As datas situam o estilo Nofurei no período: 705 60 BP ou 1245 d.C (Beta-1506) e 350 50 BP ou 1.610 d.C. (Beta-1510) (Eden et al, 1984:135; Herrera, 1987; Myers, 2004:81).

Após um hiato nas pesquisas arqueológicas na região de Tefé, em 2001 iniciou-se o levantamento de sítios na região do baixo Japurá, no lago Amanã, para a formulação do Plano de Gestão e Manejo de recursos da RDS Amanã (Cf Capítulo 3). A partir de 2011, o próprio lago Tefé passou a ser foco de um projeto de mapeamento com interesse específico nas cerâmicas da Tradição Policroma da Amazônia. Foram registrados 31 sítios, dentre esses se destacam 4 sítios contíguos localizados próximo à desembocadura do lago, o Conjunto Vilas, um sitio com aproximadamente 38 ha, multicomponencial, cujo componete cultural mais expressivo é da fase Caiambé.

As análises cerâmicas demonstram um alto grau de compartilhamento de técnicas decorativas e de manufatura entre as tradições Borda Incisa e Polícroma da Amazônia, não apenas no que se refere aos objetos de uso contidiano, escavados em contexto de terra preta com ínumeras estruturas (feições), mas também em objetos de conotação ritual e cerimonial, como estatuetas (Figura 9 a). As datas obtidas através de amostras de fragmentos cerâmicos considerados por Belleti como diagnósticos da fase Tefé, recuaram a presença da Tradição Polírcoma na região, com datas de 440 e 450 d.C (Figura 9 f), já a terceira data de 1070 d.C, de um fragmento de flange, típica da fase, é coerente com a cronologia das hipóteses que serão apresentados a seguir. Abaixo, na tabela 4, estão todas as mais recentes datações para a fase Tefé na região de Tefé, nela além do sítio Conjunto Vilas, duas datas do sítio cemitério Tauary, localizado na extremidade oposta do lago Tefé, onde foram coletadas 6 urnas funerárias antropomorfas. Neste sítio, ambas as datas próximo ao contato e em período colonial.

Sítio Proveniência Prof. Conv. Rad.Age $\quad \mathbf{N}^{\circ}$ Lab.

\begin{tabular}{l|llll}
\hline Conj. Vilas & $\begin{array}{l}\text { S1068E1450. } \\
\text { Cerâmica/ Caraipé. }\end{array}$ & $80-90 \mathrm{~cm}$ & $1.620 \pm 30 \mathrm{BP}$ & Beta-406074 \\
\hline Conj. Vilas & $\begin{array}{l}\text { S1068E1450. } \\
\text { Cerâmica /Caraipé }\end{array}$ & $20-30 \mathrm{~cm}$ & $1.610 \pm 30 \mathrm{BP}$ & Beta-406075 \\
\hline Conj. Vilas & $\begin{array}{l}\text { S450E1651.Terra preta. } \\
\text { Carvão }\end{array}$ & $92 \mathrm{~cm}$ & $1.050 \pm 30 \mathrm{BP}$ & Beta- 406076 \\
\hline Conj. Vilas & $\begin{array}{l}\text { S1410E1651. Feição } \\
\text { Carvão. }\end{array}$ & $50-60 \mathrm{~cm}$ & $970 \pm 40 \mathrm{BP}$ & Beta-386835 \\
\hline Tauary & $\begin{array}{l}\text { Fragmento de urna } \\
\text { antropomorfa }\end{array}$ & $50 \mathrm{~cm}$ & $490 \pm 30 \mathrm{BP}$ & Beta-386878 \\
\hline Tauary & $\begin{array}{l}\text { Fragmento de urna } \\
\text { Antropomorfa }\end{array}$ & $50 \mathrm{~cm}$ & $320 \pm 30 \mathrm{BP}$ & Beta-386837 \\
\hline
\end{tabular}

Tabela 4: Datações para a Tradição Polícroma no Lago Tefé. Extraído de Belletti, 2015. 


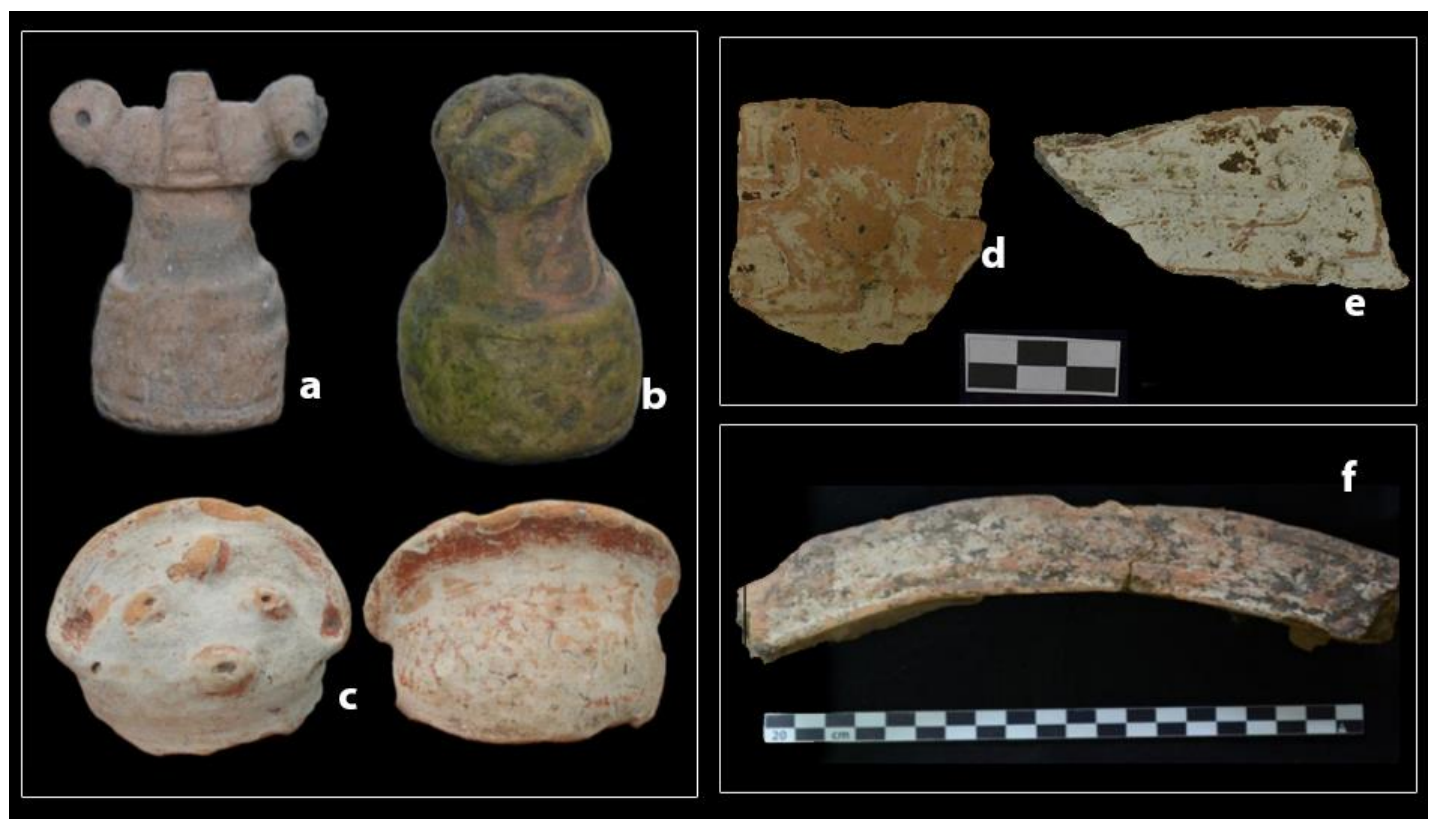

Figura 9: Materiais associados às fases Caiambé e Tefé. Fotos: Jaqueline Gomes e Jaqueline Belletti.

Belletti (2015), diante dos contextos e cerâmicas do sítio Conjunto Vilas recorre à noção de fluxo para explicar a multicomponencialidade do sítio, de modo a destacar, não uma ocupação da fase Tefé, específica e distinta sucedendo estratigraficamente ocupações da fase Caiambé, mas sim o contato direto entre as populações que estavam produzindo tais cerâmicas. Ainda que necessária uma maneira mais precisa de demonstrar tais fluxos estilísticos, os recentes esforços de pesquisadores que atuam na região caminham nesse sentido (Belleti, 2015 b; Oliveira, 2014).

2. Arqueologia da Amazônia Central e seus modelos de história cultual

O padrão de formação de grandes sítios e solos antrópicos no rio Japurá/Caquetá parece ser semelhante ao observado na Amazônia Central, onde a base de dados empíricos é maior e a cronologia de ocupação mais refinada (Neves et al, 2003; Petersen et al , 2001).

Os dois modelos de ocupação humana mais importantes na arqueologia amazônica dialogaram densamente com antropologia ecológica. Superados os determinismos e mudanças ambientais de Meggers $(1987 ; 1992)$ e a "revolução neolítica" nas várzeas amazônicas no modelo cardíaco de Lathrap (1970), um caminho para compreender as relações entre homem e ambiente, é encontrado na ecologia histórica (Neves e Rostain, 2012). Nesse paradigma, aceito por grande parte dos cientistas sociais que atuam na região, as condições ambientais são entendidas como um quadro ecológico complexo, no qual é atribuída grande importância à ação humana na constituição das paisagens amazônicas. Parece cada vez mais clara uma fluidez das formas de ocupação da Amazônia pré-colonial, 
expressa não somente nos conjuntos artefatuais, mas também nas relações com o ambiente natural (Neves, 2014).

Embora as relações entre língua e cultura material tenham sido debatidas de modo intenso na teoria arqueológica, e abnegadas pela arqueologia processual durante grande parte da segunda metade do século XX, na Amazônia, elas moveram as hipóteses de ocupações e suas revisões. A associação entre cerâmicas modeladas e falantes arawak, feita ainda no início do século passsado, é um exemplo notório desse esforço da arqueologia da região (Nordenskiold, 1930), tal qual a correlação de cerâmicas policromas e os falantes do tronco Tupi (Métraux, 1930; Lathrap, 1970; Brochado, 1984).

A área de confluência dos rios Negro e Solimões é hoje considerada uma das regiões arqueologicamente mais bem caracterizadas da bacia Amazônica devido as pesquisas de caráter multidisciplinar realizadas no âmbito do Projeto Amazônia Central que buscaram testar as hipóteses de ocupação vigentes (Castro, 2009; Chirinos, 2006; Donatti, 2003; Lima, 2008; Machado, 2006; Moraes, 2006; Neves \& Petersen, 2005; Neves, 2010; 2000; Neves et al., 2003b; Rapp Py-Daniel, 2009).

Com a revisão e refinamento da cronologia da região, sabe-se que ocupações ceramistas se iniciam em torno de 400 a.C. com a tradição Pocó-Açutuba e se estende por metade do primeiro milênio da Era Cristã. A fase Açutuba, associada a matrizes de solos anteriores a terra preta, apresenta cerâmicas com variabilidade morfológica e diversificação no uso de antiplásticos. A decoração é realizada com várias técnicas com destaque das modelagens, incisões e excisões, sua principal distinção tecnológica em relação a Tradição Borda Incisa é o uso de pintura polícroma com várias tonalidades de vermelho, vinho, laranja e/ou preto aplicadas sobre engobo branco. As datações disponíveis situam a cerâmica Açutuba entre 400 a.C - 400 d.C. - período em que na bacia dos rios Nhamundá e Trombetas, são encontradas cerâmicas Pocó entre 360 a.C. a 380 d.C (Guapindaia, 2008; Hilbert \& Hilbert, 1980). A fase se caracteriza pela diversidade decorativa além da policromia das cerâmicas em sítios de ambiente ribeirinho, compostos por terra preta e bolsões nas camadas mais profundas dos depósitos - contextos exclusivos de ocorrência da fase.

Além das relações estilísticas é possível dizer que também em termos contextuais as cerâmicas Pocó guardam semelhanças com as cerâmicas Açutuba (Guapindaia, 2008; Lima et al, 2006; Lima, 2010). As informações sugerem um antigo horizonte de ocupação na calha do Rio Amazonas relacionado às evidencias mais claras de um modo de vida sedentário no primeiro milênio a.C (Neves, 2001; Neves et al, 2014). 
A intensificação da presença dos solos antrópicos é um fenômeno interpretado na Arqueologia da Amazônia Central como indicador do aumento da densidade populacional, quando sociedades mais sedentárias tornam-se comuns no registro arqueológico (Neves et al., 2003, 2004; Neves, 2011; Petersen et al., 2001). Esse marcador cronológico e cultural no tem estreitas ligações com as ocupações associadas às cerâmicas da fase Manacapuru, com sítios a partir de 400 d.C. com contextos unicomponenciais e multicomponenciais formados por extensos e profundos pacotes de terra preta (Lima, 2008; Neves, 2010).

Nas cerâmicas da fase Manacapuru a decoração é feita essencialmente com técnicas de modelagem e incisões e a principal característica são os flanges labiais normalmente usados como suporte para decoração (Hilbert, 1968; Lima, 2010). Em torno de 700 d.C parece haver um apogeu demográfico no qual as populações imprimiram mudanças mais visíveis na paisagem como a construção de montículos artificiais (Castro, 2009; Machado, 2005; Moraes, 2006). Há um alto controle tecnológico nas cerâmicas Paredão que apresentam baixa variabilidade formal e decoração menos destacada com ênfase nas incisões e na pintura vermelha com motivos geométricos em espiral e em gregas. Também bastante diagnósticos são os apêndices antropomorfos - conhecidos como cabecinhas aplicados nas urnas funerárias (Hilbert, 1968; Moraes, 2006; Rapp Py-Daniel, 2009).

A cronologia mostra interpolações entre as fases Manacapuru e Paredão que apesar de particularidades na cultura material compartilham um formato circular ou semi-circular de suas aldeias (Chirinos, 2006; Donnati, 2002; Moraes 2006; 2010, Neves 2008). No período entre 600 e 1.200 d.C., a quantidade e o tamanho dos sítios sugerem que a região acolhia uma grande população provavelmente de etnias distintas, mas entrelaçadas por uma forte rede de interação (Lima, 2008; 2010; Neves, 2007; 2011b; Heckenberger \& Neves, 2009).

As relações entre as Tradições Pocó-Açutuba e Borda Incisa na Amazônia Central foram interpretadas a luz das continuidades culturais, que se expressam não apenas em elementos tecnológicos da produção cerâmica, mas na sobreposição de camadas culturais nos pacotes de terra preta e formato de aldeias. Após o período de um milênio de ocorrência dessas tradições, a presença de vasos com uma tecnologia e decoração fundamentalmente diferentes passa a ser predominante. Tais cerâmicas são classificadas como pertencentes à Tradição Polícroma da Amazônia, que na região é representada pela fase Guarita e ocorrem em sítios que apresentam depósitos superficiais e com um possível padrão de organização linear dos assentamentos (Tamanaha, 2012; Rebellatto, 2008). 
No médio Solimões, próximo a cidade de Coari e rio Urucu, as análises de Tamanaha (2012), destacam uma variabilidade tecnológica nas cerâmicas da tradição Polícroma, mas certa rigidez da constituição das morfologias e acabamento dos vasos. As relações entre essas diferentes Tradições cerâmicas têm sido interpretadas sob o tema da guerra em virtude dos vestígios de paliçadas e valas encontradas em sítios associados à Tradição Borda Incisa em torno do ano 1000 d.C. (Neves, 2008).

Portanto, as pesquisas conduzidas por Neves e colaboradores, trouxeram novos dados e muitas das hipóteses dos modelos vigentes não foram confirmadas na Amazônia Central:

i) A agricultura, que seria a chave para o adensamento populacional no modelo cardíaco, não parece ser o principal elemento das economias pré-coloniais. A recuperação de micro e macrovestígios, as análises faunísticas e de isótopos, destacam a diversificação na alimentação dessas populações, com uma dieta baseada em plantas selvagens e semi-domesticadas, peixes, repteis, e secundariamente, os cultivares, como mandioca e milho (Shock et al, 2013 Caromano, 2010; Carneiro, 2012; Cascon, 2010).

ii) As cerâmicas não são antigas como Lathrap propunha ${ }^{17}$, ocorrendo as primeiras produções cerca de 400 a.C (Lima, 2008), As Tradições Borda Incisa e Polícroma, respectivamente relacionadas as línguas Arawak e Tupi, vistas por ele em termos de continuidades, têm na verdade, uma transição abrupta, especificamente expressa em padrões distintos de organização das aldeias e tecnologia cerâmica (Machado, 2006; Tamanaha, 2012), cujos contextos indicam relações conflituosas em alguns sítios (Moraes, 2010; 2013; Neves, 2013; Moraes e Neves, 2012). Por outro lado, as reocupações dos sítios são comuns, mas não necessariamente curtas como Meggers supunha.

iii) Por fim, embora iniciadas ainda no primeiro milênio a.C, ocupações ceramistas na calha do Amazonas, parecem ser resultados de colonização de áreas por populações exógenas, como Meggers e Evans pontuaram.

Mas se o modelo cardíaco não se confirma em toda sua dimensão, um aspecto parece, ao contrário, ser mais robusto: a associação entre línguas Arawak e cerâmicas incisas modeladas. Pois agora outros correlatos arqueológicos, que não apenas a cultura material podem ser considerados no debate. Heckenberger (2002) a partir de suas pesquisa no Alto Xingu destaca como elementos de um ethos Arawak

i) aldeias de formato circular - cujo padrão foi nitidamente associado à ocupação dos grupos Arawak no Caribe insular (Petersen et al. 1996); no Alto Xingu (Heckenberger, 2005) e também no registro arqueológico da Amazônia central (Neves, 2013; Chirinos, 2007, Moraes, 2013) e baixo Amazonas (Guapindaia e Fonseca, 2013; Neves et al, no prelo) associadas às cerâmicas inciso modeladas da Tradição Borda Incisa e Pocó-Açutuba.

\footnotetext{
${ }^{17}$ Nas periferias da Amazônia começa a emergir um padrão de ocupações mais antigas, com profundas e extensas camadas de terra preta, em contextos ecológicos distintos e com cerâmicas antigas mas sem relações estilísticas entre si (Neves, 2014).
} 
ii) regionalidade, embora os parâmetros para a visibilidade arqueológica de sistemas regionais ainda não sejam claros (Neves, 1999), e baseados na cultura material, cuja permanência e continuidade de elementos tecnológicos e simbólicos são índices de redes e esferas de interação (Lima, 2008).

iii) Sedentarismo, que não depende exclusivamente do desenvolvimento de agricultura (como vem sendo demonstrado no registro da Amazônia Central), mas pode ser entendido em termos de sistemas agroflorestais e tecnologia de manejo florestal.

Esse ethos Arawak é ainda caracterizado, etnologicamente, por outros elementos de baixa visibilidade arqueológica, mas relevantes: como a negociação interétnica, disputa e incorporação em uma vasta rede de intercâmbio com comércio, casamentos mistos e uma interação cerimonial elaborada (Hornborg e Ericksen, 2011). Fato é que as expansões Arawak são entendidas como "diásporas", envolvendo relações históricas com diferentes famílias linguísticas - Carib, Tukano, Pano e Tupi -, resultando em contextos multilinguísticos distintos (Hill e Santos-Granero, 2002; Hill, 2002). É nesse sentido que o conceito de área cultural foi atualizado de modo a ser uma ferramenta analítica para a compreensão das singularidades regionais, que são antes históricas que genéticas, e, portanto, dependentes de elementos geográficos, ecológicos e sociológicos (Hill, 2002; Urban e Sherzer, 1988:297).

Os primeiros sinais de mudanças antrópicas na calha do Amazonas são acompanhadas das cerâmicas da Tradição Pocó-Açutuba, ainda no primeiro milênio a.C. associadas aos falantes Arawak, combinando um processo de mudança lento, mas cumulativo, relacionado às ocupações da Tradição Borda Incisa (Neves et al, 2014). No baixo Madeira as cerâmicas Axinim em contextos de ocupações datadas do século II d.C, são semelhantes a fase Paredão (Moraes, 2013; Moraes \& Neves 2012). Essas informações sugerem que em meados do primeiro milênio d.C, grupos que produziam cerâmicas Paredão iniciaram sua ocupação da Amazônia central, já habitada por grupos da fase Manacapuru. Neves (2013: 197) destaca que tais grupos, incialmente distintos, eventualmente conduziram ao desenvolvimento de um sistema regional multiétnico com circulação de cerâmicas e compartilhamento de uma mesma cosmologia baseada na ocupação de aldeias circulares.

Essa dinâmica não parece ter sido a mesma quanto ao surgimento e expansão da Tradição Polícroma na calha do Amazonas, que segundo os modelos atuais, foi relativamente rápida, envolveu conflitos e disputas por territórios (Moraes, 2013). Na Amazônia central e ocidental, há um padrão cronológico, no qual datas situadas em 
meados do primeiro milênio d.C estão no alto Madeira tornando-se mais recentes no seu baixo curso (Almeida, 2013). Já na foz do Madeira as datas são do século IX d.C, na confluência do Negro e Solimões por volta do ano 1000, e já no alto Solimões no século XIII d.C. Genericamente as datas se tornam mais recentes de leste para oeste. Contudo, apesar da relativa rapidez da dispersão dessas cerâmicas em uma escala continental, distribuídas desde o sopé dos Andes ao baixo Amazonas, quando consideradas em escala regional, as datas elucidam que tal expansão não se tratou de um processo regular e linear (Tamanaha, 2012; Neves, 2013; Tamanaha e Neves, 2014).

A associação dessa cerâmica com falantes do tronco Tupi, ganha mais força a partir dos recentes dados arqueológicos apresentados por Moraes (2013) e Almeida (2013), que caracterizam os contextos e cronologia da Tradição Polícroma, aliados aos dados linguísticos, sobre um suposto centro de origem na região do Madeira, bem como de estudos sobre estrutura gramatical no alto amazonas, que sugerem uma assimilação rápida do tupi em uma língua de estrutura arawak (Cabral, 2011; Cabral e Rodrigues, 2003). Alguns fatores permitem em certa medida, reatualizar as relações entre cerâmicas da tradição Polícroma da Amazônia e o tronco Tupi (Neves, 2013: 256-266):

i) evidências de guerras e conflitos, não exclusivamente associadas a disputas por recursos naturais, mas como aspecto de uma cosmologia;

ii) um aparente padrão explícito nas esferas ecológicas e de produção material (historicamente documentado no litoral brasileiro e observável arqueologicamente na Amazônia), sendo os locais preferenciais de ocupações Tupi ambiente florestados e a singularidade das cerâmicas pintadas

iii) mas a variação aleatória de certos domínios da cultura - como os padrões de assentamentos e formato de aldeias.

Os contextos arqueológicos na Amazônia Central, vistos em uma escala mais geral por Neves são interpretados como índices de diferentes regimes de historicidade, que por sua vez, marcam distintos ethos e cosmologias dos povos que ali habitaram na longa história de ocupação da região (Neves, 2013).

Depois de definida, a fase Caiambé não teve sua dispersão geográfica verificada, apesar de ter sido considerada por diversos autores nas formulações de rotas de migração Arawak ou em trabalho de revisões tipológicas (Lathrap, 1970; Brochado \& Lathrap, 1982; Zucchi, 2010). Para o Noroeste amazônico, na bacia do Orinoco, Zucchi (2010) oferece uma síntese sobre diferentes levas migratórias, caminhos e territórios ancestrais dos grupos 
Arawak (Vidal 1989:127; Vidal e Zucchi, 2000), e considera a fase Caiambé como um dos correlatos desses movimentos em período pré-colonial.

Mais recentemente, na bacia do rio Negro, no médio curso do rio Unini, Lima (2014) identificou um contexto de longa duração que possui possíveis relações estilísticas com a fase Caiambé, além da presença da Tradição Pocó-Açutuba naquela região. Gostaria de chamar atenção, que uma das vias de acesso ao rio Negro a partir do Solimões, é através do lago Amanã e rio Unini, uma rota de escoamento da produção gomífera no século XX, viva na memória dos moradores atuais da RDS Amanã (Alencar, 2007). Essas informações arqueológicas corroboram um argumento sobre as intensas interações culturais entre essas duas importantes bacias hídricas e dão profundidade cronológica ao uso desses caminhos fluviais.

3. Os contextos e cronologia do Lago Amanã

As ocupações no Lago Amanã de maneira geral se relacionam com o quadro acima exposto para a Amazônia Central, embora ainda não seja possível determinar as relações entre as tradições. Foram registrados até o momento 41 sítios arqueológicos distribuídos desde as cabeceiras do Lago Amanã até as margens dos lagos Urini e Castanho, principais paranãs e na margem esquerda do Rio Japurá (Costa, 2009b; Gomes, 2012; Neves et al, 2014).

A diversidade de tamanho e composição dos sítios às margens do Lago indica uma intensa ocupação da área que vem sendo conhecida através dos estudos no sítio Boa Esperança, um sítio multicomponencial que apresenta formato elíptico e uma área de aproximadamente 15 ha (Costa, 2012). Ainda foi demonstrado por Costa o formato elíptico de Boa Esperança, na qual se destaca a distribuição dos vestígios e solos antrópicos, que desde as camadas mais profundas, se mantém relativamente a mesma. Ainda que sejam necessárias análises mais específicas, é possível hipotetizar sobre um formato de aldeia que tende a ser circular. As datas disponíveis para o sítio, aliadas as informações da análise cerâmica que evidenciou transformações sutis nos aspectos decorativos e tecnológicos, complexificam um pouco as relações entre as diferentes tradições e seus respectivos produtores. Por meio de uma análise que buscou caracterizar e classificar os conjuntos cerâmicos foram identificados quatro componentes culturais.

A ocupação do sítio tem início com cerâmicas associadas às profundas feições (ou bolsões) que apresentam um estilo decorativo bastante complexo cuja característica 
principal é a aplicação de finas incisões pós-queima e uso de pintura com destaque para aplicação de finas camadas de engobo nas cores laranja, branco e vermelho (Figura 10). São cerâmicas que apresentam pastas bastante friáveis, com principal antiplástico sendo caraipé adicionado de forma abundante e com um processamento grosseiro. Por suas diferenças estilísticas e cronológicas, essas cerâmicas foram classificadas como uma fase particular denominada Amanã (Costa, 2012: 107-110), embora sua ocorrência tenha sido pontual.

O contexto de duas feições com características muito semelhantes relacionadas à densidade de material cerâmico, coloração e textura do solo foi analisado de modo mais detalhado. Observações de campo sugeriam a contemporaneidade dessas estruturas, o que foi corroborado após o tratamento das cerâmicas em laboratório.

Foram obtidas datas a partir de dois fragmentos cerâmicos da fase Amanã

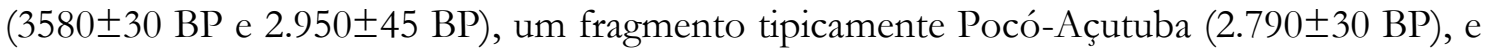
ainda, duas amostras de carvão coletadas na base e no topo das feições (Tabela 5). A partir dessas informações, interpretamos que as feições foram realizadas na ocupação PocóAçutuba para a deposição do material cerâmico anterior a ela.

No Amostra Proveniência $\quad$ Prof. $\quad$ Conv. Rad.Age $\quad \mathbf{N}^{\circ}$ Lab.

\begin{tabular}{l|llll}
\hline BOAESP205 & $\begin{array}{l}\text { S1575W1248. } \\
\text { Cerâmica/ Caraipé. }\end{array}$ & $50-60 \mathrm{~cm}$ & $1.080 \pm 30 \mathrm{BP}$ & Beta-321196 \\
\hline BOAESP203 & $\begin{array}{l}\text { S1575W1248. } \\
\text { Cerâmica /Caraipé }\end{array}$ & $30-40 \mathrm{~cm}$ & $1.220 \pm 30 \mathrm{BP}$ & Beta-321195 \\
\hline BOAESP235 & $\begin{array}{l}\text { S1623W1175. Terra } \\
\text { Preta. Carvão }\end{array}$ & $60 \mathrm{~cm}$ & $1.520 \pm 30 \mathrm{BP}$ & Beta-294193 \\
\hline BOAESP311 & $\begin{array}{l}\text { S1600W1247. Topo de } \\
\text { Feição (F3). Carvão. }\end{array}$ & $100 \mathrm{~cm}$ & $2.410 \pm 40 \mathrm{BP}$ & Beta-294195 \\
\hline BOAESP309 & $\begin{array}{l}\text { S1600W1247. Base de } \\
\text { Feição (F2). Carvão. }\end{array}$ & $170 \mathrm{~cm}$ & $2.500 \pm 40 \mathrm{BP}$ & Beta-294194 \\
\hline BOAESP15198 & $\begin{array}{l}\text { S1526W1248 Feição } \\
\text { Cerâmica/Caraipé. }\end{array}$ & $70-80 \mathrm{~cm}$ & $2.690 \pm 30 \mathrm{BP}$ & Beta-321192 \\
\hline BOAESP2831 & $\begin{array}{l}\text { S1600W1247. Feição 3. } \\
\text { Cerâmica - Caraipé }\end{array}$ & $120-130 \mathrm{~cm}$ & $2.800 \pm 30 \mathrm{BP}$ & Beta-321194 \\
\hline BOAESP2653 & $\begin{array}{l}\text { S1600W1247. Feição } 2 . \\
\text { Cerâmica - Caraipé. }\end{array}$ & $100-110 \mathrm{~cm}$ & $3.320 \pm 30 \mathrm{BP}$ & Beta-321193 \\
\hline
\end{tabular}

Tabela 5: Datas radiocarbônicas disponíveis para o sítio Boa Esperança (Costa, 2012)

A ocupação relacionada a Tradição Pocó-Açutuba se inicia por volta de 2.800 anos, outras duas datas - $2500 \pm 50 \mathrm{BP}$ e $2410 \pm 40 \mathrm{BP}$ - sugerem o uso duradouro daquele lugar na segunda metade do primeiro milênio a.C. As cerâmicas apresentam policromia, com pintura de diferentes tons de vermelho, vinho e laranja sobre engobo branco, e apresentam precisão e regularidade na maneira como é usada a pintura. São comuns rebuscados flanges labiais e pequenos flanges adicionados centímetros abaixo das bordas. A 
decoração plástica enfatiza as incisões, acanalados, ponteados e escovados além de outras técnicas como a raspagem e o corrugado. Ao longo da estratigrafia temos a formação de

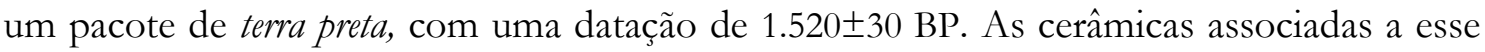
contexto mantêm elementos formais e decorativos semelhantes aos estratos mais profundos, contudo, podem ser observadas diferentes escolhas tecnológicas no que se refere ao uso predominante do cauixi e maior ênfase das técnicas plásticas de decoração(Figura 11).

De modo geral as cerâmicas demonstram muitas similaridades com as cerâmicas Pocó classificadas por Hilbert \& Hilbert (1980), compartilham algumas semelhanças contextuais com a fase Açutuba por se apresentarem em solos antrópicos claros em estratos profundos (Lima, 2008) e também a mudanças tecnológicas como aquelas destacadas por Guapindaia (2008) quando se refere à substituição de antiplástico vegetal (caraipé) pelo animal (cauixi) nas camadas de terra preta dos sítios estudados por ela.

O progressivo aumento da variabilidade formal e decorativa foi associado à fase Caiambé, que ocorre também na camada cultural mais superficial, onde são encontradas as cerâmicas da fase Tefé. Estas por sua vez, apresentam predominância do uso de caraipé como antiplástico da pasta e técnica de decoração plástica acanalada, muito comum nas paredes dos vasos que em geral formam motivos em padrões geométricos retilíneos com arredondamento dos cantos (Figura 12). As técnicas pintadas são aplicadas freqüentemente em monocromia (engobos branco e vermelho). A pintura em si é muito tímida ocorrendo em bicromia (vermelho sobre engobo branco), mas é relevante a presença de flanges mesiais com decoração plástica, diagnósticos das fases Guarita e Tefé (Hilbert, 1968; Tamanaha, 2012). 


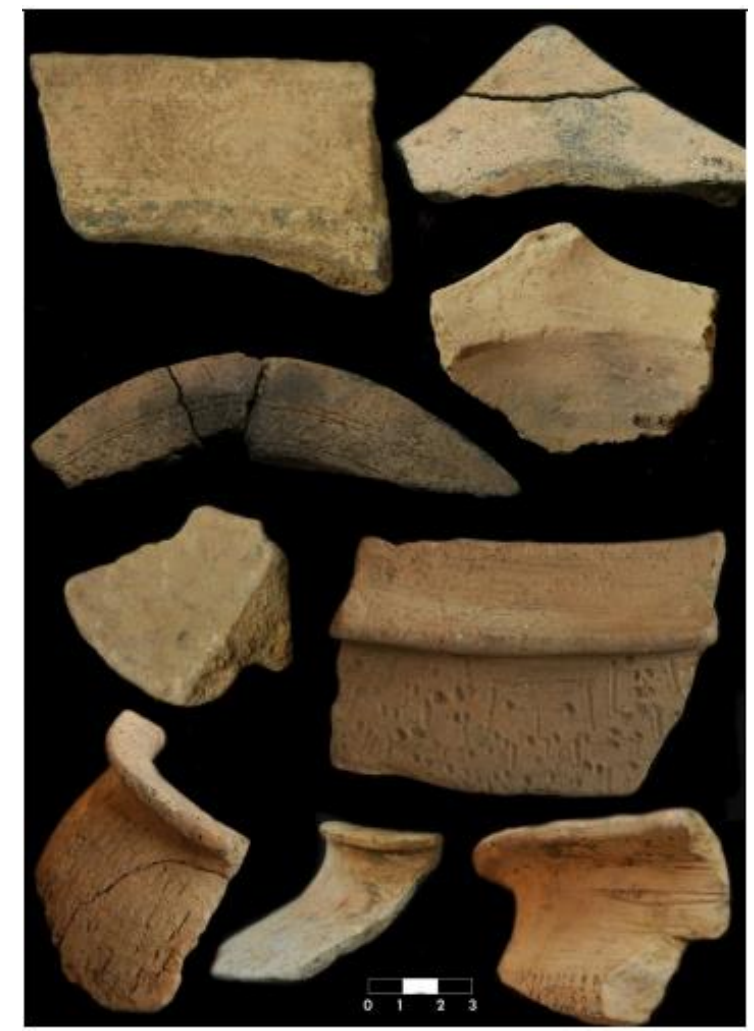

Figura 10: Fragmentos da Fase Amanã no sítio Boa Esperança.

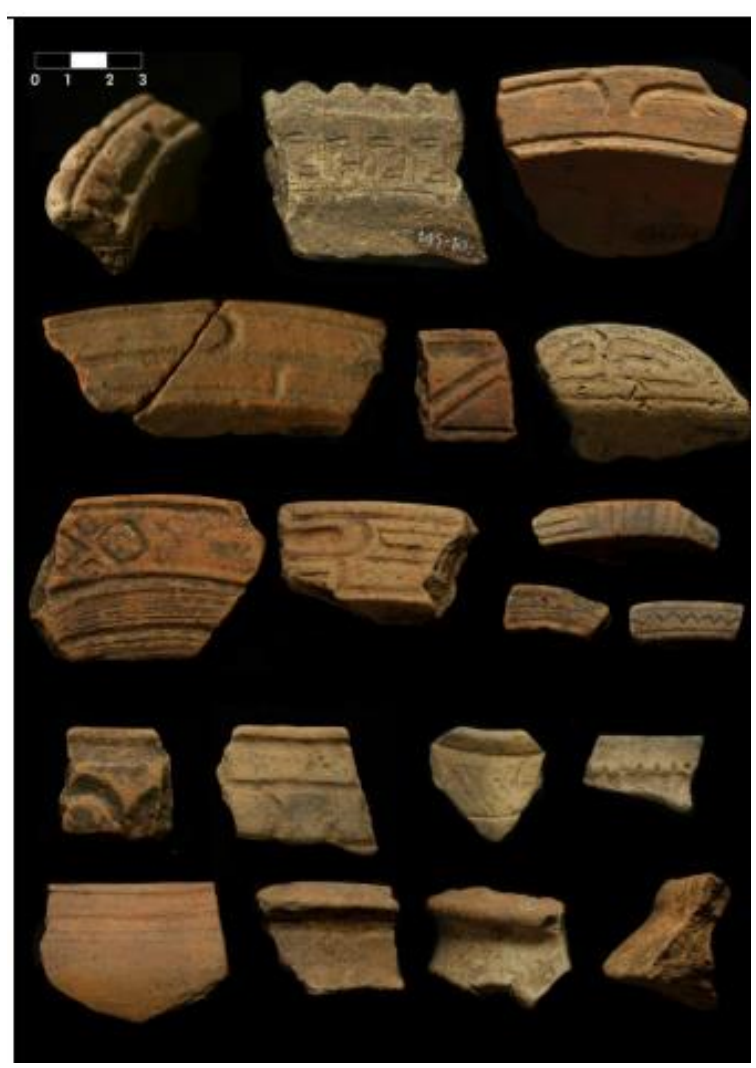

Figura 13: Fragmentos da Fase Caiambé no sítio Boa Esperança

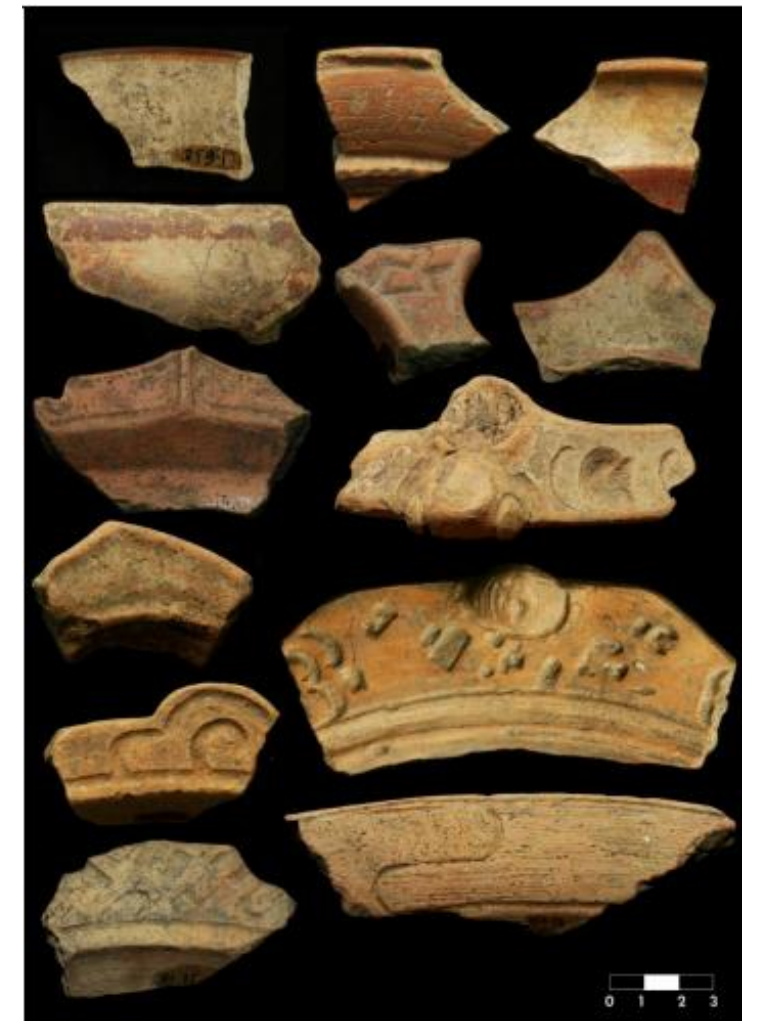

Figura 11: Fragmentos da Fase Pocó no sítio Boa Esperança

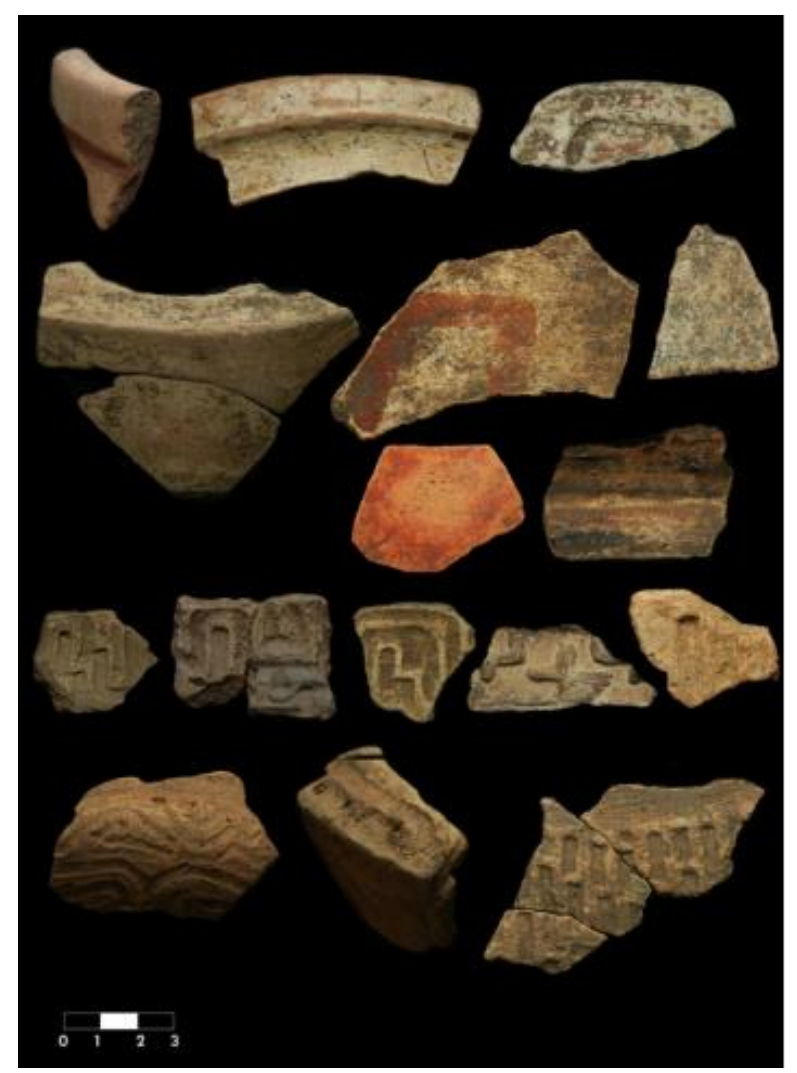

Figura 12: Fragmentos da fase Tefé no sítio Boa Esperança 
O material cerâmico associado à fase Caiambé da Tradição Borda Incisa em termos quantitativos tem ocorrência moderada, sendo de fato a fase Pocó aquela de maior densidade no sitio. Mas algumas características da fase Caiambé em Boa Esperança, destacam sua relativa padronização quando comparado ao material apresentado por Hilbert (1968). O cauixi é o antiplástico predominante, embora a ocorrência da mistura com o caraipé. A característica mais marcante é a presença de incisões duplas e paralelas em motivos geométricos e curvilíneos. Essas linhas duplas geralmente ocorrem na superfície externa dos vasilhames, mas também nas bordas, sendo as extrovertidas, formando flanges, suporte para a decoração. Os lábios serrilhados ocorrem moderadamente (Figura13). Um fragmento de cerâmica temperado com caraipé, com engobo branco e linhas incisas duplas foi datado em 1.080+-30 BP (890-1.020 A.D.). Essa data é mais recente do que aquelas obtidas por Hilbert na definição da fase. Para complexificar um pouco mais o quadro, a

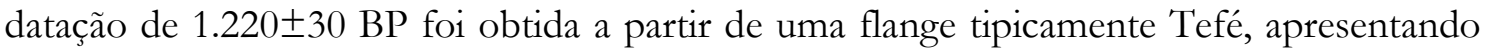
portanto uma antiguidade inesperada. Embora seja necessária cautela nas interpretações dessa data - considerada em conjunto com outras disponíveis para a Tradição Polícroma em afluentes do médio Solimões, a saber, 850 d.C (Tamanaha, 2012) 763 d.C (Hanke, 1959) e 770 d.C (Neves, 2010), tal como aquelas recentemente publicadas por Belleti (2015) - ela não é aberrante na cronologia, reforçando o argumento sobre a expansão policroma como uma processo complexo e não linear.

No Sítio Bom Jesus do Baré foram identificados contextos bastante distintos daqueles de Boa Esperança. São ausentes solos antrópicos e estratigrafia com camadas culturais, mas somente dois conjuntos de urnas cerâmicas. Costa em sua pesquisa, levantou discussões sobre a funcionalidade e hipóteses sobre fatores que contribuiriam para a inibição da formação da terra preta devido aos alagamentos sazonais. Nesse sítio, foi amostrada uma área de $4 \mathrm{~m}^{2}$, e coletadas 5 urnas, o tratamento em laboratório dos materiais aponta para uso funerário dos recipientes em dois casos, e em pelo menos um deles, o contexto registrado indica o sepultamento primário de um indivíduo (Costa et al, 2012; Rapp Py-Daniel, 2013). Até o inicio da nossa pesquisa, não havia datações absolutas relacionadas ao Bom Jesus, mas devido às características morfológicas e decorativas, o sítio foi vinculado à fase Caiambé da Tradição Borda Incisa.

4. As questões e objetivos da pesquisa

Como vimos, na Amazõnia Central a Tradição Borda Incisa apresenta uma cronologia que se estende pelo primeiro milênio d.C. com as contemporâneas fases 
Manacapuru e Paredão, que são tratadas com uma abordagem de longa duração iniciada com as cerâmicas da tradição Pocó-Açutuba. Neves e colaboradores (2014) ao definirem a Tradição Pocó-Açutuba, reforçam o argumento de um desenvolvimento lento e gradual das ocupações dessa tradição se diversificando em fases locais relacionadas a tradição Borda Incisa.

As fases Manacapuru e Açutuba são exemplo dessa dinâmica, devido semelhanças entre as tecnologias cerâmicas, mas essa continuidade expressa na cerâmica não é percebida no contexto de deposição do material já que na estratigrafia dos sítios as diferenças são marcadas havendo uma correlação entre fase Açutuba e pacotes de solos antrópicos anteriores a formação da terra preta. No entanto, esse padrão não é o mesmo no baixo Amazonas, onde as diferenças entre as fases Pocó e Konduri são claras em termos de datação e das características dos materiais, mas não o são em termos de estratigrafia, já que os dois componentes estão presentes em uma camada de terra preta contínua (Guapindaia, 2008). No Sítio Boa Esperança essas correlações entre presença de cerâmica Pocó na terra preta, solos anteriores a ela e nas feições são tênues, visto que a Tradição Pocó-Açutuba, ocorre em ambos os contextos.

Ainda, considerando a diversidade de composição e tamanho dos sítios às margens do lago Amanã, a amostragem realizada por Costa, de dois sítios com configurações distintas, embora pudesse indicar usos e funcionalidades diferentes desses epaços no passado, fatores ecológicos relacionados à dinâmica de alagação com o regime de enchente e vazante, foram mais preponderantes para explicar as diferenças entre Boa Esperança e Bom Jesus do Baré. Portanto essa pesquisa foi formulada contemplando dois aspectos:

i) Tendo em vista a cronologia do sítio Boa Esperança, na qual há uma variação entre variabilidade cerâmica e contexto de deposição, é latente a necessidade de testar se ela é consistente em outros sítios da região. A principal questão é compreender em que medida as mudanças e continuidades percebidas até o momento neste sítio, podem se relacionar às dinâmicas de ocupações da fase Caiambé da Tradição Borda Incisa, ainda pouco conhecida no quadro cronoestilístico regional. Lembrando que na Amazônia central, o período das ocupações dessa Tradição é interpretado como de adensamento populacional e onde as mudanças nas paisagens são mais intensas.

ii) A presença dos campos de urnas, como no caso do sítio Bom Jesus do Baré, é relevante na região de Amanã. A formação do registro nesses contextos pode estar relacionada às condições ecológicas, mas nos parece razoável considerar como preponderante uso diferenciado desses espaços, especificamente como cemitérios e não como locais de habitação. 
Indícios de um processo de intensificação das ocupações do lago Amanã estão impressos na formação dos pacotes de terra preta, datados em meados do primeiro milênio d.C. e a fase Caiambé até o momento foi encontrada em todos os sítios escavados no Lago Amanã. Considerando as informações disponíveis para a Amazônia central apresentados acima, hipoteticamente, é neste período que aldeias contemporâneas em diferentes pontos do Lago começam a se estabelecer, com a formação de espaços específicos nas próprias aldeias e próximos a elas, reservados para a deposição de grandes urnas cerâmicas funerárias e rituais. Esses sítios-cemitérios podem ser entendidos como a constituição física de paisagens simbólicas, que fariam parte da construção de um território, sinais de uma regionalidade - um aspecto cultural bastante caro às ocupações de matriz Arawak.

Em suma, o objetivo da pesquisa foi compreender os significados da fase Caiambé de modo a elucidar se as ocupações seriam resultado de um desenvolvimento local, cujo estilo seria correlacionado às cerâmicas mais antigas encontradas na região; ou de outra forma, se esta fase representaria um episódio distinto de ocupação no lago sem relação necessária com as ocupações anteriores. O refinamento da caracterização dos contextos e das próprias cerâmicas foi a principal questão da pesquisa, de modo relacioná-la às dinâmicas sócio-culturais da tradição Borda Incisa, e evidenciar se há ou não relações de continuidade, mudança ou ruptura entre as diferentes fases identificadas.

Entre os objetivos específicos estão:

- Caracterizar os contextos da fase Caiambé;

- Identificar a variabilidade crono-tipológica do material cerâmico.

- Produzir um perfil detalhado dos aspectos tecnológicos visando o reconhecimento de estilos particulares e sua transformação ao longo da sequencia estratigráfica.

- Realizar estudo comparativo entre as cerâmicas da Tradição Borda Incisa da área de estudo e aquelas de outros sítios na Amazônia Central, de forma mais específica, com cerâmicas da fase Manacapuru;

- Evidenciar relações entre as ocupações Caiambé e o contexto Pocó/Açutuba identificado no Lago Amanã.

- Subsidiar o plano de gestão da RDS Amanã 


\section{CAPÍTULO 3}

\section{OS SíTIOS ARQUEOLÓGICOS DA RDS AMANÃ: INTERVENÇÕES E OS CONTEXTOS IDENTIFICADOS}

\section{Os sítios arqueológicos da RDS Amanã}

Um levantamento não -interventivo durante os anos de 2006 e 2008 realizado por Bernardo Costa, de carater oportunístico e baseado nas informações locais sobre o conhecimento de ocorrência de fragmentos cerâmicos (cacos de índio) registrou a existência de 32 sítios arqueológicos (Costa, 2008). Durante este levantamento foi percorrido quatro setores da RDS Amanã, os setores Amanã 1 e 2 que compreende todo o lago homônimo, o setor São José, que compreende o lago Urini e o paranã Castanho.

Foi dada prioridade para os locais marcados pela ocupação humana, sendo verificadas as seguintes áreas: comunidades, moradias isoladas, roçado, pasto, pontas de terra firme, acampamento de pesca, caça e coleta. Os sítios foram classificados entre aqueles com centenas ou milhares de fragmentos de cerâmica, a área foi estimada calculando-se a dispersão dos fragmentos de cerâmica na superfície do solo e com auxilio de um GPS foram coletados os pontos UTM com Datum SAD 69. Todas as urnas ${ }^{18}$ identificadas também foram contabilizadas e fichas específicas do Cadastro Nacional de Sítios Arqueológicos (CSNA) do IPHAN foram preenchidas.

Pensando no desenvolvimento de atividades futuras foi adotado o conceito de processos pós-deposicionais. A partir da observação dos processos naturais(erosão pluvial, inundações sazonais) e culturais (habitação, criação de animais, construção de moradias e outras intervenções no terreno) atuando na formação de cada sítio, aliados às informações do tamanho e composição do sítios foram atribuídos maior ou menor relevância a eles, e nesse sentido, os sítios em áreas de comunidade foram considerados prioritários. Esta lista de relevância foi amplamente publicada (Costa, 2008; 2012) e vem orientando as intervenções arqueológicas para mapeamento e coleta de amostras.

No ano de 2011 durante uma expedição do IDSM para coleta de informações do Censo Demográfico e Levantamento Socioeconômico em todos os setores políticos da

\footnotetext{
${ }^{18} \mathrm{O}$ termo urna foi utilizado para os potes inteiros ou aparentemente inteiros, onde era possível observar o contorno da borda aflorando na superfície do terreno.
} 
RDS Amanã, foram identificados de modo oportunístico e seguindo metodologia semelhante, nove sítios arqueológicos em comunidades. Els estão localizados às margens dos principais paranãs utilizados na RDS Amanã e na margem esquerda do Rio Japurá até o limite da Reserva, já próximo à cidade de Maraã. Na tabela 6 estão sistematizadas algumas informações de georeferenciamento, composição e observações gerais sobre esses sítios.

\begin{tabular}{|c|c|c|}
\hline $\begin{array}{l}\text { Sítio } \\
\text { (UTM) }\end{array}$ & Composição & Observações \\
\hline $\begin{array}{l}\text { Nova Olinda } \\
310731 / 9686916\end{array}$ & $\begin{array}{l}\text { Terra Preta } \\
\text { arqueológica; } \\
\text { Fragmentos } \\
\text { cerâmicos; } \\
\text { Urnas }\end{array}$ & $\begin{array}{l}\text { Sítio cerâmico a céu aberto em área de comunidade localizada } \\
\text { no Paranã Pirataíma. Na área de circulação da comunidade } \\
\text { não são encontrados fragmentos apenas no terreno atrás da } \\
\text { linha de casas. Segundo informações orais existe terra preta }\end{array}$ \\
\hline $\begin{array}{l}\text { Paraíso } \\
352010 / 9662796\end{array}$ & $\begin{array}{l}\text { Fragmentos } \\
\text { cerâmicos; } \\
\text { Urnas }\end{array}$ & $\begin{array}{l}\text { Sítio cerâmico a céu aberto em área de comunidade localizada } \\
\text { no Paranã Tambaqui. } \\
\text { Na área de circulação da comunidade são encontrados poucos } \\
\text { fragmentos cerâmicos. }\end{array}$ \\
\hline $\begin{array}{l}\text { Edson } \\
304448 / 9700545\end{array}$ & $\begin{array}{l}\text { Fragmentos } \\
\text { cerâmicos; } \\
\text { Urnas; } \\
\text { Terra preta }\end{array}$ & $\begin{array}{l}\text { Local de moradia do Sr Edson, entre as comunidades São } \\
\text { José e Samaria, no Paranã Tambaqui. Moradores informam } \\
\text { sobre existência de terra preta e relatos sobre urnas expostas } \\
\text { no barranco por eventos de terra caída }\end{array}$ \\
\hline $\begin{array}{l}\text { São João do } \\
\text { Ipecaçu } \\
298231 / 9704254\end{array}$ & $\begin{array}{l}\text { Fragmentos } \\
\text { cerâmicos; } \\
\text { Urnas; } \\
\text { Terra preta; } \\
\text { Lítico polido }\end{array}$ & $\begin{array}{l}\text { Sítio cerâmico a céu aberto de grandes proporções formado } \\
\text { por concentrações de fragmentos cerâmicos e urnas funerárias } \\
\text { aflorando a superfície. Existência de manchas de terra preta } \\
\text { também visíveis na superfície. }\end{array}$ \\
\hline $\begin{array}{l}\text { Matusalém } \\
\text { 296458/9706198 }\end{array}$ & $\begin{array}{l}\text { Fragmentos } \\
\text { cerâmicos; }\end{array}$ & $\begin{array}{l}\text { Sítio cerâmico a céu aberto localizado às margens do Lago } \\
\text { Ipecaçu na comunidade Matusalém. Pequenas concentrações } \\
\text { cerâmicas foram observadas. Informações orais indicam } \\
\text { formas de vasos cerâmicos o que pode indicar um grau } \\
\text { elevado de preservação do sítio. }\end{array}$ \\
\hline $\begin{array}{l}\text { Porto Alves } \\
255533 / 9773721\end{array}$ & $\begin{array}{l}\text { Fragmentos } \\
\text { cerâmicos, } \\
\text { Urnas; } \\
\text { Terra preta }\end{array}$ & $\begin{array}{l}\text { Sítio cerâmico a céu aberto situado na margem esquerda do } \\
\text { Rio Japurá. Formado por manchas de terra preta, grandes } \\
\text { concentrações de fragmentos cerâmicos e urnas }\end{array}$ \\
\hline $\begin{array}{l}\text { Curupira } \\
255302 / 9774601\end{array}$ & $\begin{array}{l}\text { Fragmentos } \\
\text { cerâmicos; } \\
\text { Terra preta }\end{array}$ & $\begin{array}{l}\text { Sítio cerâmico a céu aberto localizado na mergem esquerda do } \\
\text { Lago Curupira. A dispersão dos vestígios cerâmicos } \\
\text { concentra-se na porção oeste da comunidade atual. } \\
\text { Informações orais destacam existência de terra preta. }\end{array}$ \\
\hline $\begin{array}{l}\text { Nova Jacitara } \\
252623 / 977696\end{array}$ & $\begin{array}{l}\text { Fragmentos } \\
\text { cerâmicos; } \\
\text { Urnas }\end{array}$ & $\begin{array}{l}\text { Sítio cerâmico a céu aberto na margem esquerda do Rio } \\
\text { Japurá, por toda extensão da comunidade atual são } \\
\text { encontrados fragmentos cerâmicos, mas com áreas de maior } \\
\text { densidade. Informações orais dos moradores destacam } \\
\text { existência de urnas funerárias. }\end{array}$ \\
\hline $\begin{array}{l}\text { São Pedro do } \\
\text { Jacitara } \\
252127 / 9778163\end{array}$ & $\begin{array}{l}\text { Fragmentos } \\
\text { cerâmicos, } \\
\text { Urnas; } \\
\text { Terra preta }\end{array}$ & $\begin{array}{l}\text { Sítio cerâmico a céu aberto localizado na margem esquerda do } \\
\text { Rio Japurá. Sua área compreende a comunidade atual, cujo } \\
\text { terreno oscila entre baixadas e elevações. Formado por } \\
\text { machas de terra preta, concentrações cerâmicas e urnas. }\end{array}$ \\
\hline
\end{tabular}

Tabela 6: Relação de sítios arqueológicos registrados e cadastrados no CNSA 
Também foram coletadas informações orais sobre o aparecimento de fragmentos e urnas cerâmicas em outros 15 locais próximos às comunidades e áreas de uso, que estão listadas na tabela 7. Embora não tenha sido possível percorrer todos os locais mencionados pelos moradores e registrá-los após vistoria técnica, há informações preliminares sobre o potencial arqueológico dos outros setores políticos da RDS, sendo necessária a continuidade do levantamento, seguindo a mesma metodologia aplicada anteriormente, para a avaliação da composição, tamanho e inclusão desses sítios na lista de relevância para intervenções futuras.

\begin{tabular}{|c|c|c|c|}
\hline Nome Sítio & Localização & Vestígios & Informante e Observações Gerais \\
\hline $\begin{array}{l}\text { Ponta } \\
\text { repartimento }\end{array}$ & $\begin{array}{l}\text { Paranã } \\
\text { Coraci - } \\
\text { margem } \\
\text { direita }\end{array}$ & $\begin{array}{l}\text { fragmentos; } \\
\text { terra preta }\end{array}$ & $\begin{array}{l}\text { Francione (Filho do Sr Wilson, morador do } \\
\text { Repartimento). Local em frente À comunidade } \\
\text { São Sebastião do Repartimento }\end{array}$ \\
\hline $\begin{array}{l}\text { Taboca do } \\
\text { Urini }\end{array}$ & $\begin{array}{l}\text { Lago Urini- } \\
\text { margem } \\
\text { esquerda }\end{array}$ & $\begin{array}{l}\text { Terra Preta; } \\
\text { fragmentos; } \\
\text { Urnas }\end{array}$ & $\begin{array}{l}\text { Segundo Sr Pedro Brasil (morador de São José } \\
\text { do Urini) neste local há muitos cacos na } \\
\text { mesma quantidade que na comunidade São } \\
\text { José do Urini. }\end{array}$ \\
\hline $\begin{array}{l}\text { Bacaba do } \\
\text { Urini }\end{array}$ & $\begin{array}{l}\text { Lago Urini- } \\
\text { margem } \\
\text { esquerda }\end{array}$ & fragmentos & $\begin{array}{l}\text { Sr Pedro Brasil. Parece ser um sítio menor, de } \\
\text { baixa densidade cerâmica. }\end{array}$ \\
\hline Bom Jardim & Lago Preto & $\begin{array}{l}\text { terra preta; } \\
\text { fragmentos; } \\
\text { urnas }\end{array}$ & $\begin{array}{l}\text { Sr Assis (Morador de Bom Jesus do Lago } \\
\text { Preto). Local de roça da família na cabeceira do } \\
\text { Lago Preto, por todo canal na seca há muitos } \\
\text { fragmentos, já encontraram potes inteiros } \\
\text { "bordados" durante a seca. }\end{array}$ \\
\hline Bananal & $\begin{array}{l}\text { Paranã } \\
\text { Tambaqui }\end{array}$ & Fragmentos & $\begin{array}{l}\text { Sr Geraldo. Local de roça da família. } \\
\text { Informação coletada pela Equipe do Censo }\end{array}$ \\
\hline $\begin{array}{l}\text { Lago } \\
\text { Teodoro }\end{array}$ & $\begin{array}{l}\text { Paranã } \\
\text { Cubuá }\end{array}$ & $\begin{array}{l}\text { Fragmentos; } \\
\text { urnas; } \\
\text { terra preta }\end{array}$ & $\begin{array}{l}\text { Sr João Praia. Local de roça da familia no } \\
\text { Paranã Tambaqui. Disse já ter encontrado } \\
\text { garrafas. }\end{array}$ \\
\hline $\begin{array}{l}\text { Roçado Sr. } \\
\text { Néia }\end{array}$ & $\begin{array}{l}\text { São João do } \\
\text { Ipecaçu }\end{array}$ & $\begin{array}{l}\text { Fragmentos } \\
\text { Urnas; } \\
\text { Terra preta; } \\
\text { Lítico polído }\end{array}$ & $\begin{array}{l}\text { Sr Raiumundo e Sr Neia (Moradores de São } \\
\text { João do Ipecaçu). Local de roça da familia }\end{array}$ \\
\hline $\begin{array}{l}\text { Boa fé do } \\
\text { Joacaca - }\end{array}$ & Rio Japurá & $\begin{array}{l}\text { Fragmentos; } \\
\text { Lítico polido } \\
\text { Garrafas } \\
\text { (vidro?) }\end{array}$ & $\begin{array}{l}\text { Sr Negão (Sebastião Ferrão) e Sra Nilze. } \\
\text { Casal fundador da comunidade, relataram que } \\
\text { na comunidade em si não há fragmentos, mas } \\
\text { nas roças no entorno sim, com incidência de } \\
\text { pedras de raio (machados polidos). }\end{array}$ \\
\hline Paraíso & Rio Japurá & $\begin{array}{l}\text { muitos } \\
\text { fragmentos }\end{array}$ & $\begin{array}{l}\text { Sr Jociro e Sr Raimunda (Moradores de } \\
\text { Paraiso). Relatam que não há vestígios na } \\
\text { comunidade, mas no igarapé de acesso ao } \\
\text { cemitério da comunidade. }\end{array}$ \\
\hline
\end{tabular}




\begin{tabular}{lll}
\hline Curupira II & Japurá - & Fragmentos \\
& Lago & urna \\
& Curupira & antropomorfa
\end{tabular}

A senhora Otelina tem 76 anos e atualmente mora na comunidade Porto Alegre. Segundo ela aos 13 anos de idade quando trabalhava na roça da família com a irmã, encontraram um pote grande que tinha olhos, nariz, sobrancelhas e boca. O vaso estava tampado, mas com a ajuda da mãe abriram o vaso e encontraram ossos até o pescoço. Essa antiga roça estava localizada na margem oposta a comunidade atual Curupira.

\begin{tabular}{|c|c|c|c|}
\hline $\begin{array}{l}\text { Ilha Porto } \\
\text { Alves }\end{array}$ & Japurá & fragmentos & $\begin{array}{l}\text { Loira e irmãos, relataram aparecimento de } \\
\text { cacos na época da seca }\end{array}$ \\
\hline $\begin{array}{l}\text { Praia da } \\
\text { Ponta }\end{array}$ & Japurá & Fragmentos & $\begin{array}{l}\text { Sr Maria Adélia. Afirmou que na seca } \\
\text { aparecem muitos cacos na praia que se forma } \\
\text { próximo à comunidade }\end{array}$ \\
\hline $\begin{array}{l}\text { Centro } \\
\text { grande }\end{array}$ & $\begin{array}{l}\text { Centro } \\
\text { Grande }\end{array}$ & & $\begin{array}{l}\text { Sr Pedro e Sr. Julio. Local que dizem aparecer } \\
\text { muitos cacos mas não informaram um local } \\
\text { específico, se referiram ao caminho paras os } \\
\text { castanhais. }\end{array}$ \\
\hline Cupim & $\begin{array}{l}\text { Centro } \\
\text { grande }\end{array}$ & $\begin{array}{l}\text { fragmentos e } \\
\text { urnas }\end{array}$ & $\begin{array}{l}\text { Sr Julio. Antiga colocação chamada cupim na } \\
\text { área de terra firme do Centro Grande. }\end{array}$ \\
\hline $\begin{array}{l}\text { Igarapé } \\
\text { Branco }\end{array}$ & $\begin{array}{l}\text { Centro } \\
\text { grande }\end{array}$ & $\begin{array}{l}\text { terra preta; } \\
\text { fragmentos; } \\
\text { urnas }\end{array}$ & $\begin{array}{l}\text { Local de nascimento do Sr Julio, que informou } \\
\text { sobre a densidade do material, que segundo } \\
\text { ele, seria semelhante a quantidade de vestígios } \\
\text { do Sítio São José do Urini. }\end{array}$ \\
\hline
\end{tabular}

Tabela 7: Sítios informados pelos moradores próximos às comunidades e áreas de uso.
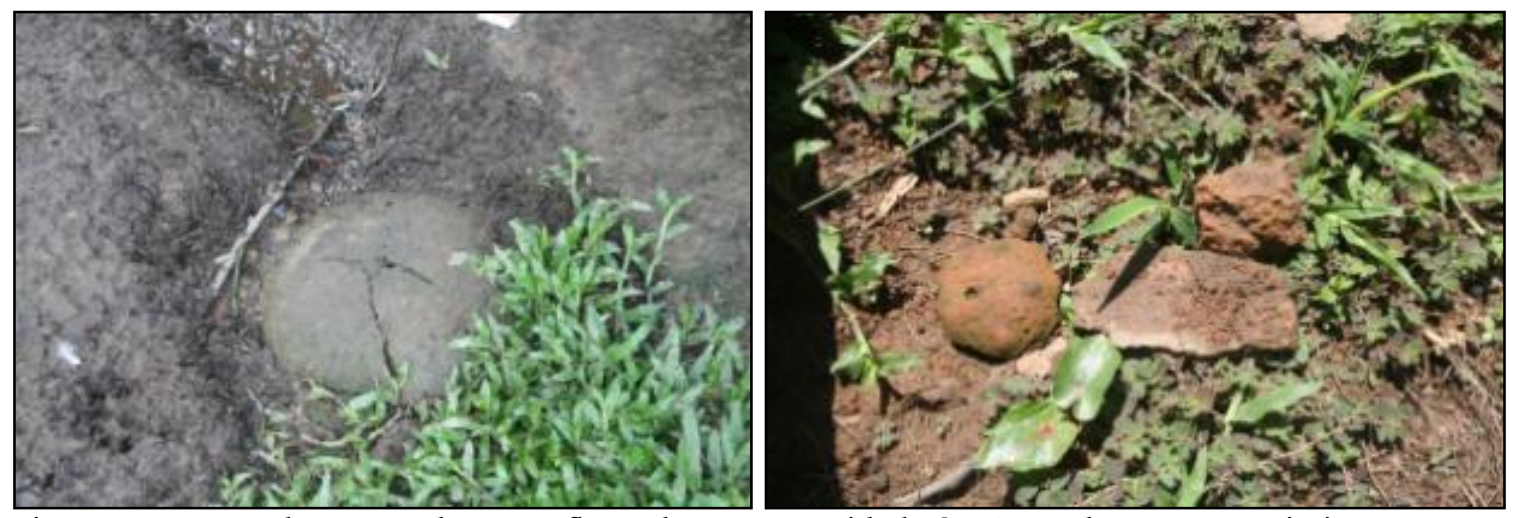

Figura 14: Esquerda: tampa de urna aflorando na comunidade São João do Ipecaçu. Direita: Fragmentos na superfície do terreno na comunidade Curupira, Lago Curupira, Rio Japurá.
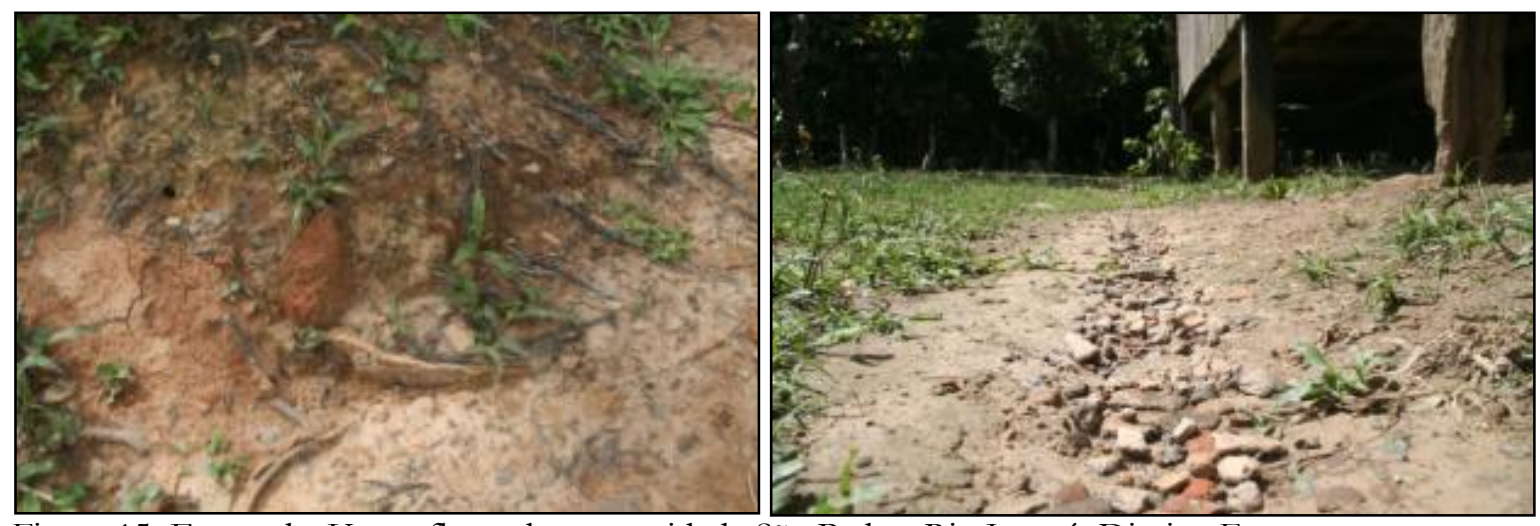

Figura 15: Esquerda: Urna aflorando comunidade São Pedro, Rio Japurá. Direita: Fragmentos na superfície próximo às casas na Comunidade Porto Alves, Rio Japurá. 


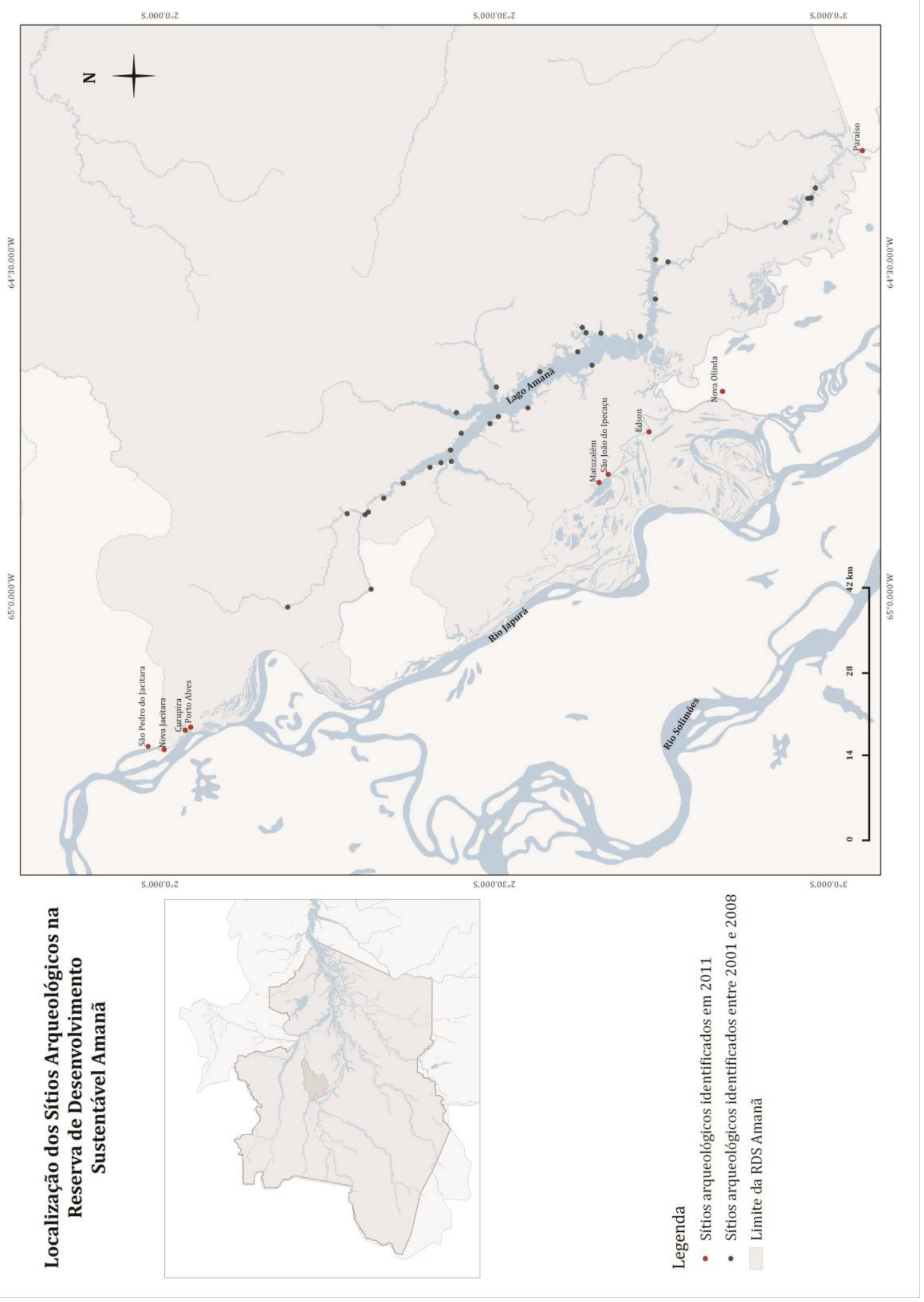

Mapa 4: Localização dos 41 sítios identificados na RDS Amanã 
2. Metodologia de intervenção: mapeamento digital e escavação

A metodologia usada nas intervenções é semelhante àquela do Projeto Amazônia Central que já foi amplamente exposta em publicações anteriores (Castro, 2009; Costa, 2011; Lima, 2008; Machado, 2005; Moraes, 2006; Neves 2010, 2000, Neves et al., 2003b)

O mapeamento consistiu na elaboração de uma planta topográfica com auxílio de estação total, onde são inseridas as informações da paisagem atual (como domicílios, casas de farinha, espaços comunitários, escola, posto de saúde, trilhas, caminhos, plantações, campos de futebol, margem do lago e nível da água) bem como informações da localização e densidade dos vestígios arqueológicos. Para o cálculo da área de dispersão dos vestígios e da profundidade do pacote arqueológico foram realizadas tradagens - intervenções de subsuperfície de aproximadamente $30 \mathrm{~cm}$ com 1 metro de profundidade dispostas em linhas arbitrárias (paralelas e perpendiculares), com $25 \mathrm{~m}$ de distância entre si. Foram quantificados e coletados os fragmentos cerâmicos e observadas a textura e coloração do solo com o uso da carta 'Munsell Soil Color Charts'.

A malha de tradagens obedece um quadriculamento do sítio, composto por unidades de $1 \mathrm{~m}^{2}$, essas quadrículas são denominadas de acordo com um sistema de coordenadas cartesianas orientadas a partir de um ponto zero arbitrário. Nesse sistema, a identificação de uma quadrícula é dada pela sua distância com relação a este zero (Neves, 2013).

As etapas de escavação ocorreram na sequência das etapas de mapeamento e delimitação, geralmente com a mesma equipe que trabalhou em cada sítio. Os critérios levados em conta na escolha dos locais para a abertura de unidades-teste foram: ponto com maior quantidade de fragmentos de cerâmica identificados e coletados das tradagens; a presença de terra preta e locais que apresentaram urnas em maior risco de destruição - estes últimos normalmente são demandas apresentadas pelos moradores.

As unidades de escavação, são 'unidades teste' com $1 \mathrm{~m}^{2}$ cada, nomeada levando-se em conta a posição do quadrante SW das mesmas dentro do grid elaborado durante o mapeamento digital. Em todas as unidades escavadas foram aplicados os mesmos métodos e materiais. Foram escavadas em níveis arbitrários e artificiais de $10 \mathrm{~cm}$ com o seguinte procedimento: todo solo é escavado com colheres apropriadas e peneirado em uma malha de $0,5 \mathrm{~cm}$. Todos os fragmentos de cerâmica, carvões, restos faunísticos e vestígios líticos são coletados separadamente em embalagens plásticas apropriadas e identificadas. Cada conjunto de vestígios recebe um número de proveniência $(\mathrm{PN})$ que os associa 
espacialmente ao sítio. É realizado o registro das informações mais relevantes em fichas especificas de níveis de escavação. Nessas fichas são tecidas observações a respeito da localização, nível estratigráfico, cor e textura do solo, tipo de vestígio e desenhos esquemáticos (croquis) das principais ocorrências. Artefatos, fragmentos diagnósticos e carvões, quando bem preservados e associados à contextos mais controlados, são coletados e registrados individualmente (coordenadas x, y e z). Após a escavação, coleta de amostras e registro através de desenhos técnicos e fotografias dos perfis estratigráficos realiza-se o fechamento da unidade com o próprio solo escavado.

\section{Os sítios estudados}

Até o momento seis sítios sofreram intervenções e representam uma amostra das porções superiores e inferiores do lago Amanã, a escolha deles se deu em função da relevância dos sítios formulada a partir dos levantamentos não-interventivos (Costa, 2008). Os sítios Bom Jesus do Baré e Boa Esperança já tiveram seus contextos analisados em publicações anteriores e sucintamente apresentados no capítulo 2. O primeiro foi objeto de estudos de arqueologia funerária e relacionado ao contexto da fase Caiambé (Costa et al, 2012; Costa, 2012), ainda sim, resolvemos retomar as discussões sobre ele no capítulo 5, reservado às urnas funeárias. Já Boa Esperança, ofereceu uma cronologia preliminar para o lago Amanã (Gomes, 2011; Costa 2012) e a partir dele, as questões e hipóteses do presente trabalho foram formuladas.

A seguir, apresento quatro sítios que tem seus contextos mapeados e conhecidos. Cacoal do Amanã e São Miguel do Cacau, são sítios cerâmicos a céu aberto, formados por camadas de terra preta e grande variabilidade artefatual. São interpretados como sítios de habitação e ambos apresentam áreas específicas, reservadas para a deposição de urnas cerâmicas. Os sítios Kalafate e Monte Sinai são sítios de pequenas proporções que não apresentam camadas de terra preta, constituídos basicamente por conjuntos de urnas depositadas no solo de matriz argilosa, o que vem sendo interpretado como a constituição de espaços de uso diferenciado, exclusivos para enterramentos. 


\subsection{Kalafate}

Sítio cerâmico a céu aberto identificado em 2006, localizado na porção inferior do lago Amanã. A etapa de mapeamento ocorreu em julho de 2011, com a participação de dois moradores. A quantidade de urnas diminuiu deste o inicio dos trabalhos de levantamento arqueológico em 2006, os fragmentos observados estão associados às urnas que se concentram na frente da linha de casas próximo à margem do lago. Foram realizadas 12 tradagens e somente uma apresentou vestígio arqueológico com apenas um fragmento de cerâmica.

O sítio se restringe à presença de urnas em uma área de 0,22 hectares, a ausência de terra preta e de fragmentos cerâmicos em subsuperfície que não associados aos grandes vasilhames. Por não apresentar nenhuma estratigrafia e por sua composição, é possível que o local tenha sido utilizado somente para o enterramento das urnas demonstrando um contexto semelhante ao identificado no Sítio Bom Jesus do Baré. Este sítio não passou por nenhuma etapa de escavação para coleta de amostras.

Quando identificado foram contabilizadas 30 urnas aflorando na superfície, durante seu mapeamento cinco anos depois, foram visualizadas 9 urnas. Nas observações de monitoramento foram identificadas 21 urnas dispostas ao longo da linha de casas e apenas uma não é visível durante o período das cheias (Furquim, 2014). Como é possível observar na Figura 16, a área onde está concentrado o conjunto de recipientes não sofre inundações, mesmo em episódios de cheias extremas como no ano de 2012. Portanto, diferente da inundação sazonal que ocorre no Sítio Bom Jesus do Baré, elemento considerado para uma possível inibição da formação de terra preta (Costa et al, 2012), as informações sugerem que a configuração do Sítio Calafate parece ser decorrente de uma área de uso diferenciada. 


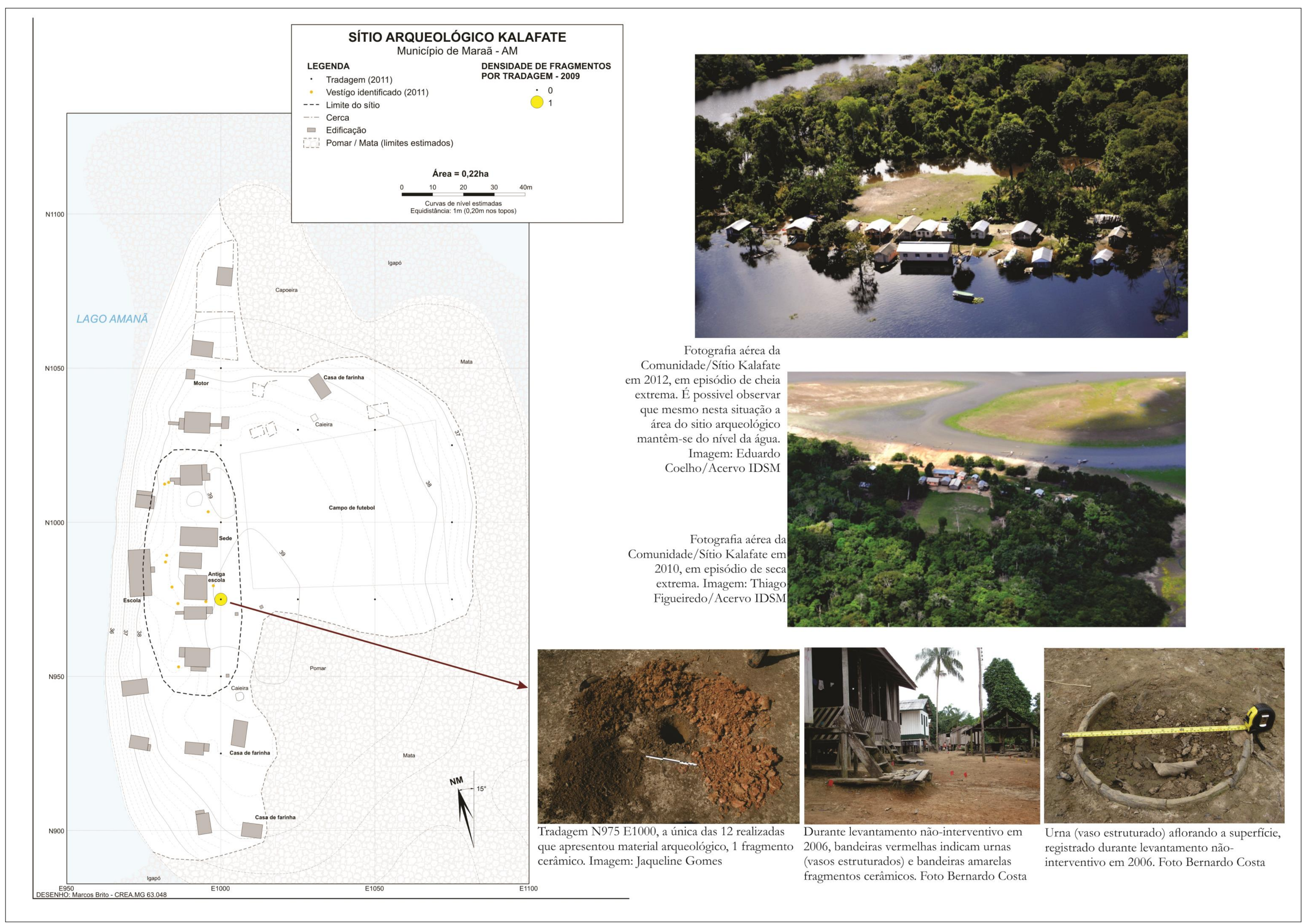

Figura 16: Prancha com planta topográfica do Sítio/Comunidade Kalafate e fotografias. 


\subsection{Monte Sinai}

Sítio cerâmico a céu aberto localizado na região de desembocadura do lago Amanã e identificado em 2006. Naquela ocasião foram observados centenas de fragmentos de cerâmica, contabilizadas 22 urnas aflorando a superfície e estimada uma área de $2.900 \mathrm{~m}^{2}$. Atualmente a comunidade possui apenas uma família que mantém uma criação de gado e roças na área. Já não é possível observar em superfície muitos fragmentos cerâmicos, bem como urnas - muitas já deterioradas ou cobertas pelo gramado, que é uma escolha recente da família.

O mapeamento foi realizado em julho de 2011, quando foram realizadas 34 tradagens e apenas 17 apresentaram fragmentos cerâmicos de pequenas proporções. Não foi observada a presença de terra preta arqueológica, mas um solo bruno em algumas áreas pontuais. Próximo à margem do igarapé, seguindo a linha de casas, 22 urnas foram registradas. O pacote arqueológico se restringe a uma faixa que se inicia na margem do igarapé e se estende por 60 metros, onde há um canal de aproximadamente $3 \mathrm{~m}$ de profundidade, que é responsável por isolar a área da porção de terra firme durante os períodos de cheia. A área total do sítio foi calculada em 2,18 hectares. O sítio não passou por etapa de escavação, seu mapa e fotografias podem ser visualizados na figura 17.

\subsection{Cacoal do Amanã}

Cacoal do Amanã é um sítio cerâmico a céu aberto, localizado na porção superior do lago Amanã, na sua margem direita e $3 \mathrm{~km}$ ao sul da comunidade Boa Esperança. Foi identificado em 2008, quando foram contabilizadas 47 urnas aflorando na superfície do terreno, sempre próximo à margem do lago (Figura 18). É um terreno de terra firme que sofre pouco com as alagações (Figura 19) e é utilizado atualmente para a criação de animais de grande porta, apresentando um pasto, pomar e áreas de capoeira. No ano de 2009 foi realizado o mapeamento digital da área de ocorrência dos vestígios arqueológicos, com a abertura de 38 linhas e 79 tradagens. A área total do sítio foi calculada em 5,8 hectares, apresentando um formato elipsoide (Figura 20). Grande parte da terra preta e cerâmica se encontra em uma faixa localizada a $150 \mathrm{~m}$ do curso d'água (Costa, 2011). Quando o sítio foi identificado em 2008, $\mathrm{Na}$ ocasião do mapeamento, apenas seis urnas foram visualizadas, concentradas na porção NW do sítio. 


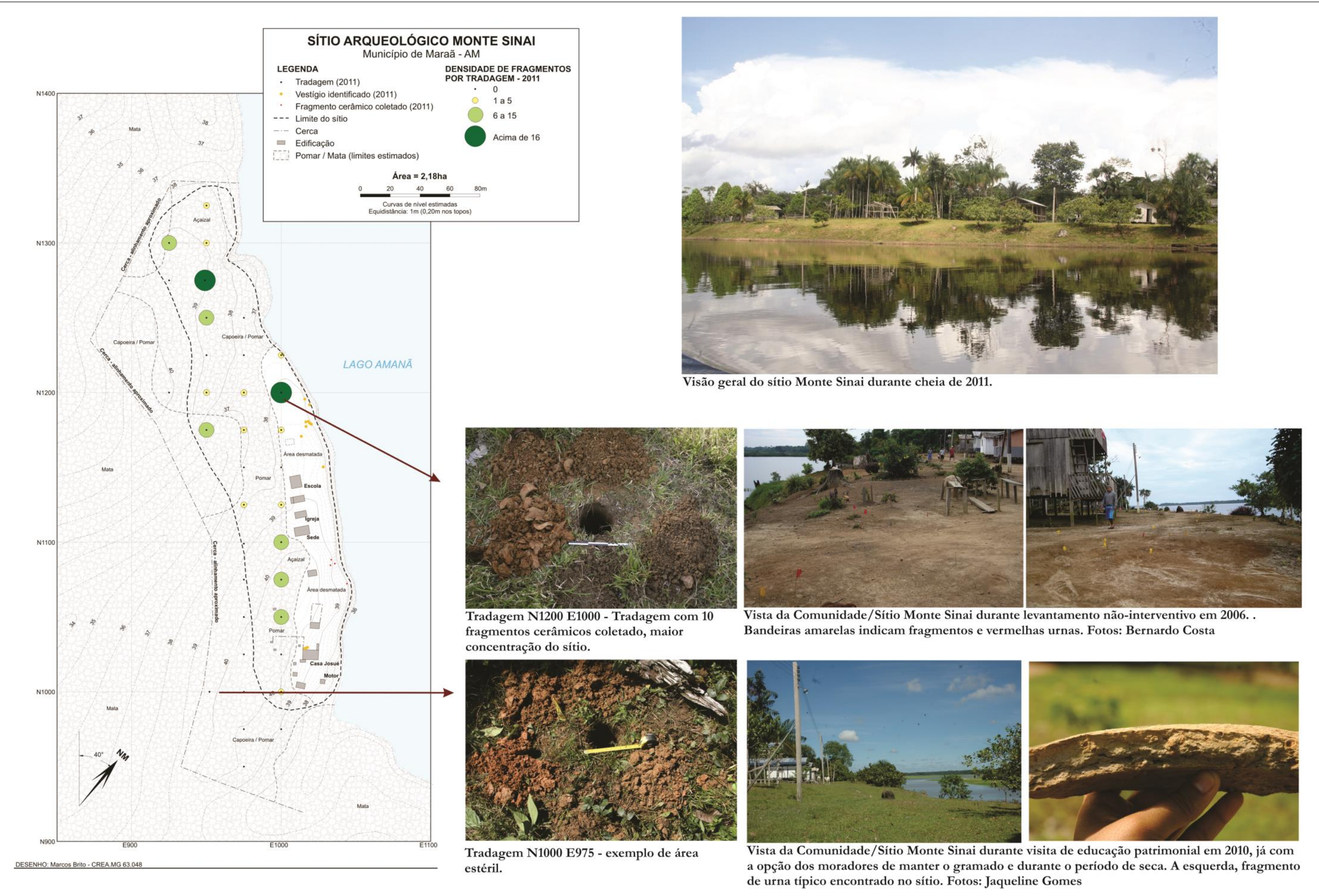

Figura 17: Prancha com fotografias e planta topográfica do sítio/comunidade Monte Sinai 


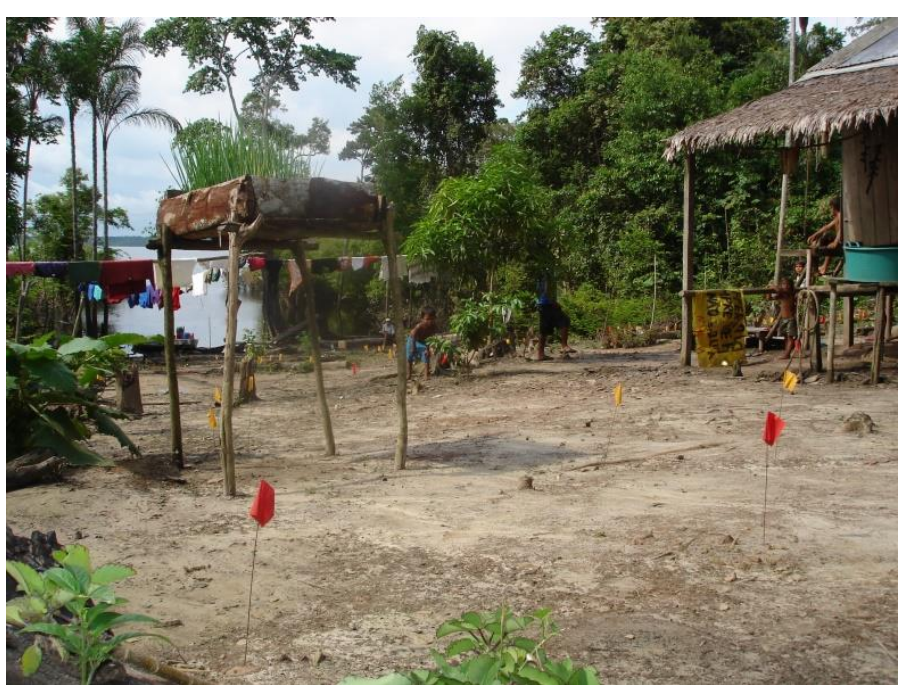

Figura 18: Levantamento não-interventivo no sítio Cacoal. Bandeiras amarelas indicam urnas e vermelhas fragmentos cerâmicos.
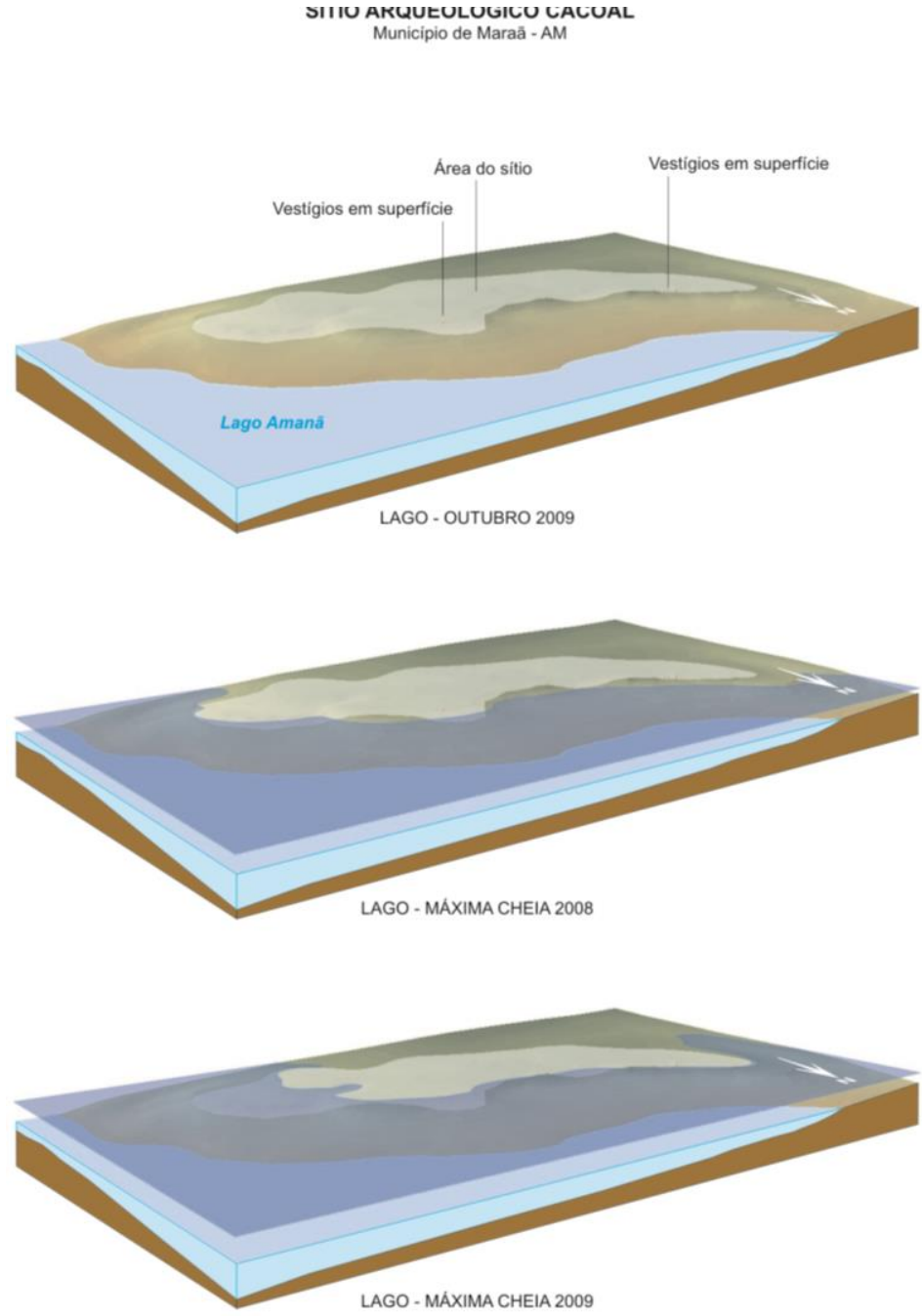

Figura 19: Ilustração dos diferentes níveis da água em diferentes momentos do ano.
Durante o monitoramento realizado no ano de 2013, esta área que é sazonalmente inundada, foi a que apresentou a maior concentração de urnas, que no sítio inteiro somou o número de 22. Informações de campo destacam que apenas uma urna é visível durante o período de cheia, estando o restante das urnas completamente submersas (Furquim, 2014).

A partir do mapeamento pode-se observar que há pelo menos dois padrões de distribuição e densidade de cerâmicas considerando a profundidade do pacote arqueológico. Como é possível observar na sequência de níveis artificiais na figura 21, a maior densidade do pacote se concentra até os $40 \mathrm{~cm}$ de profundidade em uma distribuição espacial que se mantem homogênea por 400 metros na orientação E/W. A partir dos $40 \mathrm{~cm}$ há uma grande queda na quantidade total de material cerâmico, se restringindo a uma área de aproximadamente 150 metros. Já aos $80 \mathrm{~cm}$ de profundidade o sítio é praticamente estéril, apenas na porção NW uma tradagem apresentou material arqueológico. 


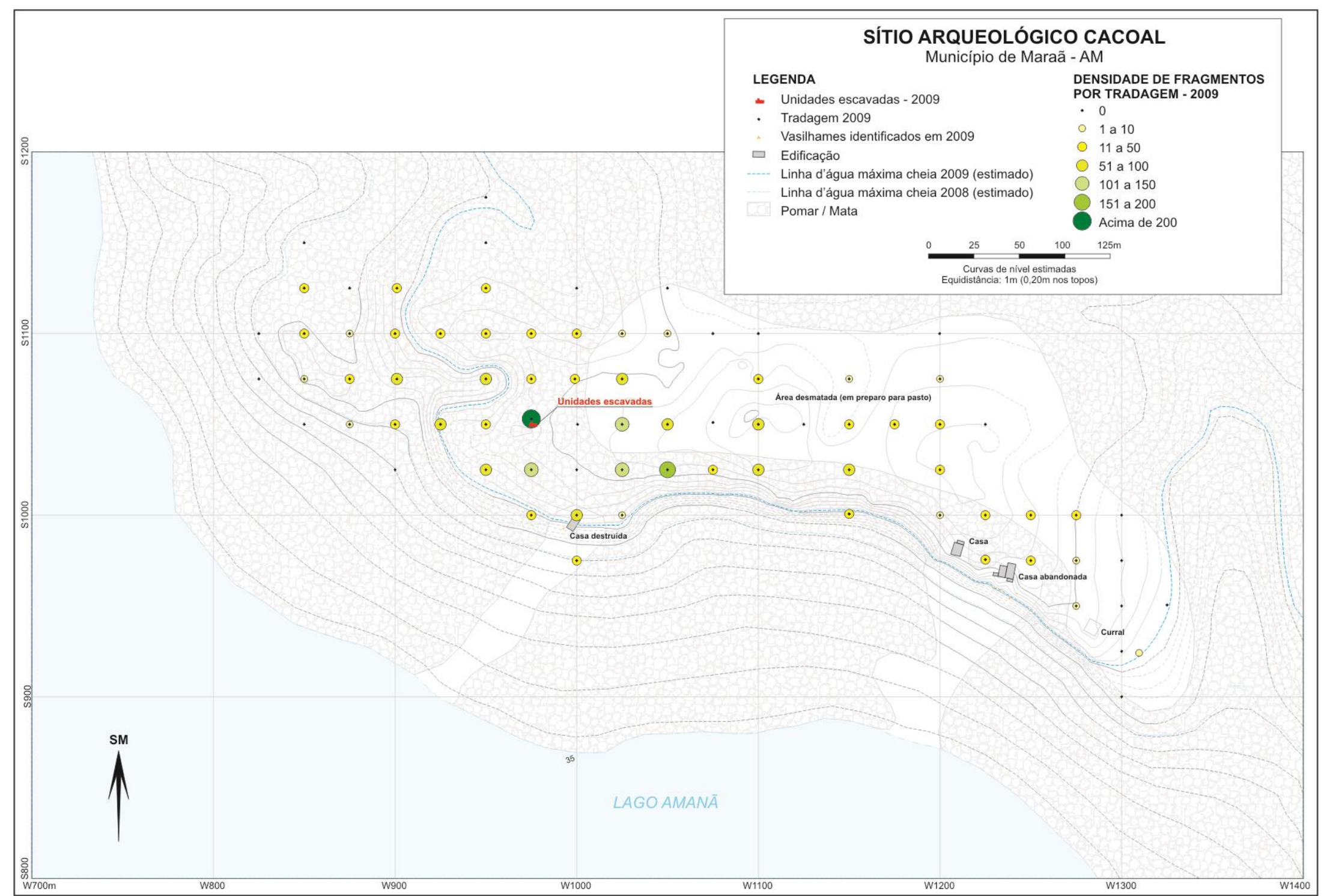

Figura 20: Sítio Cacoal do Amanã, planta topográfica com indicação das intervenções de subsuperfície e densidade de material cerâmico. Marcos Brito. 

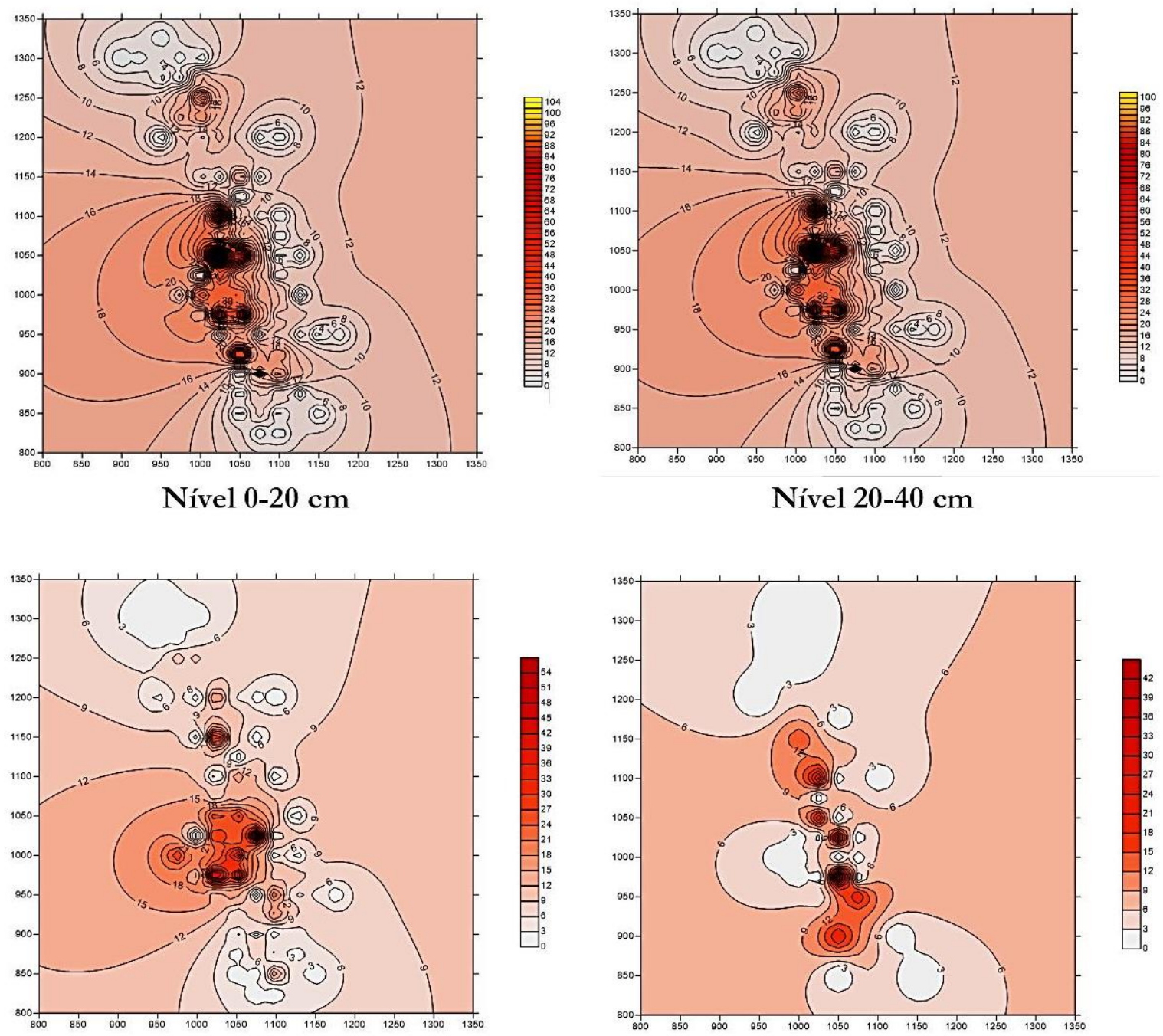

Nível 40-60 cm
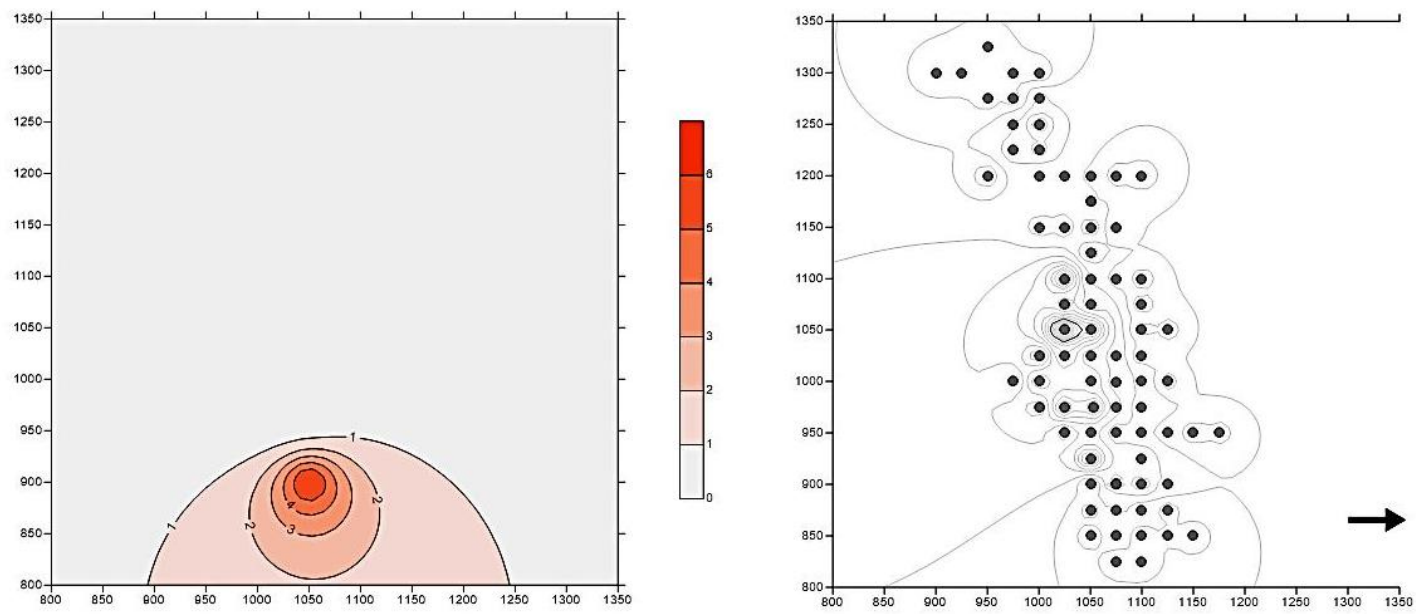

Nível $80-100 \mathrm{~cm}$

Figura 21: Prancha com a distribuição dos fragmentos cerâmicos observados nos diferentes níveis artificiais. Mapa de contorno 2D a partir do conjunto de pontos interpolados resultando em gráficos com curvas delimitando zonas. A escala ao lado apresenta os números de fragmentos. Elaborado por Jaqueline Gomes. Aplicativo Surfer. 
Foi neste ponto que uma trincheira de 4x1 m foi aberta, na área de ocorrência de terra preta e de maior densidade cerâmica que apresentou 200 fragmentos. O registro da escavação dos níveis superficiais caracteriza o solo como arenoso, pouco compactado e coloração 10 YR 4/2, com grande quantidade de cerâmicas que se mantêm relativamente semelhante até os $40 \mathrm{~cm}$ de profundidade, quando manchas de solo começam a ser observadas. Neste momento, os limites são muito indefinidos, mas há variação na coloração do sedimento: 10 YR 3/1 e 6/8 e pequenas manchas de 6/1 (cinza). Aos $60 \mathrm{~cm}$ de profundidade, já em camada de terra preta muito escura (10 YR 3/1) as manchas de solo estéril aumentaram enquanto a quantidade de cerâmicas é a mesma dos níveis anteriores. Neste ponto, o solo é classificado como areno-argiloso, úmido de compactação média, já aos $70 \mathrm{~cm}$ é possível observar claramente o contraste entre solo estéril, quando foram evidenciadas sete feições de formas e tamanhos variados, mas geralmente compostas por cerâmica, bolotas e muitos carvões, essas estruturas receberam tratamento diferenciado, escavadas o interior de modo separado do restante da unidade (Figura 22).

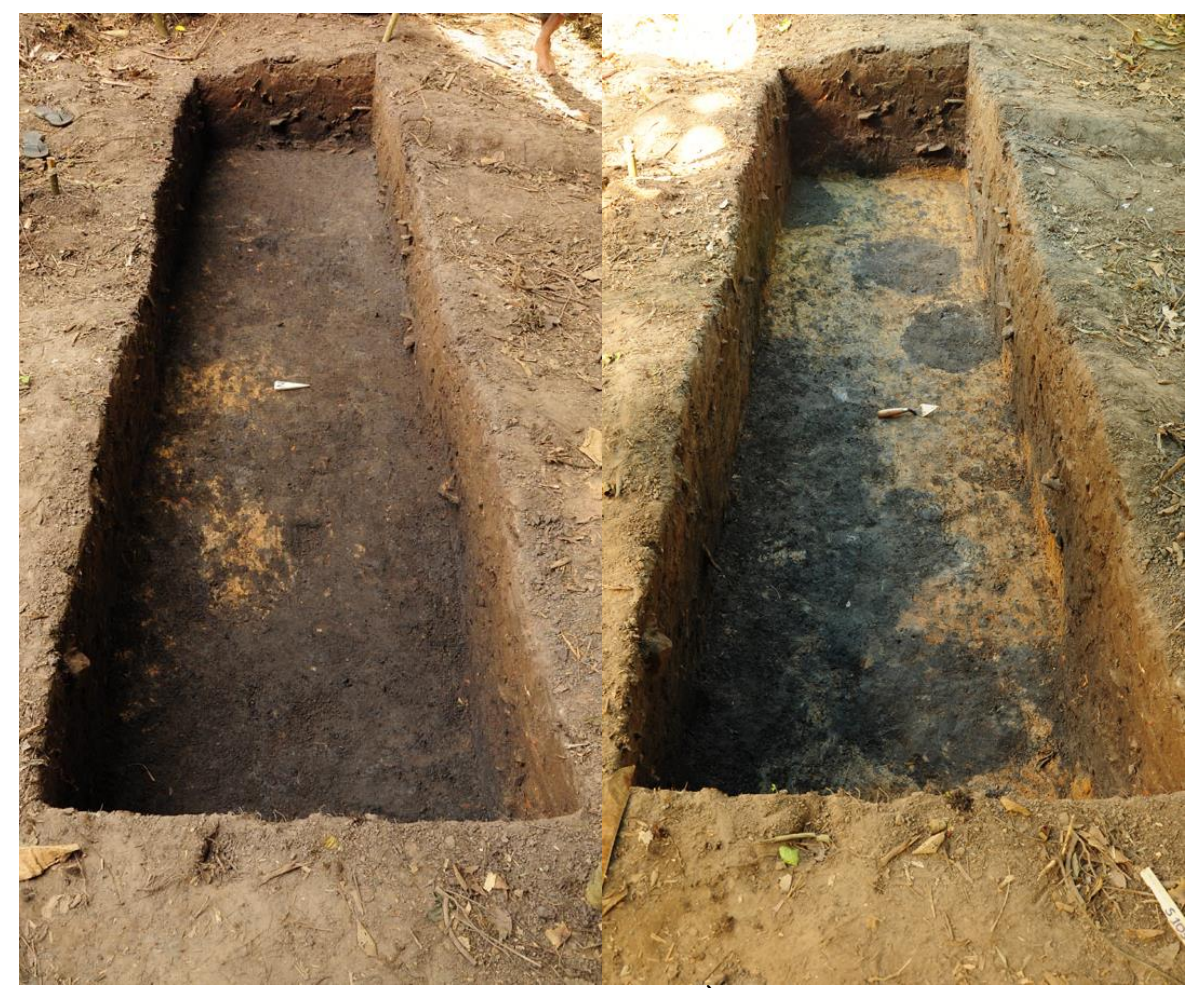

Figura 22: Diferentes etapas de esavação das unidades. À esquerda no nível $30-40 \mathrm{~cm}$ começam a ser observadas manchas de solo estéril, à direita, já na base do nível $60-70 \mathrm{~cm}$, diferentes feições podem ser visualizadas. Fotos de Marilene Ribeiro

Feição 1: Evidenciada na base do nível 70-80, escavada em níveis artificiais de $10 \mathrm{~cm}$ sendo coletadas suas cerâmicas após o solo passar pela peneira. Não foi coletado carvão ou solo. Feição apresentou solo bastante homogêneo em termos de coloração, 
textura e composição, aumentando apenas a umidade conforme a profundidade. Solo arenoso, pouco compactado, coloração 10YR 2/1. Carvões e poucos fragmentos cerâmicos, boa parte deles em posição vertical (PNs: 528, 529, 530, 531). Feição escavada até $117 \mathrm{~cm}$ de profundidade.

Feição 2: Evidenciada na base do nível 60-70, possui aproximadamente $50 \mathrm{~cm}$ de diâmetro. Apresenta solo com textura e coloração muito homogênea. Solo arenoso, pouco compactado. Presença de carvões, cerâmicas e fragmentos de trempe (PNs: 532, 533, 534,535). Mosqueado 10YR 2/1 e 6/1. Muita cinza, a feição pode ser interpretada como uma lixeira queimada rapidamente e com muito oxigênio. O diâmetro é o mesmo em todos os níveis e sua base plana (cilíndrica), atingiu a profundidade de $120 \mathrm{~cm}$.

Feição 3: Muito semelhante a F2, sendo um pouco menor com $40 \mathrm{~cm}$ de diâmetro. Em termos de composição também é semelhante (cinza, cerâmicas e carvão), sua forma é circular com base plana. Atingiu profundidade de $114 \mathrm{~cm}$. PN's: 536, 537, 538.

Feição 5: Escavada a partir da profundidade $100 \mathrm{~cm}$, recebeu o PN 542, possui base irregular aos $104 \mathrm{~cm}$ de profundidade.

Feição 6: Escavada a partir dos $80 \mathrm{~cm}$ de profundidade, possui solo arenoso, pouco compactado. Apresenta cinza em menor quantidade que F2 e F3. Formada por muita cerâmica decorada (Figura 23), bolotas e carvão. Presença de raiz. Sua base de formato plano atingiu a profundidade de $99 \mathrm{~cm}$. PNs: 539540 e 541.

Feição 7: Começou a ser escavada aos $98 \mathrm{~cm}$ de profundidade, possui base plana aos 118 cm, sua composição é semelhante a F1 e F2. PN: 543.

A escavação atingiu $130 \mathrm{~cm}$ de profundidade, sendo evidenciada no perfil S uma grande inversão estratigráfica e uma urna depositada em solo anterior a formação da terra preta. Esta urna recebeu o PN 551 e para sua coleta foi escavada uma área de 1 x 1,5 m contígua ao sul da trincheira (Figuras $24 \mathrm{a} / \mathrm{b}$ ). A urna foi desmontada in situ e escavada em níveis artificiais de $10 \mathrm{~cm}$. No seu interior foram observados fragmentos da tampa e da borda da própria urna, alguns em posição vertical. O seu interior apresentou um sedimento muito úmido, com compactação média e coloração predominante 10YR 2/1, 10YR 6/8 e inclusões de tabatinga. Esse contexto não se modificou substancialmente, exceto a umidade que aumentou com a profundidade e aproximação de sua base. Foram observadas pequenas raízes, fragmentos cerâmicos de diferentes vasilhames, bolotas de argila e carvões, mas nenhum vestígio ósseo. 


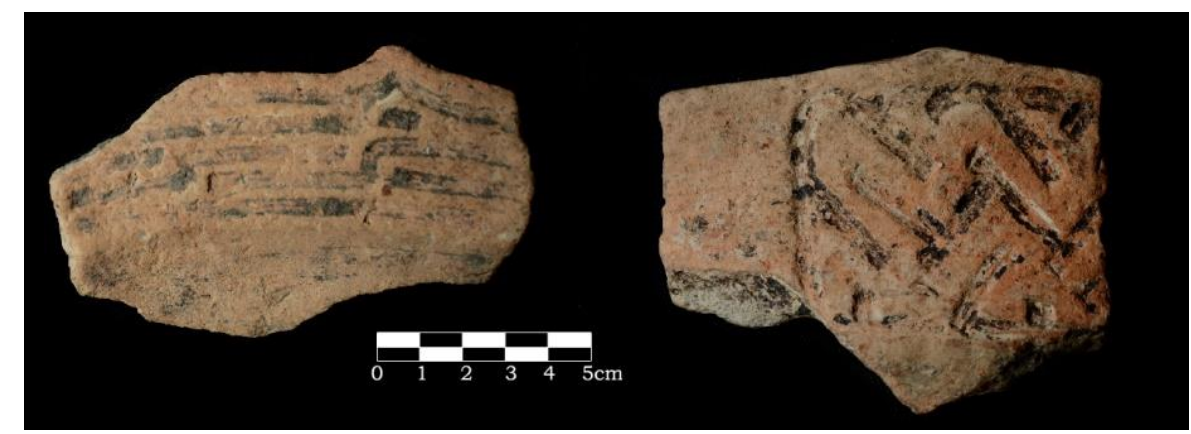

Figura 23: Cerâmica coletada no interior da F6.

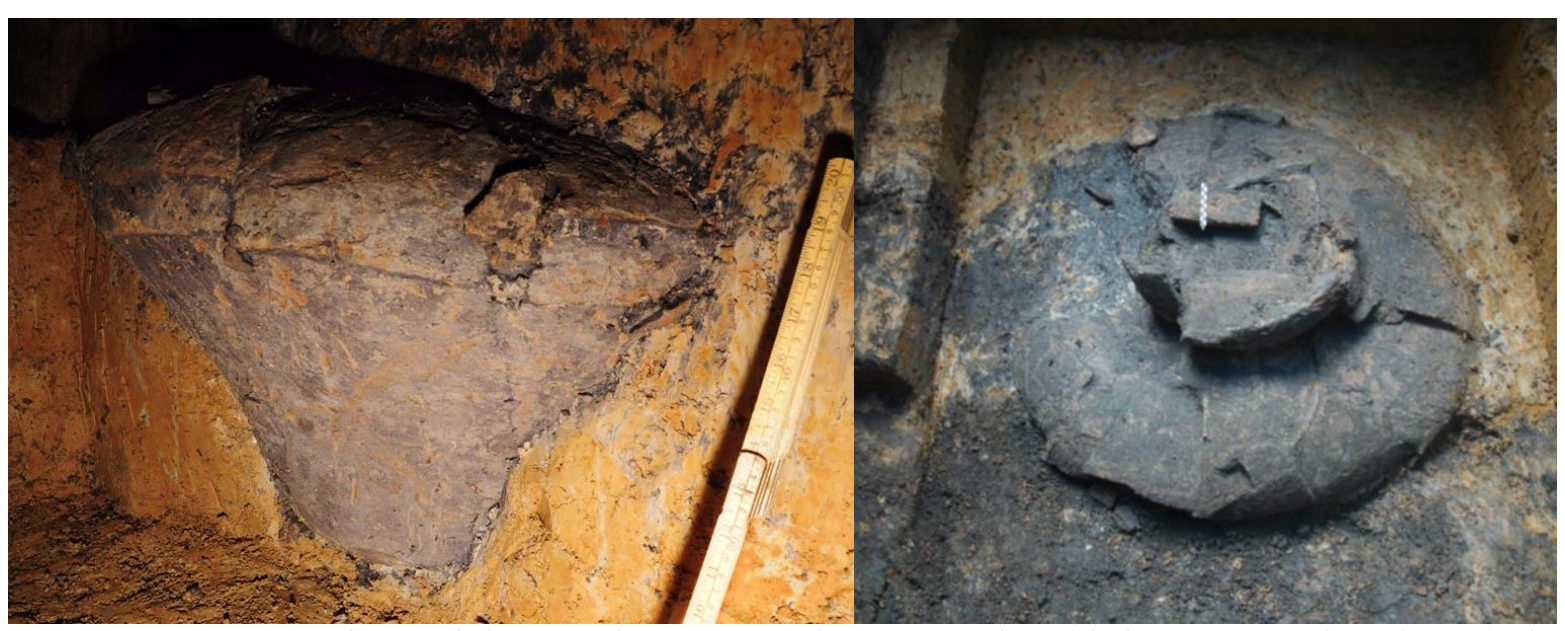

Figura 24: Urna 551 fotografada antes da escavação de extensão da unidade para sua coleta, é possivel observar parcialmente sua morfologia (Foto de Marilene Ribeiro). À direita, evidenciação da urna, após escavação ao sul da unidade de escavação (Foto: Bernardo Costa).

Ao final, as escavações alcançaram a profundidade de 1,92 $\mathrm{m}$, foram coletadas sete amostras de C14 dos perfis estratigráficos que possuem as seguintes características:

Camada I: Solo de matriz argilosa. Camada arqueologicamente estéril. Solo alta compactação, argiloso, coloração 10YR 6/8.

Camada II: Grande quantidade de fragmentos cerâmicos, bolotas de argila queimada, carvões. Nessa camada estão localizadas as feições identificadas na escavação, assim como a urna 551. Solo arenoso, pouco compactado, de coloração escura 10YR 2/1 (Black) com manchas de cinza em algumas feições.

Camada III: Camada arqueológica com média densidade de material. Camada formada pelo solo escavado para a colocação da urna 551. Solo mosqueado entre as colorações $10 \mathrm{YR}$ $6 / 8$ e 2/1. Compactação média, textura areno-argilosa. Em alguns pontos apresenta limites difusos. Camada presente apenas no perfil Sul.

Camada IV: Camada com grande densidade de vestígios, raízes e bioturbações (cupim e formigueiro). Solo arenoso, pouco compactado e coloração 10YR 3/2. 
Camada V: Camada húmica, com muitas raízes e pouco material cerâmico. Solo arenoso e coloração 10YR $3 / 3$ (Figura 25).

$\mathrm{Na}$ tabela seguir, as quatro datações absolutas disponíveis para o sítio ${ }^{19}$. Duas obtidas a partir de amostras de carvões coletados nas bases das estruturas F5 e F6, provenientes do perfil $\mathrm{N}$, sem perturbações da inversão estratigráfica para o enterramento da urna. Foi datado também um fragmento de flange mesial, característico da Tradição Polícroma e um carvão coletado da base da urna PN 551.

\begin{tabular}{l|lllc} 
Amostra & $\begin{array}{l}\text { Proveniência } \\
\text { e material }\end{array}$ & Prof. & $\begin{array}{l}\text { Conventional } \\
\text { Radiocarbon Age }\end{array}$ & N Laboratório $^{\text {o }}$ \\
\hline CAC 545 & $\begin{array}{l}\text { Base de Feição (F3). } \\
\text { Carvão }\end{array}$ & $97 \mathrm{~cm}$ & $1270+/$ - 30 BP & Beta - 294196 \\
\hline CAC 547 & $\begin{array}{l}\text { Base de Feição (F6) } \\
\text { Carvão }\end{array}$ & $77 \mathrm{~cm}$ & $980+/-30$ BP & Beta - 383582 \\
\hline CAC 551 & $\begin{array}{l}\text { Interior de urna. Base. } \\
\text { Carvão }\end{array}$ & base & $1270+/-30$ BP & Beta - 386834 \\
\hline CAC 523.223 & $\begin{array}{l}\text { Nível artificial. } \\
\text { Cerâmica. Caraipé }\end{array}$ & 20-30 cm & $750+/$ - 30 BP & Beta - 383581 \\
\hline
\end{tabular}

Tabela 8: Datações radiocarbônicas disponíveis para Cacoal do Amanã.

\subsection{São Miguel do Cacau}

Sítio cerâmico a céu aberto localizado na margem esquerda do igarapé Cacau que deságua na porção inferior do Lago Amanã. Apenas uma família mora no local onde há um domicilio e uma casa de farinha. Há uma pequena criação de gado e roças. Quando identificado em 2006 calculou-se sua área em $10000 \mathrm{~m}^{2}$, apresentava muitos fragmentos cerâmicos, 2 urnas aflorando na superfície, e segundo informações dos moradores, havia área de terra preta pelo sítio.

Atividades de mapeamento e escavação foram desenvolvidas no ano de $2011 \mathrm{em}$ colaboração com os moradores e somaram um total de 48 intervenções (Figura 26). Foi observada grande quantidade de vestígios cerâmicos diagnósticos das fases Tefé e Caiambé, além de locais de terra preta com até 1 metro de profundidade. O sítio possui 3,10 hectares e na sua porção oeste, onde está situada a moradia da família, foram identificadas 21 urnas aflorando na superfície do terreno. A maior densidade de vestígios ocorre na área mais próxima à margem do igarapé, principalmente na porção NE do sítio ${ }^{20}$.

\footnotetext{
${ }^{19}$ Relatórios das datações podem ser visualizados no anexo 1.

${ }^{20}$ Durante o monitoramento em 2013, foram observadas três concentrações cerâmicas de prováveis urnas, na área de terra preta próximo à casa de farinha e ao local de abertura das unidades de escavação. Houve diminuição no número de urnas na porção oeste do sítio de 21 para 19 (Furquim, 2014).
} 
PROJETO AMANÃ - SÍTIO CACOAL. PERFIS NORTE E SUL. NÍVEL 0-200 cm.
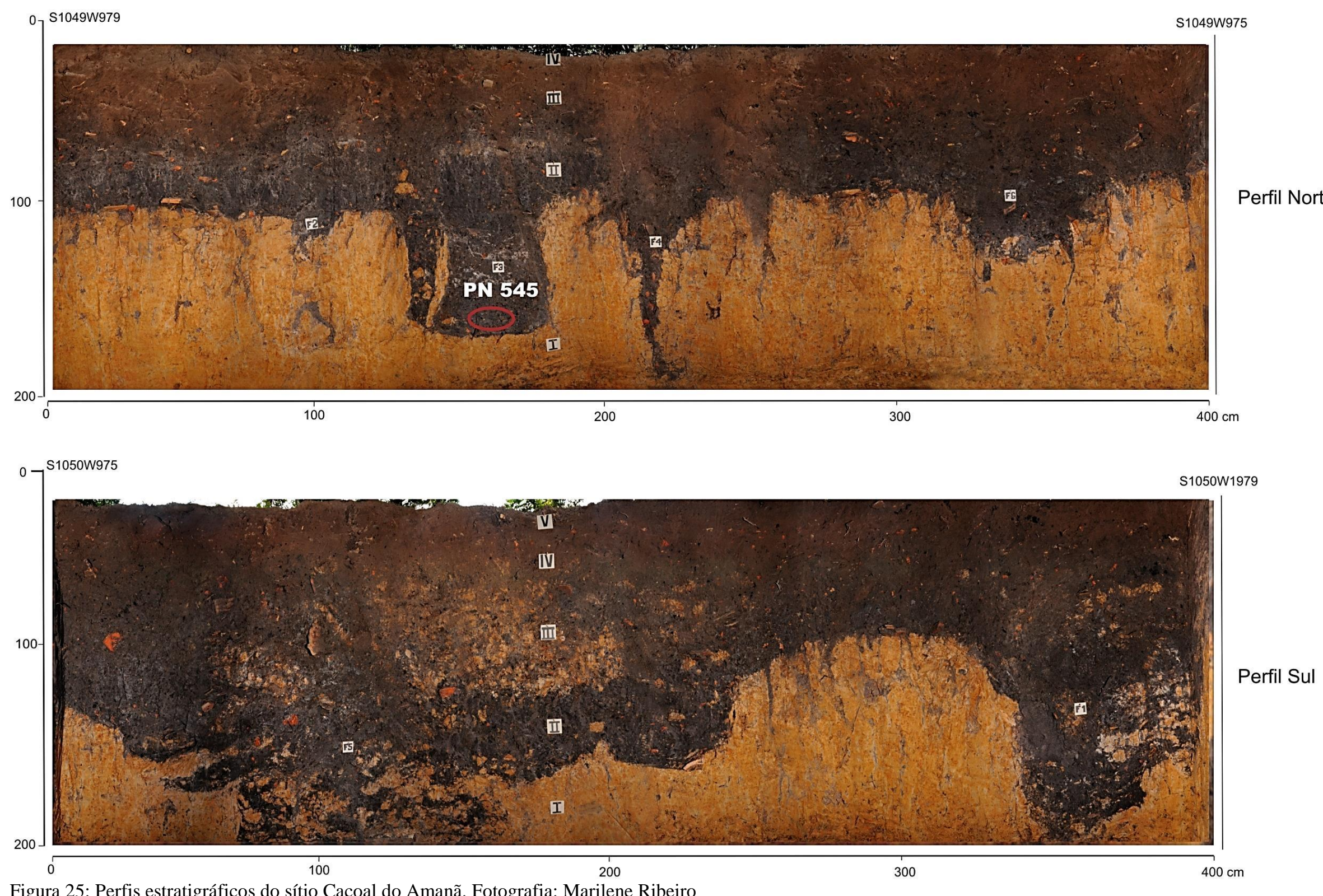


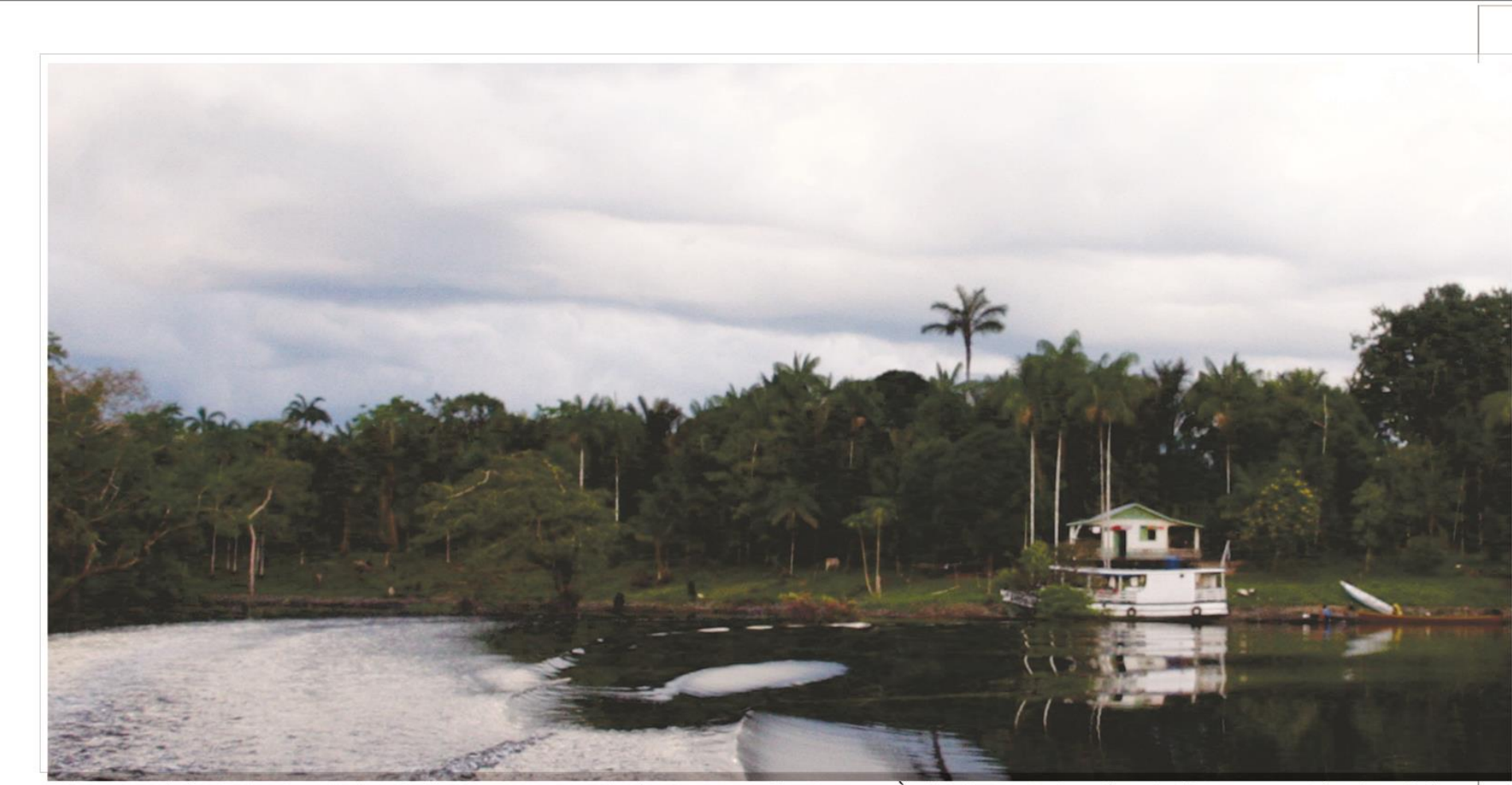

Vista geral do Sítio São Miguel do Cacau a partir do Igarapé do Cacau. À direita o único domicílio construído, local de concentração de urnas ausente de camada de terra preta, à esquerda sistema agroflorestal da família, local de maior densidade do pacote arqueológico.

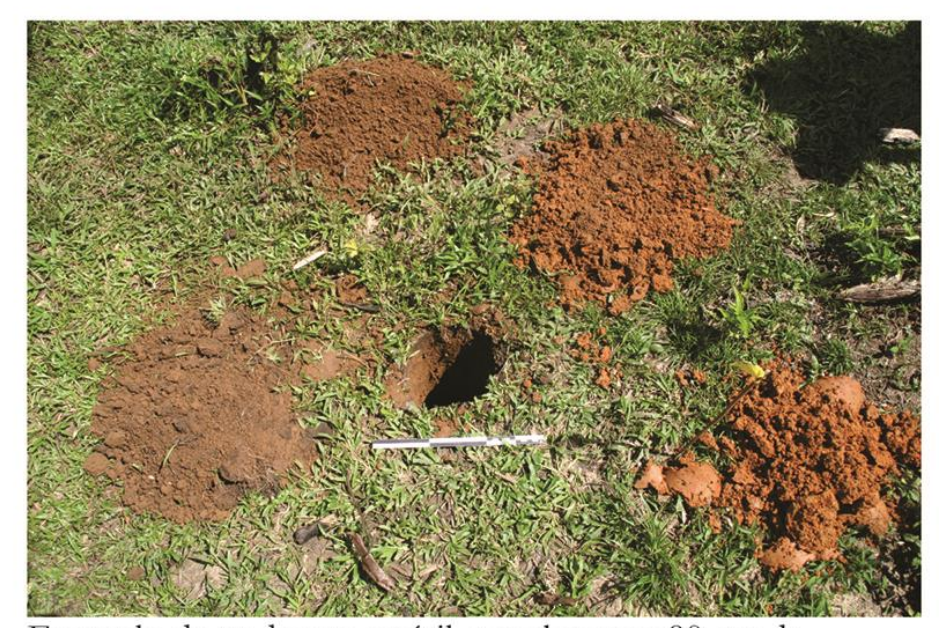

Exemplo de tradagem estéril que alcançou $80 \mathrm{~cm}$ de profundidade.

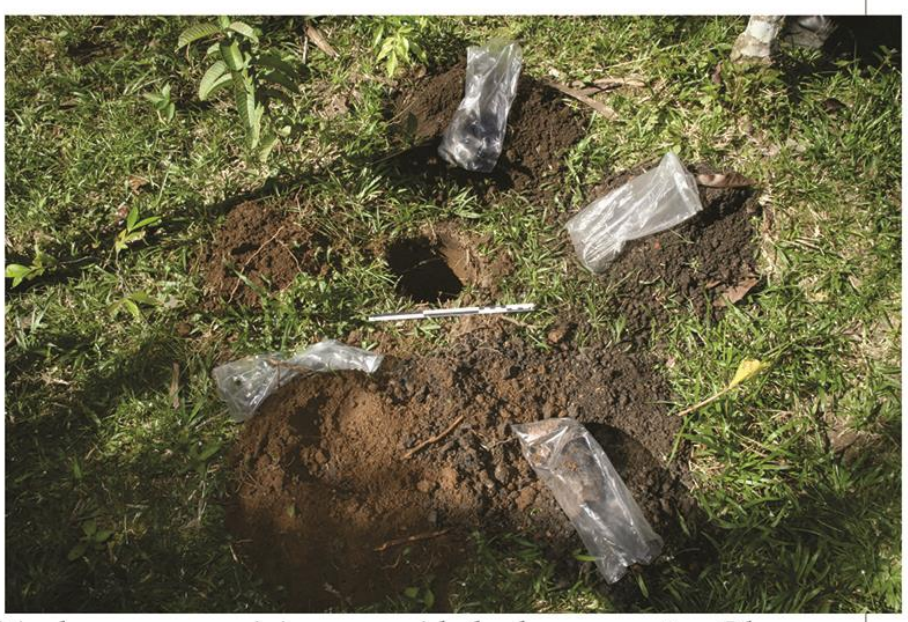

Tradagem que originou a unidade de escavação. Observar

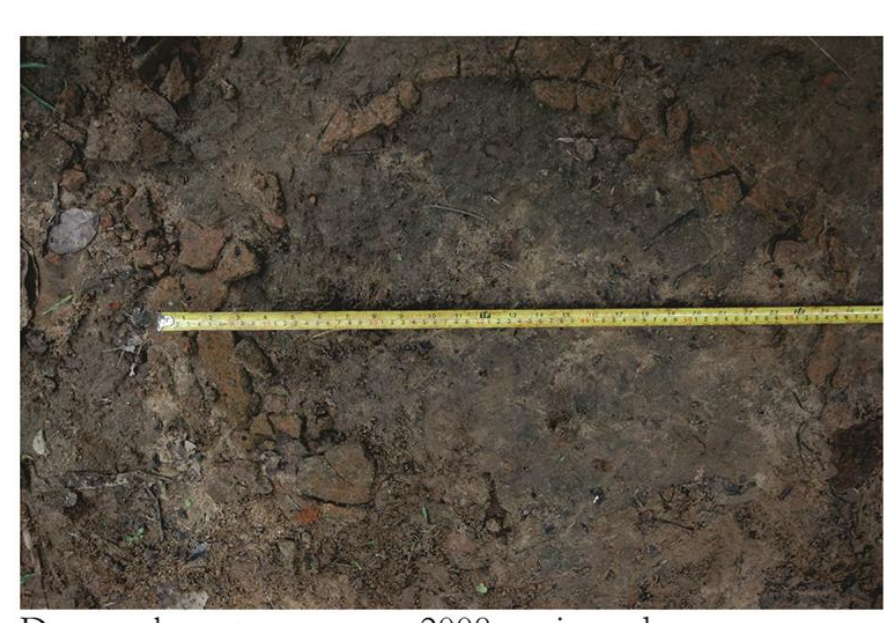

aflorando na superfície do terreno. Foto: Bernardo Costa que os niveis mais superfíciais apres

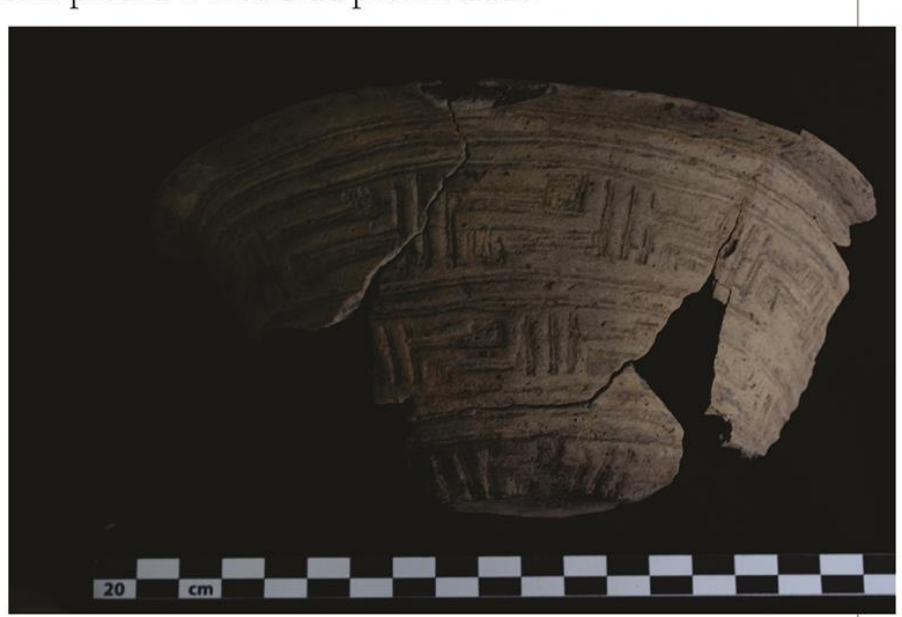

Vaso parcialmente remontado, proveniente da tradagem que originou as unidades de escavação.

Figura 26: Sítio São Miguel do Cacau, planta topográfica e imagens gerais.

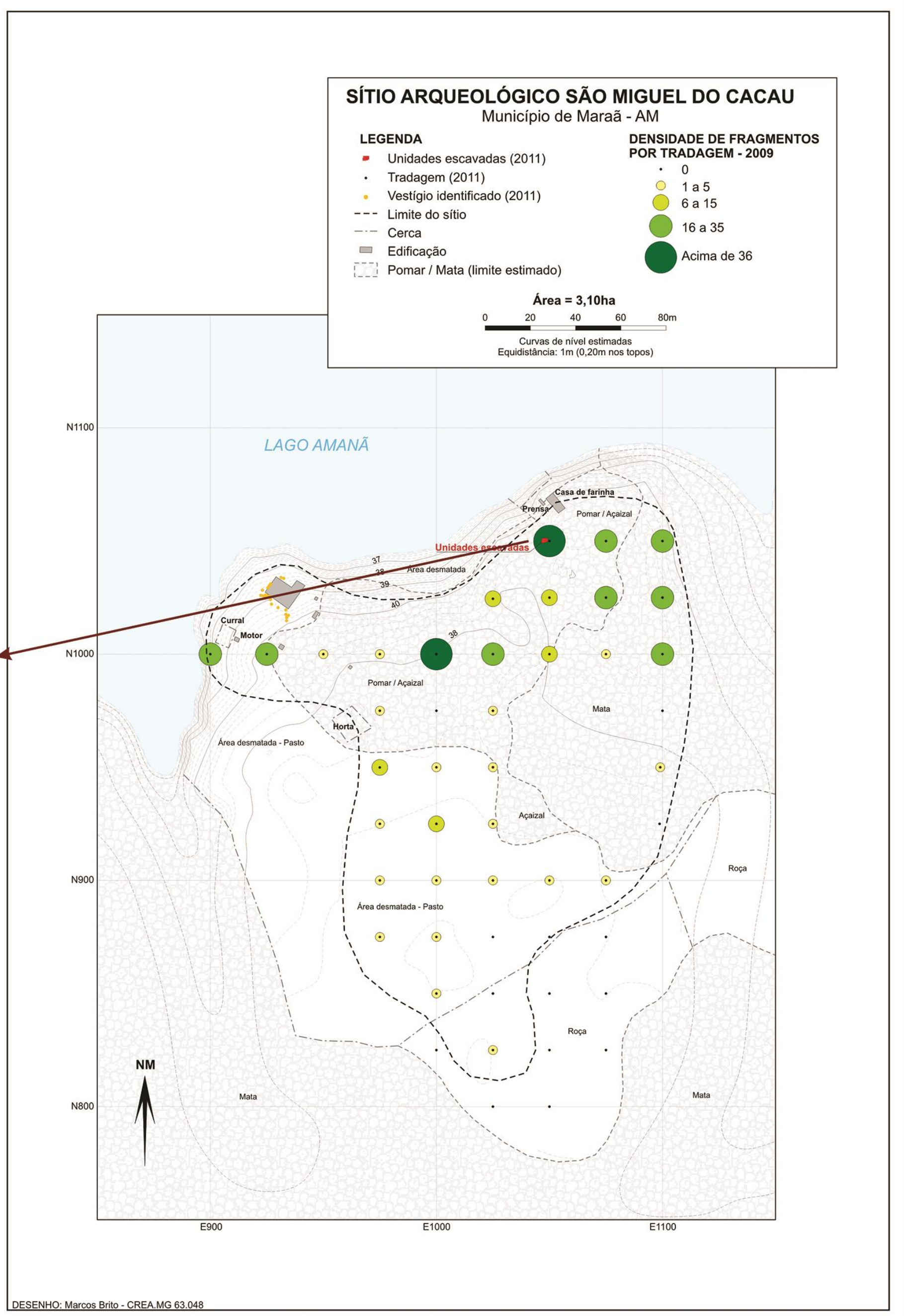


Com o tratamento das informações do mapeamento pelo softwere Surfer, pode-se observar um padrão de distribuição das cerâmicas bastante regular, grosso modo, concentrado na porção nordeste do sítio.
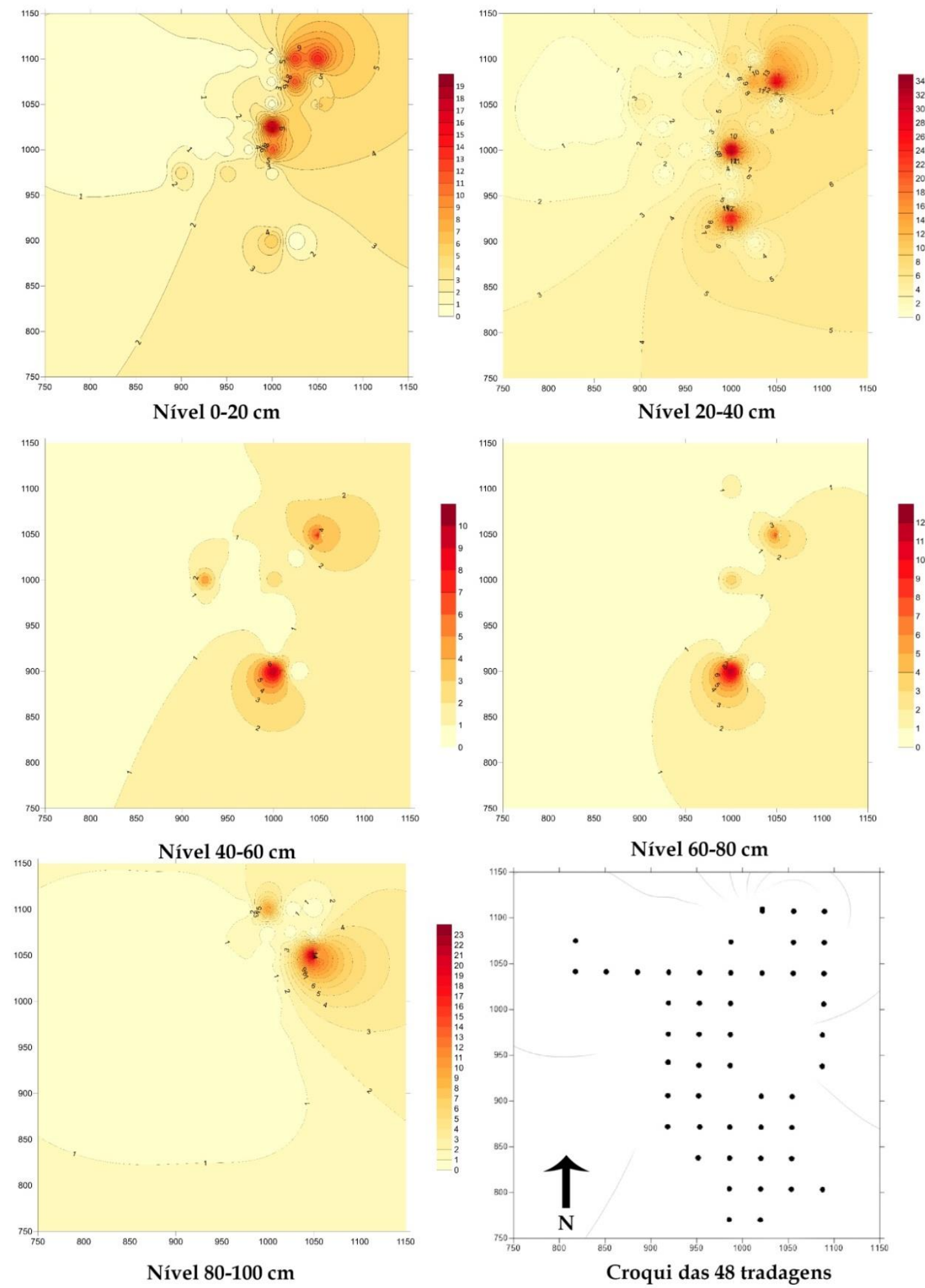

Figura 27: Prancha com a distribuição dos fragmentos cerâmicos observados nos diferentes níveis artificiais. Mapa de contorno 2D produzido através de pontos interpolados. A escala ao lado apresenta os números de fragmentos. 
Considerando a coloração do solo observado nas tradagens, mapas de distribuição do solo foram elaborados seguindo uma proposta semelhante àquela de Guapinadaia e Fonseca (2014).
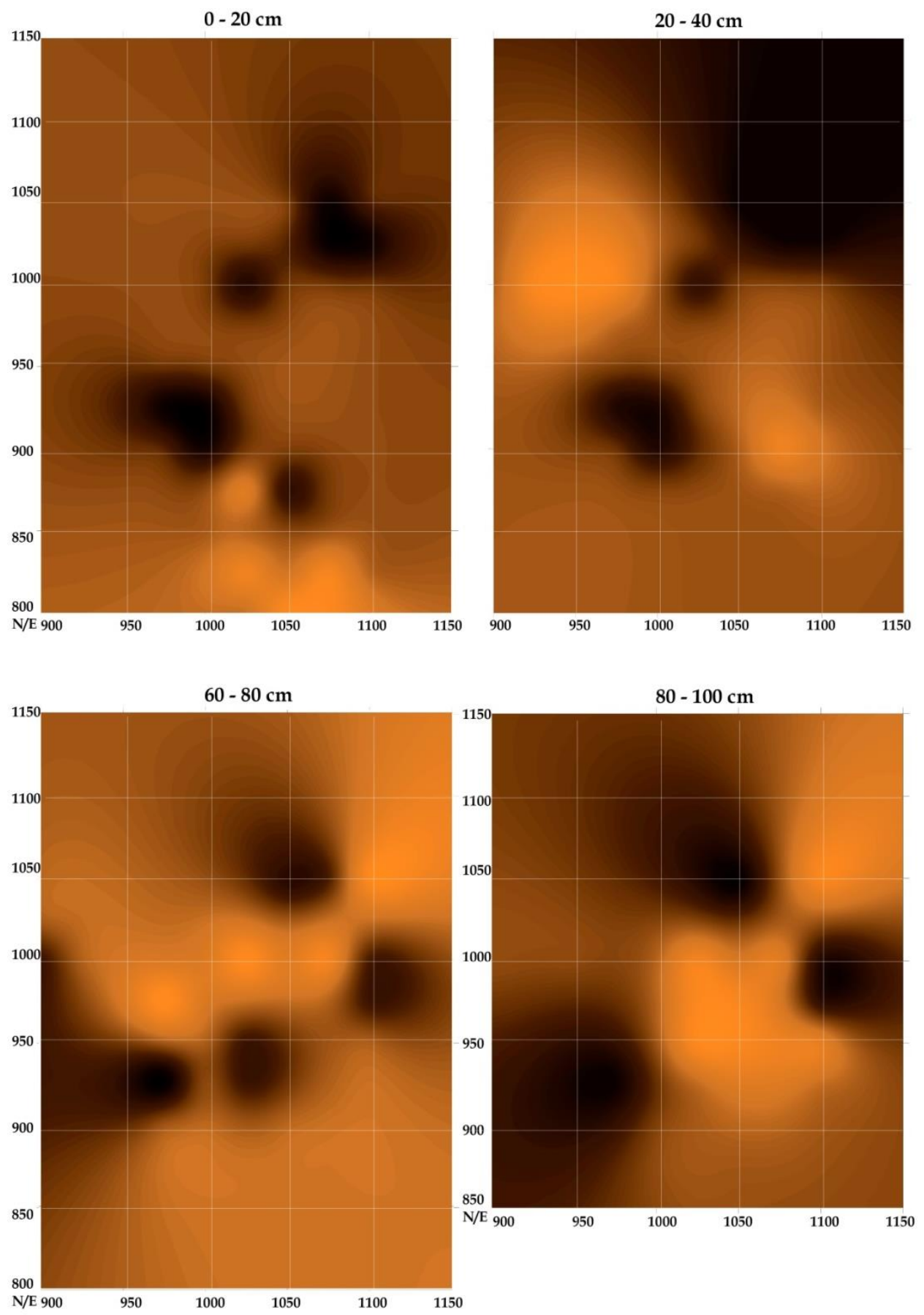

Figura 28: Distribuição da terra preta, a partir das amostras das tradagens, nos diferentes níveis artificiais.

As colorações foram agrupas em quatro categorias e analisadas no programa Surfer através do método de Krigagem, usado em geoestatística para aproximar ou interpolar 
dados, no qual parte-se do princípio que pontos próximos no espaço tendem a ter valores mais parecidos do que pontos mais afastados. A técnica de Kriging assume que os dados recolhidos de uma determinada população se encontram correlacionados no espaço (Soares, 2006).O resultado dessa análise é a visualização da distribuição do solo a cada nível artificial das intervenções de subsuperfície. Percebe-se que até os 40 centímetros de profunidade a presença da terra preta segue o padrão de distribuição cerâmica, onde nos primeiros $20 \mathrm{~cm}$ é possível ver manchas mais ou menos definidas. Já entre os 20 e $40 \mathrm{~cm}$, justamente na porção nordeste, a mancha de terra preta se estende por $150 \mathrm{~m}^{2}$.

A partir dos $40 \mathrm{~cm}$ há uma grande queda na quantidade total de material cerâmico, se restringindo a uma área de aproximadamente 150 metros. Entre 60 e $80 \mathrm{~cm}$ de profundidade, quatro manchas de terra preta são bastante definidas e dispostas de circular ou semi-circular. Aos $80 \mathrm{~cm}$ de profundidade o sítio é praticamente estéril, apenas na porção NW uma tradagem apresentou material cerâmico, mas ainda é possivel ver três machas de solo mais escuro. A partir dessas informações, é possivel hipotetizar sobre a forma da aldeia como circular ou semi-circular, sugerindo assim, que com a continuidade dos trabalhos o retorno ao sítio para a escavação dessas áreas de forma ampla seja realizada.

\subsubsection{As unidades de escavação N1050 E1048-49.}

O sítio São Miguel durante seu mapeamento demonstrou contextos claros e densos de ocupação. Para sua escavação optou-se pela abertura de duas unidades contíguas formando uma área de 2 x 1 m (N1050 E1049 e N1050 E1048), escavadas concomitantemente. A escolha do local foi devido à tradagem N1050 E1050 que apresentou maior quantidade de vestígios e terra preta até 1 metro de profundidade.

$\mathrm{Na}$ área escavada a partir dos $20 \mathrm{~cm}$ de profundidade começou a ser evidenciada no centro da unidade na porção S uma urna que recebeu o PN 572. A partir dos $30 \mathrm{~cm}$ no quadrante SW também começou a ser evidenciada outra urna que recebeu o PN 573. Próximo a ela, aos $40 \mathrm{~cm}$ foi registrada uma feição (F1), cujo solo apresentava uma coloração mais escura que o que o restante das unidades, esta estrutura foi escavada separadamente. Para a coleta das urnas foi necessária expansão de parte das unidades ao sul. Estas urnas foram coletadas com todo seu interior intacto, de modo a preservar os contextos fechados para o tratamento em laboratório. 
Os perfis estratigráficos apresentaram três camadas, com as seguintes características: Camada I: Camada arqueologicamente estéril, solo de matriz argilosa 10YR 6/8 (brownish yellow). Abaixo $60 / 70 \mathrm{~cm}$ da superfície;

Camada II: Camada adjacente à feição I, grande concentração de cerâmicas, carvões e radículas, solo argilo-arenoso 10YR3/3 (dark brown). Entre 10 e $30 \mathrm{~cm}$ de espessura;

Camada III: Camada arqueológica com menor ocorrência de cerâmica e carvões, solo argilo-arenoso 10YR 4/3 (brown). Aproximadamente $20 \mathrm{~cm}$ de espessura.

A estratigrafia e contexto registrados são, em certa medida, semelhantes aos do sítio Cacoal do Amanã. As camadas observadas se distinguem em coloração, não em textura, são mais claras nos níveis superficiais e se tornam gradualmente mais escuras nos níveis profundos, quando há de fato uma mudança abrupta entre a terra preta e o solo argiloso característico da região. Essas distinções tênues, interpretadas ainda em campo como possíveis distintas camadas de ocupação, podem ser também resultado do processo de formação do pacote de solo antrópico, cujos nutrientes poderiam ter migrado para os níveis mais profundos. Esta é uma hipótese que deve ser testada através de estudos geomorfológicos com a continuidade das pesquisas.

De todo modo, em ambos os sítios, a deposição de urnas nas áreas de terra preta, comprometeram sobremaneira as amostras cerâmicas coletadas para fins de estabelecer uma cronologia relativa do sítio. No sítio São Miguel do Cacau, análises posteriores dos registros de campo, indicam uma interrupção na camada arqueológica 2, para o enterramento das urnas, mesmo que não tenha sido observada uma inversão estratigráfica como no sítio Cacoal do Amanã (Figura 15).

\subsubsection{Urna 685}

Durante os trabalhos da equipe de arqueologia na área de abertura das unidades-teste, na porção oeste ausente de terra preta que apresenta a concentração de urnas, um morador começou a escavar uma urna localizada abaixo de sua casa. A equipe de arqueólogos deu continuidade à escavação, realizando a coleta do material cerâmico encontrado no seu interior e a desmontagem da urna in situ. Esta urna recebeu o PN 685, sendo de grandes proporções, com aproximadamente um metro de diâmetro do bojo. Apresentou em seu interior predominantemente um sedimento bastante escuro $10 \mathrm{YR} 3 / 4$, e inclusões de tabatinga e solo claro argiloso que parecia queimado já próximo a sua base. 


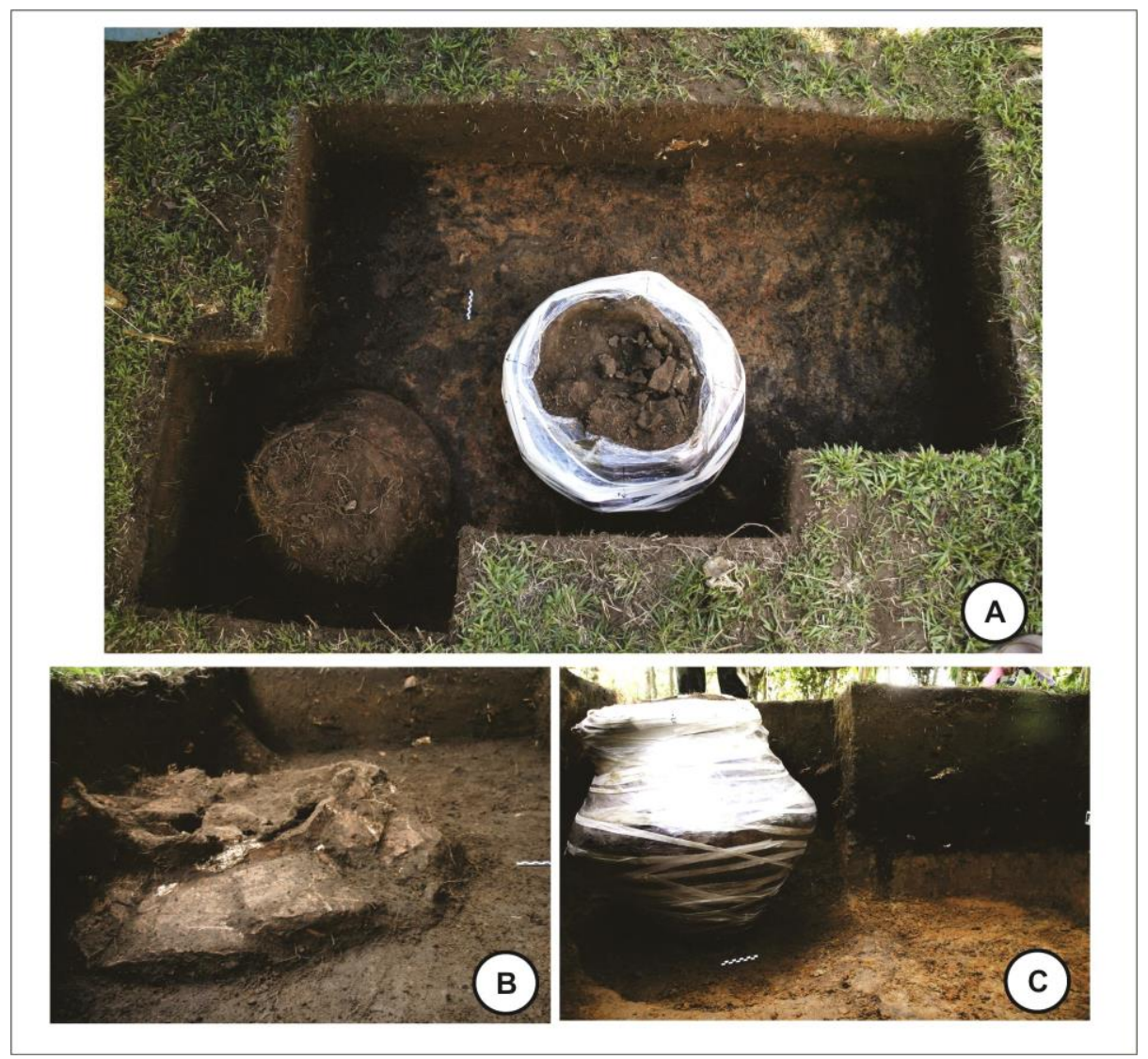

Figura 29: Registro das escavações do sítio São Miguel. A) Unidade com as urnas já expostas; b) inicio da exposição da urna 572, no primeiro plano, atrás já é possivel visualizar a urna 573 começando a ser evidenciada; C) Urna 573 já completamente exposta, ao lado do perfil oeste. Fotos Jaqueline Gomes
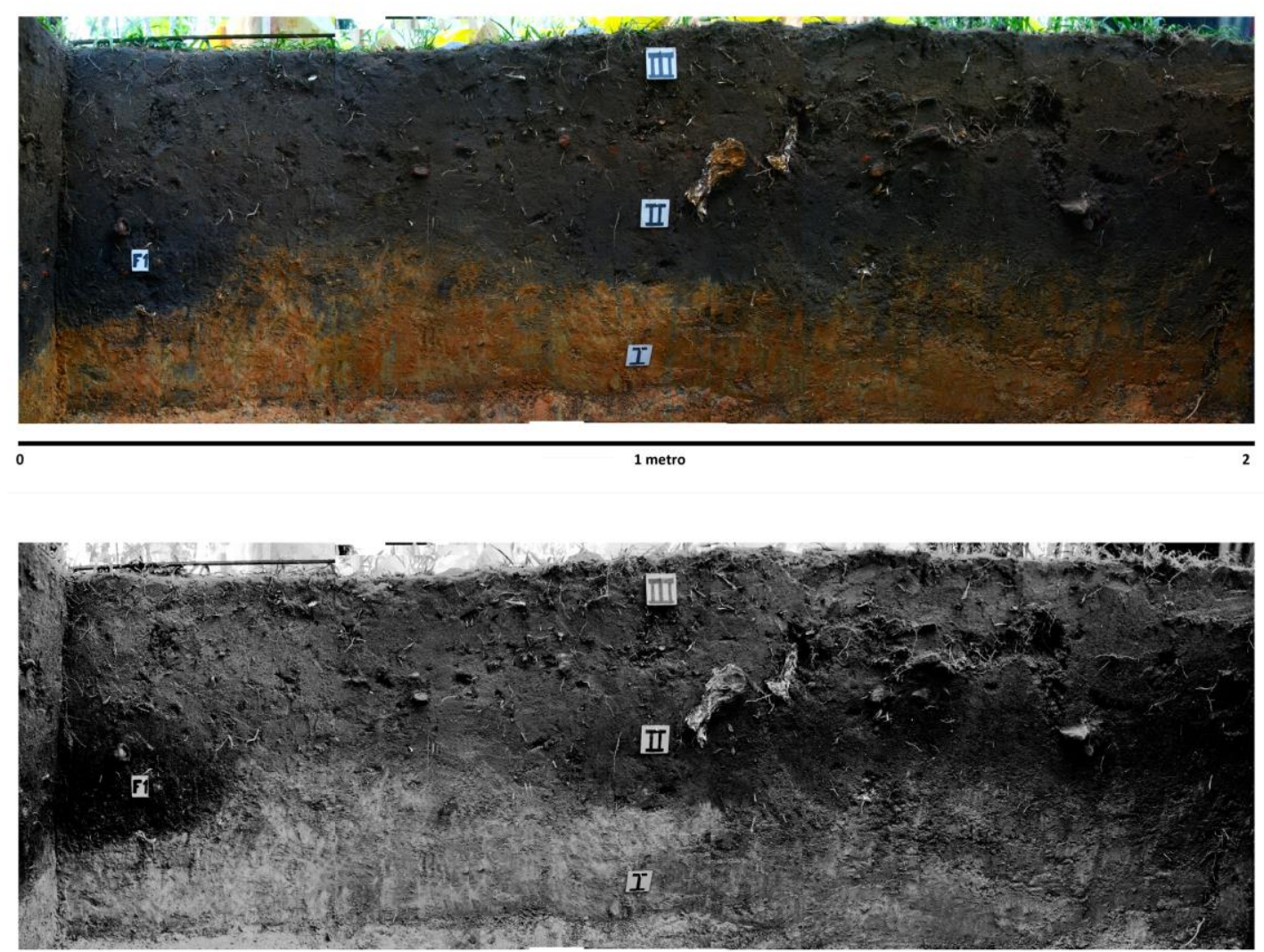

Figura 30: Perfil N, é possível perceber com o tratamento da imagem que a camada 2 e F1, podem ser contínuas, cujo intervalo poderia ser o espaço para deposição da urna 572. Fotos: Jaqueline Gomes 
Foram observados carvões e coletada uma semente carbonizada. O que mais chamou atenção, no entanto, foi a grande quantidade de bolotas de argila e fragmentos cerâmicos de diferentes vasilhames parcialmente remontáveis encontrados no interior da urna. Somando o número de 330 fragmentos, 38\% eram decorados e de dimensões variáveis, alguns maiores de $15 \mathrm{~cm}$. Já no fim da escavação, na base da urna foi coletado um grande fragmento de assador. Ainda em campo a hipótese de aquele contexto ser uma lixeira foi levantada e apontadas semelhanças entre as características do interior do vaso e a feição encontrada na unidade de escavação, principalmente no que se refere a composição desses contextos.
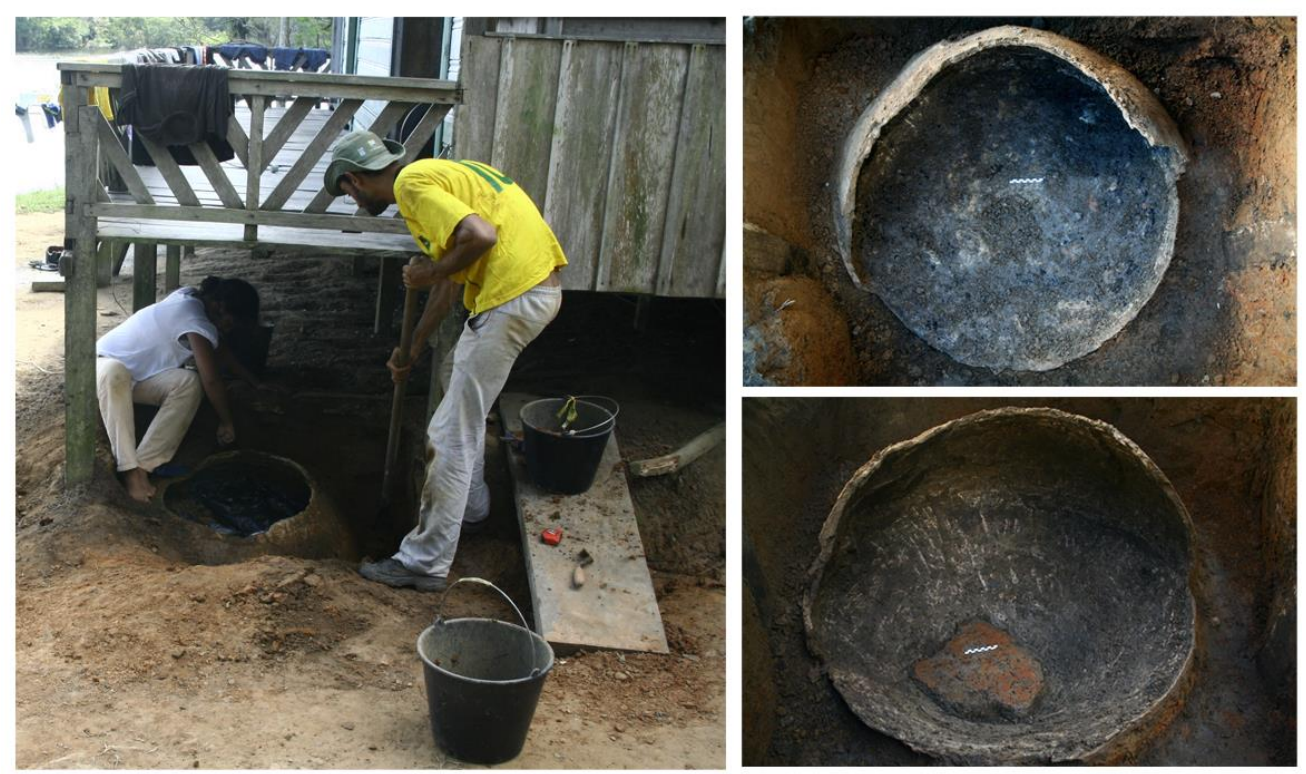

Escavação da urna 685. À esquerda inicio da escavação, observar localização, em solo estéril argiloso. À direita acima, sedimento do interior da urna, presença de muitos carvões. Abaixo: Final da escavação do interior da urna, presença de fragmento de assador.

Na tabela a seguir estão listadas as datações radiocarbônicas obtidas para o sítio. Duas são provenientes de amostras de carvão, coletadas de perfil nas diferentes camadas observadas em campo. Foram datadas com o objetivo de compreender o tempo de formação daquelas camadas. O resultado da amostra da camada superficial foi descartada, pois apresentou uma data muito recente, embora coletada a $35 \mathrm{~cm}$ de profundidade. Do contexto identificado na porção oeste do sítio, amostradas do interior da urna 685, foram obtidas duas datas. A primeira proveniente de um fragmento cerâmico, que acusou uma antiguidade não esperada de 2700 +/- 30 BP (Figura 15/b), e a data de 990 +/- 30 BP obtida de amostra de carvão, que aproxima esse contexto do período de ocorrência da fase Tefé. 


\begin{tabular}{|c|c|c|c|c|}
\hline Amostra & $\begin{array}{l}\text { Proveniência } \\
\text { e material }\end{array}$ & Prof. & $\begin{array}{l}\text { Conventional } \\
\text { Radiocarbon Age }\end{array}$ & $\mathbf{N}^{\circ}$ Laboratóric \\
\hline SMC711 & $\begin{array}{lll}\text { Perfil. } & \text { Camada } & \text { III. } \\
\text { Carvão } & & \\
\end{array}$ & $35 \mathrm{~cm}$ & $150+/-30 \mathrm{BP}$ & Beta - 383584 \\
\hline SMC712 & $\begin{array}{lll}\begin{array}{l}\text { Perfil. } \\
\text { Carvão }\end{array} & \text { Camada } & \text { II. } \\
\end{array}$ & $\mathrm{cm}$ & $1240+/-30 \mathrm{BP}$ & Beta - 383585 \\
\hline SMC684 & $\begin{array}{l}\text { Interior de urna } \\
\text { Próximo a Base. Carvão }\end{array}$ & Interior urna & $990+/-30 \mathrm{BP}$ & Beta - 386836 \\
\hline SMC684.9 & $\begin{array}{l}\text { Urna 685. Cerâmica. } \\
\text { Caraipé }\end{array}$ & Interior urna & $2700+/-30 \mathrm{BP}$ & Beta - 383583 \\
\hline
\end{tabular}

Tabela 9: Datas radiocarbônicas disponíveis para o sítio São Miguel do Cacau.

As datações disponíveis para ambos os contextos, apesar de poucas, indicam que eles podem ter sido produzidos em um intervalo cronológico de 250 anos. No primeiro caso, o enterramento das urnas de fato funerárias e com padrões semelhantes, na área de solo antrópico, possível correlato de áreas habitacionais, cuja data indica uma antiguidade de 1.230 AP. No segundo caso, uma urna (685) foi usada com outros propósitos, com grande quantidade de cerâmicas, carvões e terra preta, depositada em profundidade menor em conjunto com outras urnas, se configurando com um setor distinto daquele habitacional. A data de 990 +/- 30 BP, indica uma antiguidade menor que a área de habitação, mas a morfologia do vaso o associa claramente a Tradição Borda Incisa. Há entretanto, no seu interior ocorrências de flanges mesiais, elementos não encontrados na unidade de escavação, abrindo possibilidades interpretativas para um período de intensa interação cultural na região, já que a primeira vista, é possível que estejamos lidando com um contexto de uso ou reutilização desse recipiente já no período de ocupação Tefé na região do médio Solimões. O contexto Caiambé tem uma ampliação de sua cronologia, já que esta data é próxima daquela de 1.080+-30 BP (890-1.020 A.D.) obtida para fragmento cerâmico associado à ocorrência dessa fase no sítio Boa Esperança.

\section{A contemporaneidade dos assentamentos}

A hipótese apresentada no projeto de pesquisa era que a fase Caiambé representaria o período de maior densidade demográfica no lago Amanã, com a formação de assentamentos contemporâneos em diferentes pontos do lago. Essa hipótese foi formulada tendo em vista as dinâmicas da tradição Borda Incisa na Amazônia Central, nas quais se associam a intensificação dos sítios de terra preta e cerâmicas da fase Manacapuru e Paredão, em aldeias de formato circular, sendo que em alguns desses sítios, as mudanças e manejo da paisagem estão também impressos na construção de montículos artificiais. $\mathrm{Na}$ área de confluência do Negro e Solimões, o aparecimento desse padrão é datado a partir de 500 d.C. e se intensificam por volta de 800 d.C. 
As informações cronológicas e contextuais dos sítios Cacoal e São Miguel, corroboram uma relação positiva entre contemporaneidade dos assentamentos nas porções superiores e inferiores do lago, que apresentam cultura material semelhante (como será mostrado no capítulo 4) e um padrão de formação da aldeia, com espaços específicos para a deposição de urnas, que podem também ser enterradas nas áreas de terra preta, ou seja, possivelmente nas áreas de unidades habitacionais. As duas datas de $1270 \mathrm{BP}$ para a urna 551 e para a feição 3 (Cf Tabela 4), apontam que a produção da terra preta e a deposição da urna se deram em um único episódio de ocupação no sítio Cacoal; já a data de 1240 BP para São Miguel, indica relativa contemporaneidade desses sítios. Ambos os sítios apresentam também datas mais recentes em torno do ano 1000. No sítio Cacoal a feição 6 datada em 980 BP é contemporânea ao contexto datado em 990 BP da urna/feição 685 do sítio São Miguel. Há semelhança estilística do material cerâmico encontrado nelas, onde se destacam padrões gráficos lineares, como aqueles observados nas cerâmicas do interior da urna 685. Mais uma vez, retomo a data de 1.080 BP do sítio Boa Esperança para uma cerâmica associada a fase Caiambé.

Há uma consistência cronológica que nos permite dizer que no período em torno de 700 a 1000 dC, no lago Amanã tenha se constituído diferentes aldeias, algumas contemporâneas, nas quais seus habitantes manejavam de forma mais intensa a paisagem, cujas marcas profundas dessa transformação estão impressas na formação da terra preta, mas não só. Ainda que puramente hipotética, é possível uma relação entre essa intensificação de ocupação e os castanhais, pois parece relevante destacar que próximos a esses sítios estão localizadas essas florestas, um recurso importante e fundamental na RDS Amanã, que a população atual tem sua trajetória histórica marcada por sua exploração. Se observarmos as localizações das maiores comunidades na RDS Amanã, veremos que estão assentadas sobre sítios arqueológicos, em áreas estratégicas de acesso ao lago e igarapés de entrada para ilhas de recursos, seja para caça ou extração. É recorrente a referência aos castanhais como um elemento que motivou o estabelecimento das famílias e posterior formação das comunidades contemporâneas (Gomes, 2011). A associação entre castanhais e a ocupação humana pré-colonial é recorrente na literatura (Balée 1989; Conklin 2001; Pärssinen et al. 2009). A intervenção humana é crucial para o estabelecimento dessas floretas e uma revisão de casos etnográficos sugere como práticas culturais específicas podem ter facilitado a expansão das antigas populações de castanheiras. Especificamente a região de Amanã é contemplada neste argumento (Shepard \& Ramirez, 2011). 


\section{CARACTERIZAÇÃO DA VARIABLIDADE CERÂMICA}

1. A análise cerâmica

A análise desenvolvida nesta pesquisa se baseou em trabalhos sobre cultura material que exploram aspectos da tecnologia e os processos de continuidade e mudança, temas que são o plano de fundo do background analítico construído e revisado continuamente pela disciplina, e que contemporaneamente trata os artefatos em termos de estrutura e agência (Dietler e Herbich, 1998; Hegmon e Kulow, 2005), manutenção e inovação de sistemas tecnológicos (Lemonnier, 1992; Van der Leeuw, 2002; Van der Leeuw e Torrence, 1989;), escolhas tecnológicas e características de performance (DeBoer e Lathrap, 1979; Shiffer e Skibbo, 1997; Silva, 2000); relações de ensino e aprendizagem (Bowser e Patton, 2008) entre outras abordagens.

O objetivo principal foi caracterizar as cerâmicas de modo a evidenciar elementos de continuidade, mudança e/ou inovação, considerando a produção cerâmica mais antiga encontrada na região, classificadas como fases Amanã e Pocó. A análise cerâmica foi realizada em três etapas: i) aplicação de uma ficha de análise com ênfase nos aspectos tecnológicos; ii) formação de conjuntos morfológicos, a partir de desenhos técnicos e reconstituições gráficas; iii) análise do sistema de decoração, com o desenvolvimento de uma ficha específica abarcando atributos como simetria, regularidade e conteúdo gráfico, e posterior teste de sua aplicação.

$\mathrm{Na}$ primeira etapa, a ficha (Anexo 2) aplicada foi desenvolvida pelo Projeto Amazônia Central (Lima, 2008; Machado, 2005; Moraes, 2006; Rebellatto, 2007; Trindade, 2009; Tamanaha, 2012). Ela é resultado de constantes revisões de atributos definidos por diversos autores considerados relevantes para o contexto amazônico (Shepard, 1956; Rye, 1981; Chmyz, 1966; Meggers \& Evans, 1970). O uso dessa ficha permite um nível de comparação com o corpus de informações sobre tecnologia das cerâmicas geradas nos últimos 15 anos na Amazônia Central, e se mostrou bastante satisfatória quando aplicada nas cerâmicas do sítio Boa Esperança após variáveis adaptadas para a região. Com as 
informações geradas a partir dessa ficha, aplicada em todos os fragmentos de bordas, bases, paredes decoradas, apliques e vasos inteiros, realizei um tratamento estatístico descritivo, que buscou relacionar frequências de variáveis no conjunto de fragmentos.

Uma descrição extensa pode ser encontrada em Lima (2008) e Machado (2005) e a avaliação desses atributos para a definição de fases em Moraes (2006). De modo geral a ficha compreende a observação de 21 elementos associados à cadeia operatória de produção do objeto - desde o preparo da matéria-prima (argila e antiplástico) e características da pasta, passando pelas as técnicas de manufatura, as variáveis métricas, tratamentos de superfície, técnicas decorativas e evidências de utilização (Tabela 7).

\begin{tabular}{|c|c|c|}
\hline \multirow{5}{*}{ 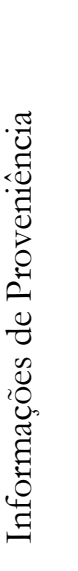 } & Atributo & Definições e variáveis \\
\hline & Sítio & $\begin{array}{l}\text { Informa o sítio arqueológico de origem do material de acordo com o } \\
\text { Cadastro Nacional de Sítios Arqueológicos (CNSA/IPHAN) }\end{array}$ \\
\hline & $\begin{array}{l}\text { Número de } \\
\text { Proveniência }\end{array}$ & $\begin{array}{l}\text { Refere-se ao número de registro do fragmento recebido no momento da } \\
\text { escavação. Um PN pode ser atribuído a uma peça individual ou a um } \\
\text { conjunto de peças de um nível artificial em uma unidade de escavação. Em } \\
\text { laboratório no caso dos fragmentos encaminhados para análise este número } \\
\text { recebe uma extensão numérica que individualiza a peça. }\end{array}$ \\
\hline & Localização & $\begin{array}{l}\text { Todas as intervenções (escavação, sondagens, tradagens) realizadas recebem } \\
\text { um número localizador que está relacionado à malha estabelecida para o sítio. }\end{array}$ \\
\hline & $\begin{array}{l}\text { Nível } \\
\text { estratigráfico }\end{array}$ & $\begin{array}{l}\text { Indica a profundidade em que a amostra foi coletada. Pode ser indicado } \\
\text { através de um nível artificial ou uma profundidade específica. }\end{array}$ \\
\hline \multicolumn{2}{|c|}{ Natureza da peça } & $\begin{array}{l}\text { Constituído por uma lista de variáveis não excludentes, que podem ser } \\
\text { utilizadas de maneira conjugada. O vaso pode ser divido minimamente em } \\
\text { três partes: boca (borda e lábios); bojo (parte de diâmetro máximo da parede } \\
\text { do vaso) e base, mas as peças, quase sempre fragmentadas são classificadas: } \\
\text { 1-Borda; 2- Base; 3-Parede; 4- Inflexão; 5-Alça; 6-Aplique; 7-Fuso; } \\
\text { 8- Flange Mesial; 9- Flange Labial; 10- Vaso inteiro; 11- Artefato } \\
\text { modelado (Estatueta); 12-Carimbo; 13- Asa }\end{array}$ \\
\hline 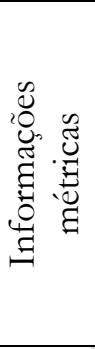 & $\begin{array}{l}\text { Espessura; } \\
\text { Diâmetro; } \\
\text { \% do } \\
\text { diâmetro }\end{array}$ & $\begin{array}{l}\text { Os dados métricos oferecem informações sobre tamanho dos recipientes de } \\
\text { um determinado conjunto. Questões sobre a funcionalidade do vaso podem } \\
\text { ser inferidas através desde atributo. São medidas as espessuras com uso de } \\
\text { paquímetro, sempre na parte mais espessa do fragmento (registro feito em } \\
\text { milímetros). Já o diâmetro é registrado apenas quando o fragmento cuja } \\
\text { curvatura ou projeção tenha dimensões mínimas para a estimativa, que é } \\
\text { orientada por um ábaco e assinalada a porcentagem da curvatura oferecida } \\
\text { pelo fragmento. }\end{array}$ \\
\hline \multirow{2}{*}{ 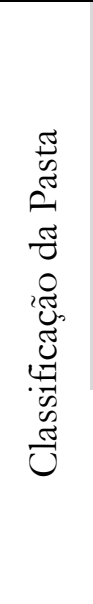 } & $\begin{array}{c}\text { Cor da } \\
\text { superfície }\end{array}$ & $\begin{array}{l}\text { Atributo que indica apenas diferentes colorações de argila, que não } \\
\text { correspondem à diferenças de composição. Essa coloração superficial resulta } \\
\text { de vários fatores além da própria argila, como os processos de queima, } \\
\text { antiplástico, tratamentos de superfície, uso e descarte. Apesar disso esse } \\
\text { atributo pode ser importante para a formação de conjuntos cerâmicos, } \\
\text { quando recorrências de coloração associadas a outros atributos forem } \\
\text { observadas. Foram definidas as seguintes variáveis: } \\
\text { 1-Branca/cinza; 2- Laranja/bege; 4-Preta; 5- vermelha/rosada; } \\
\text { 6- marrom/marrom acinzentado; 7- Laranja forte }\end{array}$ \\
\hline & Antiplástico & $\begin{array}{l}\text { A argila é composta por partículas de sílica, alumínio e água, e sua principal } \\
\text { característica física é a plasticidade. As impurezas mais comuns são quartzo, } \\
\text { hematita e matéria orgânica, elementos presentes à argila ainda em estado } \\
\text { plástico que alteram suas propriedades físicas antes ou depois da queima. Os } \\
\text { antiplásticos funcionam como retentores de umidade que impedem uma }\end{array}$ \\
\hline
\end{tabular}


evaporação rápida da água e confere ao processo de secagem maior estabilidade e diminui os riscos de rachaduras também no momento da queima. Estudos físico-químicos demonstraram que diferentes antiplásticos conferem diferentes performances aos recipientes: os orgânicos oferecem maior leveza e resistência a impactos, já os minerais aumentam a capacidade de aquecimento (Machado, 2005:220). Os antiplásticos foram identificados com auxilio de uma lupa binocular.

1 - Cauixi: uma nomenclatura geral para várias espécies de esponjas de água doce que necessitam de substratos rígidos para se fixarem, sua característica básica é a produção de um esqueleto de espículas de óxido de sílica, que depois de mortas permanecem nos sedimentos dos rios (Volkmer-Ribeiro \& Batista, 2007:134).

2- Caraipé: um termo geral dado às cascas de árvores do gênero Licania spp, também rico em sílica, que passam por um processo de trituração, queima e peneiramento, e é amplamente encontrado nas cerâmicas arqueológicas e contemporâneas (Menegassi, 2009:72).

3-Caco moído: reaproveitamento de fragmentos que são triturados e adicionados à argila. Ainda não foi encontrado na coleção.

4-Quartzo: pode se apresentar como marcadores de funcionalidade do vaso se relacionado com aspectos morfológicos. Os vasos para cozimento quando possuem esse tipo de antiplástico apresetam melhor desempenho.

5-Hematita: confere à cerâmica coloração alaranja e avermelhada.

6-Argila: pequenos nódulos de argila podem indicar seleção menos controlada da matéria-prima.

11-Carvão: quase sempre associado ao caraipé e pode indicar processos mais intensos de queima das cascas.

12-Areia: identificada quando os grãos de quartzo são maiores e mais numerosos, pode indicar em ultima instancia funcionalidade do vaso.

$\begin{array}{ll} & \text { Processo físico-químico que consiste em transformar a pasta em cerâmica } \\ & \text { por meio de elevação de temperatura, durante o qual a maior ou menor } \\ \text { presença de oxigênio determina a oxidação ou redução, que são indicados } & \text { pela textura e cor da cerâmica (Chmyz, 1966, p. 18). A queima redutora deixa } \\ \text { marcas cinzas e escuras na pasta, enquanto a oxidante tende a deixar marcas } \\ \text { mais claras e alaranjadas. A queima é classificada em dois tipos que podem } \\ \text { mostrar combinações entre si: } \\ \text { 1- oxidante; } 2 \text { - redutora; 3 - oxidante interna/redutora externa; } 4 \text { - } \\ \text { redutora interna/ oxidante externa; } 5 \text { - núcleo redutor }\end{array}$


2 - enegrecimento: técnica similar ao polimento, realizada muitas vezes com fuligem adicionada ao verniz ou tinta.

3 - resina: aplicação de diversos tipos de seiva vegetal à superfície da cerâmica

4 - polimento: técnica de complementação do alisado que pode deixar ou não estrias.

5 - Escovado: técnica de imprimir estrias na superfície do vaso.

Contorno do A categoria morfológica geral, definida por três variáveis

Vaso: 1 - simples: os vasos não apresentam nenhum ângulo em sua silhueta.

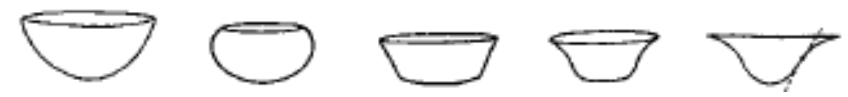

2 - composto: vasos apresentam seções unidas por um ângulo no contorno do vaso ou por uma curva suave, que forma um ponto projetado.

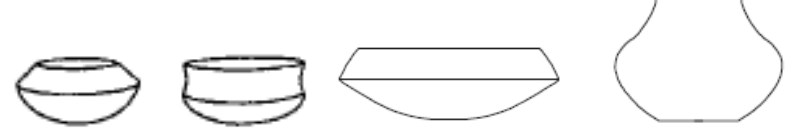

3 - complexo: os vasos apresentam dois ou mais ângulos em seu contorno, ou pontos projetados, que definem a junção de diferentes partes do vaso.
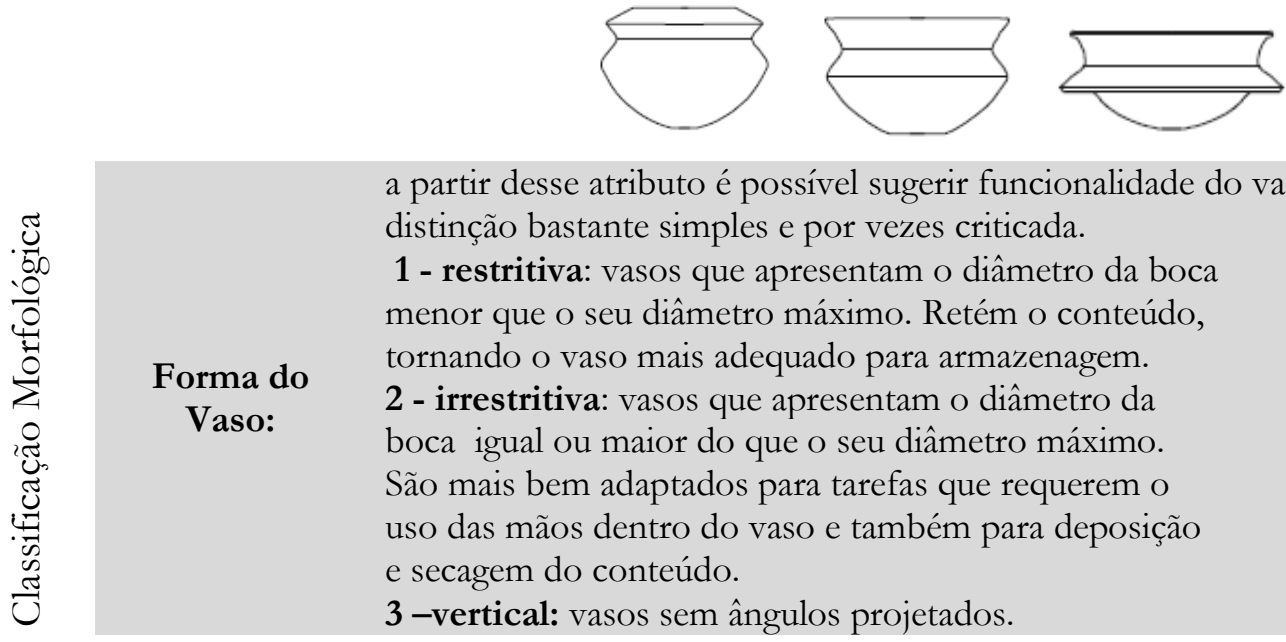

a partir desse atributo é possível sugerir funcionalidade do vaso, uma distinção bastante simples e por vezes criticada.

1 - restritiva: vasos que apresentam o diâmetro da boca menor que o seu diâmetro máximo. Retém o conteúdo, tornando o vaso mais adequado para armazenagem.

2 - irrestritiva: vasos que apresentam o diâmetro da boca igual ou maior do que o seu diâmetro máximo. São mais bem adaptados para tarefas que requerem o uso das mãos dentro do vaso e também para deposição e secagem do conteúdo.

3 -vertical: vasos sem ângulos projetados.

Parte final do vaso. Atributo composto por quatro varáveis

1- Direta: não há nenhum ângulo de inclinação

2- Extrovertida: a peça apresenta extr relação ao ultimo ponto de inflexão ou corp Inclinação da com possibilidade de alteração do volume d Borda 3- Introvertida: a peça apresenta extr relação ao ultimo ponto de inflexão ou corp 4- Extrovertida tipo flange: a peça a] extroversão abrupta em relação ao ultimo pr inflexão ou corpo e não altera o volume do

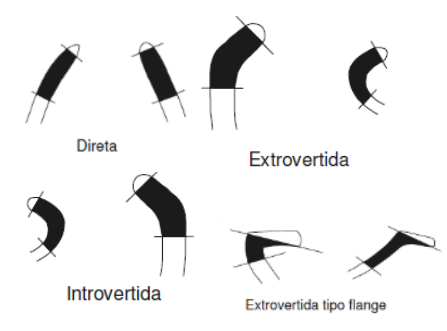

Neste item pretende-se reconhecer as formas mais utilizadas, são variáveis flexíveis, adaptáveis conforme o conhecimento progressivo do conjunto cerâmico. As variáveis usadas na ficha para os sítios analisados foram:

Forma da 3 - Roletada interna; 4 - Roletada externa; 5 - expandido; 6 - Afilada; 10 reta; 11- contraída; 12- Vazada

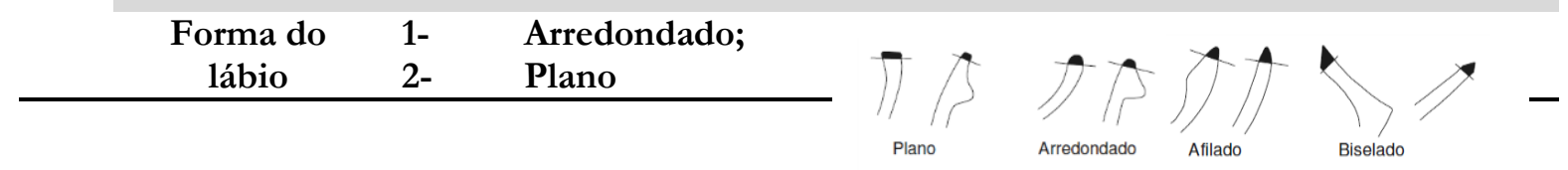




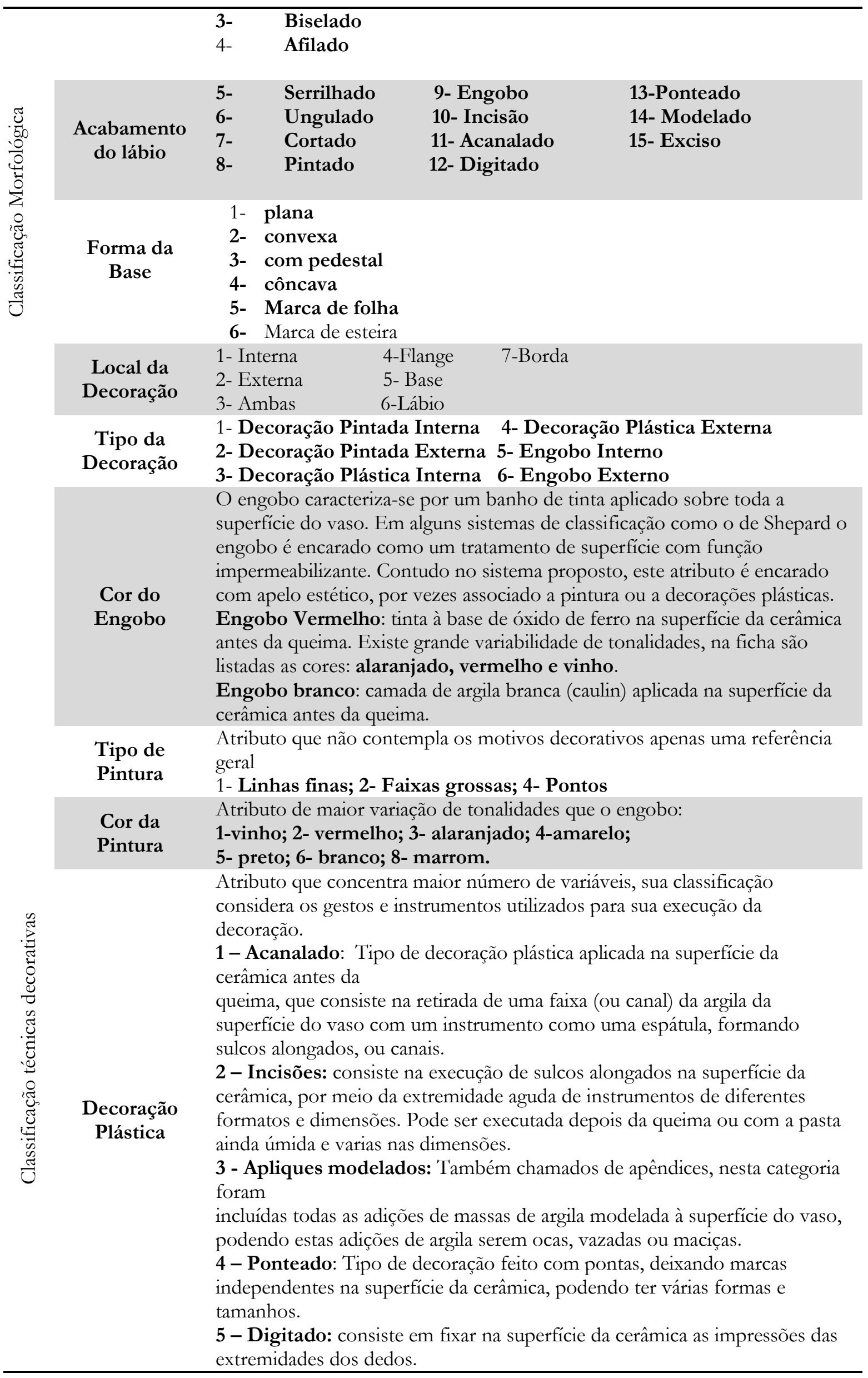


5 - Ungulado: incisões produzidas pelas unhas sobre a superfície da cerâmica.

7 - Excisões: Tipo de decoração plástica obtida através da retirada de áreas de argila da superfície do vaso, produção de efeito de alto ou baixo relevo.

8 - Esferas aplicadas: Consiste na aplicação de pequenos círculos de argila à superfície da cerâmica.

11 - Corrugado: Consiste em imprimir marcas na superfície da cerâmica através da ação contrátil simultânea das pontas dos dedos, em sentido oposto.

12 - Escovado: consiste na aplicação de um instrumento de pontas irregulares sobre a superfície da cerâmica.

13 - Raspagem: retirada de argila com movimento de raspar com um instrumento que deixa estrias ou superfície irregular

14 - Modelagem livre: modelados específicos na própria forma do vaso, quando não se aplica necessariamente a variável 3.

1- Fuligem: vestígios de fuligem presente nas paredes ou bases, de modo que é percebido seu uso no fogo.

\section{3 - Atrito}

Marcas de 4 - Fuligem 2: vestígios de fuligem presente nas quebras do fragmento, uso: $\quad$ portanto associada ao descarte.

5 - enegrecimento: a face apresenta coloração escura, geralmente impregnada, isto é, quando não é possível distinguir uma camada de aplicação de tratamento em si.

A análise da morfologia dos vasos foi realizada com base no conjunto de atributos formais indicados por Shepard (1956) em todos os fragmentos de bordas passíveis de inferência com o principal objetivo de identificar a variabilidade morfológica do conjunto cerâmico amostrado em cada sítio. Os desenhos técnicos incluem informações métricas do diâmetro da borda, inferido através de um ábaco. Esses desenhos foram posteriormente digitalizados, e as formas dos vasos foram reconstituídas graficamente em programa de desenho vetorial.

A terceira e última etapa compreendeu: i) a seleção e registro a partir de desenhos, fotografias e decalques de peças passíveis de análise dos elementos gráficos; e ii) a observação, a partir de uma ficha específica de atributos para os aspectos formais da decoração. Se na primeira etapa os atributos decorativos estão relacionados de uma manneira genérica, para verificar a frequência de técnicas e como ocorrem, na terceira etapa, essess atributos embora não sejam tratados em seus aspectos simbólicos, são considerados como índices de escolhas culturais específicas. Buscou-se assim alcançar a maneiras como as técnicas e o conteúdo gráfco são realizados, através de análise que se debruça sobre a estrutura de composição dos motivos e identificação do repertório gráfico. Motivo gráfico é aqui entendido como forma estilizada que compõe um sistema gráfico. Isto é, um motivo é a combinação precisa de elementos gráficos distintos (linhas retas ou curvas, pontos, círculos, etc). A combinação e disposição de motivos configura por sua vez, 
um padrão gráfico, cujo ritmo e simetria - ou assimetria - singularizam um estilo artístico. O esforço de usar tais conceitos procura superar as noções de representação e relações icônicas, majoritariamente aplicadas nas análises de decoração das cerâmicas.

Em tese, o levantamento e sistematização do repertório gráfico, permite evidenciar mudanças e continuidades, através de análise baseada em um conjunto de distinções por vezes sutis, mas, analiticamente essenciais. Essas distinções são classificadas com base nos padrões conhecidos, e, conforme sua ocorrencia, são tratadas como: i) anomalia, isto é, um design incomum, que se desvia da norma e pode ser detectado como tal e que é posteriomente incorporado ao repertório gráfico; ii) anomalia isolada, que se refere a desenhos incomuns que não são incorporados e, portanto, tiveram pouco ou nenhum efeito sobre a tradição. Para Hegmon \& Kulow (2005), o principal foco de análise são as inovações e a investigação se concentra sobre o processo de introdução, aceitação, disseminação e declínio de elementos decorativos nos conjuntos cerâmicos.

A ficha foi elaborada a partir da eleição de atributos com ênfase nos aspectos formais. Em grande parte uma adaptação da ficha de análise de design de Hays (1992) usada para diferentes mídias: petroglifos, cerâmicas e têxteis. Contudo, avaliei a aplicação das variáveis apenas para a cerâmica, com ênfase em dois aspectos: tratamento das linhas e simetria. No primeiro caso, essas variáveis são úteis para identificar estilos diferenciados, especialmente nos casos em que a técnica de decoração não restringe os tipos de linhas e curvas que podem ser produzidos. Com base nas definições de Hatcher (1974) que esses atributos e variáveis foram considerados.

No que se refere à simetria, há uma produção bastante extensa sobre sua identificação e uso em arqueologia, mas parecem fundamentais. As proposições de Shepard (1948; 1956), quando há prioridade em determinar os graus e tipos de simetria nas cerâmicas, e os trabalhos de Washburn e Crowe (1988) Washburn (1987; 1983) que se debruçaram sobre a estrutura da simetria também em outros tipos de materiais como os têxteis. Essas autoras definem um fluxograma detalhado para a identificação de movimentos que constituem a simetria de um design e oferecem um sistema de notação internacional, testei a aplicação do fluxograma e tive êxito embora à natureza fragmentada da amostra. O sistema de notação de Washburn não foi usado, pois é equivalente aos sete tipos de simetria classificados por Shepard (1948), e avaliei este último como mais elucidativo. Maiores detalhes são apresentados abaixo, junto à descrição dos atributos e variáveis da ficha. Por fim, de maneira geral, procurei identificar os movimentos utilizados para a construção dos desenhos e detectar modificações e transformações da ocorrência dos elementos gráficos. 
Ficha de análise das unidades e padrões gráficos (Anexo 3)

\begin{tabular}{|c|c|}
\hline Atributo & Definição e variáveis \\
\hline Suporte da decoração & $\begin{array}{l}\text { A parte específica do vaso onde é aplicada a decoração, considerando } \\
\text { as categorias conforme a etapa } 1 ;\end{array}$ \\
\hline Condição da peça & $\begin{array}{l}\text { Se está inteira, se é um fragmento, ou está colado/remontado } \\
\text { parcialmente }\end{array}$ \\
\hline Estado de conservação & $\begin{array}{l}\text { Avaliado em graus de } 1 \text { a } 5 \text {, onde } 1 \text { é um grau muito baixo e } 5 \text { alto. } \\
\text { Superfície onde está a decoração analisada: } \underline{\text { interna ou externa. }}\end{array}$ \\
\hline $\begin{array}{l}\text { Informação da técnica } \\
\text { decorativa }\end{array}$ & $\begin{array}{l}\text { Aqui são basicamente as mesmas variáveis que na ficha da primeira } \\
\text { etapa, mas qualifica mais detalhadamente o tipo de incisões se simples, } \\
\text { duplas ou múltiplas. }\end{array}$ \\
\hline Morfologia genérica & Esférica, semi-esférica, vertical, com gargalo, irregular. \\
\hline Contorno do vaso & Simples; composta; complexa (Shepard, 1956) \\
\hline $\begin{array}{l}\text { Distribuição dos } \\
\text { elementos gráficos }\end{array}$ & $\begin{array}{l}\text { Considerando a forma genérica do vaso, identifica como campo } \\
\text { decorativo é constituído (Hatcher, 1974: 43-44). Onde é possível } \\
\text { detectar se a forma restringe o uso de um determinado motivo ou não. } \\
\text { Se uma padronização é encontrada, a distribuição do campo } \\
\text { decorativo pode caracterizar estilos particulares (Hays, 1992: 163). As } \\
\text { variáveis desse atributo são: Centro: o campo decorativo está limitado } \\
\text { no meio do objeto. Descentralizado: os elementos aparecem perto } \\
\text { da borda do vaso. Intermediário: inclui bandas em torno da parede } \\
\text { lateral de um vaso Periférica: o campo decorativo é a borda externa } \\
\text { do vaso, flange labial. Total: quando toda ou várias partes da } \\
\text { superfície do vaso recebe decoração. }\end{array}$ \\
\hline
\end{tabular}

Centro

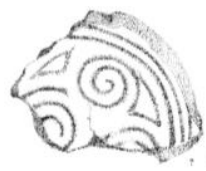

Descentralizado

Intermediário

Periférico
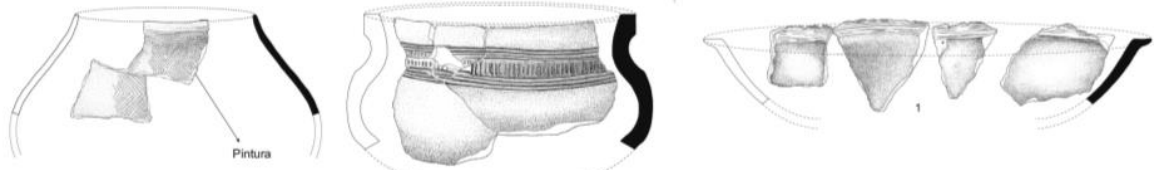

Figura 31: Distribuição da decoração a partir de amostras da Amazônia Central (Lima, 2008; Moraes, 2013)

Conteúdo do desenho Identificação do conteúdo do desenho - auxiliada por uma lista de unidades gráficas que foi construída conforme o avanço da análise. A partir dessa identificação que o restante da ficha foi preenchida.

Lista com desenhos

Grau de linearidade Se o design pode ser totalmente reproduzido sem preencher todas as áreas ele é linear (Hatcher, 1974: 93). Portanto, um desenho foi considerado linear quando ele se restringe a uma faixa de unidades gráficas (ziguezagues, triângulos abertos, linhas de Z, V, L, círculos concêntricos, espirais); não-linear, quando isso não ocorre e intermediário, quando são identificadas divisões entre elementos que formam um único motivo.

Escala de linearidade Diz respeito ao tipo do motivo, se curvilíneo ou retilíneo, indo respectivamente de uma escala de 1 a 5 . O desenho é curvilíneo quando se inclui círculos, espirais, volutas e linhas onduladas. Desenhos retilíneos incluem ziguezagues, triângulos, retângulos, linhas retas ou escalonadas, unidades gráficas como " $z$ ", "v". "L".

Escala de acabamento Avaliado por uma escala de 1 a 5, sendo 1 arredondado e 5 reto. dos cantos

Grau de regularidade Também mensurado por uma escala de 1 a 5 , respectivamente, baixo e do traço alto. Esse tipo de observação é interessante, pois permite avaliar a precisão com que o artesão executava a decoração, o que de certa maneira, permite vislumbrar sua experiência e o controle da técnica.

Relação figura e fundo Definida pela observação da tensão entre o desenho e seu contexto, 


$\begin{array}{ll}\text { Graus de simetria } & \text { exemplo, um tabuleiro de xadrez. } \\ & \text { Baseado nas definições de Shepard (1948; 1956), de modo a mensurar } \\ & \text { se os motivos eram ou não construídos levando em consideração } \\ & \text { regras de simetria. Neste caso, esse atributo não substituiu a } \\ & \text { identificação de classes de simetria, que nesta análise é chamada de } \\ & \text { estrutura da simetria. } \\ \text { Eixos de simetria } & \text { Observação de como o elemento gráfico se repete, se através de um } \\ & \text { eixo vertical, horizontal ou diagonal (transversal). } \\ \text { Padrão: } & \text { Há um número finito de classes de simetria que podem ser divididos } \\ & \text { em três categorias (Washburn e Crowe, 1988: 20): } \\ \text { 1) desenho finito: design com base no movimento em torno de um } \\ \text { ponto. 2) banda ou faixa (desenho unidimensional): movimento ao } \\ \text { longo de um único eixo, com sete possíveis simetrias. } \\ \text { 3) desenho bidimensional: movimento ao longo de dois ou mais } \\ \text { eixos, com dezessete possíveis simetrias bidimensionais. }\end{array}$
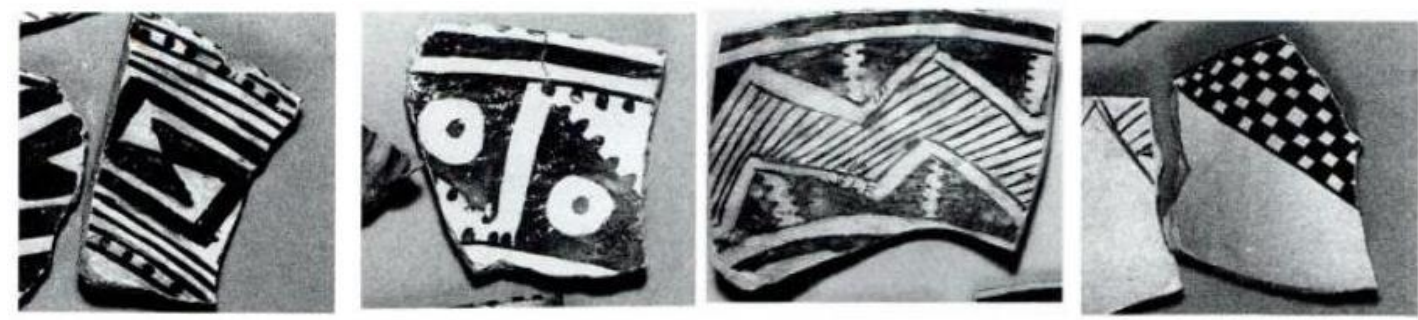

Figura 32: Da esquerda para direita, exemplos dos tipos de padrões: Motivo finito em um fragmento Mesa Verde preto sobre branco; Motivo finito em um fragmento McElmo preto sobre branco; desenho em banda/faixa (unidimensional) em um fragmento santa Fé preto sobre branco; Padrão bidimensional em um fragmento sudoeste americano. Todas as fotos são de Doroty Wasburn publicadas em Washburn e Crowe, 1988.

Grupos de simetria

Movimentos
Este item é uma referência aos estudos de Barcelos Neto (2008) que aplica uma análise formal semelhante àquela desenvolvida por Gell (1998). O que é interessante é que a simetria pode não estar no desenho como um todo, mas existir simetria em alguns pontos dele. Aqui procurei determinar se havia grupos de simetria.

Trata exatamente dos movimentos usados para construir a simetria, sua base é matemática definida pela distância entre as partes que é, em teoria, sempre a mesma. Estes movimentos são:

1. Reflexão: uma repetição refletida em um plano; 2 Rotação: a repetição se dá em torno de um ponto no plano; 3.Translação: a repetição do elemento ao longo de uma linha; 4. Translação com reflexão: a repetição através do deslizamento do elemento ao longo de uma linha, seguida pelo seu espelhamento. 


\section{$\triangle O A \cos ^{\circ} \otimes \cos ^{3}$}

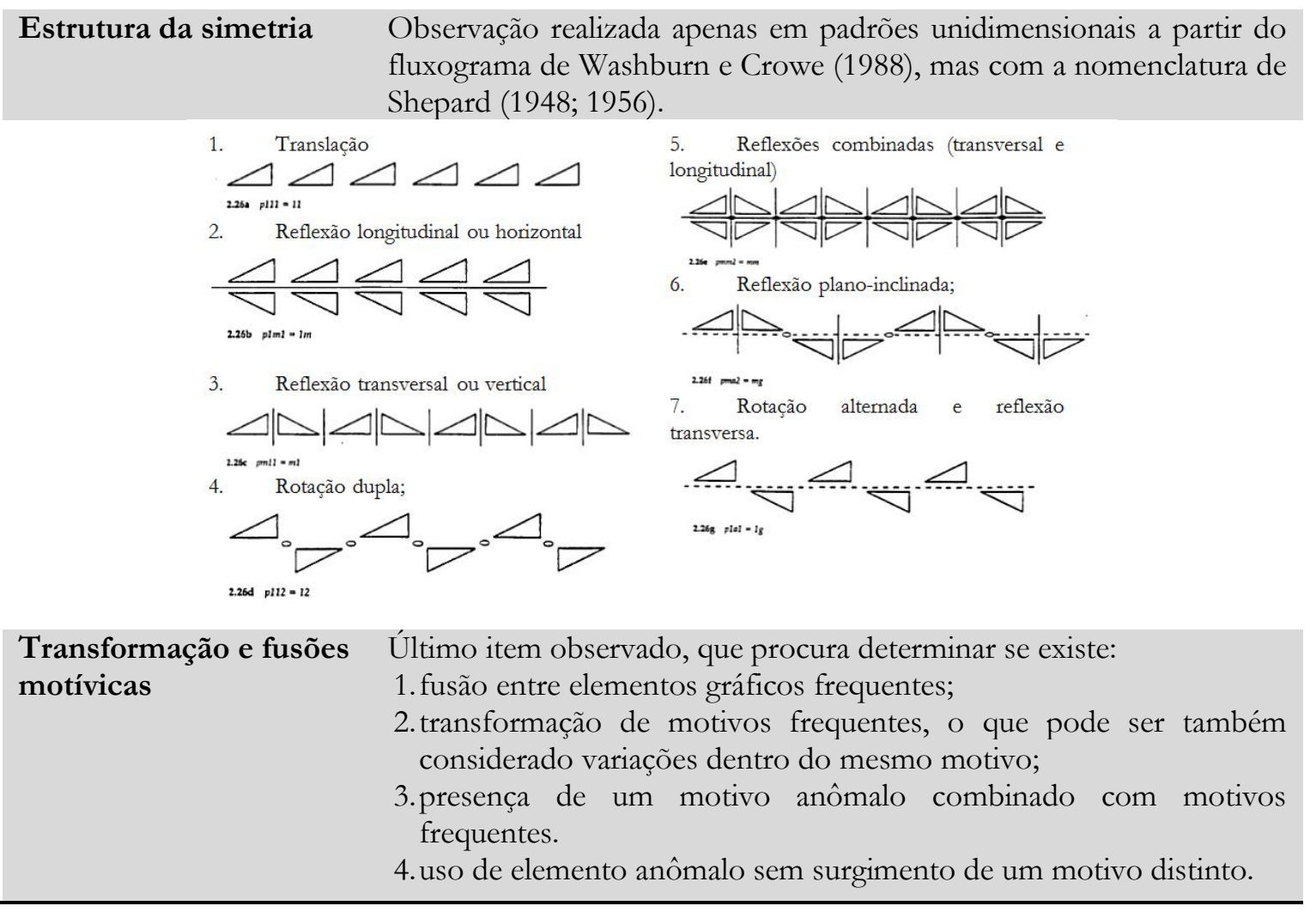

Fluxograma de Washburn e Crowe para padrões unidimensionais

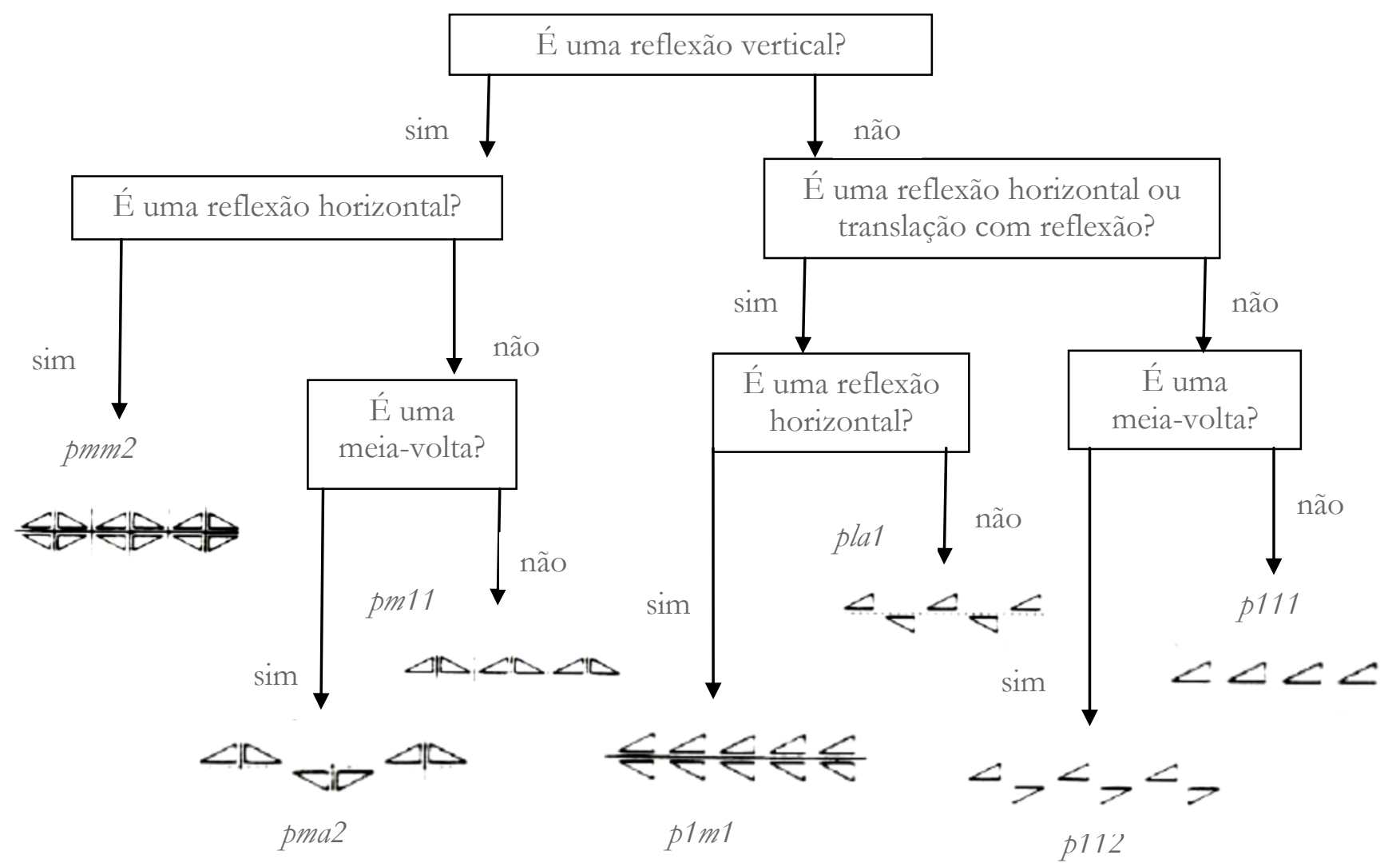


2. Caracterização da cerâmica.

2.1. A amostra: triagem e quantificação

Os procedimentos anteriormente descritos foram aplicados nas amostras dos sítios Cacoal do Amanã e São Miguel do Cacau, ambas constituídas basicamente de fragmentos cerâmicos, alguns passíveis de reconstituição parcial e um número reduzido peças inteiras.

Toda a amostra foi triada nas categorias de borda, borda decorada, base, parede decorada, parede sem decoração, flange mesial, apêndices/apliques e bolotas de argila. Em ambos os casos os fragmentos receberam curadoria inicial ainda em campo, isto é, foram lavados, triados e pesados. Quando no início das análises em laboratório, passaram por uma segunda etapa de limpeza e numeração.

No sítio Cacoal do Amanã, foram coletados 6.293 fragmentos cerâmicos nos níveis artificiais e feições, destes 1.354 fragmentos foram encaminhados para análise, cerca de $18 \%$ do total coletado.

\begin{tabular}{|c|c|c|c|c|c|c|c|c|c|c|c|c|c|}
\hline Conjunto Nível & $\begin{array}{c}\stackrel{\overbrace{}}{1} \\
\stackrel{d}{ }\end{array}$ & $\begin{array}{l}\stackrel{\rho}{\rho} \\
\stackrel{\rho}{\rho}\end{array}$ & 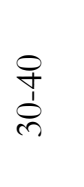 & $\begin{array}{l}0 \\
\stackrel{n}{1} \\
0 \\
0\end{array}$ & $\begin{array}{l}\stackrel{0}{0} \\
1 \\
0 \\
i n\end{array}$ & $\begin{array}{l}\stackrel{0}{P} \\
0 \\
0\end{array}$ & 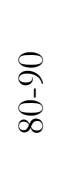 & 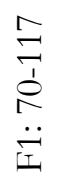 & 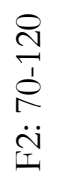 & $\begin{array}{l}\stackrel{+}{\beth} \\
\vec{d} \\
\ddot{D} \\
\ddot{\sim}\end{array}$ & 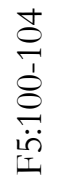 & 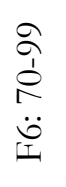 & 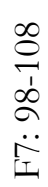 \\
\hline Borda decorada & 69 & 72 & 79 & 59 & 48 & 28 & 14 & 3 & 8 & 4 & 6 & 11 & 0 \\
\hline Borda. s. decor. & 71 & 60 & 51 & 42 & 65 & 28 & 11 & 4 & 9 & 1 & 0 & 5 & 0 \\
\hline Base & 30 & 27 & 26 & 18 & 19 & 10 & 9 & 2 & 5 & 1 & 0 & 2 & 0 \\
\hline Parede decorada & 45 & 66 & 77 & 53 & 52 & 37 & 25 & 5 & 14 & 4 & 1 & 21 & 0 \\
\hline Parede. s. decor. & 1050 & 810 & 819 & 730 & 774 & 430 & 104 & 41 & 58 & 26 & 8 & 84 & 5 \\
\hline Apênd./Aplique & 18 & 13 & 6 & 5 & 4 & 1 & 3 & 0 & 0 & 0 & 0 & 1 & 0 \\
\hline Estatueta/Fuso & 2 & 1 & 0 & 3 & 0 & 0 & 0 & 0 & 0 & 0 & 0 & 0 & 0 \\
\hline Total & 1285 & 1049 & 1058 & 910 & 962 & 534 & 166 & 55 & 94 & 36 & 15 & 124 & 5 \\
\hline
\end{tabular}

Tabela 10: Sítio Cacoal do Amanã: triagem da cerâmica

Já no sítio São Miguel do Cacau foram coletados 1.671 fragmentos cerâmicos nos níveis artificiais, feição e extensão aberta para a retirada as urnas. As bordas, bases, paredes decoradas e apliques dos níveis artificiais da unidade e feição foram encaminhados para a análise, somando o número de 407 fragmentos, cerca de $20 \%$ da amostra do sítio. Ainda, o material coletado no interior das urnas 572, 573 e 685 foram analisados. A urna 685 foi aquela que ofereceu uma amostra relevante, dos 380 fragmentos cerâmicos coletados, 131 considerados diagnósticos foram analisados. Portanto, considerando unidades de escavação, as urnas e seu material de acompanhamento, a amostra do sítio somou 593 peças. 


\begin{tabular}{|c|c|c|c|c|c|c|c|c|c|c|c|}
\hline Conjunto & $\begin{array}{l}\frac{1}{d} \\
\end{array}$ & 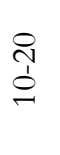 & $\begin{array}{l}\text { ते } \\
\text { }\end{array}$ & $\begin{array}{l}\text { oे } \\
\text { ò } \\
\text { on }\end{array}$ & $\begin{array}{l}\text { in } \\
\text { ô }\end{array}$ & $\begin{array}{l}8 \\
\text { ì } \\
\text { in }\end{array}$ & $\begin{array}{l}\stackrel{0}{\hat{1}} \\
0 \\
0\end{array}$ & $\begin{array}{l}\infty \\
\infty \\
1 \\
1\end{array}$ & 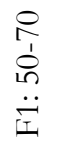 & 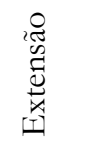 & $\begin{array}{l}\mathscr{L} \\
0 \\
0 \\
\Xi \\
\Xi \\
\Xi\end{array}$ \\
\hline Borda decorada & - & 5 & 30 & 19 & 9 & 1 & - & - & 8 & 2 & 32 \\
\hline Borda s. decor. & - & 3 & 23 & 11 & 2 & 1 & - & - & 2 & 6 & 12 \\
\hline Base & 7 & 5 & 27 & 13 & 2 & 2 & 1 & 2 & 3 & 4 & 24 \\
\hline Parede decorada & 4 & 18 & 101 & 71 & 16 & 6 & 1 & - & 12 & 34 & 54 \\
\hline Parede s. decor. & 41 & 55 & 688 & 204 & 58 & 18 & 5 & 3 & 22 & 124 & 240 \\
\hline Aplique/Alça/Flange & - & 1 & 1 & - & - & - & - & - & - & - & 9 \\
\hline Total & 52 & 87 & 870 & 318 & 87 & 28 & 7 & 5 & 47 & 170 & 380 \\
\hline
\end{tabular}

Tabela 11: Sítio São Miguel do Cacau: triagem da cerâmica

Especificamente na unidade de scavação, o peso da amostra pode indicar concentrações e pisos no depósito (Machado, 2006; Lima, 2008). Cada sítio apresenta uma configuração distinta, Cacoal do Amanã apresenta um peso constante nos níveis 10-20 e entre 40-60 cm, com grande queda na quantidade dos fragmentos cerâmicos no nível 60 70, quando já era possível distinguir claramente o solo estéril e as feições que passaram a concentrar os vestígios de cultura material. No sítio São Miguel, o peso demonstra um único pico de densidade material no pacote arqueológico, entre os 20 e $30 \mathrm{~cm}$ e posterior queda da quantidade de fragmentos, até chegar ao nível estéril aos $80 \mathrm{~cm}$ de profundidade.

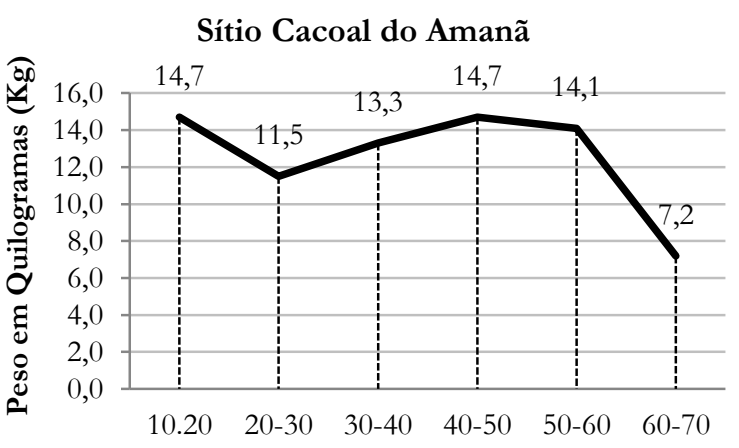

Gráfico 1: Índice de fragmentação por nível artificial.
Sítio São Miguel do Cacau

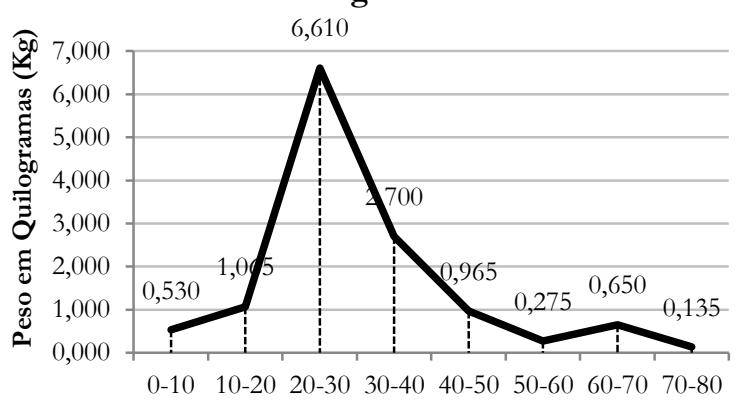

Gráfico2: Índice de fragmentação por nível artificial.

Tendo em vista que ambos os sítios apresentam nos depósitos escavados inversões estratigráficas para a deposição de urnas, não é possível dizer com base nesses números, que as concentrações refletem processos de formação do registro a partir de diferentes episódios de ocupação no sítio Cacoal, e uma única ocupação no Sítio São Miguel, mas eles podem nos ajudar a pensar. 
Os sítios apresentaram um razoável índice de peças remontáveis, as diversas colagens de fragmentos diminuíram os números iniciais da triagem. Também durante a análise quando era perceptível que se tratava de um fragmento de um mesmo vaso já analisado, apenas o número era incorporado aos campos já analisados. Desse modo das unidades de escavação do sítio Cacoal, o número de fragmentos de fato analisado foi de 1.072 (níveis artificiais) e 101 (feições), é a partir deste $n$ que tabelas e gráficos de frequência das técnicas de manufatura, acabamento de superfície e decoração foram organizados. Já no sítio São Miguel o $n$ foi 322 somando fragmentos dos níveis artificiais e feição. A opção por não diferenciar os materiais é devido a minha revisão que a estrutura tratada diferencialmente em campo não se trata de fato de uma estrutura distinta do restante da unidade, como exposto anteriormente no capítulo 3.

\subsection{Sítio Cocoal do Amanã}

\section{Pastase e queimas}

$\mathrm{Na}$ Amazônia central é comum a presença de dois antiplásticos na composição das pastas, o cauixi (Metania kiliani) e o caraipé (Licania spp), além dos minerais que naturalmente compõe as argilas. O primeiro é de origem animal, uma esponja que incrusta folhas ou galhos na vegetação de várzea sazonalmente inundada. Há informações etnográficas do uso intencional dessas esponjas entre alguns grupos indígenas, e relatos de artesãs na própria RDS Amanã sobre seu uso corriqueiro (Menegassi, 2009:60). Entretanto, alguns autores destacam que a presença desse elemento, não significa necessariamente sua adição, já que o cauixi pode ser encontrado nas fontes de argila às margens de lagos e rios (Moraes, 2013; Tamanaha, 2012).

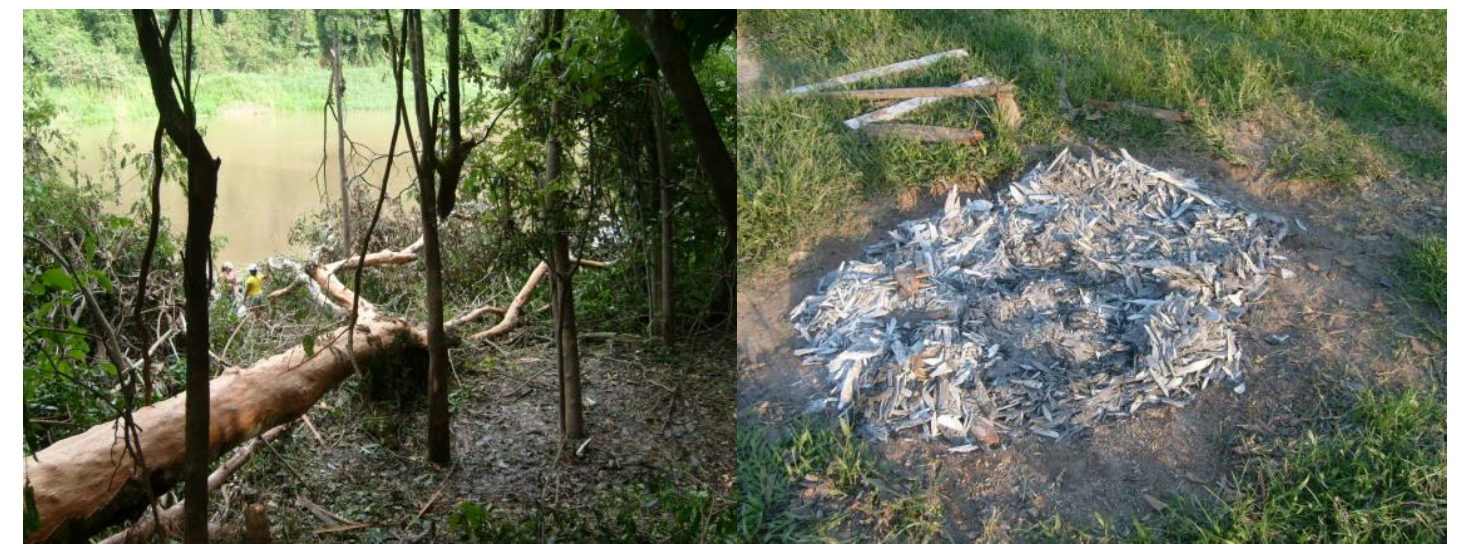

Figura 33: Imagens da derruba do caraipé verdadeira e queima das cascas por oleiras da comunidade Nova Olinda, RDS Amanã. Fotos cedidas por Juliana Menegassi. 
O caraipé é um termo geral dado às cascas de árvores ricas em sílica, que passam por um processo de derruba e queima e é amplamente encontrado em cerâmicas arqueológicas e contemporâneas. Na RDS Amanã um diagnóstico para avaliar a sustentabilidade do uso desse recurso madeireiro indicou locais e distancias percorridas para a obtenção de indivíduos para derruba, estimou a quantidade de cinzas e produção de vasilhames, além de identificar que há pelo menos três diferentes espécies usadas pelas oleiras, o caraipé verdadeiro (ou da terra firme ou da casca grossa) e o cariperana (ou caraipé da várzea ou casca fina) e o caraipé de peixe (encontrado nos igapós, restinga baixa) (Menegassi, 2009:72).

As oleiras de Amanã destacam diferenças entre o barro retirado da várzea e o da terra firme. De acordo com elas, o primeiro tem mais "liga" e é consideravelmente melhor que o da terra firme, que precisa de mais caraipé para ser temperado e exige que a construção dos vasos seja feita por partes, com intervalos para secagem (Op cit: 68).

As fontes ou barreiros, como são chamados pelas oleiras, estão sempre perto das próprias comunidades localizadas nos paranãs de acesso ao lago Amanã, mas em ambiente de várzea. Essa mesma região foi citada por oleiras de comunidades da cabeceira do lago (Boa Esperança e Bom Jesus do Baré) como locais de retirada das bolas de argila.

No sítio Cacoal foi identificado cinco principais antiplásticos que podem ser considerados como básicos: caraipé, cauixi, minerais (grãos de quartzo e hematita), nódulos de argila e carvão. Com exceção de dois fragmentos que apresentaram somente quartzo, esses aditivos foram observados sempre associados formando 32 misturas diferentes considerando as proporções dos antiplásticos identificados (Anexo 4). Em todos os níveis artificiais há uma variação muito expressiva dessas misturas, embora algumas de baixíssima relevância, como no caso de cauixi, caraipé e nódulos de argila.

Sem o objetivo de demonstrar uma uniformidade do uso desses aditivos, mas no intuito de ilustrar melhor as frequências em que ocorrem, essas 32 misturas foram agrupadas em três categorias, considerando a presença e associação dos antiplásticos de origem animal e vegetal. No gráfico 3, é possível ver claramente que até os $40 \mathrm{~cm}$ de profundidade, o caraipé é mais comum, seja associado a minerais e ao cauxi. A partir dos $40 \mathrm{~cm}$, há uma inversão, passando o cauixi a ser predominante. Em todo caso, a presença conjunta dos dois antiplásticos é significativa em todos os níveis artificiais, e nos níveis mais profundos, é relativamente mais expressiva. Nas feições, o cauixi é predominante, havendo na verdade pouca variação no uso de antiplásticos, apenas a F1 apresentou caraipé como principal aditivo. 


\section{Frequência de antiplásticos}

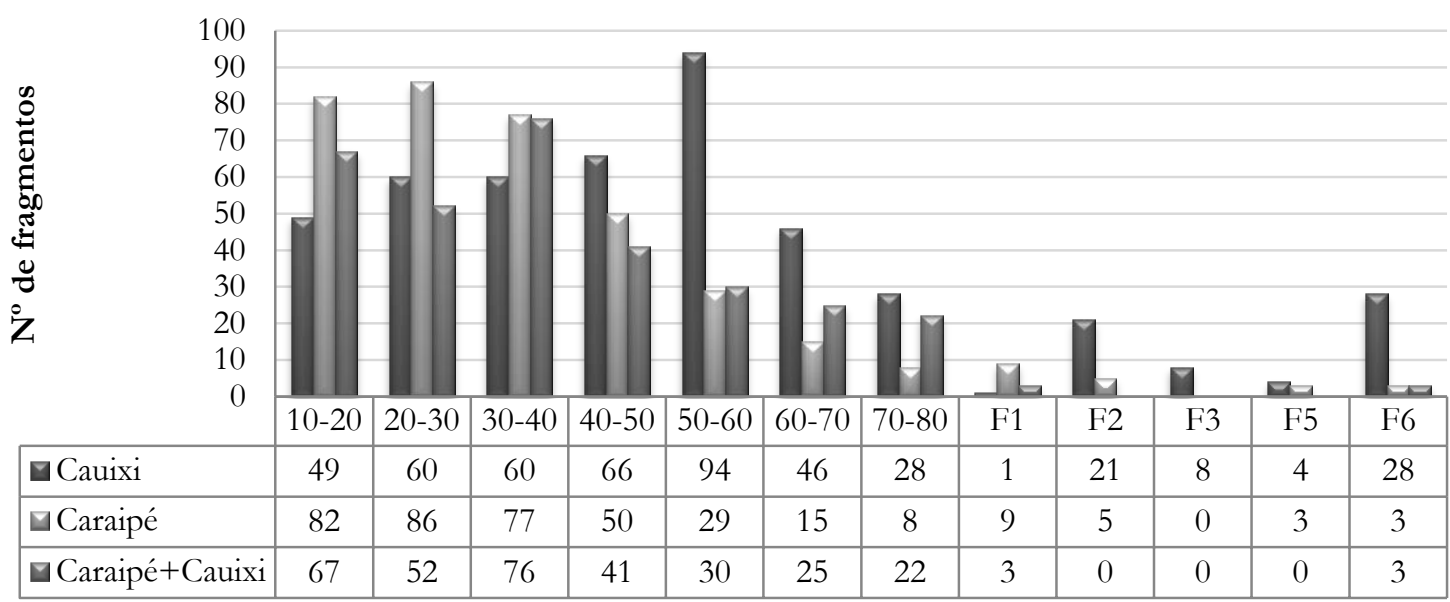

Gráfico 3: Frequencia de antiplásticos (agrupados) observados na amsotra do sítio Cacoal do Amanã

As pastas apresentam por vezes uma grande quantidade de antiplásticos diferentes, em algumas peças a presença de nódulos de argila, visíveis em análise macroscópica (Figura 36 a). Em contrapartida naquelas em que o cauixi é predominante, geralmente as pastas são mais uniformes, compactas, mais bem queimadas e menos friáveis. Embora comum o uso do caraipé em todo pacote arqueológico, ele varia sendo por vezes adicionado abundantemente, de tal forma que as partículas podem ser vistas a olho nu, ou sendo possível ver na superfície do fragmento o negativo de partículas de caraipé (Figura 36 b).

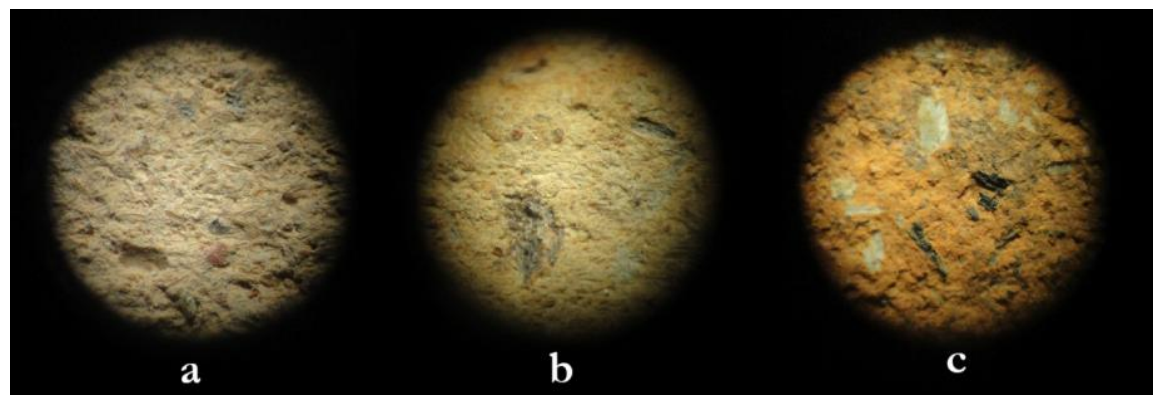

Figura 34: Exemplos de antiplásticos observados na lupa com aumento de 60x. a) cauixi e minerais; b) cauixi e caraipé; c) caraipé e carvão

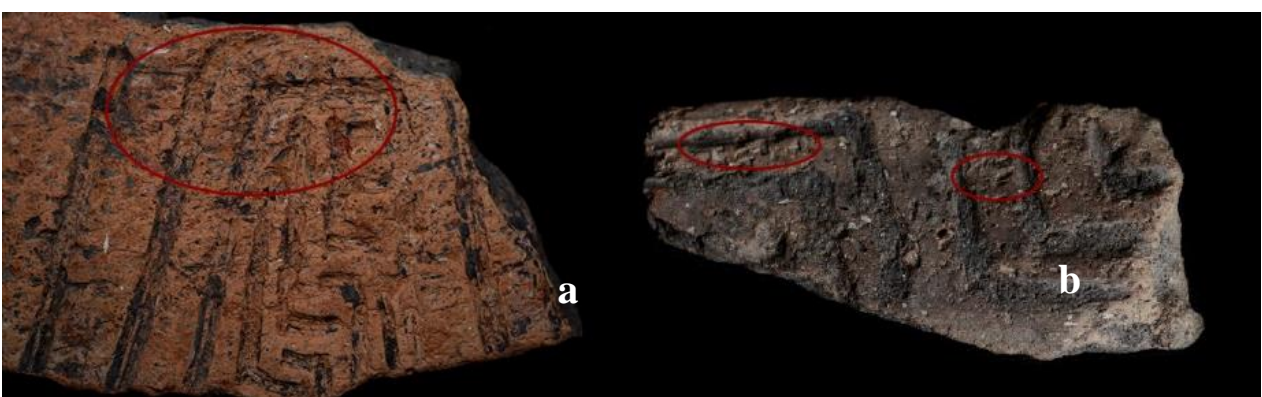

Figura 35: Diferentes usos do caraipé. 
Nos fragmentos arqueológicos a textura e cor da cerâmica nos indicam se a queima foi realizada com maior ou menor presença de oxigênio, o que determina a oxidação ou redução da pasta, ou ainda combinações dos dois processos (Chmyz, 1966:18).

\begin{tabular}{|c|c|c|c|c|c|c|c|c|c|c|c|c|c|c|}
\hline Níveis & & & & & & & & & & & & & \multicolumn{2}{|c|}{ Total } \\
\hline $\begin{array}{l}\text { Tipos } \\
\text { de queima }\end{array}$ & 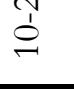 & ֻे & $\stackrel{1}{1}$ & 1) & $\begin{array}{l}1 \\
\stackrel{1}{1}\end{array}$ & d & $\stackrel{1}{\infty}$ & $\vec{I}$ & $\stackrel{N}{I}$ & $\underline{m}$ & 望 & 厌 & $n$ & $\%$ \\
\hline Oxidante & 60 & 69 & 98 & 67 & 79 & 37 & 34 & 4 & 15 & 7 & 3 & 23 & 496 & $42,69 \%$ \\
\hline Redutora & 101 & 102 & 86 & 71 & 51 & 31 & 19 & 6 & 9 & 1 & 4 & 15 & 496 & $42,69 \%$ \\
\hline Ox. Int./red ext & 2 & - & 1 & - & - & - & - & 1 & - & - & - & 1 & 5 & $0,43 \%$ \\
\hline Red. int/Ox ext & 8 & 4 & - & 2 & 1 & 2 & 1 & - & 1 & - & - & - & 19 & $1,64 \%$ \\
\hline Núcleo Redutor & 23 & 17 & 23 & 17 & 19 & 16 & 3 & - & 2 & - & - & 2 & 122 & $10,50 \%$ \\
\hline Não idntificado & 3 & 4 & 4 & 3 & 4 & 1 & 1 & 4 & - & - & - & - & 24 & $2,07 \%$ \\
\hline Total & 197 & 196 & 212 & 160 & 154 & 87 & 58 & 15 & 27 & 8 & 7 & 41 & 1162 & $100 \%$ \\
\hline
\end{tabular}

Tabela 12: Frequência dos tipos de queima por níveis artificiais e feições.

Nos tipos de queima observados houve um equilíbrio entre queima oxidante e completa e queima incompleta (redutora), ambas observadas em 85,37\% da amostra. Peças apresentando o núcleo redutor, somam $10,50 \%$ e a presença em um único fragmento dos dois tipos de queima foi inexpressiva, observada em cerca de $2 \%$ da amostra, sendo a queima oxidante externa e redutora interna a mais relevante. Esses números, apesar de gerais, indicam um pouco sobre o ambiente de queima, talvez bastante variado, realizada em ambiente aberto, onde é difícil controlar a temperatura. Contudo quando consideramos as proporções em que ocorrem nos níveis artificiais, a queima redutora completa ou parcial é presente em 62,9\% da amostra no nível 10-20 (124 das 197 peças analisada), aos 20-30 cm, em 60,7\% (119 das 196 peças). Entre 30 e 70 cm, observa-se que os tipos de queima tornam-se mais equilibrados, com uma leve tendência a queima oxidante, já no último nível artificial, é este o tipo de queima predominante, ocorrendo em 58,6 \% das peças analisadas ( $\mathrm{n}=34)$. Por fim, há uma relação entre o tipo de queima e a parte do vaso analisada, as bases apresentam uma leve tendência a terem queima oxidante, e as bordas e paredes, queimas variadas. Mas os apliques, flanges labiais e mesiais, apresentam predominantemente queima incompleta ou com núcleo redutor. Não por acaso essas são partes dos vasos mais espessas, geralmente com sobreposição e justaposição de roletes e modelados.

A cor da pasta é resultado de diferentes fatores que envolvem a composição da argila, os antiplásticos presentes, o ambiente de queima e tratamentos de superfície. Muitas vezes as superfícies internas apresentam colorações diferentes daquela observada externamente, ou ainda variações bastante significativas em um mesmo vaso (Figura 23). Também foi comum observar marcas e manchas enegrecidas nas superfícies externas das 
cerâmicas (Figura 37). Moraes (2013:38) destaca que embora os materiais da fase Axanim e Paredão por ele analisados não fossem queimados em temperaturas altas o suficiente para a oxidação completa das pastas, essas machas e o grande número de feições registradas em campo, o levam a sugerir que vasos podem ter sidos queimados em fogueiras dentro de buracos.

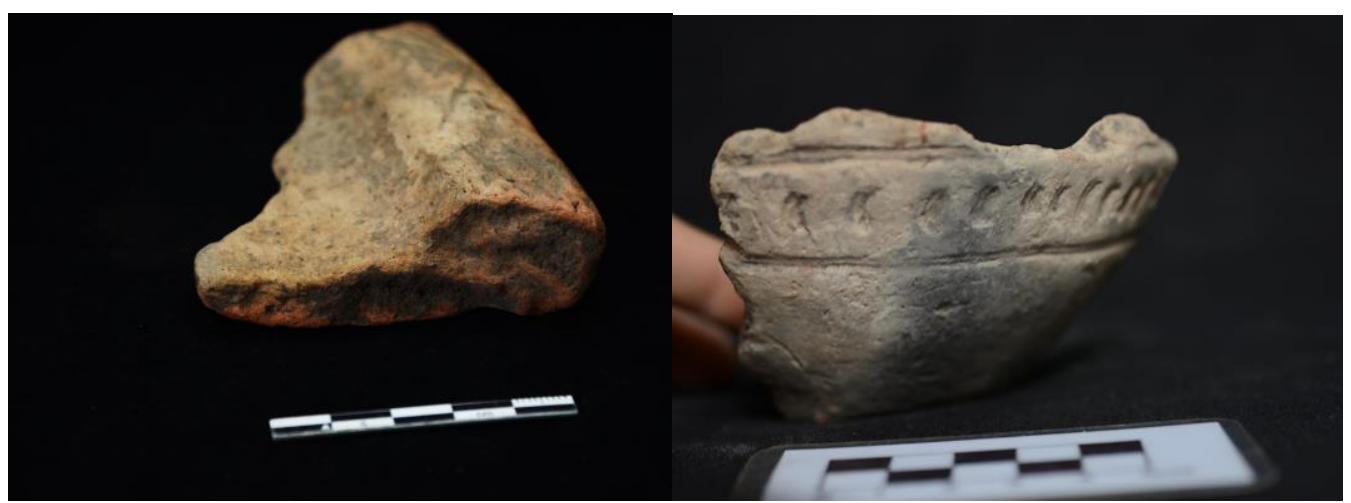

Figura 36: Fragmento de assador com variação da cor da pasta. A lado perfil de um vaso com marca enegrecida resultante do processo de queima.

De todo modo como a cor da pasta é uma variável bastante subjetiva e depende de diversos fatores e condições, com um amplo leque de combinações, a tabela ao lado sintetiza as colorações observadas.

\begin{tabular}{|c|c|c|c|c|}
\hline Cor da pasta & $\begin{array}{c}\mathrm{n} \\
\text { níveis }\end{array}$ & $\%$ & $\begin{array}{c}\mathrm{n} \\
\text { feições }\end{array}$ & $\%$ \\
\hline Cinza / branca & 83 & $7,9 \%$ & 11 & $12,0 \%$ \\
\hline Laranja & 290 & $27,7 \%$ & 28 & $30,4 \%$ \\
\hline Marrom & 353 & $33,7 \%$ & 22 & $23,9 \%$ \\
\hline Preta & 50 & $4,8 \%$ & 3 & $3,3 \%$ \\
\hline Laranja forte & 157 & $15,0 \%$ & 23 & $25,0 \%$ \\
\hline Rosa-avermelhada & 115 & $11,0 \%$ & 5 & $5,4 \%$ \\
\hline Total & 1048 & & 92 & \\
\hline
\end{tabular}

Em termos gerais, as superfícies apresentam coloração alaranjada e marrom, normalmente quando apresentam um tom mais forte de laranja são peças que com queima oxidante (110 dos 157 fragmentos). Chama atenção também que parte significativa da amostra apresenta tons rosados e avermelhados, o que possivelmente se relaciona com a quantidade de minerais como a hematita (e talvez limonita, mas apenas análises arqueométricas podem confirmar) nas fontes de argila.

Por fim, seja nas feições ou nos níveis artificiais, observou-se a superfície interna de fragmentos escurecida. Essas características podem se referir a distintos tratamentos de superfície que não consegui identificar e ou a marcas de uso, como discutirei mais a frente. 
O tratamento de superfície mais observado foi o alisamento em $83,8 \%$ das peças, seguido do polimento (5,2\%) e escovado (3,5\%). Outros acabamentos como enegrecimento e possíveis aplicações de barbotina, correspondem a menos de $1 \%$ do total das peças. Cerca de $6,8 \%$ da amostra não possibilitou observar ou inferir sobre o tratamento aplicado (Tabela 11). Parti do pressuposto que se a peça foi decorada lhe foi aplicado algum tratamento, sendo o mais simples o alisamento, dessa maneira a alta frequência desse tipo de tratamento se deve a observação de sua presença em uma de suas superfícies.

\begin{tabular}{|c|c|c|c|c|c|c|c|c|c|c|c|c|c|c|}
\hline \multirow[b]{2}{*}{ Tratamento Niveis } & \multirow[b]{2}{*}{ 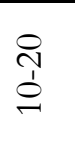 } & \multirow[b]{2}{*}{ ते } & \multirow{2}{*}{$\begin{array}{l}\text { q } \\
\text { ò } \\
\text { cे }\end{array}$} & \multirow[b]{2}{*}{$\begin{array}{l}\text { ڤn } \\
\text { ôे }\end{array}$} & \multirow[b]{2}{*}{$\begin{array}{l}8 \\
0 \\
i \\
i n\end{array}$} & \multirow[b]{2}{*}{$\begin{array}{l}0 \\
1 \\
0 \\
0\end{array}$} & \multirow[b]{2}{*}{$\begin{array}{l}8 \\
\vdots \\
\infty\end{array}$} & \multirow[b]{2}{*}{$\bar{I}$} & \multirow[b]{2}{*}{ I } & \multirow[b]{2}{*}{ 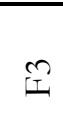 } & \multirow[b]{2}{*}{$\stackrel{2}{L}$} & \multirow[b]{2}{*}{ 层 } & \multicolumn{2}{|c|}{ Total } \\
\hline & & & & & & & & & & & & & $\mathrm{n}$ & $\%$ \\
\hline Alisamento & 131 & 153 & 177 & 147 & 142 & 84 & 54 & 8 & 25 & 7 & 5 & 38 & 971 & $83,8 \%$ \\
\hline Polimento & 7 & 20 & 17 & 4 & 11 & - & 2 & - & - & - & - & - & 61 & $5,2 \%$ \\
\hline Escovado & 2 & 10 & 14 & 8 & 1 & 2 & & 3 & - & - & 1 & - & 41 & $3,5 \%$ \\
\hline Enegrecimento & - & 5 & - & - & - & - & - & - & - & - & - & - & 5 & $0,4 \%$ \\
\hline Barbotina & - & 1 & - & - & - & - & - & - & - & - & - & - & 1 & $0,09 \%$ \\
\hline Não Identificado & 54 & 7 & 6 & 1 & - & 1 & 2 & 1 & 2 & 1 & 1 & 3 & 79 & $6,8 \%$ \\
\hline Tota & 194 & 196 & 214 & 160 & 154 & 87 & 58 & 12 & 27 & 8 & 7 & 41 & 1158 & $100 \%$ \\
\hline
\end{tabular}

Tabela 13: Frequencia dos diferentes tipos de tratamento de superfície.

O escovado foi observado sempre na superfície externa do vaso (Figura 38c), já o enegrecimento aqui neste caso, foi considerado quando possível observar uma camada sobre a superfície, sua ocorrência foi pontual, restringindo-se ao nível 20-30 (Figura 38a). É bem provável que o polimento tenha sido uma técnica mais frequente na produção desses artefatos, mas o grau de preservação dos fragmentos não permitiu sua observação.

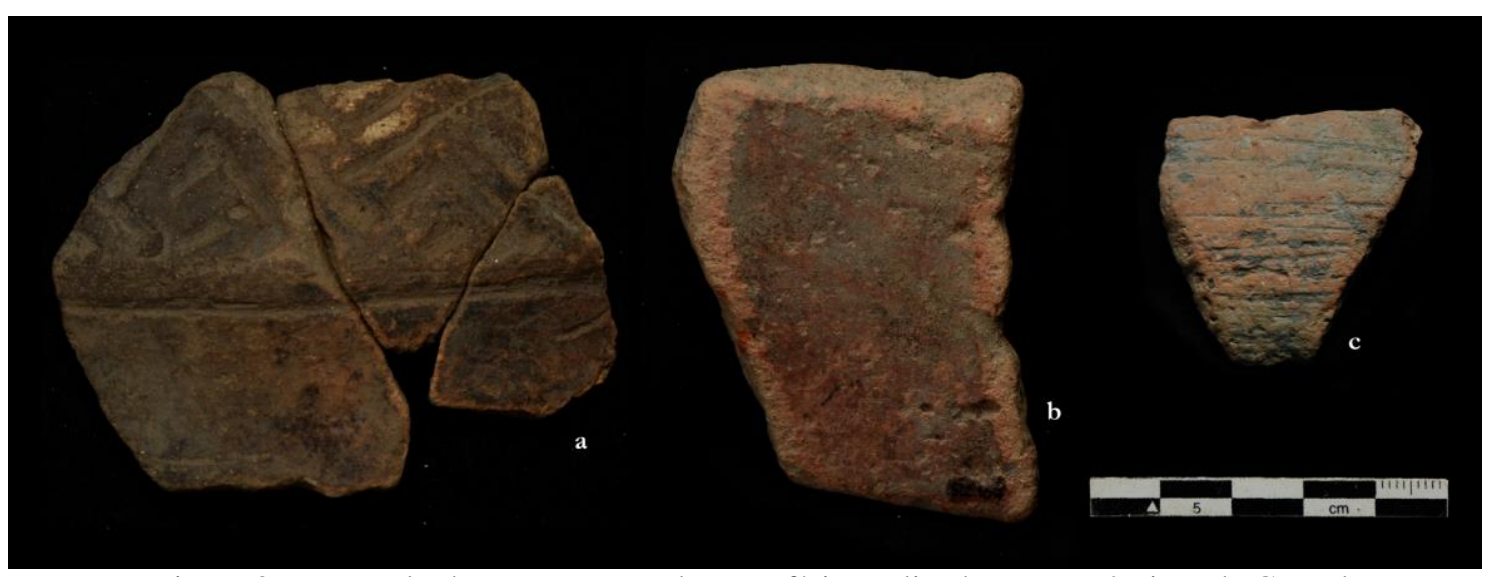

Figura 37: Exemplo dos tratamentos de superfícies aplicados nas cerâmicas de Cacaol. 
Em geral as superfícies dos fragmentos se apresentavam muito erodidas, principalmente nos níveis mais superficiais (Figura 39). Esse argumento pode ser reforçado com as informações sobre a decoração dos vasos. Em um primeiro momento a impressão é que as técnicas decorativas mais aplicadas são as plásticas, no entanto através da lupa foi possível observar vestígios de pintura ou engobo imperceptíveis em análises macroscópicas, aumentando consideravelmente o número de peças com aplicação de decoração com técnicas pintadas.
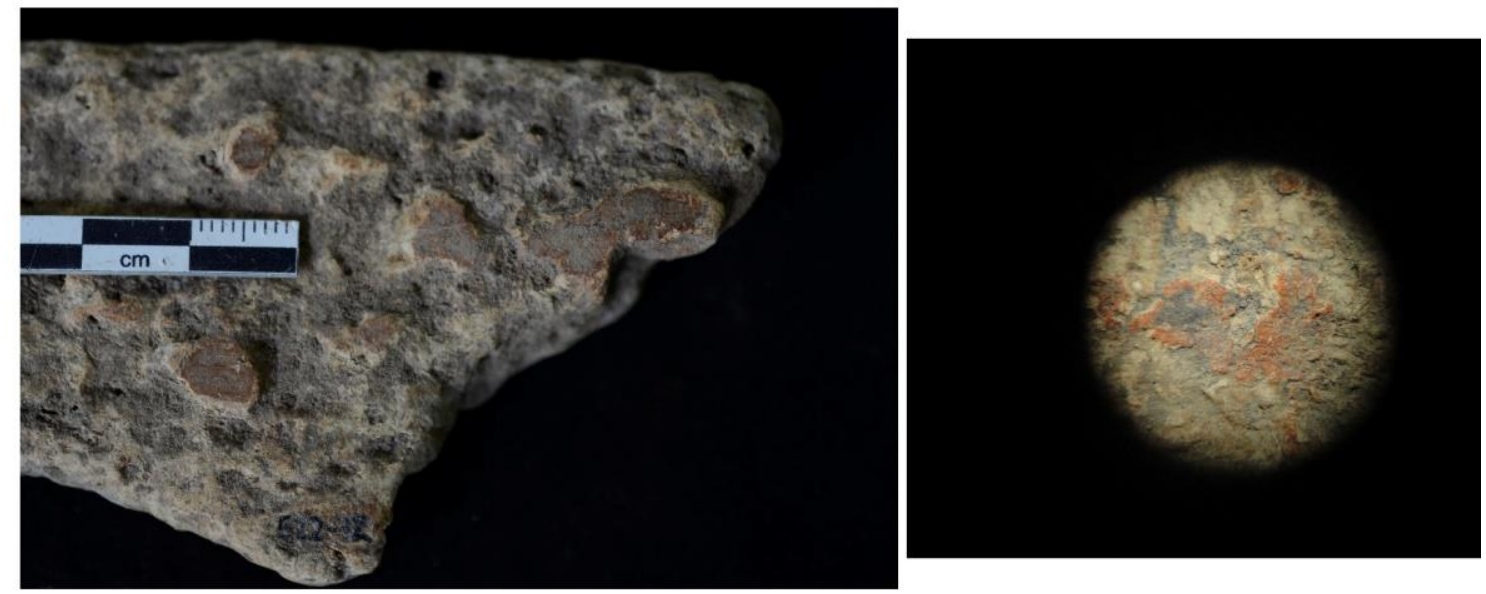

Figura 38: Fragmento proveniente do nível $10-20 \mathrm{~cm}$, ao lado fotografia a partir da lupa com aumento de $40 \mathrm{x}$ de vestígios de engobo e pintura, visiveis praticamente apenas nas análises microscópicas.

\section{Morfologias}

Variabilidade morfológica foi observada a partir dos fragmentos de bordas e lábios oferecendo um retrato geral da amostra. $\mathrm{Na}$ tabela do anexo 5 , estão sistematizadas essas informações e como é possível perceber, há uma flutuação nos números totais de peças. Isso ocorre, pois para inferir o contorno do vaso as bordas, flanges e paredes com pontos de inflexão foram considerados. Das 657 peças analisadas que permitiam essa inferência, $53,1 \%$ (349) são vasos de contorno simples, 10,2\% (67) apresentam contorno composto e apenas 4,3\% (28) são fragmentos de vasos de contorno complexo, observados em maior número entre os 20 e $40 \mathrm{~cm}$ de profundidade.

Em relação à forma em si, quase metade da amostra é composta de vasos irrestritivos (45,5\% ou 279 peças), já vasos que poderiam ser restritivos somaram $15,8 \%$ da amostra, seguido dos vasos verticiais com 12,6\%. Mais de $25 \%$ das bordas analisadas não permitiram observar esse atributo. Quando levamos em conta a distribuição desses números pelo pacote arqueológico, há uma tendência de vasos restritivos serem mais frequentes nos níveis superficiais, já nos níveis profundos, especificamente no 80-90, praticamente $80 \%$ das bordas nos indicam vasos irrestritivos. 


\section{Forma do Vaso}

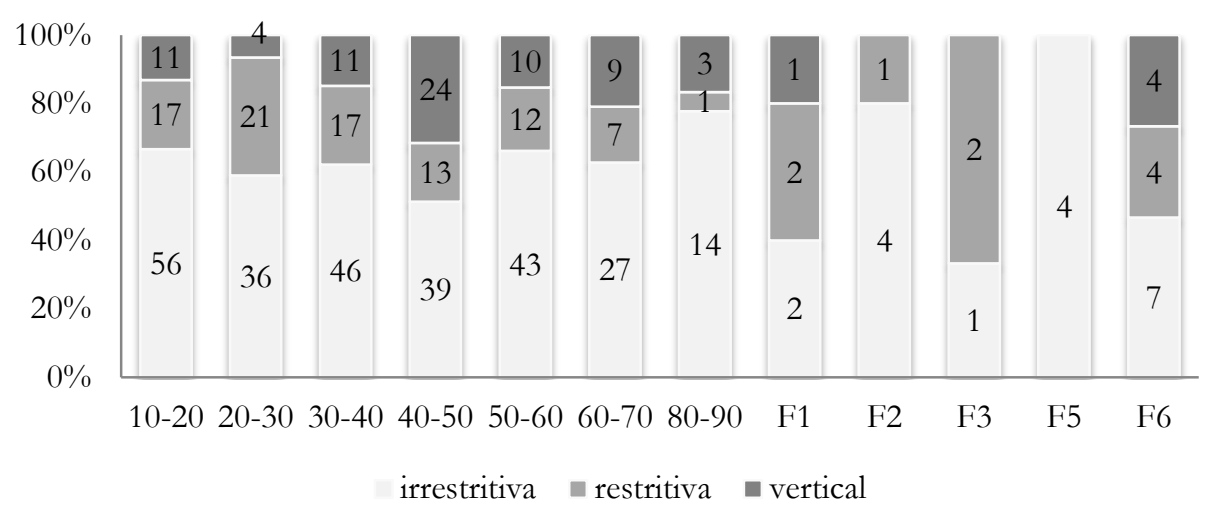

Gráfico 4: Frequencia de formas de vasos observadas nos níveis artificiais e feições.

Bordas e lábios: Bordas de formato reto foram as mais comuns $(41 \%, 8)$, as contraídas representam $26,8 \%$, e expandidas $16,1 \%$ e reforçadas $12 \%$, sendo mais relevantes aquelas reforçadas externamente. Os lábios variaram principalmente entre três formas, os arredondados (48,2\%), planos $(32,5 \%)$ e afilados (17,3\%), sendo mais raro o formato bisel (2\%). Considerando apenas os lábios e não flanges labiais, receberam acabamento 108 peças. A técnica de retirada da argila formando um lábio serrilhado foi a mais frequente, presente em 29 peças (26,9\%) e bastante comum no nível 30-40 (Figura 40). O segundo acabamento mais frequente foi aplicação de engobo, geralmente observado em toda a superfície do fragmento $(19,4 \%$, i.e. 21 peças). O modelado foi a terceira forma de acabamento mais comum, em 17 peças (15,7\%), seguida pelas técnicas de incisão e excisão, ambas observadas em 10 lábios. Ainda foram registradas outras técnicas plásticas: ungulado, cortado, acanalado, digitado e ponteado, que juntos foram aplicados em 14,8\% dos lábios. Por fim, aplicação de pintura foi registrada nos lábios, mas apenas até os $40 \mathrm{~cm}$ de profundidade do depósito (5 peças).

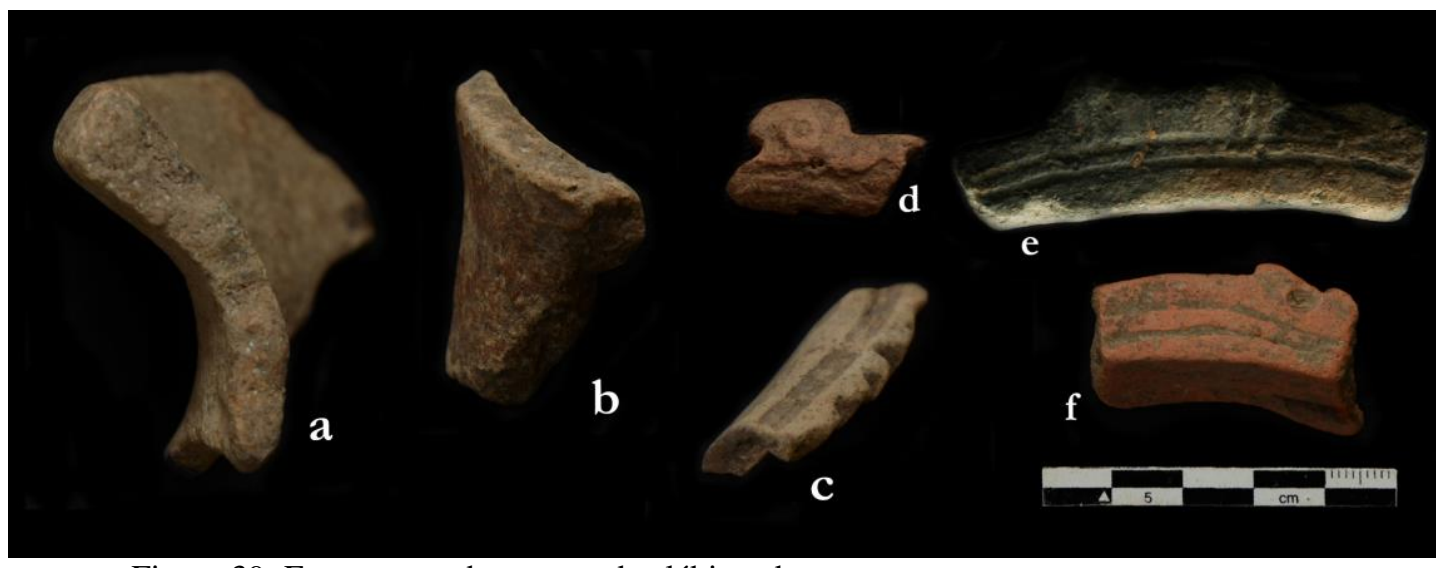

Figura 39: Formas e acabamentos dos lábios, destaque para a peça c, que apresenta serrilhado, técnica bastante frequente no sitio Cacoal 
Bases: As bases analisadas somaram 116 peças, das quais 91 são planas, 8 convexas, 1 com pedestal, 5 côncavas e 11 são planas com marcas de folha na face externa. Não são representativas diferenças de frequência se distribuídas pelos níveis artificiais. De todas as bases, 61 apresentaram curvatura que permitia mensurar o diâmetro em $\mathrm{cm}$ com auxílio de um ábaco. $\mathrm{Na}$ tabela abaixo as informações foram agrupadas em quatro intervalos de medida.

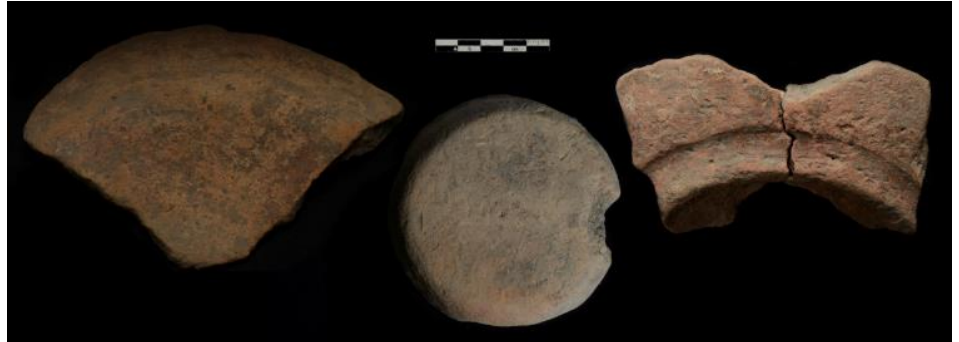

Figura 40: Diferentes tipos de base ientificadas no sítio Cacoal.

\begin{tabular}{|c|c|}
\hline Tamanho & $\mathrm{n}$ \\
\hline $\begin{array}{l}\text { Pequena } \\
(4 \text { a } 10 \mathrm{~cm})\end{array}$ & 22 \\
\hline $\begin{array}{l}\text { Média } \\
(11 \text { a } 20 \mathrm{~cm})\end{array}$ & 31 \\
\hline $\begin{array}{l}\text { Grande } \\
(22 \text { a } 40 \mathrm{~cm})\end{array}$ & 4 \\
\hline Muito Grande & 4 \\
\hline
\end{tabular}

Os conjuntos morfológicos foram definidos com base na cassificação de Shepard (1956), considerando a restrição ou não da boca do vaso e contorno da forma, a partir do número de pontos de inflexão. Abaixo estão apresentadas as descrições das caracterisitcas morfológicas e reconstiuições gráficas.

Conjunto 1: Morfologias irrestritivas de contorno simples

\begin{tabular}{|c|c|}
\hline & $\begin{array}{l}\text { Forma } 1 \text { - Forma semi-esférica. Cuia. Borda direta ou } \\
\text { levemente extrovertida. As formas das bordas variam } \\
\text { bastante, podem ser retas, expandidas, contraídas e } \\
\text { reforçadas. Lábios são em maioria, planos, mas podem } \\
\text { ser arredondados e afilados. Nos casos das bordas } \\
\text { expandidas, os lábios quase sempre recebem decoração } \\
\text { plástica: incisão simples e duplas e acanalados. Base } \\
\text { plana. Diâmetro varia entre } 10 \text { e } 24 \mathrm{~cm} \text {. }\end{array}$ \\
\hline & $\begin{array}{l}\text { Forma } 2 \text { - Forma de calota. Prato com flange. } \\
\text { Apresenta bordas extrovertidas e flanges labiais, } \\
\text { também podem ter reforço interno. Os lábios podem } \\
\text { ser planos e afilados, com acabamento serrilhado. } \\
\text { Praticamente todos apresentam decoração plástica. } \\
\text { Diâmetro varia entre }\end{array}$ \\
\hline & $\begin{array}{l}\text { Forma } 3 \text { - Forma semi-esférica. Prato. As bordas tem } \\
\text { inclinação direta, extrovertida e podem apresentar } \\
\text { extroversão tipo flange. Normalmente são expandidas, } \\
\text { com lábios arredondados, planos, biselados, afilados e } \\
\text { serrilhados. Apresentam muita decoração. Diâmetro } \\
\text { varia entre } 13 \text { e } 30 \mathrm{~cm} \text {, sendo mais comuns medidas } \\
\text { medianas entre } 16 \text { e } 22 \mathrm{~cm} \text {. }\end{array}$ \\
\hline
\end{tabular}



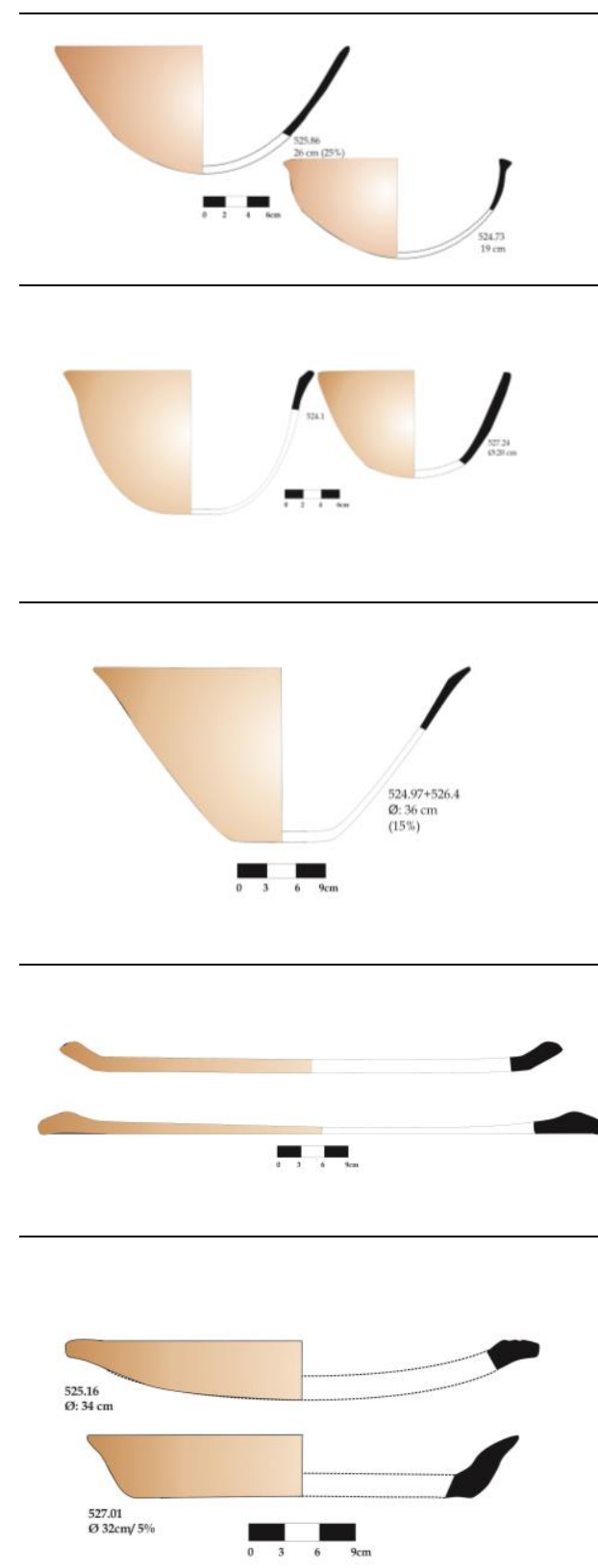

Forma 4 - Forma semi-esférica. Tigelas rasas. Bordas com inclinação direta e levemente extrovertida. As bordas podem ser retas, expandidas, reforçadas externamente e contraídas. Lábios podem ser afilados, arredondados, planos e biselados. Espessura Diâmetro varia entre 18 e $24 \mathrm{~cm}$.

Forma 5 - Forma semi-esférica. Tigela profunda. Bordas de inclinação direta ou extrovertida, com formas retas, contraídas e reforçadas internamente. A espessura varia entre 7 e $13 \mathrm{~cm}$. Os lábios podem ser arredondados, planos e afilados. O diâmetro varia entre 24 e $30 \mathrm{~cm}$.

Forma 6 - Forma profunda com paredes que se abrem com ângulo acentuado. Bordas podem apresentar inclinação direta e extrovertida. Um único caso de extroversão tipo flange foi observado. Bordas podem ser retas, contraídas e expandidas. Os lábios são arredondados e biselados.

Espessura varia entre 8 e $14 \mathrm{~mm}$.

Diâmetro entre 22 e $36 \mathrm{~cm}$.

Forma 7 - Formas rasas de grandes proporções.

Assadores. A espessura varia entre 17 a $35 \mathrm{~mm}$. Podem ter bordas diretas e reforçadas. Lábios são

arredondados. Podem apresentar incisões nas bordas e base com marcas de folha.

Diâmetro: $44-58 \mathrm{~cm}$

Forma 8 - Formas rasas de proporções medianas. Assadores/ "frigideiras". As bordas são diretas ou extrovertidas formando flange labial. A espessura da parede pode atingir $3 \mathrm{~cm}$ e da borda $2 \mathrm{~cm}$. Lábios arredondados ou planos. Foram observados poucos exemplares dessa forma que subdividi em duas. Base plana. Diâmetro: $30-36 \mathrm{~cm}$

\section{Conjunto 2: Morfologias irrestritivas de contorno composto}

Forma 9 - Forma de calota composta. Borda com
inclinação extrovertida com ponto de inflexão
acentuado. Forma rara. Espessura do flange é de $11 \mathrm{~mm}$
e diâmetro inferido de $20 \mathrm{~cm}(8 \%)$.


Conjunto 3: Morfologias restritivas com contorno simples

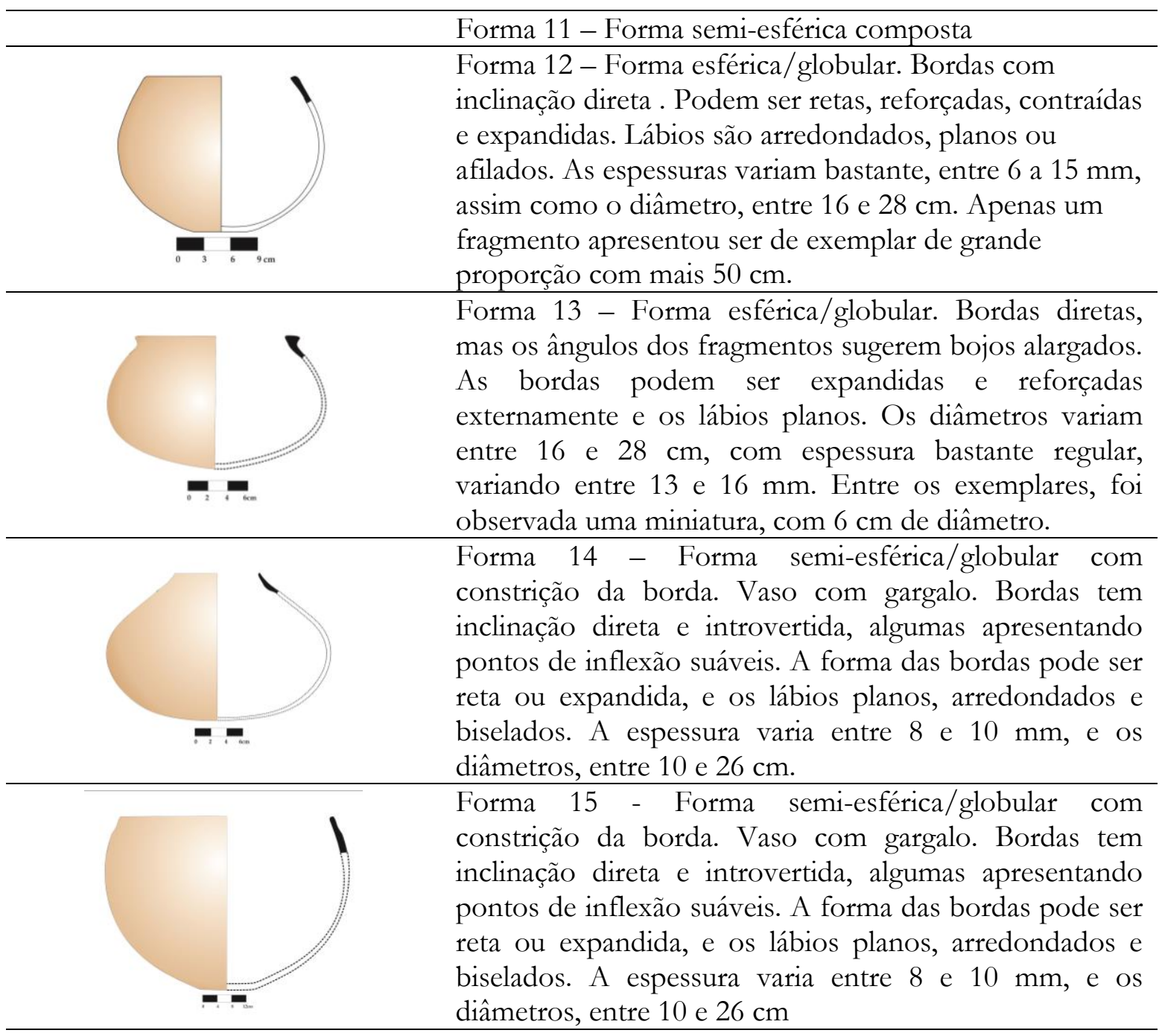

Conjunto 4: Morfologias restritivas com contorno composto

Forma 17 - Forma de calota composta. Apresenta bordas
com inclinação introvertida, com ponto de inflexão
acentuado. O ângulo dos fragmentos sugere vasilhas pouco
profundas. O formato da borda é reto, com lábios
arredondados ou afilados. O diâmetro varia entre 20 e 24
cm.




\begin{tabular}{ll}
\hline & Forma 20 - Forma restrita de contorno composto. As \\
& bordas apresentam inclinação direta, com formato bastante \\
& regular com o reforço externo. O ângulo de projeção dos \\
& fragmentos indica bojos mais alargados, que a forma 19. A \\
& espessura dos lábios é muito regular entre 10 e $12 \mathrm{~mm}$, já o \\
& diâmetro entre 14 e $22 \mathrm{~cm}$. Essa forma foi registrada apenas \\
& entre os níveis 10 e $30 \mathrm{~cm}$. \\
\hline
\end{tabular}

Conjunto 5: Morfologias restritivas com contorno complexo

Forma 21 - Forma restritiva de contorno complexo. Foi observado um único exemplar dessa forma que é semelhante à formas de urnas da fase Manacapuru. Nesse caso, o vaso apresenta em sua borda dois ponto de inflexão. Um deles, formado a partir do reforço externo da borda. O diâmetro inferido foi de $11 \mathrm{~cm}$, a partir de $10 \%$ da circunferência da borda.

Conjunto 6: Morfologias verticais com contorno simples

Forma 22 - Forma vertical contorno composto. Borda
com inclinação direta, mas um ponto inflexão suave faz
o limite entre borda e parede. O ângulo de projeto
sugere parede paralelas. As bordas podem ser
expandidas ou reforçadas externamente. Lábios são
planos ou arredondados. A espessura varia entre 7 e 9
mm, já o diâmetro entre, 10 e $20 \mathrm{~cm}$.

Conjunto 7: Morfologias de contorno complexo

\begin{tabular}{l|l} 
Forma 25 - Vaso inferido graficamente. Não há \\
informações de borda e dimensões. A flange mesial é \\
típica da Tradição Polícroma, com grande expansão da \\
superfície que recebe decoração acanalada e abaixo uma \\
marca de fixação.
\end{tabular}



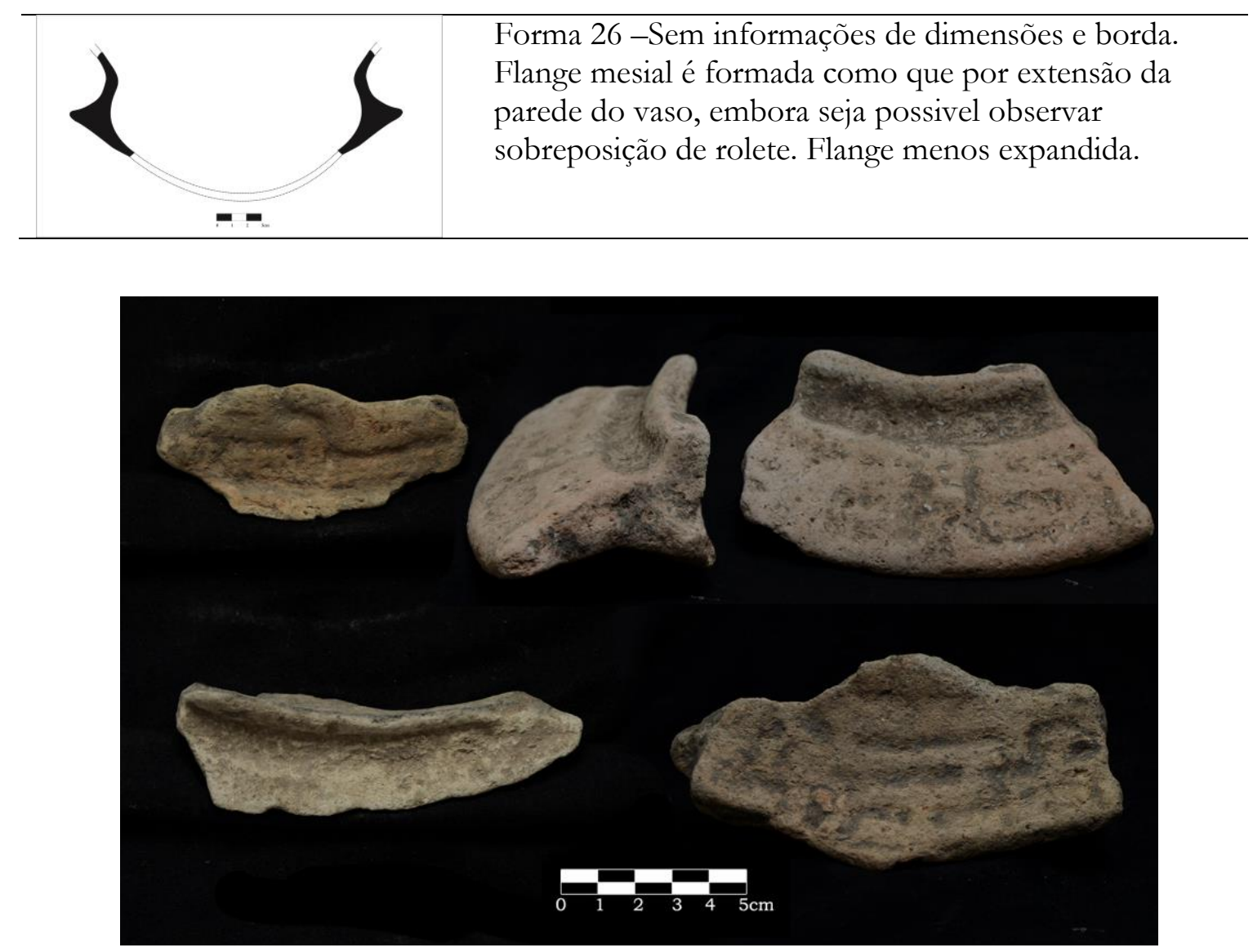

Figura 41: Flanges mesiais - fase Tefé

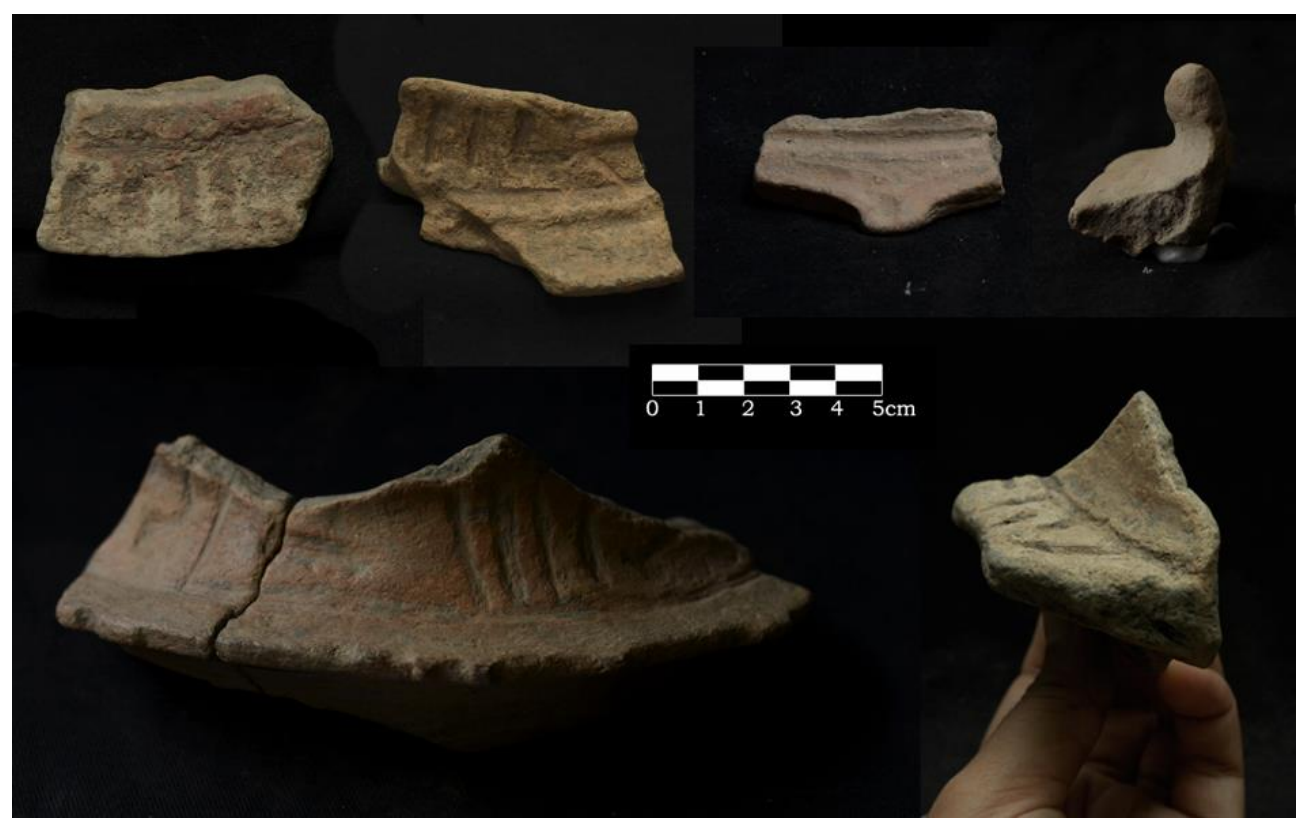

Figura 42: Flanges mesiais - Fase Caiambé

As morfologias de contorno complexo apresentam duas recontituições, pouco seguras já que não foram inferidas com informações das dimensões e formato de borda. No entanto a opção por ilustrá-las serve para distinguir dois tipos de vasos distintos embora o elemento morfológico comum. Lima (2014) em sua análise de materiais da Tradição Pocó-Açutuba e Borda Incisa de sítios do rio Unini, apresenta morfologias 
complexas com flange mesial, corroborando que esse elemento morfológico, apesar de um fóssil guia da Tradição Polícroma, já ocorria em cerâmicas mais antigas. No sítio Cacoal há uma relevante variabilidade no formato de flanges mesiais, algumas de pequenas proproções. $\mathrm{Na}$ figura 41 alguns exemplos que podem ser considerados típicos da Tradição Polícroma, relacionada à fase Tefé, o fragmento à esquerda superior, foi datado em 750 +/$30 \mathrm{BP}$.

Chamo atenção para a identificação de um ralador coletado no nível 50-60 cm. Ele apresenta cauixi como antiplástico principal e $2 \mathrm{~cm}$ de espessura. Não foram identificadas estrias sobre sua superfície. O que é interessante, é que este parece ser o primeiro exemplar encontrado na calha do Amazonas, visto que não há nenhuma referencia de objetos desse tipo em trabalhos anteriores. Raladores são tipicamente definidos como grandes vasos achatados ou ligeiramente curvos com sulcos paralelos profundos impressos na face interior. São
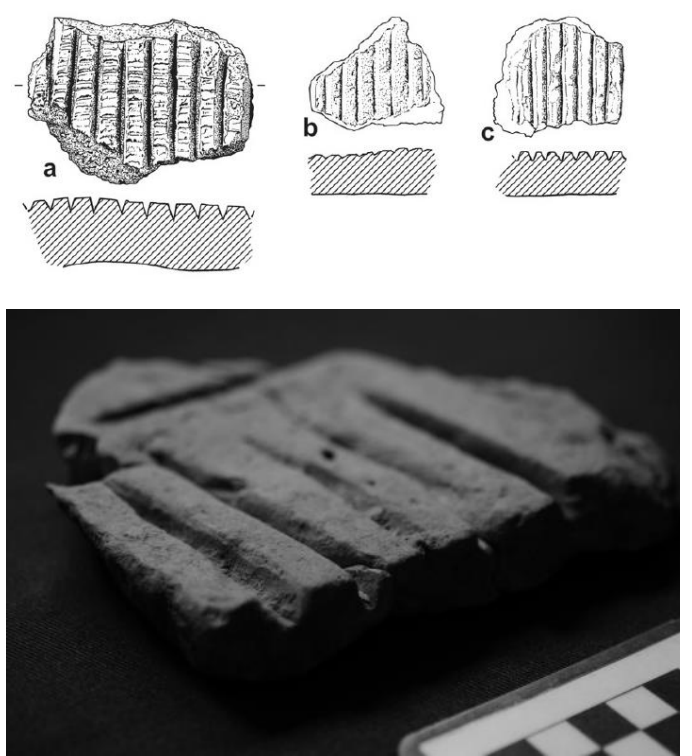

Figura 43: Desenhos de assadores dos contextos arqueológicos da Amazônia boliviana, reproduzidos a partir de Dickau et al, 2011. Abaixo, o fragmento de assador identificado no sítio Cacoal interpretados como instrumentos usados no processamento da mandioca e outros alimentos (Jaimes Bentancourt, 2010; Nordenskiöld, 1913). As análises botânicas de microvestígios recuperados em raladores de contextos de Llamos de mojos na Amazônia boliviana (Figura 29) indicam que embora tenha sido timidamente identificado vestígio de

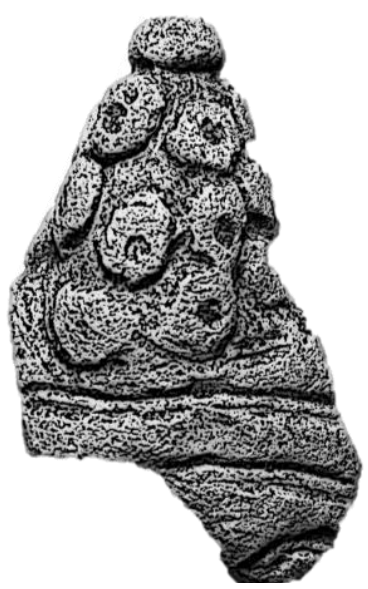
mandioca, o milho foi muito mais frequente nas amostras, além dos raladores naqueles contextos terem provavelmente sido utilizados para processamento de pimentas e palmeiras (Dickau et al, 2011: 12).

No sítio Cacoal a presença de apliques e apêndices é bastante rara, ocorrendo apenas 4 em todo pacote escavado, todas elas são figuras abstratas e maciças, além de 
diferentes formatos de fusos e cocorrência de estuetas zoomorfa, antromomorfa e abstrada.

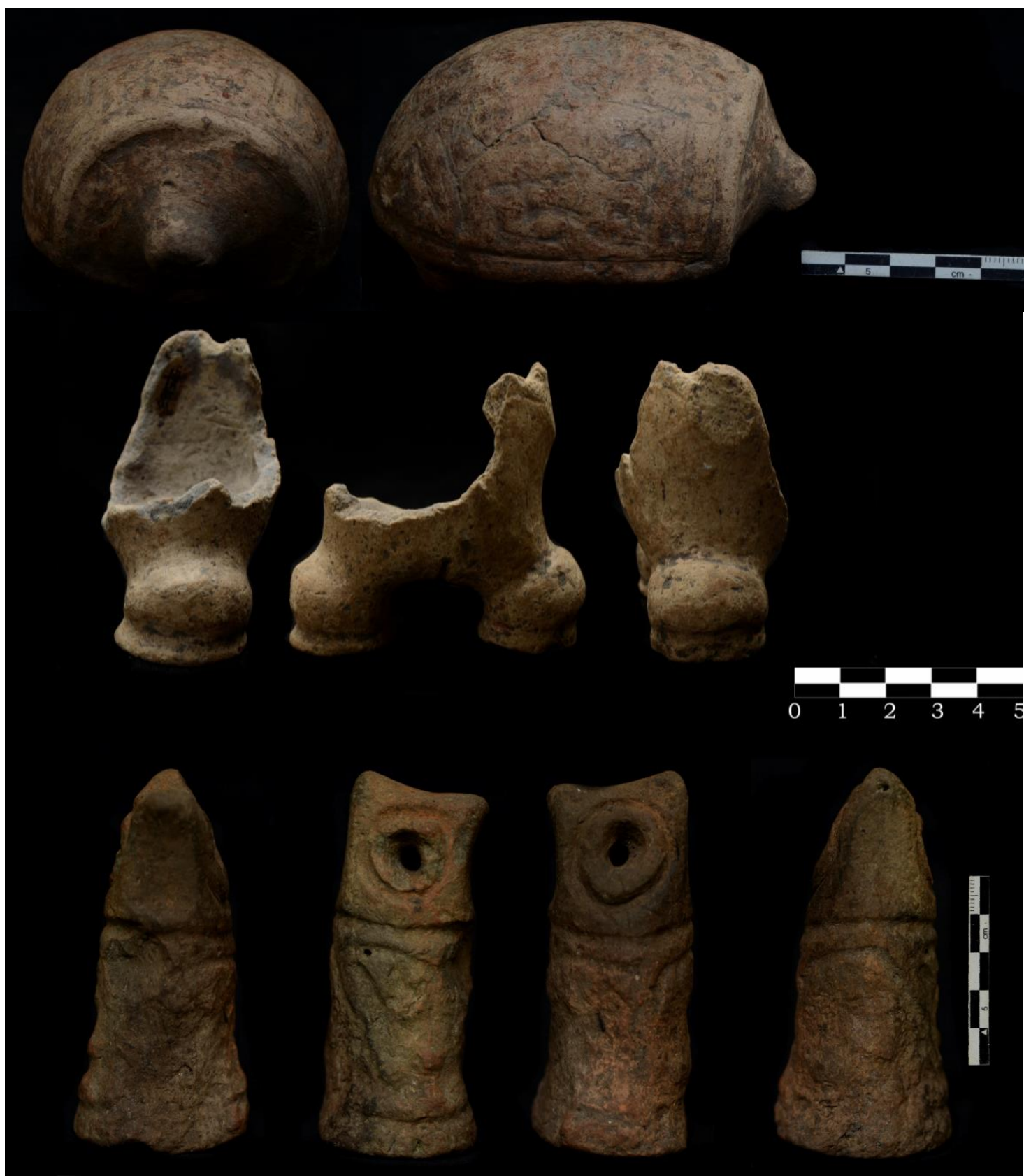

Figura 44: Prancha com estauetas do sítio Cacoal.

Decoração: técnicas, preferências e repertório gráfico

As bordas, sejam elas extrovertidas ou diretas, são os locais privilegiados para a decoração, mas paredes externas (próximo à borda), e em menor quantidade, os lábios, também foram campos decorativos. Na tabela 12 está sistematizada a ocorrência das técnicas decorativas considerando níveis artificiais e feições. Entre as técnicas pintadas, o engobo branco é o mais frequente, presente em $53,4 \%$ das peças e comum em todo pacote 
arqueológico. O engobo vermelho é a segunda técnica mais utilizada, registrado em 33,3\% da amostra, mas há uma concentração de sua ocorrência até os $20 \mathrm{~cm}$ de profundidade, das 166 peças em que ele foi observado, 123 são provenientes do nível 10-20, já aos 30 cm esse número cai para 30 peças e nos restante no pacote arqueológico, sua ocorrência sozinha é bastante rara. A bicromia, o vermelho e muito raramente o vinho (ocorreu em 3 peças) aplicados sobre o engobo branco, tem uma ocorrência relativamente constante até $50 \mathrm{~cm}$ de profundidade.

\begin{tabular}{|c|c|c|c|c|c|c|c|c|c|c|c|c|c|c|}
\hline \multirow[t]{2}{*}{ Técnicas } & \multirow{2}{*}{$\begin{array}{l}\stackrel{\vartheta}{1} \\
\stackrel{\sigma}{\sigma}\end{array}$} & \multirow{2}{*}{$\begin{array}{l}\text { के } \\
\text { ôे }\end{array}$} & \multirow{2}{*}{$\begin{array}{l}\text { P } \\
\text { 1े } \\
\text { in }\end{array}$} & \multirow{2}{*}{$\begin{array}{l}\text { in } \\
\text { ó } \\
\text { fon }\end{array}$} & \multirow{2}{*}{$\begin{array}{l}8 \\
\text { Oे } \\
\text { i } \\
\text { in }\end{array}$} & \multirow{2}{*}{$\begin{array}{l}\stackrel{R}{1} \\
\text { d }\end{array}$} & \multirow{2}{*}{$\begin{array}{l}\stackrel{2}{\vdots} \\
\infty \\
\infty\end{array}$} & \multirow[b]{2}{*}{ 厌 } & \multirow[b]{2}{*}{ II } & \multirow[b]{2}{*}{ 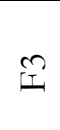 } & \multirow{2}{*}{ 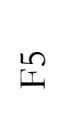 } & \multirow[b]{2}{*}{ lit } & \multicolumn{2}{|c|}{ Total } \\
\hline & & & & & & & & & & & & & $\mathrm{n}$ & $\%$ \\
\hline \multicolumn{15}{|l|}{ Pintadas } \\
\hline Bicromia & 7 & 21 & 17 & 11 & 4 & 1 & 4 & - & - & - & - & 2 & 67 & $13,4 \%$ \\
\hline Engobo vermelho & 123 & 30 & 7 & 4 & 1 & - & - & 1 & - & - & - & - & 166 & $33,2 \%$ \\
\hline Engobo branco & 64 & 16 & 40 & 18 & 38 & 29 & 23 & 4 & 18 & 2 & - & 15 & 267 & $53,4 \%$ \\
\hline \multicolumn{15}{|l|}{ Plásticas } \\
\hline Acanalado & 20 & 20 & 18 & 21 & 8 & 9 & 3 & 5 & 7 & 2 & 2 & 10 & 125 & $24,4 \%$ \\
\hline Inciso & 58 & 54 & 88 & 54 & 57 & 24 & 7 & 1 & 1 & 1 & - & 3 & 348 & $67,8 \%$ \\
\hline Inc. e acanalado & 1 & 2 & 0 & 4 & 0 & 1 & 2 & - & 1 & - & - & - & 11 & $2,1 \%$ \\
\hline Ponteado & 2 & 3 & 2 & 2 & - & - & - & - & - & - & - & 1 & 10 & $1,9 \%$ \\
\hline Excisão & 2 & - & 7 & - & - & 1 & - & - & - & - & - & - & 10 & $1,9 \%$ \\
\hline Digitado ungulado & - & 1 & - & 1 & - & 1 & - & - & - & - & - & 1 & 4 & $0,8 \%$ \\
\hline Modelado & 1 & - & - & 1 & - & - & - & - & - & - & - & - & 2 & $0,4 \%$ \\
\hline Esfera aplicada & - & 1 & - & 1 & - & - & - & - & - & - & - & - & 2 & $0,4 \%$ \\
\hline Rolete aplicado & - & - & - & - & - & - & - & - & - & - & - & 1 & 1 & $0,2 \%$ \\
\hline
\end{tabular}

Tabela 14: Tipos de técnicas decorativas aplicadas nas cerâmicas de Cacoal.

No que se refere às técnicas de decoração plástica este atributo na ficha utilizada é o que concentra maior número de variáveis. Para a identificação da técnica considerou-se os gestos e instrumentos utilizados para sua execução. Apenas oito técnicas plásticas foram observadas nas decorações dos vasos do sítio Cacoal, entre elas são predominantes incisões (simples/duplas/múltiplas) e acanalados, que podem ser aplicadas sozinhas ou concomitantemente, e foram registradas em $94,3 \%$ de toda a amostra. No restante da amostra (cerca de 6\%) foram observados ponteados, excisões, digitado/ungulado, modelado e aplicações de esfera e rolete. A ocorrência dessas técnicas é bastante tímida, sendo o nível 40-50 aquele que apresenta maior variação no uso dessas técnicas. Isso reflete pouca variabilidade nas técnicas decorativas, e por outro lado, destaca uma uniformidade no amplo uso da incisão e acanalado. 
A observação com auxílio da lupa permitiu registrar vestígios de engobo e pintura dentro dos sulcos da superfície decorada, sendo comum a aplicação de técnicas plásticas e pintadas em um mesmo projeto decorativo (Gráfico 4). Contudo, a combinação de diferentes técnicas plásticas é bastante rara. Isso é interessante, pois demonstra uma escolha bastante distinta daquela já identificada na região de Amanã. Em Boa Esperança as análises demonstraram que embora pintura e engobo fossem predominantes, 15 técnicas plásticas foram usadas nas decorações, e a simples quantificação de associações dessas técnicas reconheceu outras 15 maneiras distintas de combiná-las (Gomes, 2011).

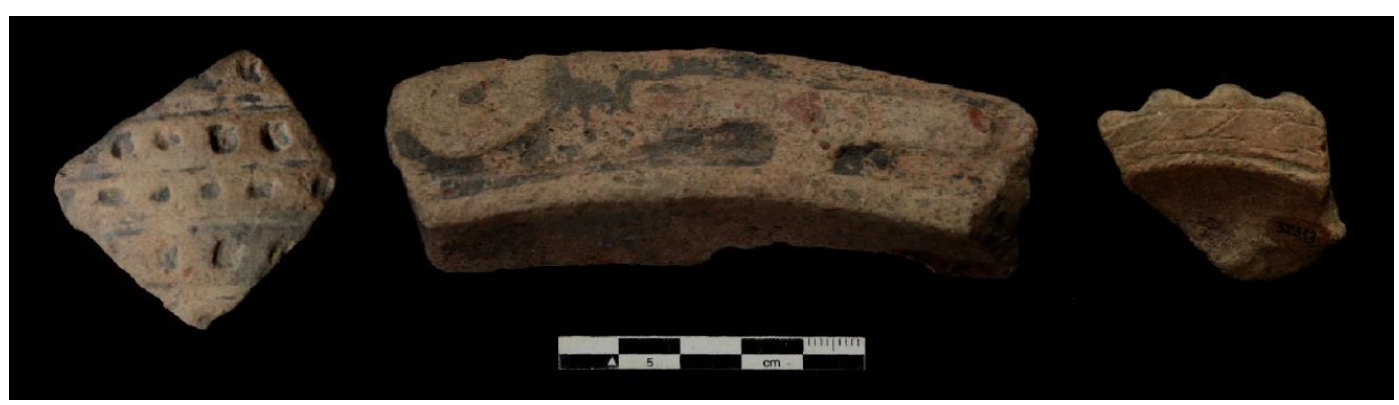

Figura 45: Fragmentos que apresentam diferentes técnicas aplicadas em conjunto.

Técnicas decorativas $\mathrm{x}$ níveis artificiais

$\square$ Técnicas concomitante $\square$ Técnicas pintadas $\square$ Técnicas plásticas

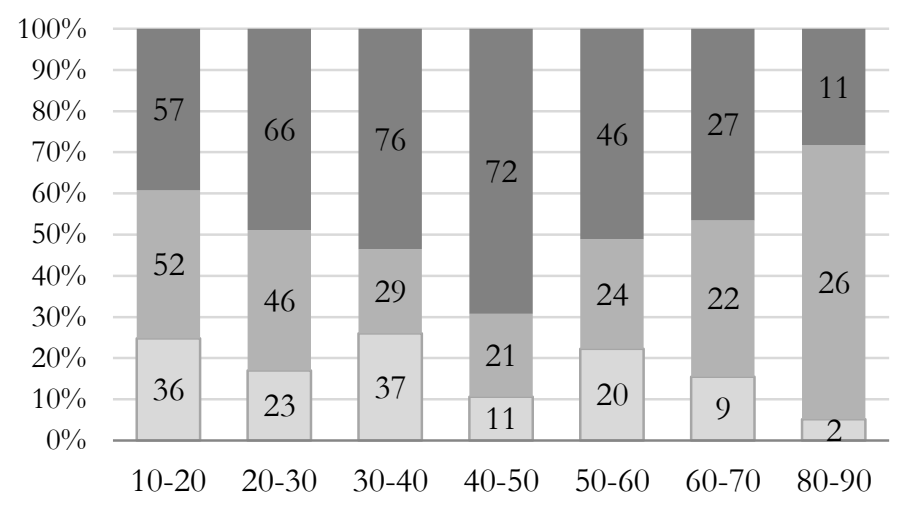

\begin{tabular}{|c|c|}
\hline Técnicas e combinações & $\mathbf{n}$ \\
\hline Acanalado & 102 \\
\hline Incisão & 350 \\
\hline ponteado & 3 \\
\hline digitado ungulado & 3 \\
\hline excisão & 3 \\
\hline esfera aplicada & 1 \\
\hline modelado & 2 \\
\hline acanalado com incisão & 8 \\
\hline acanalado com incisão e ponteado & 1 \\
\hline incisão com ponteado & 4 \\
\hline incisão com excisão e ponteado & 2 \\
\hline incisão com esfera aplicada & 2 \\
\hline Total & 481 \\
\hline
\end{tabular}

Gráfico 5: Frequencia nos níveis artificiais das técnicas decorativas.

Tabela 15: Combinações de diferentes técnicas.

Nas cerâmicas de Cacoal, não temos grande variabilidade de técnicas plásticas, que ocorrem predominantemente sozinhas, e com um leque pequeno de combinações. Digo isso, pois das 481 peças que apresentaram decoração plástica, em apenas 17 registrei o uso combinado de técnicas, a mais comum sendo incisão e acanalado acompanhados de ponteado (Tabela 13). Portanto, é possível dizer que há uma mudança radical nas escolhas e usos dessas técnicas quando comparamos com os complexos cerâmicos mais antigos identificados em Amanã. 
A análise do repertório decorativo foi realizada a partir de uma amostra de 116 peças, que tiveram seus elementos gráficos registrados através de fotografias, croquis e decalques. Nessa etapa, as informações corroboram que de modo predominante as bordas de vasos semi-esféricos foram aquelas que apresentaram condições de análise, sendo que $76 \%$ da amostra a decoração é distribuída perifericamente em relação a forma total do vaso. Considerando o precário estado de conservação das peças que apresentaram

Técnica Incisão simples Incisão dupla Acanalado

Estocado

Pintura, engobo e incisões Incisão com acanalado Incisões duplas e simples Outras

Total

$\mathrm{N} \quad \%$

\begin{tabular}{rr|}
36 & $31,0 \%$ \\
25 & $21,6 \%$ \\
20 & $17,2 \%$ \\
3 & $2,6 \%$ \\
11 & $9,5 \%$ \\
& \\
8 & $6,9 \%$ \\
5 & $4,3 \%$ \\
8 & $6,9 \%$ \\
116 &
\end{tabular}
decoração pintada, não foram analisados motivos pintados. Entre as técnicas plásticas, sobressaem as incisões simples. No que se refere aos elementos gráficos em si, aqueles observados na amostra estão sistematizados no quadro a seguir.

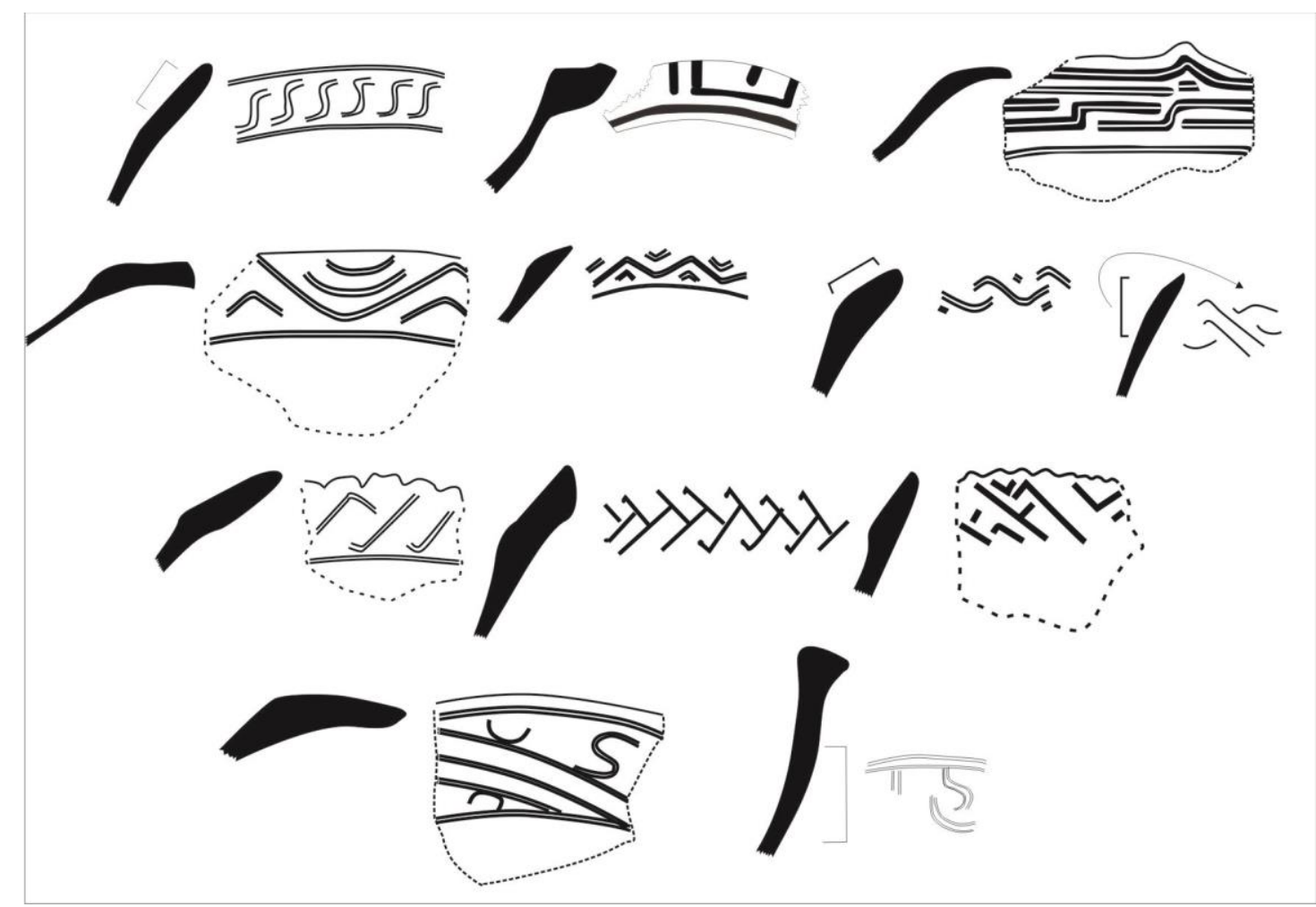




\begin{tabular}{|c|c|c|c|c|c|}
\hline \multicolumn{2}{|l|}{ Suporte } & \multicolumn{2}{|c|}{ Forma geral do vaso } & \multicolumn{2}{|c|}{ Distribuiçãodas formas } \\
\hline Borda & 52 & Esférica & 20 & Centro & 2 \\
\hline Lábio & 10 & Semi-esférica & 54 & Descentralizada & 18 \\
\hline Flange labial & 31 & Vertical & 12 & Intermediária & 6 \\
\hline Flange mesial & 3 & Gargalo & 2 & Periférica & 89 \\
\hline \multirow[t]{2}{*}{ Parede } & 20 & Irregular & 3 & Total & 0 \\
\hline & & Não ident. & 25 & Não ident. & 1 \\
\hline Total & 116 & & 116 & & 116 \\
\hline
\end{tabular}

Tabela 16: Informações da amostra da análise dos elementos gráficos.

O tratamento das linhas nas cerâmicas de Cacoal tem como principais características, um alto grau de linearidade, isto é, o design é totalmente reproduzido sem preencher todas as áreas, se restringindo a uma faixa de unidades gráficas, o que foi observado em 108 peças das 116 analisadas. Os desenhos retilíneos - incluem ziguezagues, triângulos, retângulos, linhas retas ou escalonadas, unidades gráficas convencionadas como "z", "v, "L" foram registrados em 96 peças, enquanto apenas 9 peças apresentaram de fato desenhos curvilíneos, isto é, círculos e linhas onduladas. O acabamento reto dos cantos é predominantereto na amostra, mas aqueles considerados intermediário e arredondado, geralmente se associou aos sulcos mais espessos como acanalados e incisões duplas e multiplas, e portanto mais relacionados ao efeito do tipo de técnica plástica usada, que uma preocupação estética específica.

\begin{tabular}{|c|c|c|c|c|c|c|}
\hline \multicolumn{7}{|c|}{ Grau de linearidade } \\
Grau & Linear & $\begin{array}{c}\text { Principalmente } \\
\text { linear }\end{array}$ & Intermediário & $\begin{array}{c}\text { Principalmente } \\
\text { não-linear }\end{array}$ & Tonal & Não Ident. \\
\hline Qnt & $\underline{\mathbf{1 0 8}}$ & 1 & 1 & 2 & 0 & 4 \\
\hline \multicolumn{7}{|c|}{ Escala de linearidade } \\
Muito curvilíneo (1)
\end{tabular}

Tabela 17: Tratamento das linhas 
Por fim, a regularidade do traço nos permite corroborar informações já apresentadas por Hilbert quando definiu a fase Caiambé (Conferir fotos no capítulo 2), já que variou bastante. Há peças nas quais a execução do motivo é realizada de forma pouco apurada, com pouca precisão resultando em um desing visualmente grosseiro (Figura 46 A), mas na maioria das vezes, quase sempre associada a incisão dupla, o desenho foi realizado com um alto grau de regularidade, com linhas bastante uniformes, executadas ao que parece com uma pressão constante

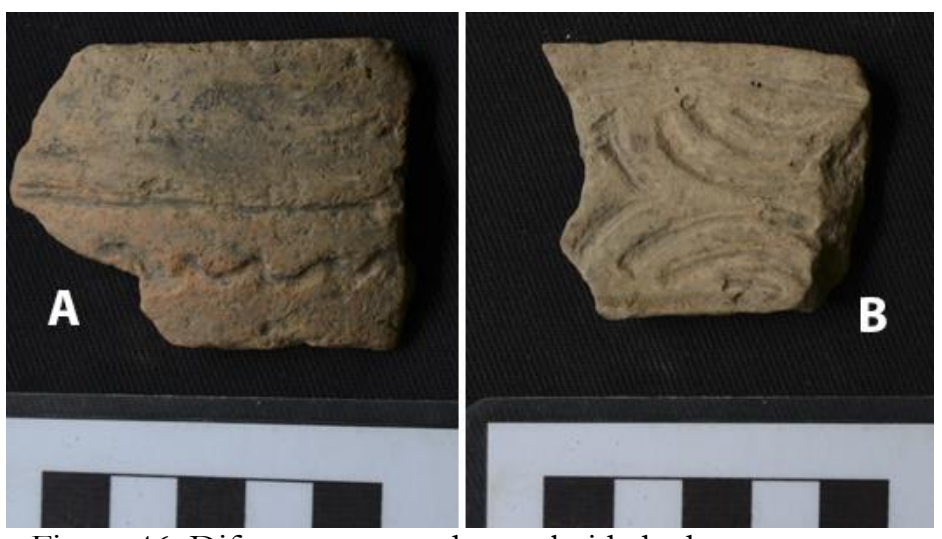

Figura 46: Diferentes graus de regularidade do traço. (Figura 46 B).

De modo geral a relação entre figura e fundo nessas cerâmicas é positiva, isto é, o a própria intervenção na superfície do vaso é motivo, isto se relaciona à escolha das técnicas de incisão usadas na maior parte da amostra. Em apenas 11 peças, considerou-se essa relação como negativa, ou seja, o desenho é formado pelo fundo em baixo relevo, sempre associada à técnica de acanalado. Por fim, ocorreu em um fragmento de flange mesial, típica da fase Tefé, uma relação contrastante, quando o desenho foi executado com a dependência entre figura e fundo.

Embora o repertório gráfico seja muito rico, mesclando diferentes graus de linearidade a decoração possui uma estrutura bastante rígida: linhas horizontais delimitam o campo onde os elementos aplicados são repetidos frequentemente no eixo horizontal de simetria, formando padrões unidimensionais em banda ou faixa (Shepard 1956; Washburn e Crowe, 1988). Os movimentos de translação e reflexão com translação são os mais usados. Apenas uma peça analisada apresentou o uso de simetria absoluta, enquanto 33 apresentavam um desing quase simétrico. O que ocorre na maioria das vezes é o uso balanceado dos elementos gráficos, cacarterizando uma falsa simetria, na qual quando olhada globalmente a decoração é simétrica, mas quando percorrido o motivo, ele apresenta pequenas distorções e assimetrias que acabam funcionando como um recurso para quebrar o ritmo visual. 


\begin{tabular}{|c|c|c|c|c|c|}
\hline \multicolumn{2}{|l|}{ Grau de simetria } & \multicolumn{2}{|l|}{ Movimentos } & \multicolumn{2}{|l|}{ Transformações } \\
\hline $\begin{array}{l}\text { Balanceado mas não } \\
\text { é simétrico }\end{array}$ & 11 & Reflexão & 2 & Fusão de motivos frequentes & 45 \\
\hline $\begin{array}{l}\text { Não é muito } \\
\text { simétrico }\end{array}$ & 4 & Rotação & & $\begin{array}{l}\text { transformação de motivos } \\
\text { frequentes }\end{array}$ & 14 \\
\hline Intermediário & 6 & Translação & 40 & $\begin{array}{l}\text { Motivo anômalo combinado com } \\
\text { motivos frequentes }\end{array}$ & 8 \\
\hline Quase simétrico & 33 & Translação com reflexão & 13 & Uso motivo anômalo & 2 \\
\hline Simetria & 1 & $\begin{array}{l}\text { Rotação e Translação c/ } \\
\text { reflexão }\end{array}$ & 3 & Não determinado & 47 \\
\hline Não identificado & 61 & & & & \\
\hline
\end{tabular}

Tabela 18: Simetria - informações resumidas.

Os elementos gráficos mais comuns na decoração são linhas retas únicas e paralelas horizontais, verticais e diagonais; linhas escalonadas; espirais retangulares, linhas onduladas, linhas em ziguezague e curvas (ondas). Essas linhas podem variar de 1 a $5 \mathrm{~mm}$ de espessura a depender da técnica usada, se incisão simples ou com instrumento de ponta dupla.

Um motivo típico é formado por linhas paralelas diagonais de $2-4 \mathrm{~cm}$ de comprimento, que em suas extremidades são adicionadas linhas curtas para a esquerda ou direita. Estas linhas curtas também podem ser usadas para preencher os campos vazios entre linhas diagonais. Há certa variação de como tais combinações de elementos são feitas, formando dessa maneira, motivos distintos que são repetidos e mesclados com outros menores (retângulos, pontos, linhas curtas).

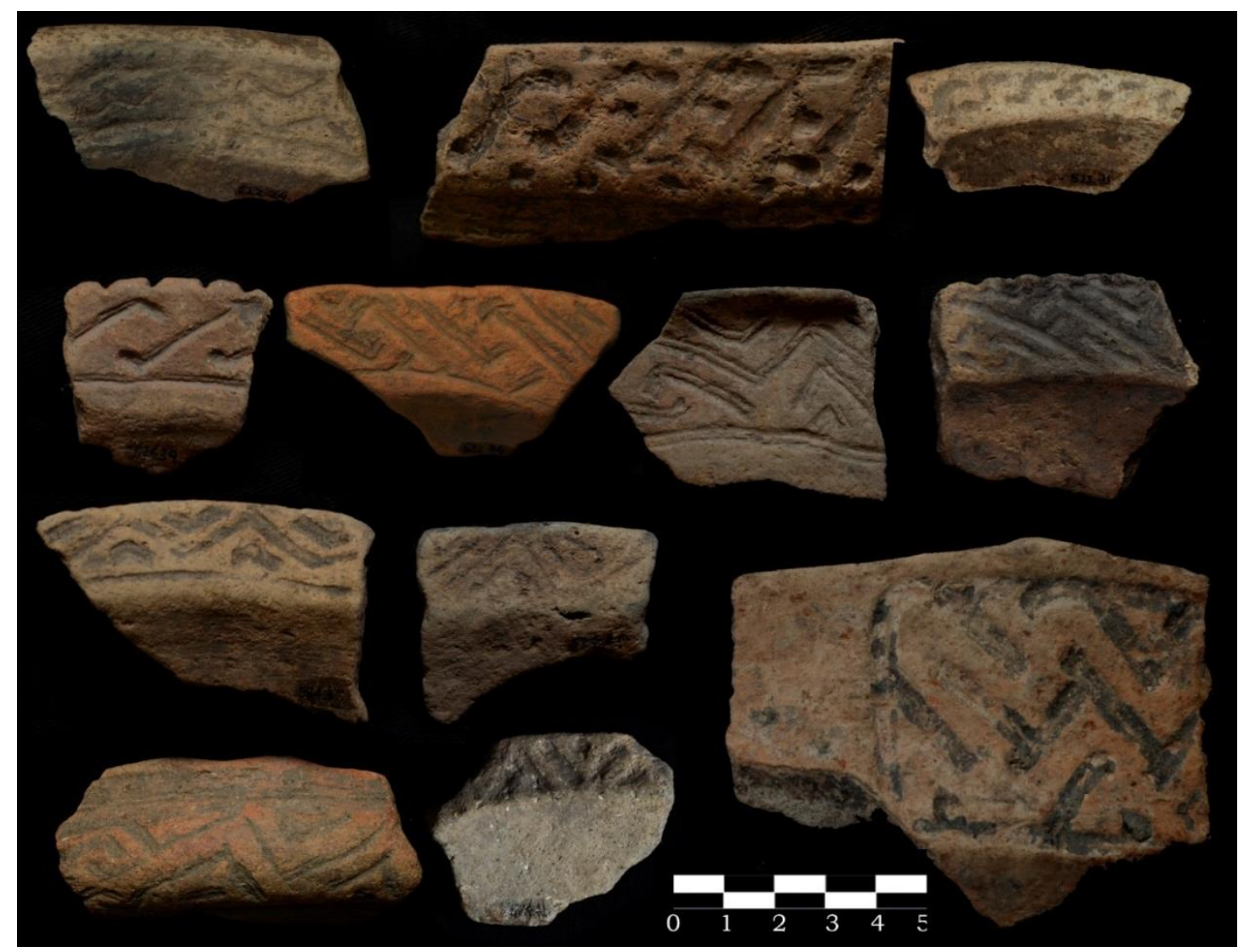

Figura 47: Bordas diagnósticas da fase Caiambé, destaca-se aqui que o motivo gráfico "v" ocorre com diferentes variações, além das linhas zigue-zague e " $z$ " 


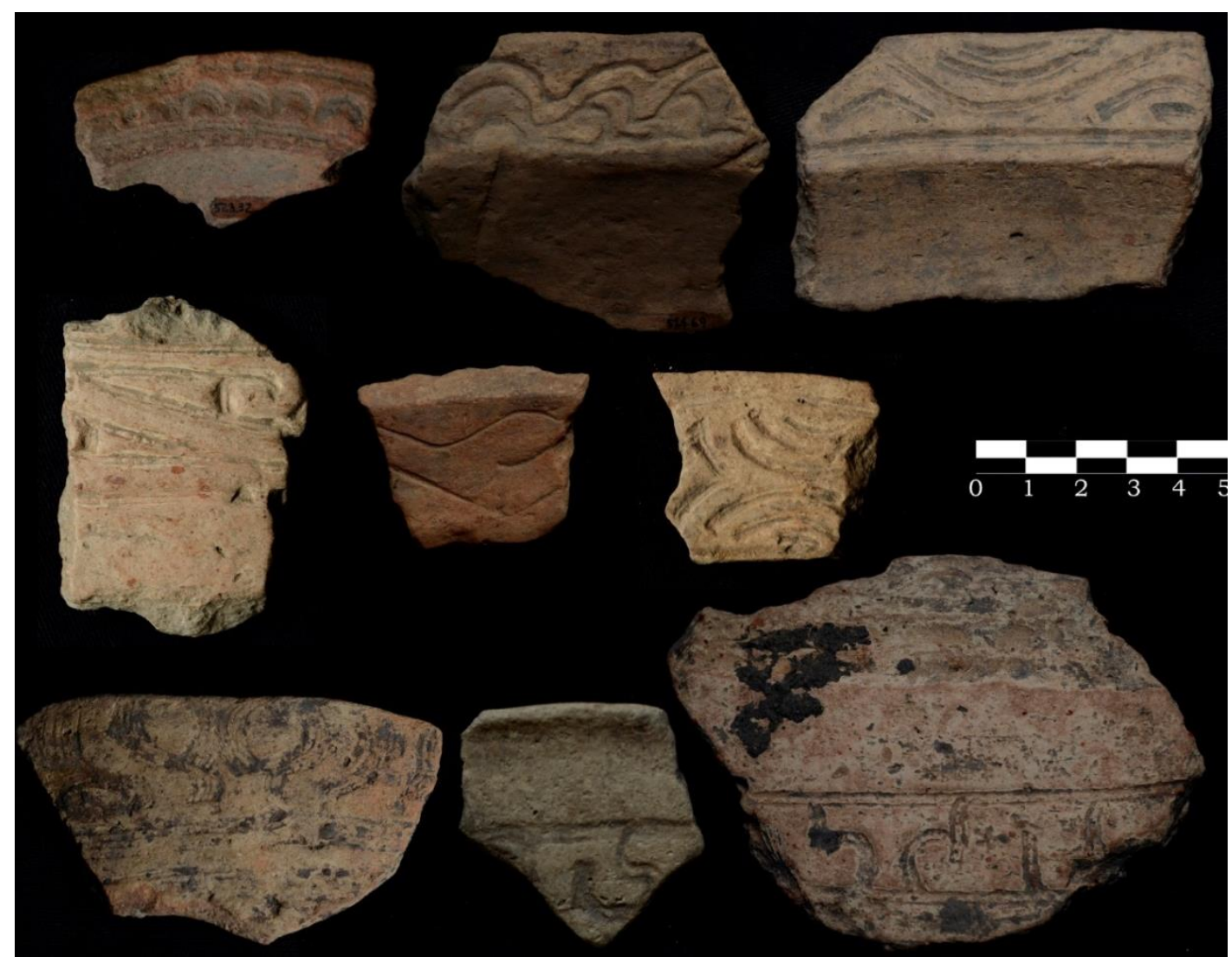

Figura 48: Fragmentos cerâmicos exemplares do desing mais curvilíneo.

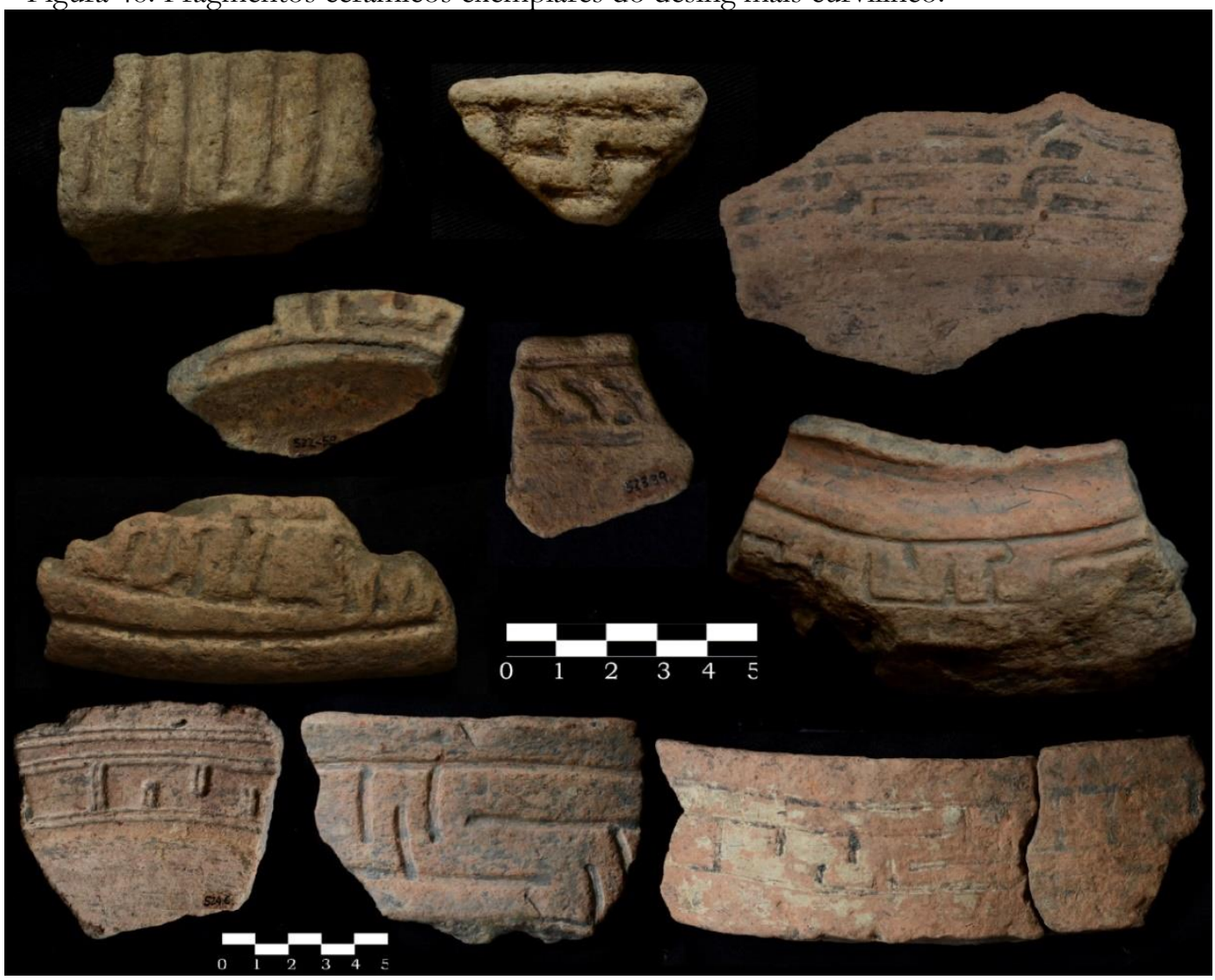

Figura 49: Fragmentos cerâmicos exemplares do desing retilíneo. Destaque para as linhas escalonadas e as pequenas linhas retas (aspas), aplicadas de diferentes maneiras, mas sempre delimitadas por linhas horizontais que limitam o campo decorativo. 


\subsection{Sítio São Miguel do Cacau}

\section{Pastas e queima}

Considerados também como antiplásticos básicos: caraipé, cauixi, minerais (grãos de quartzo e hematita), nódulos de argila e carvão, foram identificados no sítio São Miguel. Com exceção de um fragmento que apresentou somente antiplástico mineral, esses aditivos foram observados sempre associados, que sem levar em consideração suas proporções, formaram 22 misturas distintas. Em todos os níveis artificiais a presença conjunta do cauixi, hematita e/ou carvão é a mais relevante, enquanto as outras misturas ocorrem esporadicamente. No gráfico abaixo, fica claro o predomínio de cauixi na produção cerâmica, na amostra, formada por 297 peças, apenas 6 apresentaram caraipé como antiplástico principal, enquanto $97,3 \%$ das peças apresentaram cauixi.

\section{Frequência de antiplásticos}

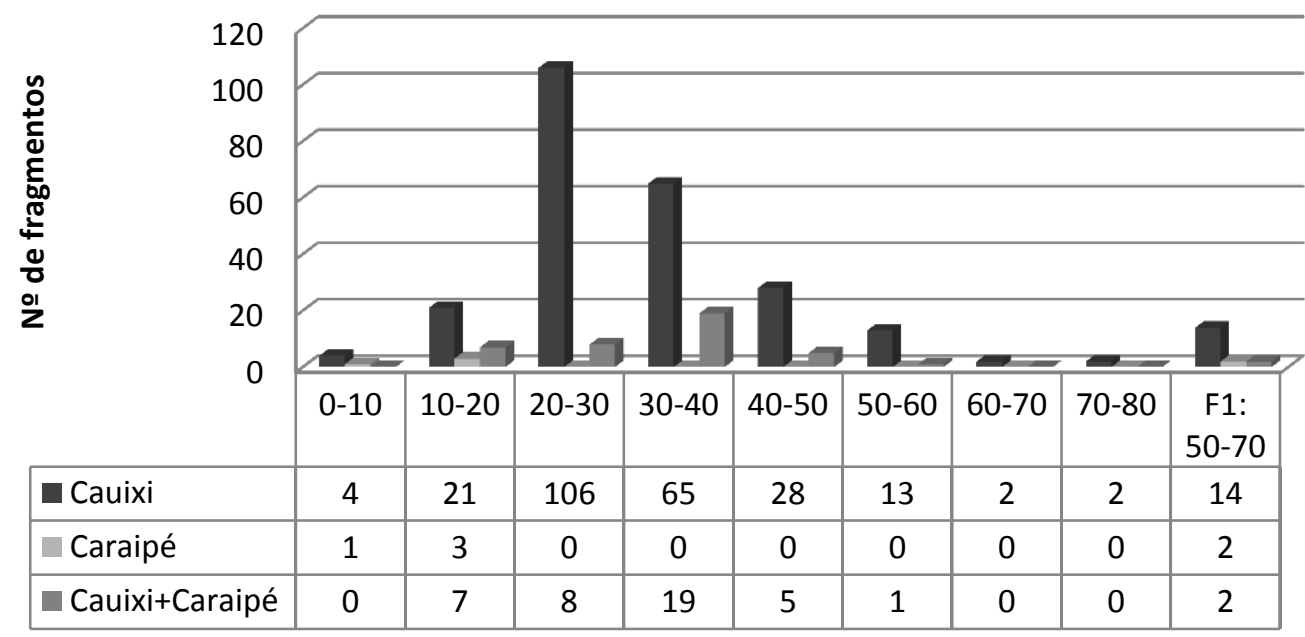

Gráfico 6: Frequência de antiplásticos do sítio São Miguel do Cacau.

\begin{tabular}{r|cccc|}
\hline Coloração & $\begin{array}{c}\text { Face } \\
\text { Interna }\end{array}$ & $\%$ & $\begin{array}{c}\text { Face } \\
\text { Externa }\end{array}$ & $\%$ \\
\hline Branco & 11 & $4 \%$ & 11 & $4 \%$ \\
Laranja & 164 & $55 \%$ & 145 & $49 \%$ \\
Preta & 3 & $1 \%$ & 9 & $3 \%$ \\
Vermelha & 3 & $1 \%$ & 6 & $2 \%$ \\
Marrom & 41 & $14 \%$ & 39 & $13 \%$ \\
Laranja & 75 & $25 \%$ & 87 & $29 \%$ \\
forte & & & & \\
\hline
\end{tabular}

Tabela 19: Ocorrência das colorações das superfícies na amostra.
A coloração da superfície da cerâmica e o tipo de quiema nos informam sobre certa homegeneidade das pastas neste sítio. Cerca de $80 \%$ das peças apresentam coloração alaranjada (variando entre os tons mais claros e mais fortes) e a queima 
oxidante completa foi registrada em 42,6\% da amostra, enquanto 41,5\% apresenta queima oxidante incompleta. Preferencialmente as cerâmicas parecem ter sido quiemadas em ambiente aberto, cujo controle da temperatura é difícil e imprimindo grande variação na queima final. Apenas 15,9\% da amostra apresenta núcleos completamente escurecidos, o que sugere um ambiente mais controlado de quiema, embora não seja possível afirmar que se trata de uma técnica deliberadamente usada para produzir um ambiente redutor, pois a depender da posição do vaso durante o processo de queima, microambientes redutores podem ser formados (Citar).

\begin{tabular}{|c|c|c|c|c|c|c|c|}
\hline Queima & Unid & Feição & $\begin{array}{c}\text { Urna } \\
572\end{array}$ & $\begin{array}{c}\text { Urna } \\
573\end{array}$ & $\begin{array}{c}\text { Urna } \\
685\end{array}$ & $\mathbf{n}$ & $\%$ \\
\hline Oxidante & 116 & 11 & 15 & 16 & 59 & 217 & $42,6 \%$ \\
\hline Núcleo redutor & 83 & 8 & 0 & 5 & 24 & 120 & $23,6 \%$ \\
\hline $\begin{array}{l}\text { Incompleta } \\
\text { (Oxidante Face externa) }\end{array}$ & 47 & 4 & 4 & 0 & 12 & 67 & $13,2 \%$ \\
\hline Incompleta (Redutora) & 30 & 3 & 6 & 5 & 37 & 81 & $15,9 \%$ \\
\hline $\begin{array}{l}\text { Incmpleta } \\
\text { (Oxidante Face interna) }\end{array}$ & 21 & 1 & 0 & 0 & 2 & 24 & $4,7 \%$ \\
\hline total & 297 & 27 & 25 & 26 & 134 & 509 & $100 \%$ \\
\hline
\end{tabular}

\section{Tratamento de superficie}

No sítio São Miguela analise condida por Furquim (2014), destacou a presença da barbotina de forma frequente, o que parece ser uma particularidade deste sítio. A barbotina como definida por La Salvia e Brochado (1989), trata-se da aplicação de um fino banho de argila. O mesmo efeito pode ser obtido no alisamento fino em superfícies umidecidas, neste caso, chamado de pseudobanho (Idem, p17). Furquim considerou a barbotina como Lima (2014:112) paras as cerâmicas do Rio Unini, como uma película que reveste os vasos interna e/ou externamente, de espessura mais fina que o engobo apresentando características diferentes das pastas dos vasos. Em todo caso, não possuímos maiores informações da associação de sua ocorrência, mas chama atenção que das peças que apresentaram algum tipo de tratamento, 50\% delas tiveram esse tipo de acabamento. O escovado foi observado em $25 \%$ da amostra, sendo relevante como no Sítio Cacoal.

\section{Decoração: técnicas e repertório gráfico}

$\mathrm{Na}$ amostra proveniente da unidade de escavação, do total de peças analisadas, 187 $(63 \%)$ apresentaram algum tipo de decoração. A grande maioria das peças apresenta decoração na face externa do vaso $(70 \%)$, com predomínio das técnicas pintadas de decoração, sendo o engobo branco a técnica mais frequentemente usada, enquanto que a 
presença do engobo vermelho é reduzida (8 peças) e a pintura, embora pouco preservada tem presença relevante, principalmente entre os 10 e $40 \mathrm{~cm}$ do pacote escavado. Já entre as técnicas plásticas de decoração, o acanalado (45 peças) e a incisão (15 peças) foram aquelas mais observadas por Furquim, que não distinguiu a ocorrência de incisões duplas ou múltiplas que conferem o mesmo efeito visual que o acanalado.

Quando consideramos, toda a amostra do sítio São Miguel, o percentual de frequência das técnicas pintadas e plásticas é semelhantes em todos os contextos analisados, seja feição ou urnas. Portanto, de modo geral, é expressivo o uso do engobo branco, em 37,7 \% da amosra total, seguido do acanalado em 25,9\% e da pintura bicrômica (vermelho ou laranja sobre engobo branco) e incisões, ambas presentes em $14 \%$ das peças. Importante ressaltar ainda, que outras técnicas plásticas como o digitado e raspado foram registradas, mas ocorreram de forma rara. Neste sítio, assim como no anterior, a execução da decoração parece ser bastante rígida, com baixa variabilidade de técnicas sendo aplicadas.

\begin{tabular}{|l|cccccc|}
\hline Técnicas & Unidade & Feição & $\begin{array}{c}\text { Urna } \\
573\end{array}$ & $\begin{array}{c}\text { Urna } \\
685\end{array}$ & $\mathrm{n}$ & $\%$ \\
\hline Pintadas & & & & & & \\
\hline Pintura & 29 & 0 & 0 & 21 & 50 & $\underline{\mathbf{1 4 , 1} \%}$ \\
\hline Engobo vermelho & 8 & 0 & 8 & 5 & 21 & $5,9 \%$ \\
\hline Engobo branco & 76 & 11 & 9 & 38 & 134 & $\underline{\mathbf{3 7 , 7} \%}$ \\
\hline Negativo & 1 & 0 & 0 & 0 & 1 & $0,3 \%$ \\
\hline Plásticas & & & & & & \\
\hline Acanalado & 45 & 0 & 9 & 38 & 92 & $\underline{\mathbf{2 5 , 9} \%}$ \\
\hline Inciso & 15 & 5 & 6 & 24 & 50 & $\underline{\mathbf{1 4 , 1} \%}$ \\
\hline Aplique modelado & 1 & 0 & 0 & 0 & 1 & $0,3 \%$ \\
\hline Digitado & 3 & 1 & 0 & 0 & 4 & $1,1 \%$ \\
\hline Raspagem & 2 & 0 & 0 & 0 & 2 & $0,6 \%$ \\
\hline & 180 & 17 & 32 & 126 & 355 & $100 \%$ \\
\hline
\end{tabular}

Tabela 20: Ocorrência das técnicas decorativas na amostra. Destaque para o engobo branco presente em $37,7 \%$ da amostra.

Os motivos mais freqüentes são as linhas incisas duplas em formas geométricas aplicados preferencialmente nas bordas, lábios e paredes externas. Os acanalados retos simples ou em linhas duplas são recorrentes nas paredes dos vasos, enquanto que aqueles cujas linhas são mais curvilíneas são, em maioria, aplicados sobre flanges labiais e associados às incisões. Como no sítio Cacoal, frequentemente as decorações plásticas ocorre concomitante ao engobo branco, sendo comum que o único local onde é observável é dentro dos sulcos da decoração plástica. 

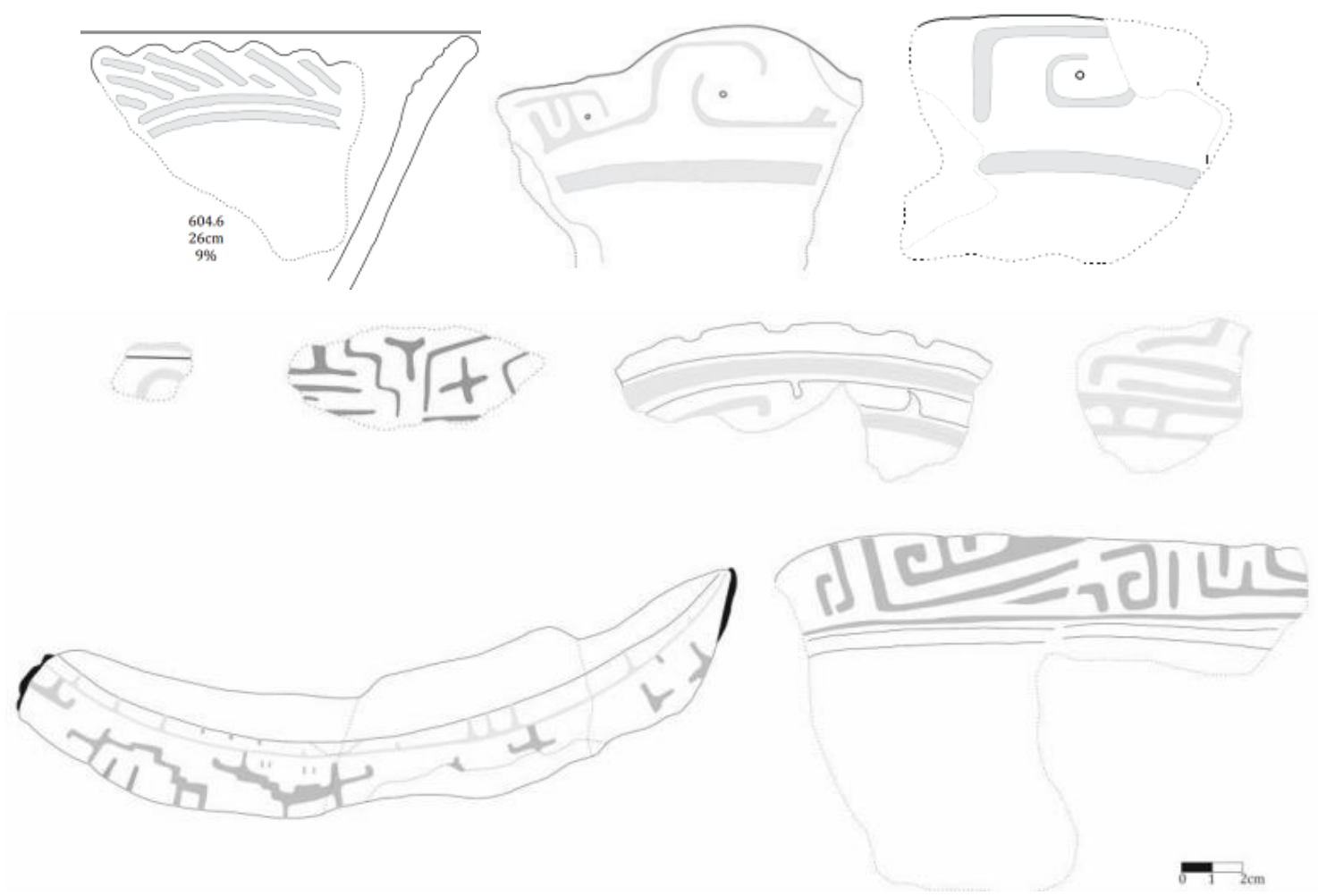

Figura 50: Repertório gráfico das cerâmicas do sítio São Miguel. Desenhos: Laura Furquim.

$\mathrm{Na}$ unidade de escavação apenas 28 lábios decorados foram identificados sendo aplicadas seis diferentes técnicas decorativas: 12 com acanalados, 5 lábios serrilhados, 5 com engobo, 4 com incisões, 1 lábio modelado e 1 pintado. Embora a baixa frequência, os lábios serrilhados podem ser considerados um traço diagnóstico da fase Caiambé (Costa, 2012; Gomes, 2011).

De modo geral, os motivos não se distinguem muito do observado no sítio Cacoal, mas a análise do repertório gráfico - apesar da baixa frequência de peças passíveis de análise, que somaram ao todo 16 - indica uma preferência pelos motivos mais retilíneos, como as linhas escalonadas, além das diagnósticas faixas de linhas curtas paralelas (v).
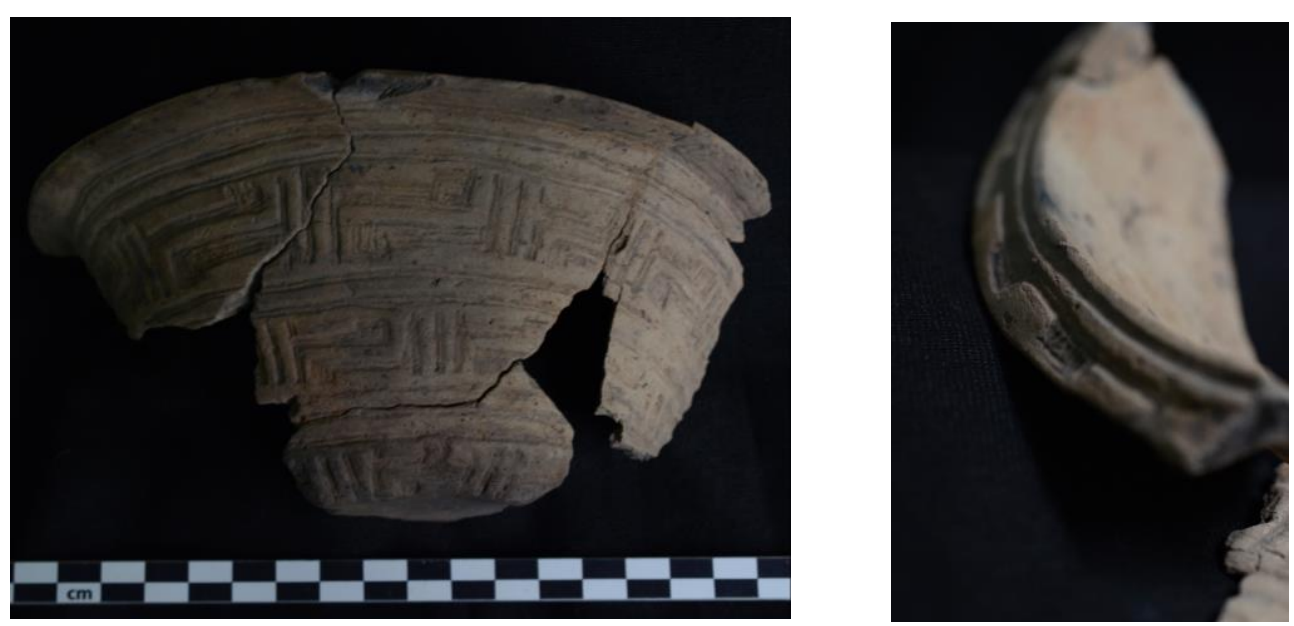

Figura 51: Exemplo de vaso com decoracao retílinea. à esquerda detalhe do lábio inciso. 


\section{Morfologias}

Os fragmentos de bordas analisados indicam que os vasos são predominantemente de contorno simples e irrestritivo. Vasos de contorno composto puderam ser inferidos a partir de $25 \%$ das peças que permitram observar este atributo. As formas restritivas, estão dispersas por toda a cada arqueológica, não havendo concetrações específicas nos níveis artificiais. As formas verticais foram as menos representativas, inferidas em 8,5\% da amostra de bordas e concentradas entre os níveis $20-50 \mathrm{~cm}$ de profunidade.

As bordas preferencialmente são retas (37\%), seguidas daquelas com reforço externo $(33 \%)$ e expandidas $(21 \%)$. As bordas reforçadas internamente somam $8 \%$ da amostra e estão presente entre os 20 e $50 \mathrm{~cm}$ de profunidade. Bordas contraídas são pouco frequentes, ocorrendo em apenas $1 \%$ da amostra, e possuem quase sempre inclinação introvertida. Há predomínio das bordas extrovertidas (43\%) e extrovertidas tipo flange (11\%), portanto mais de metade da amostra. O restante é composto por bordas cuja inclinação é direta $(37 \%)$ e introvertida $(9 \%)$. Entre as formas de lábios, predominam os arredondados $(56 \%)$, planos (25\%), afilados (12\%) e biselados $(7 \%)$, sem qualquer diferenciação expressiva ou concentração de frequência em agum nível artificial. As bases analisadas somaram 57 fragmentos, sendo marjoritariamente planas (82\%) ou com marcas de folha $(16 \%)$ que foram coletadas apenas a partir dos $30 \mathrm{~cm}$ de profunidade. Diferente do sítio Cacoal, não foi identificada decoração nessas peças.

Furquim (2014) apresenta 55 reconstituições de morfologias para o sítio São Miguel, contudo nesta anlisa consideramos 23, visto que determinadas morfologias não apresentam diferenciações na estrutura de composição da forma, mas variam no tamanho e volume, além da variabilidade de tipos de bordas e lábios. Entre essas morfologias 17 também foram registradas no sítio Cacoal. Chama atenção, no entanto, a frequência de vasos com contorno composto - restritivo e irrestrivo.

Por fim, embora ocorrendo pontualmente, uma morfologia de vaso com flange mesial foi registrada, especificamente no interior da urna 685. Em toda amostra da unidade de escavação apenas quatro apliques foram registrados, entre os 30 e $50 \mathrm{~cm}$, sendo dois zoomorfos e dois abstratos. Um fragmento de alça foi

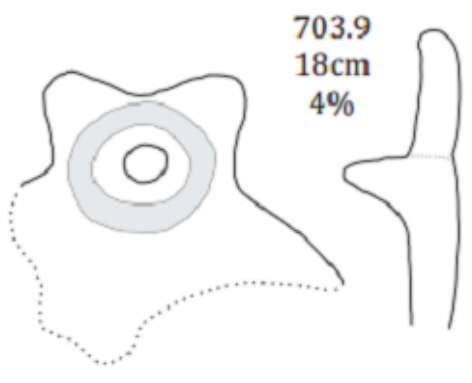
identificado. 
Conjunto 1: Morfologias irrestritivas de contorno simples

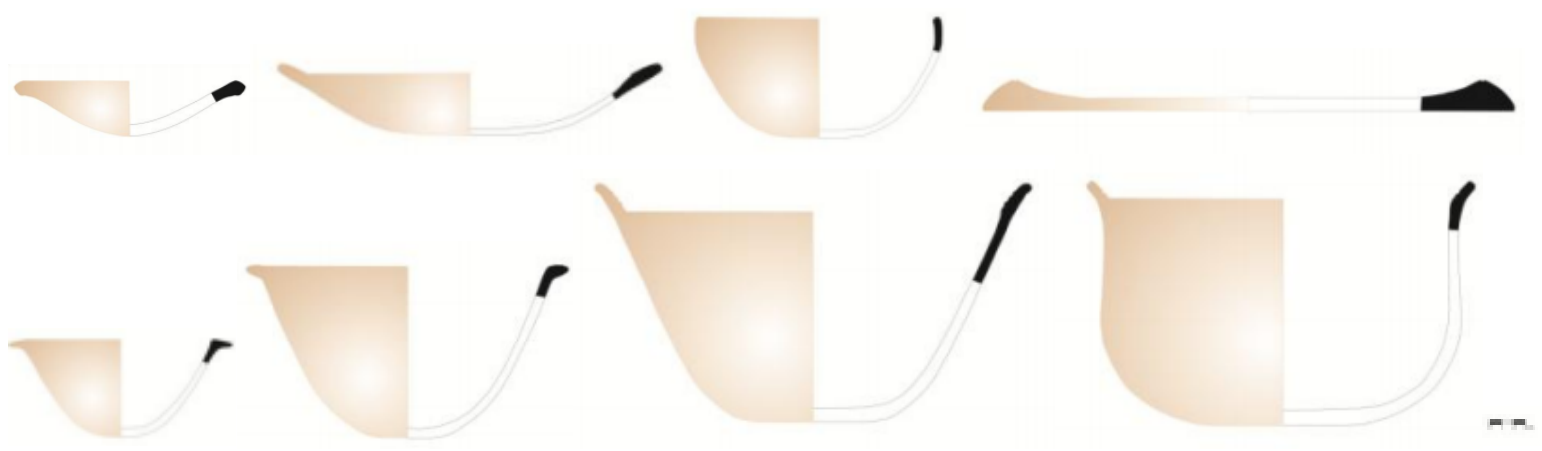

Conjunto 2: Morfologias irrestritivas de contorno composta

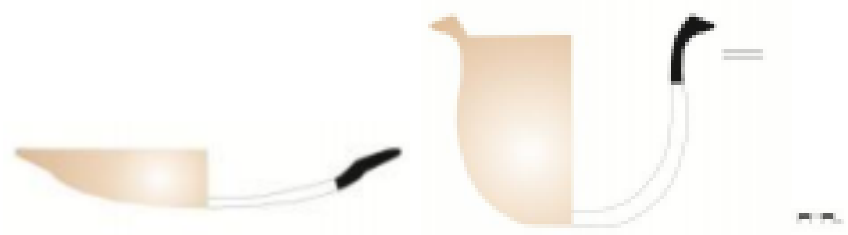

Conjunto 3: Morfologias restritivas de contorno simples

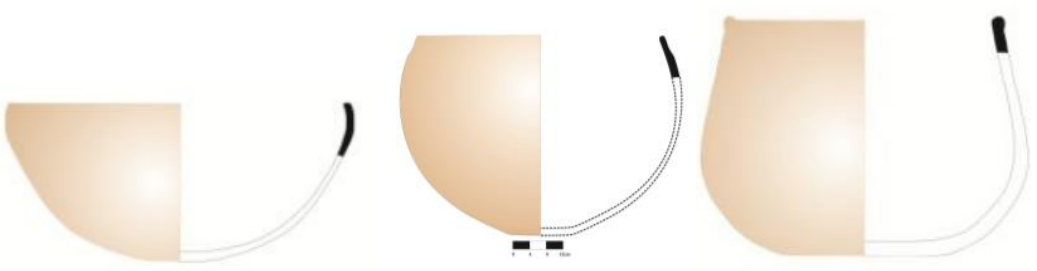

Conjunto 4: Morfologias restritivas de contorno composto
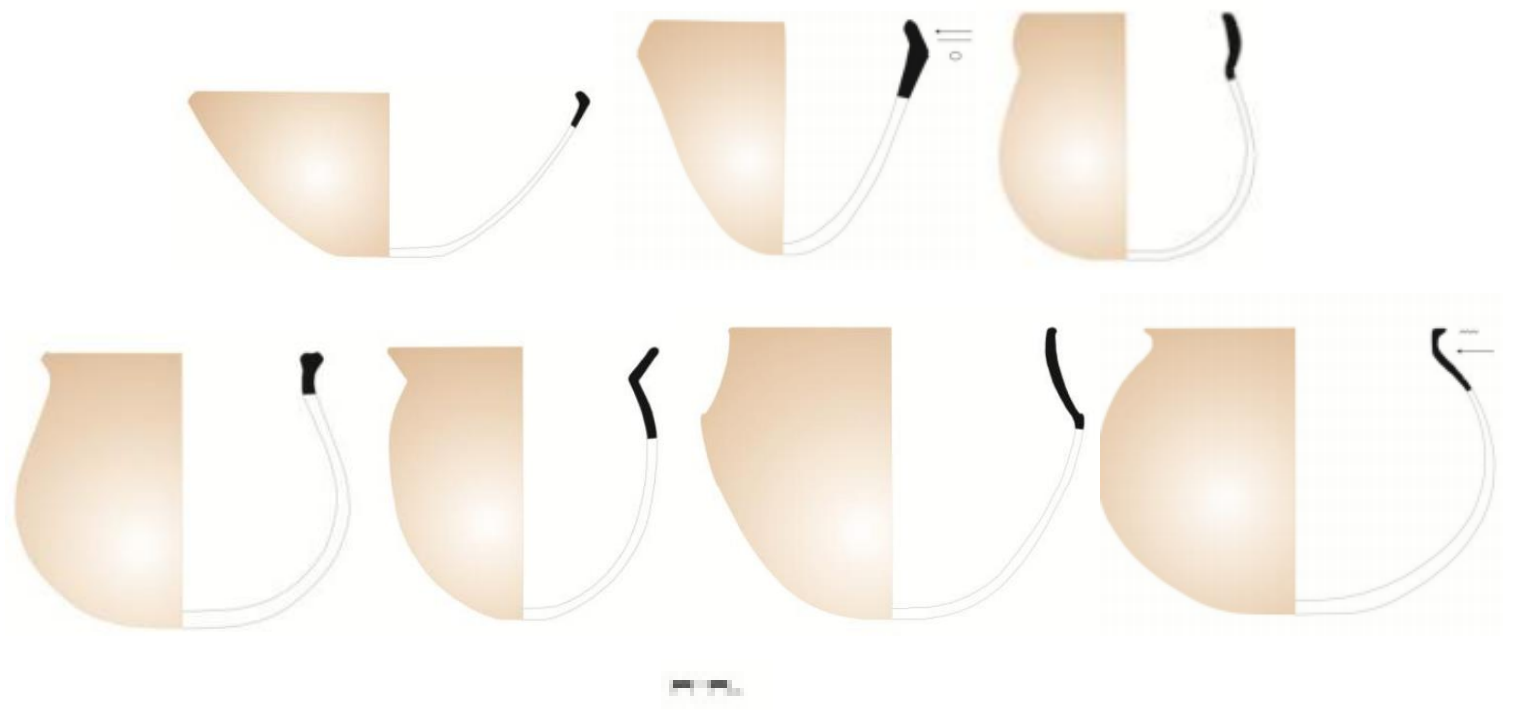
Conjunto 5: Morfologias verticais

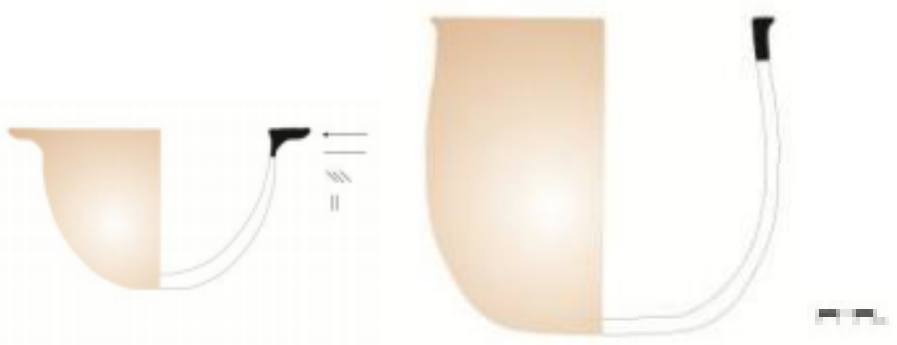

Conjunto 6: Morfologias restritivas de contorno complexo
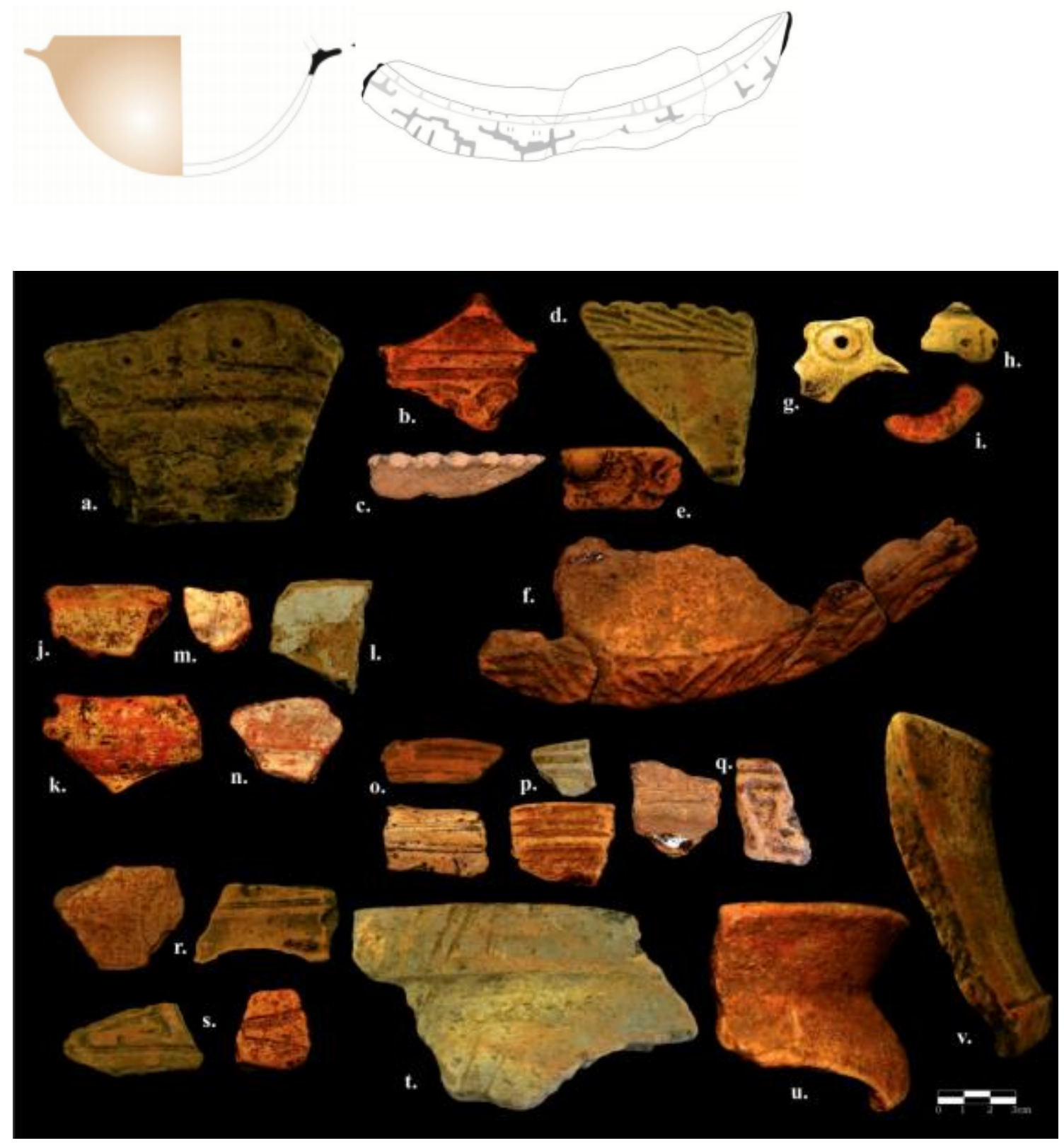

Figura 52: Fragmentos diagnósticos do sítio São Miguel do Cacau provenientes da unidade de escavação. A) Flange labial; b) Borda irregular pintada de vermelho sobre engobo branco; c) lábio serrilhado; d) borda extrovertida com lábio serrilhado de vaso irrestritivo com motivo típico Caiambé; e) Fragmento de borda com esfera aplicada; f)prato típico da fase Caiambé; g - i)apliques e alça; $j-n)$ fragmento com engobo branco; o-q) fragmento parede com incisão; $r-s$ ) fragmentos de paredes com engobo vermelho; t-v: bordas de formas compostas. (Fotos de Laura Furquim) 


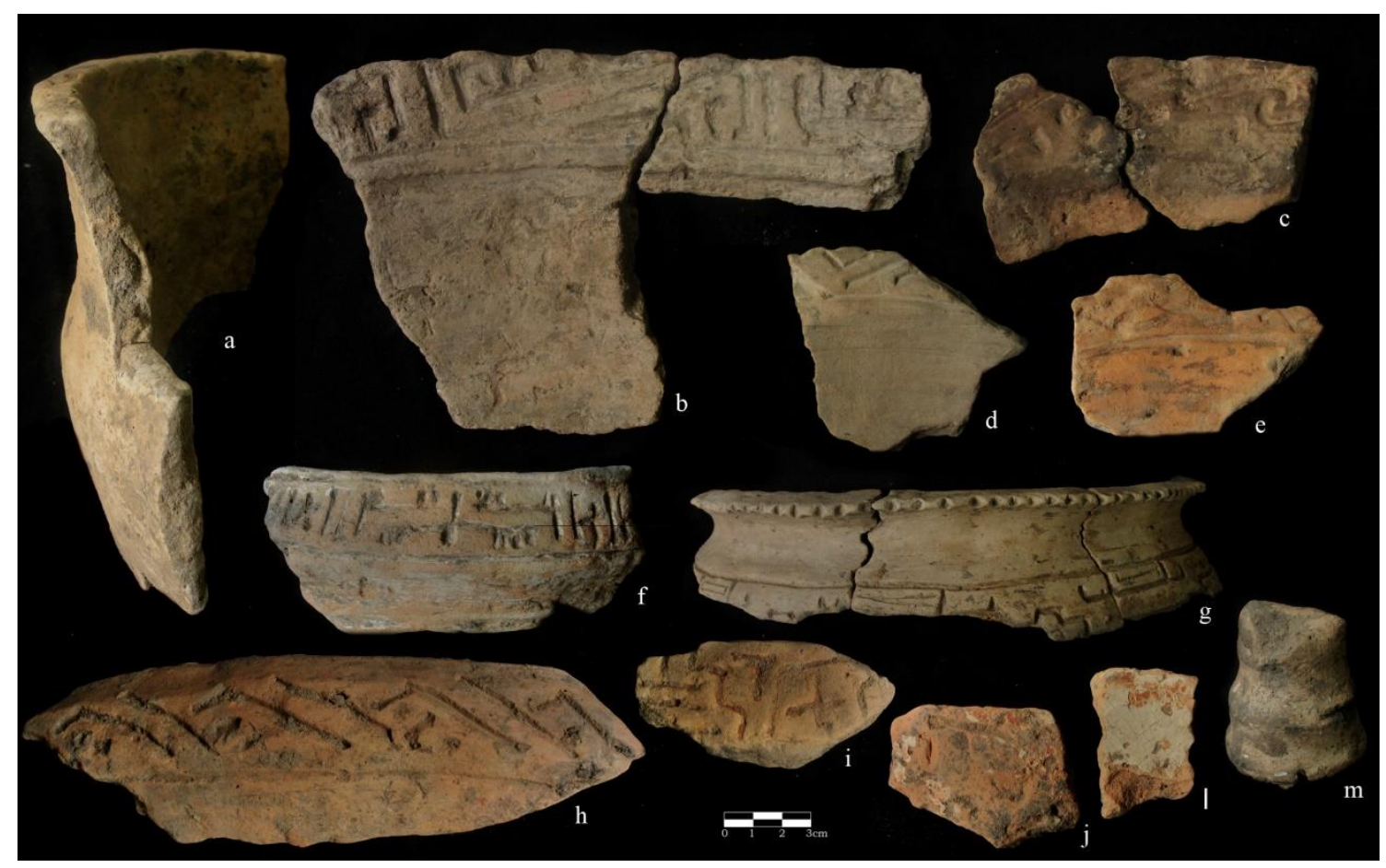

Figura 53: Material cerâmico coletado no interior da urna: a) Grande fragmento de um vaso sem decoração; b;c) Bordas flangeadas de vasos irrestritivos com decoração realizada com incisões duplas; d;e) Bordas de vasos irrestritivos com decoração inicsa em motivos retos bastante comum nas cerâmicas do sítio; f) Borda com decoração incisa dupla; g) Borda de vaso irrestritivo com decoração incisa dupla e lábios externos serrilhados (este padrão decorativo é comum no sítio); h)Borda de vaso restritivo com uma faixa de decoração plástica e vestígios de engobo branco; i) Parte de vaso de contorno composto, decorado com incisões e lábios serrilhados; j) parede decorada com incisões e vestígios de engobo vermelho; l) parede decorada com uma faixa de incisões, com motivo semelhante às peças $\mathrm{d}$ - e; $\mathrm{m}$; $\mathrm{n}$ ) fragmentos de parede com pintura vermelha sobre engobo branco; o) Aplique maciço. Fotos: Jaqueline Gomes. 
3. As urnas funerárias

As urnas analisadas são provenientes dos sítios Cacoal e São Miguel, bem como de Bom Jesus do Baré. Embora no sítio Boa Esperança também tenha ocorrido resgate de duas urnas, elas ainda estão passando por processo de higienização para posteriores análises morfológicas e decorativas no âmbito de um projeto de inciação cientifica sobre conservação (Fernando, 2015). O objetivo desta sessão é detalhar as características das próprias cerâmicas e seus contextos, visto que a analise de peças inteiras permite um grau de compreensão maior da produção e uso desses objetos.

\subsection{Sítio Bom Jesus do Baré}

No sítio Bom Jesus do Baré, em uma área de $4 \mathrm{~m}^{2}$ foram coletadas quatro urnas, duas delas desmontadas durante os procedimentos de escavação (PN 517 e 518) e outras duas coletadas com sedimento visando tratamento posterior ( $\mathrm{PN} 516$ e 520), porém outras cinco urnas foram evidenciadas nos limites da área escavada, mas não puderam ser coletadas naquele momento (Figura 54).

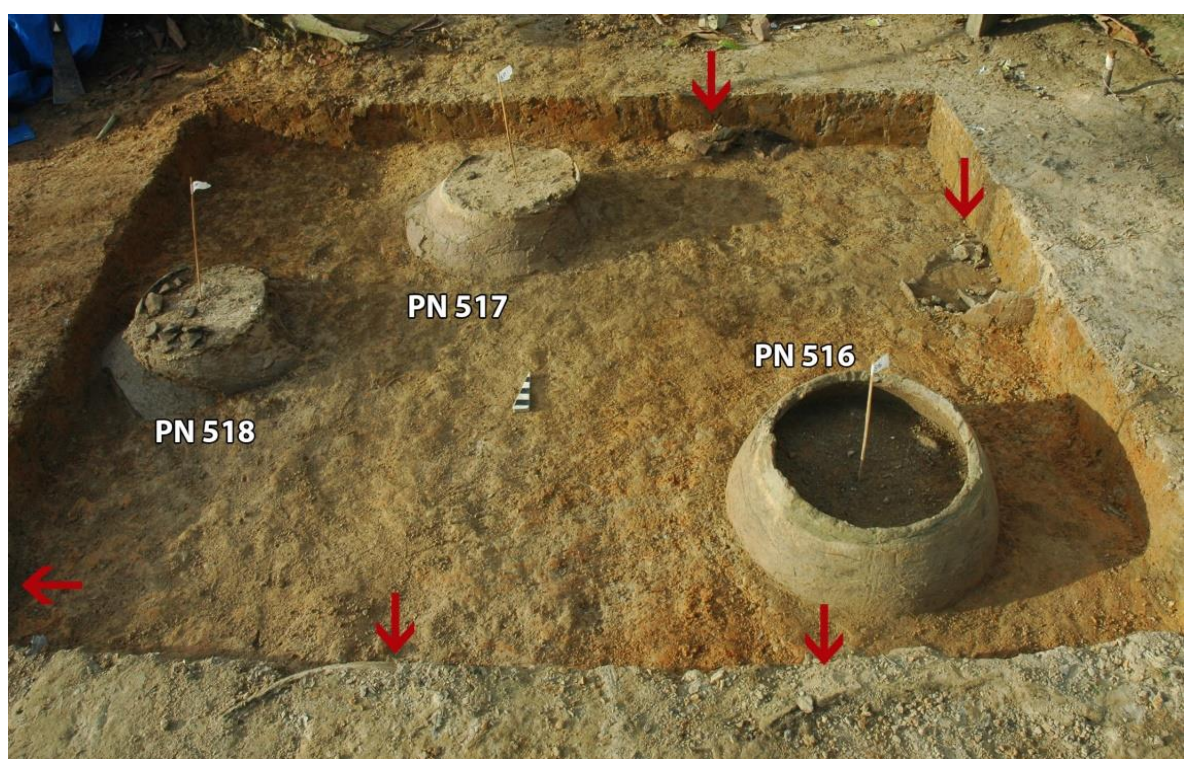

Figura 54: Escavação do sítio Bom Jesus do Baré. As setas vermelhas indicam as urnas que não foram coletadas. Foto: Bernardo Costa.

PN 516

Esta urna foi a que se apresentou mais íntegra, embora toda sua borda já estivesse desteriorada quando foi resgatada. Ainda em campo foi evidenciado em seu interior um vaso emborcado, servindo como provável tampa. Apenas em 2011 a escavação foi continuada, e com a identificação de um sepultamento, todo procedimento de recuperação desses vestígios foi realizado por Anne Rapp Py-Daniel (Cf Capítulo 2). Após seu 
esvaziamento, objetivando sua conservação, a higienização, desmontagem e remontagem com estabilização da peça foram realizadas por Valdirene Moraes. Durante esses procedimentos realizamos sua análise.

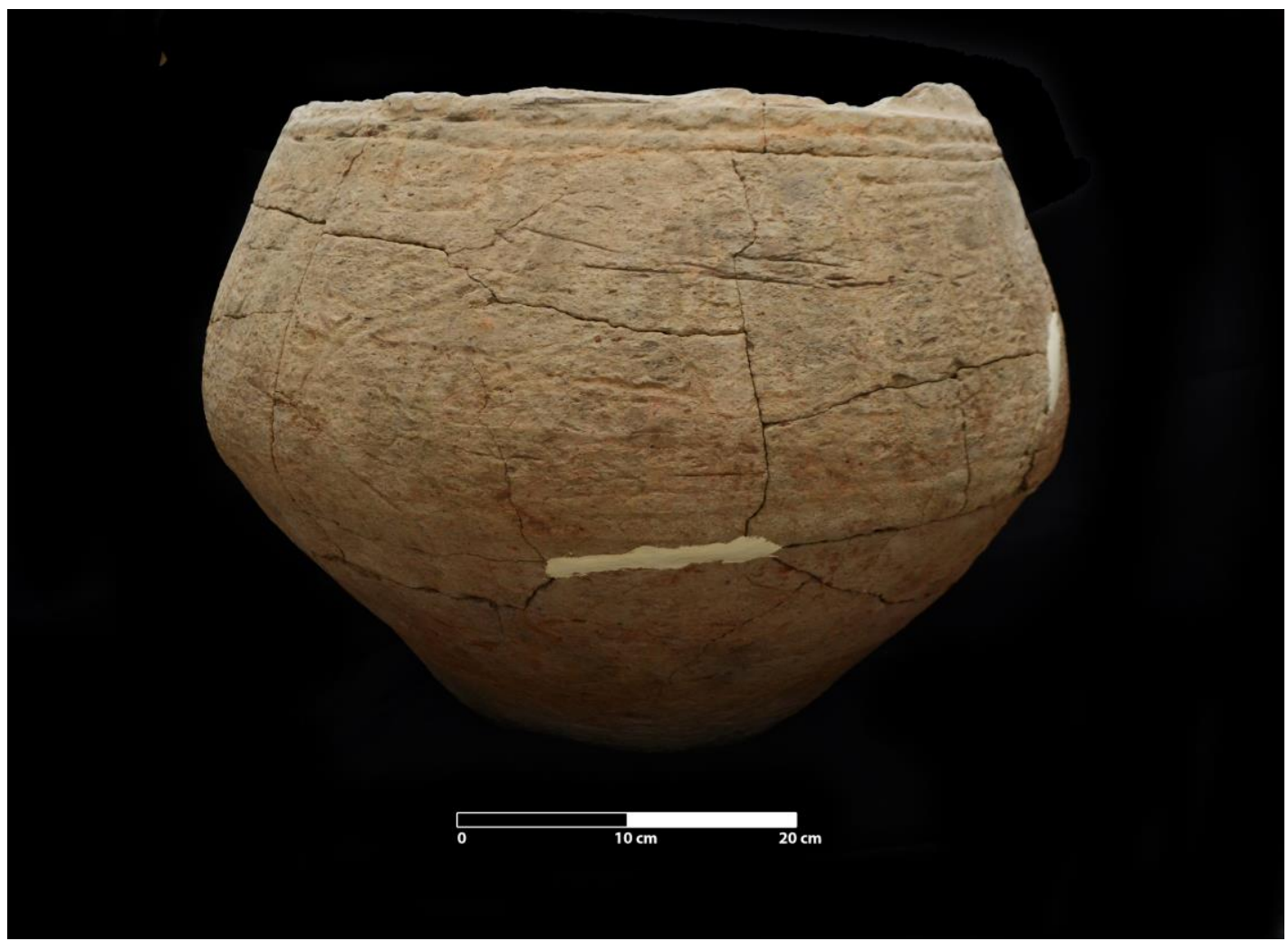

Figura 55: Urna PN 516 após processo de restauração

O vasilhame apresenta pasta composta por caraipé abundante, carvão, cauixi, hematita e quartzo como antiplásticos. A superfície externa apresentava-se muito firável. Há variação da cor do núcleo, mas a maior parte do vaso apresenta queima oxidante incompleta, com a coloração variando de laranja ao acinzentado. A base particularmente, possui o núcleo escurecido.
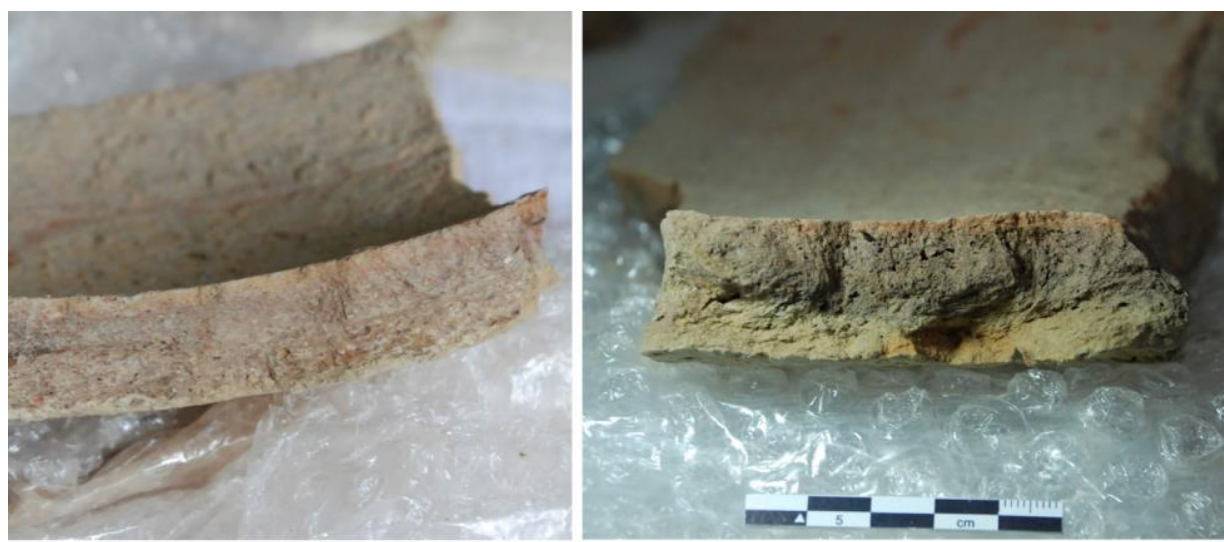

Figura 56: Detalhe dos fragmentos da urna, com fraturas que indicam os roletes.

A técnica de manufatura foi o acordelado, mas sendo possível observar também prováveis aplicações de placas. Isso é interessante, pois pode contribuir para a explicação 
da fragmentação em lâminas da urna, além de condições tafônômicas diversas. A porção inferior do bojo no inicio da base apresenta expessura de $2 \mathrm{~cm}$, enquanto que o bojo e a poção próxima à borda a expessura da parede é de $3 \mathrm{~cm}$ ou mais. Essa variação também contribuiu para diferentes graus de fragmentação da peça, sendo maior na base. A urna no estado atual possui $43 \mathrm{~cm}$ de altura, tem contorno simples, bojo irregular medindo $57 \mathrm{~cm}$ de diâmetro, com restrição da boca que mede $44 \mathrm{~cm}$ de diâmetro e base concova com aproximadamente $15 \mathrm{~cm}$ de diâmetro.

Apesar do péssimo estado de conservação da superfície externa, foi possível observar que a decoração por técnicas plásticas e pintadas. As primeiras são observadas na porção próxima a boca e por todo o bojo, são incisões duplas e acanalados. Há uma linha horizontal ondulada marcando o limite da provável borda (Figura 57 A), o bojo em si, possui linhas escalonadas e diagonais(Figura $57 \mathrm{~B}$ ), que delimitam zonas que recebem diferentes motivos quadrangulares, embora não tenha sido possível distinguí-los bem. O limite do bojo possui pelo menos três linhas horizontais feitas através de incisão com instrumento de ponta dupla, que parece também limitar o campo decorativo do bojo (Figura 57 C). Vestígios de engobo vermelho foram observados apenas na poção inferior do bojo, próxima à base (Figura $57 \mathrm{D}$ ).
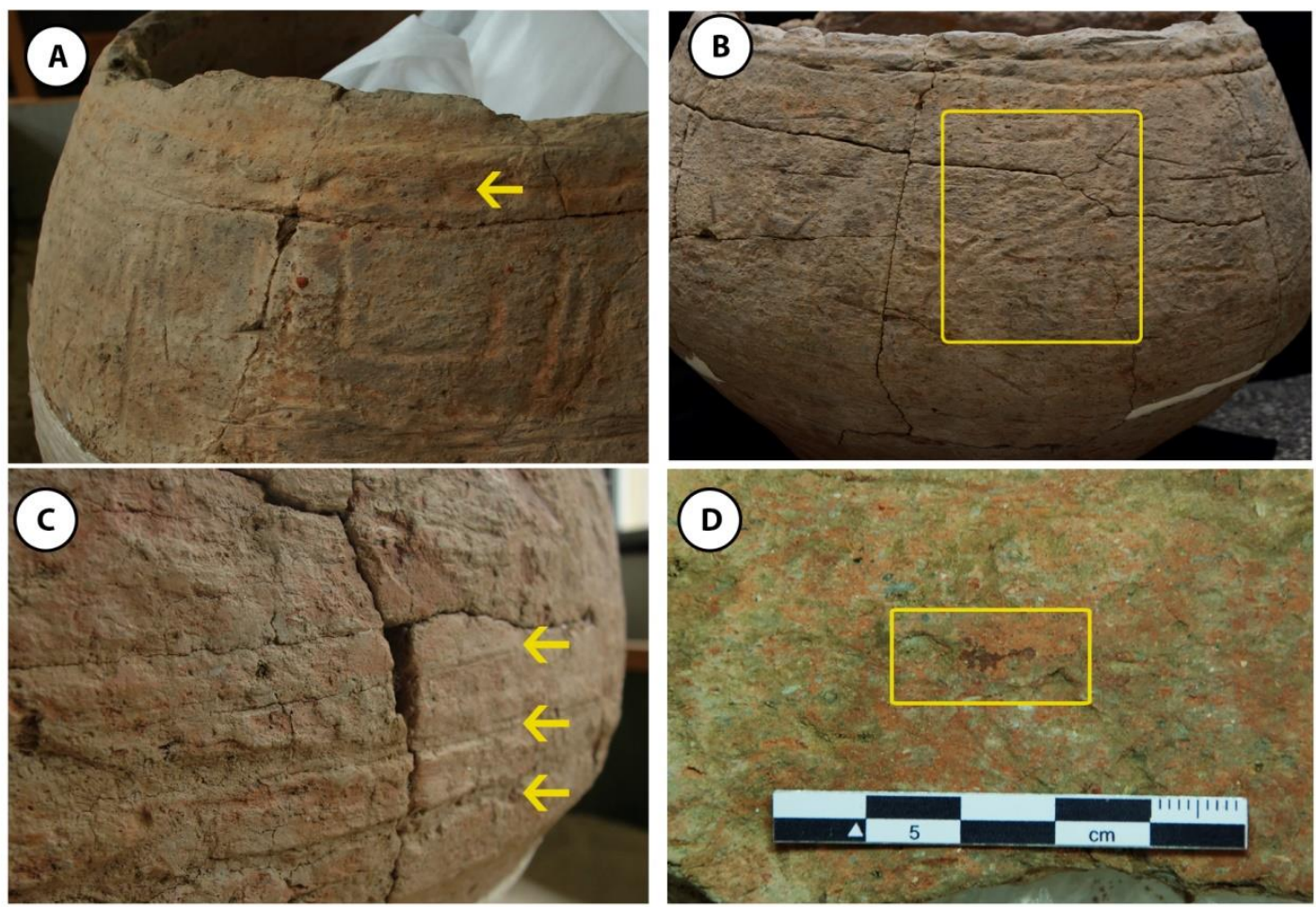

Figura 57: Detalhes da urna 516 


\section{PN 517}

Urna escavada e desmontada em campo, apresentou no seu interior um outro vasilhame (provável tampa). Apenas em 2012 a urna passou por processo de higienização, com limpeza mecânica a seco e apresentou péssimo estado de conservação e alto grau de fragmentação, com mais de 300 fragmentos. Ainda sim, foi possível observar algumas de suas

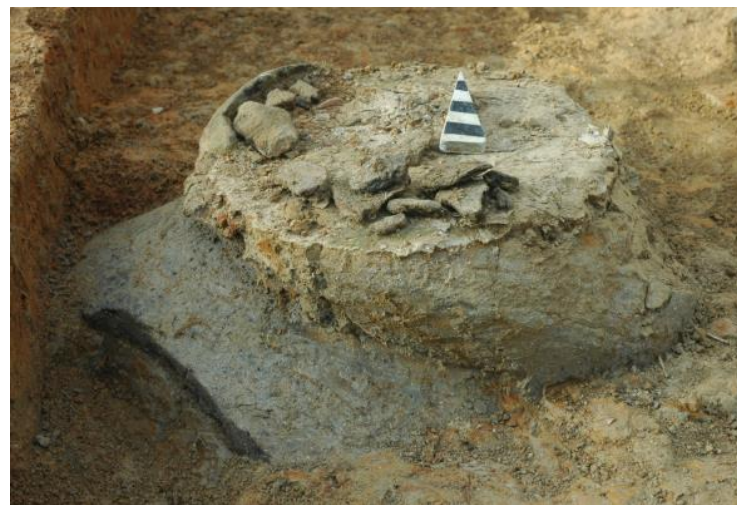

Figura 58: Escavação urna 517. Foto: Bernardo Costa

características tecnológicas. A pasta é composta por caraipé, cauixi, hematita e quartzo, além de nódulos de agila. A superfície apresenta coloração avermelhada, e a queima bastante irregular, sendo incompleta na maior parte dos fragmentos. Embora sem registro da altura total do vaso, a partir de informações de campo, sabemos que possui aproximadamente $44 \mathrm{~cm}$ de diâmetro de borda, cuja inclinação é extrovertida, formato reto e lábios arredondados. O ponto de inflexão forma um curto gargalo, com abertura para o bojo que possui $65 \mathrm{~cm}$ de diâmetro. A decoração observada, foi realizada através de incisões e acanalados, com a delimitação de uma faixa para a aplicação de motivos retilíneos na parte superior do bojo.

PN 518

Urna escavada e desmontada em campo, in situ já apresentava a borda totalmente deteriorada. O estado de conservação é péssimo, e grande medida não apenas pela ação tafônomica de intempéries naturais e culturais, mas tabem pelas próprias características da sua manufatura, que em certa medida, é comparável com a

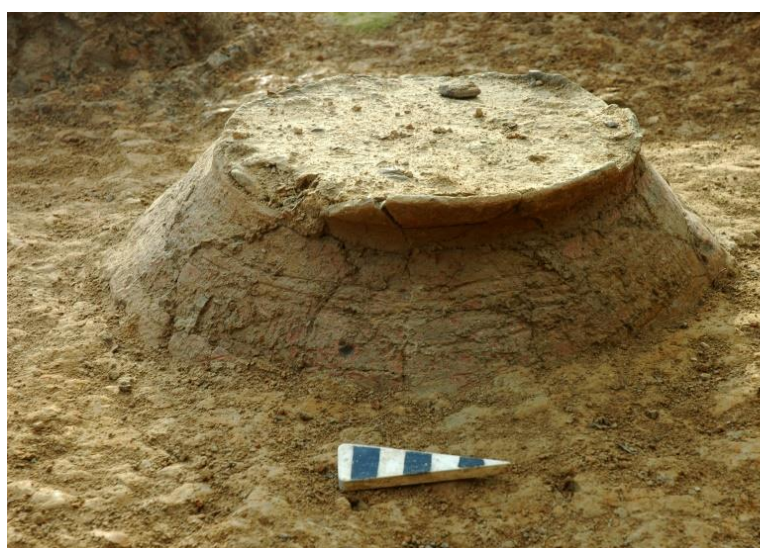

Figura 59: Urna 518 in situ. Foto Bernardo Costa urna 551 do sítio Cacoal do Amanã.

A pasta é extremamente friável, composta por caraipé abundante, cauixi e minerais. O núcleo e a própria superfície interna possuem colorações escuras, acinzentadas, indicando um processo de quiema lento e de baixa temperatura. 
A limpeza a seco foi grosseira, assim como a superfície externa em péssimo estado de conservação, não permitindo obter informação sobre decoração. $\mathrm{Na}$ sua manufatura além do acordelamento é possível detectar a aplicação de placas (Figura x B). Durante seu esvaziamente em campo foi registrada a apresença de lixo recente (plásticos) e ausência de vestígios ósseos, mas durante tratamento em laboratório, em um fragmento foi identificado fragmento ósseo já muito deteriorado (Figura x A). Em termos morfológicos, embora sem inferências sobre a borda é possivel falar de um contorno complexo do vaso, com a formação de um ombro de aproximadamente $52 \mathrm{~cm}$ de diâmetro, e corpo periférico de aprox.. $60 \mathrm{~cm}$ de altura (sem borda).
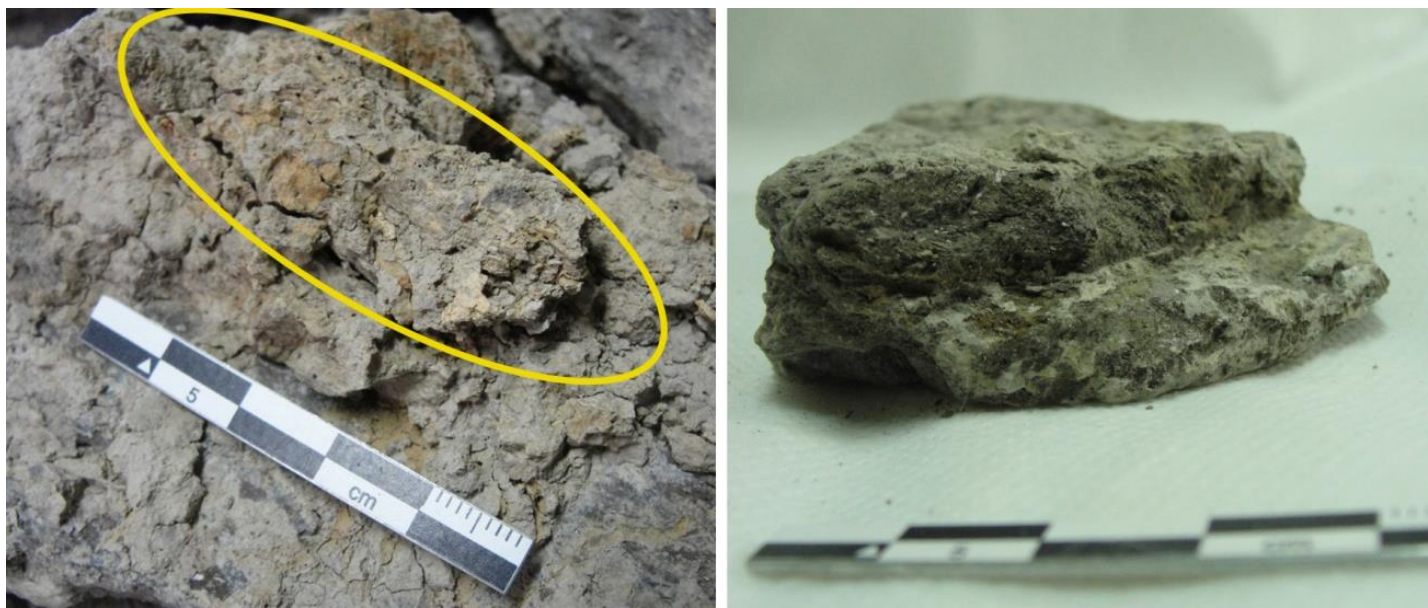

Figura 60: à direita vestígio ósseo e fragmento identificado durante higienização. Esquerda: Detahe de fragmento com junção de placas como técnica de manufatura e coloração escura da

\section{PN 520}

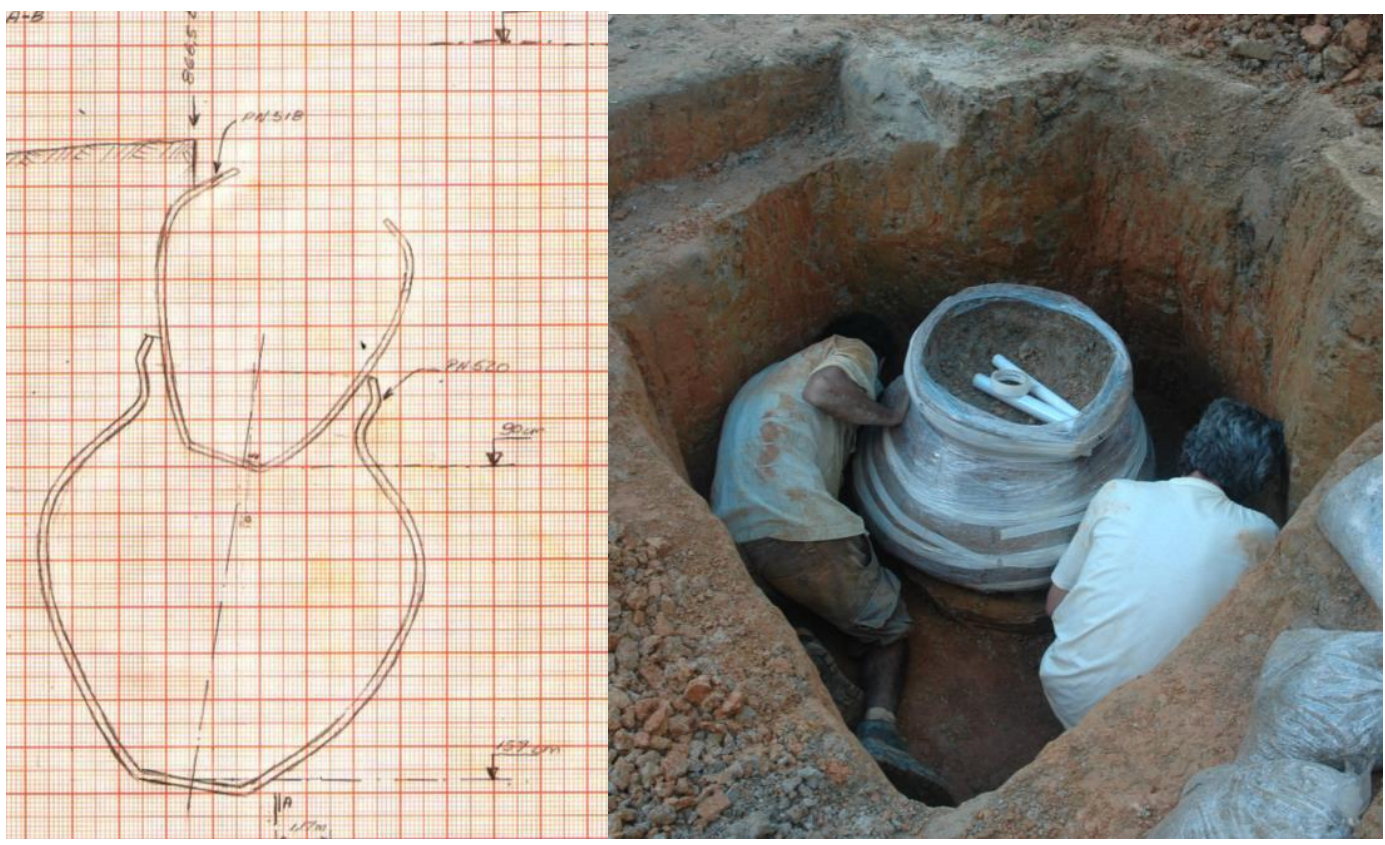

Figura 61 : Direita: Croqui de campo. Marcos Brito. Esquerda: Resgate da urna 520 
Esta urna estava sob a urna 518, com profunidade total para seu enterramento de 1,60 m de profunidade. Seu resgate foi realizado de modo a preservar o contexto fechado para posterior tratamento em laboratório, contudo durante seu transporte sofreu uma queda e teve de ser escavada ainda em campo, não sendo identificado nenhum vestígio ósseo. O vaso possui grandes dimensões, com $90 \mathrm{~cm}$ de altura, aproximadamente $80 \mathrm{~cm}$ de diâmetro do bojo e $50 \mathrm{~cm}$ de borda.

O contorno complexo, pelas inflexões da borda, destaca sua similaridade com urnas típicas da fase Mancapuru, na região de confluência dos rios Negro e Solimões (Lima, 2008). Embora sem datações desses materiais e havendo a possibilidade de ambas as urnas terem sido depositadas em um único evento, a sobreposição das urnas pode também indicar momentos distintos de uso daquele lugar.

A amostragem do sítio Bom Jesus do Baré é composta por 4 urnas, todas elas com morfologias distintas entre si e caracterizando uma variabilidade que pode estar relacionada, não apenas ao "repertório" de formas que seus produtores tinha à disposição, mas também mudanças e transformações ao longo do tempo. Como praticamente todos os vasos possuem antiplásticos vegetais, é possivel aumentar o entendimento do sítio com a datação das próprias cerâmicas.

\subsection{Sítio Cacoal}

Neste sítio foi coletada a Urna PN 551 que estava depositada na base das camadas culturais (Cf Capítulo 3). Ela foi escavada e desmontada silmutanemanete em campo, resultando em 254 fragmentos. Apenas três anos depois, entre 2013 e 2014, esta urna passou por um processo de limpeza com a restauradora Silvia Cunha Lima, visando seu acondicionamento apropriado e conservação. A cerâmica apresentava-se extremamente friável, provavelmente devido à combinação de diversos fatores como a composição da pasta, condição e temperatura de queima do vasilhame e ação do intemperismo durante o período de enterramento e resgate (Lima, 2014).

Diferentes técnicas de manfatua foram usadas na produção do vasilhame, a base parece ter sido feita com a técnica de placas, e o corpo com roletes sobrepostos. A pasta é composta por antiplásticos vegetal (caraipé) em grande proporção, seguido de cauixi e minerais. Somente a camada mais externa da cerâmica apresenta oxidação, sendo o núcleo de coloração escura e de baixa resistência. A coloração da superfície interna é semelhante à coloração observada no núcleo. A preservação da superfície externa, seja nas áreas com decoração polícroma como naquelas com apenas aplicação de engobo, apresenta-se 
extremamente comprometida com acentuado processo de craquelamento e

desprendimento acompanhando o ressecamento da camada de sedimento argiloso aderido.

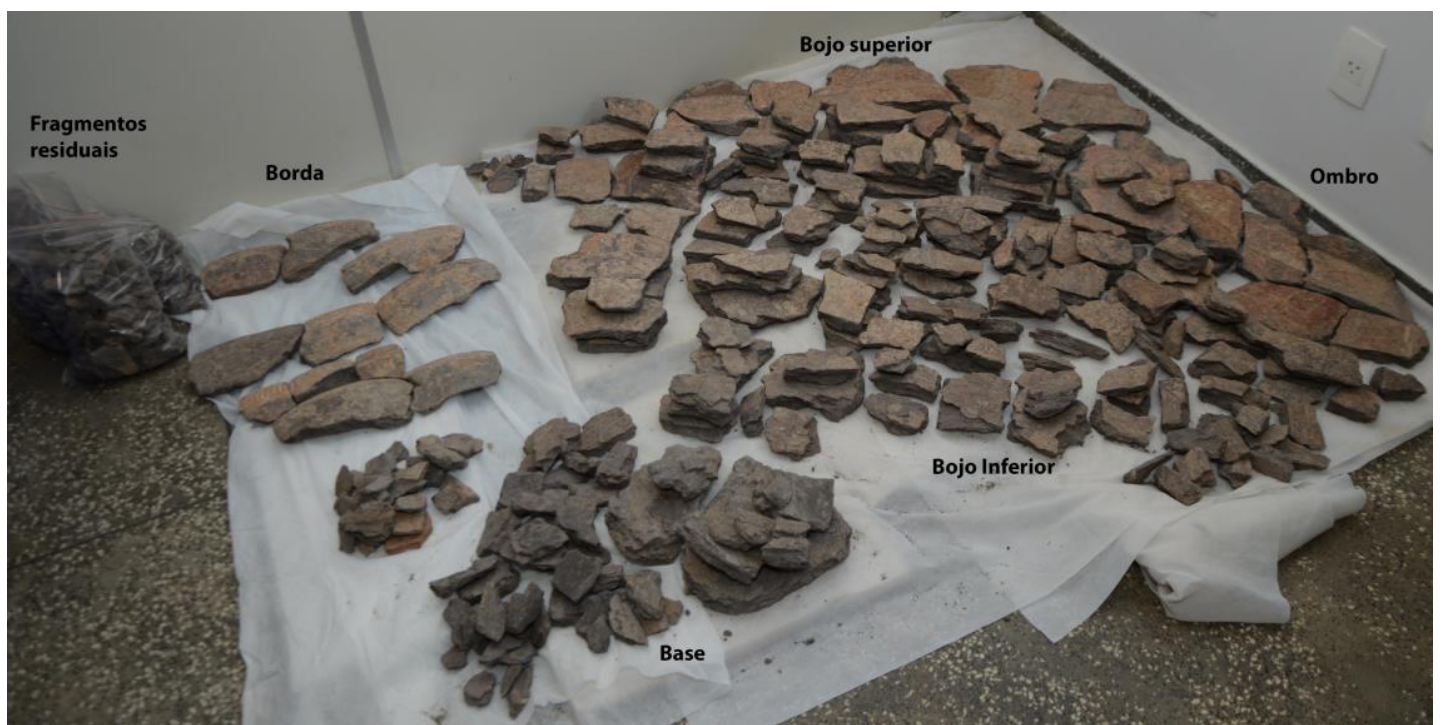

Figura 62 Urna 551 durante processo de higienização e conservação no Laboratório de Arqueologia do IDSM.
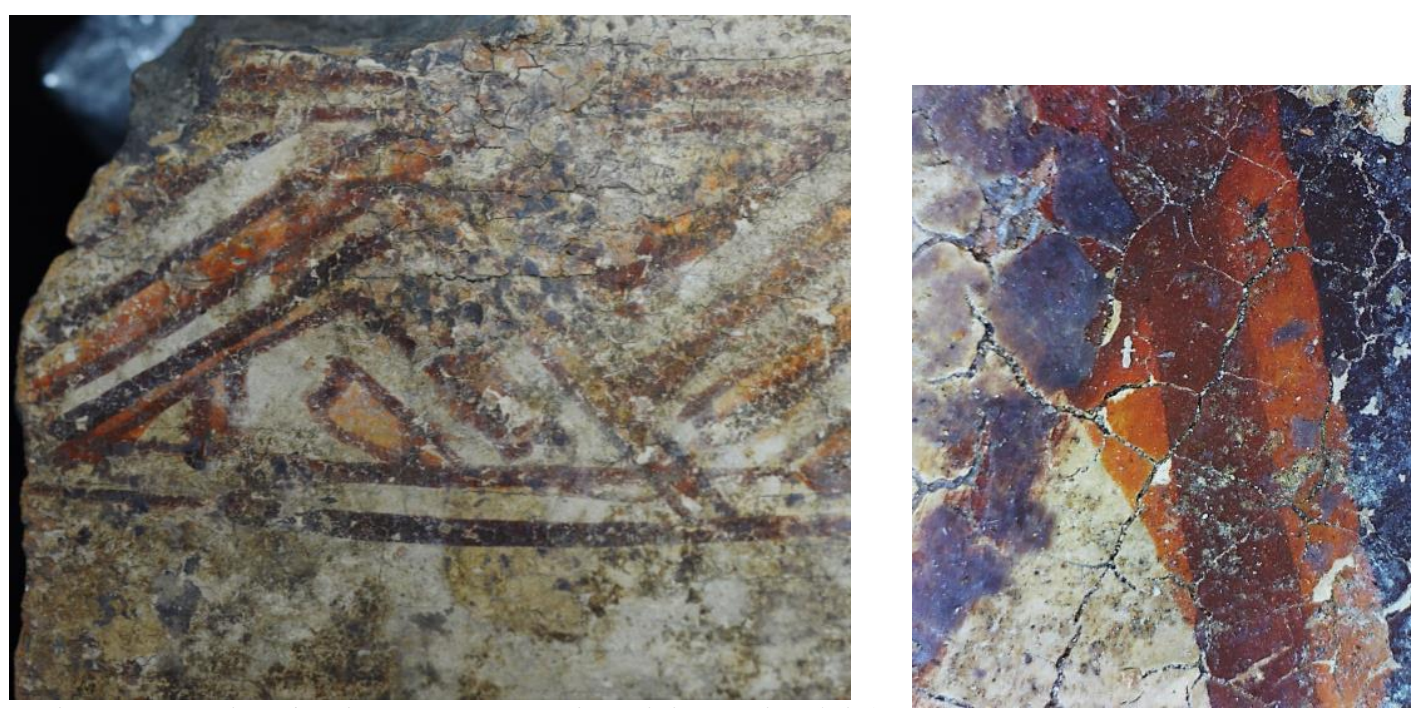

Figura 63: Faixa de pintura com motivo típico Caiambé (Imagem: Jaqueline G); à esquerda, detalhe da policromia em diferentes tons de vermelho e sobreposições (Imagem Silvia Lima).
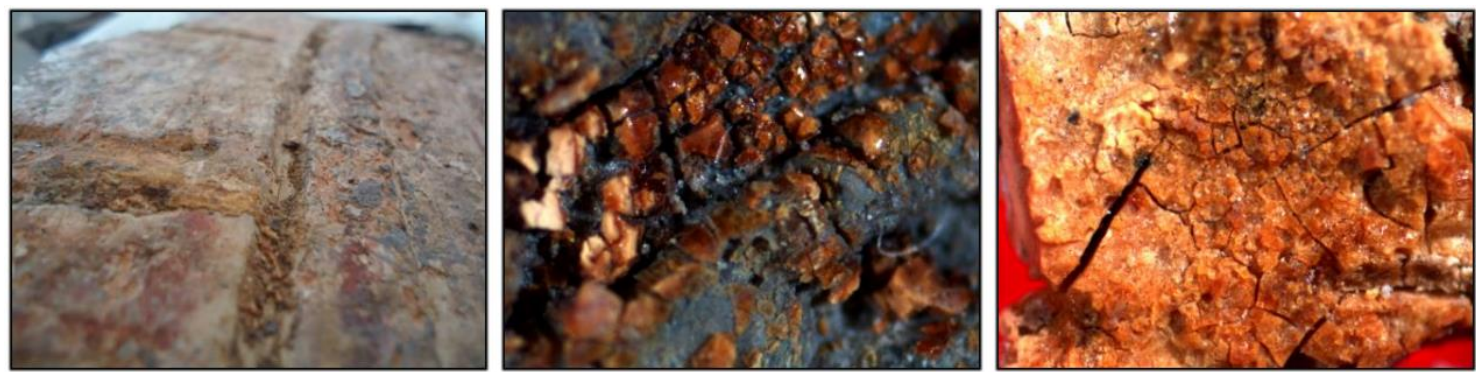

Figura 64: : Detalhes dos vestígios resinosos da urna PN 551 através de lupa binocular 60 x. Imagens: Silvia Cunha Lima. 
Durante o procedimento de limpeza duas características tecnológicas foram observadas. A primeira é a policromia usada na peça, com a utilização de diferentes tonalidades de pigmento mineral - vermelho, vinho e laranja. Ainda que careça de análises mais específicas, tem-se levantado a hipótese que diferentes momentos de execução da pintura e etapas de queima, podem explicar este efeito "polícromo" (Silvia Cunha Lima, comunicação pessoal, 2014).

A segunda técnica bastante singular nesta urna foi observada através de vestígio de substância com aspecto resinoso recobrindo a superfície externa da cerâmica. Amostras foram coletadas e já em processo de analise.

A urna apresenta uma morfologia bastante complexa e singular. No perímetro da borda há dois pontos de inflexão, que se abre formando um largo ombro e bojo que possui um formato elipsóide, em seguida há um afunilamento da base. A decoração aplicada reúne elementos plásticos e pintados. De modo geral há uma base de engobo branco na porção superior, nos ombros e borda, já na porção inferior engobo vermelho (tom de vinho). Acanalados profundos e largos formados por incisões múltiplas, delimitam diferentes campos decorativos. Nos fragmentos da borda foram observadas incisões duplas paralelas verticais, intercaladas com um motivo contrastante em S, sendo replicado na extremidade do ombro. O ombro em si, apresenta uma decoração pintada em diferentes tons de vermelho, vinho e amarelo, cujo motivo é formado por linhas horizontais e diagonais, construindo uma faixa. 


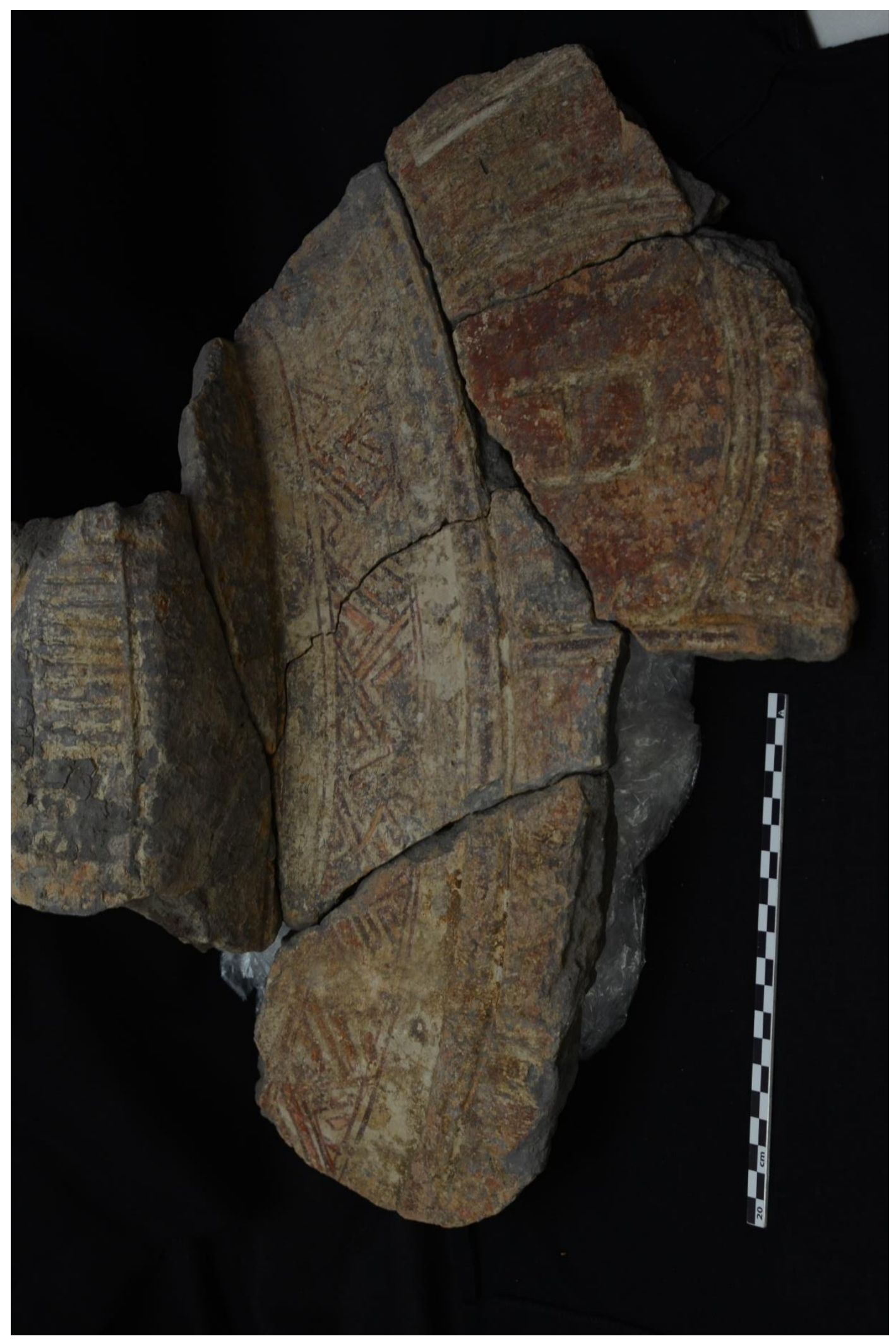

Figura 65: Urna 551 após trabalho de conservação e colagem parcial 
No interior da urna havia um vaso tipo alguidar, encontrado praticamente inteiro que provavelmente teve a função de tampa. Ainda foram coletados poucos fragmentos cerâmicos, que apresentaram um péssimo estado de conservação, com superfícies deterioradas e pastas friáveis, ainda sim é possivel reconhecer aspectos decorativos diagnósticos, como borda extrovertidas incisas com motivo triangular, paredes com incisão dupla e engobo branco com pintura vermelha (Figura 66).
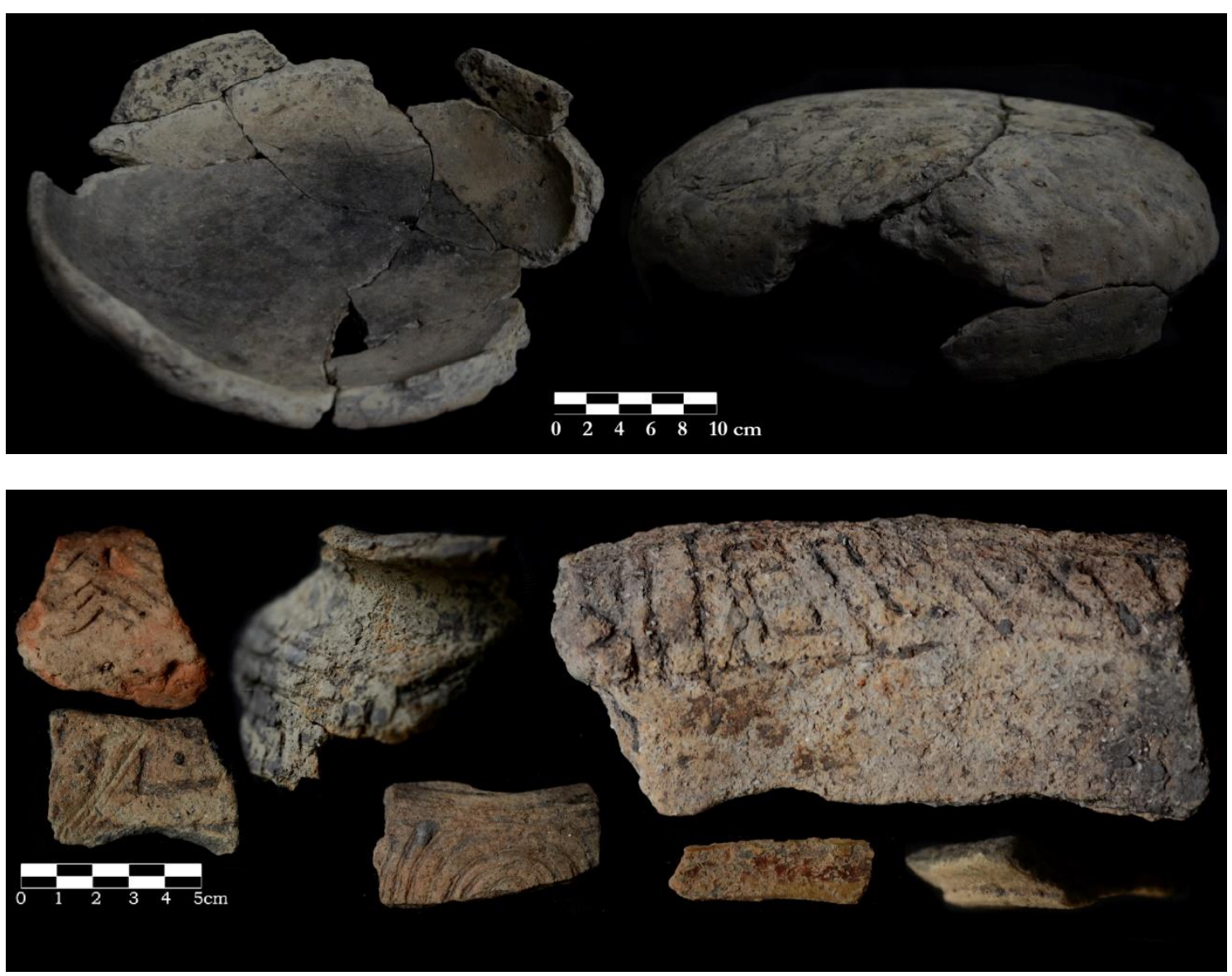

Figura 66: Acima vaso remontado, provável tampa da urna. Abaixo: Fragmentos cerâmicos decorados encontrados no interior da urna, destaque para o péssimo estado de conservação do material.

\subsection{Sítio São Miguel}

Urna PN 572

Aproximadamente 20 dias após sua coleta, a urna 572 foi escavada em laboratório. Já em campo apresentava-se muita fragmentada, mas com seu transporte para o Laboratório do IDSM, em Tefé, e sua exposição ao ambiente

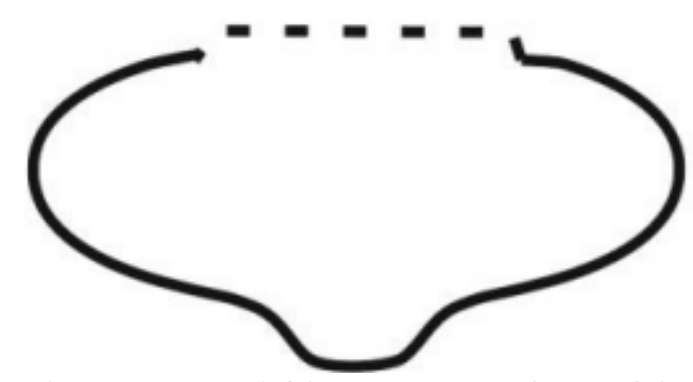

Figura 67 croqui feito em campo da morfologia da urna 572 
instável e quente, esta fragmentação aumentou consideravelmente. A morfologia desta urna é bastante singular, pelas medidas tomadas em campo e sem precisão sobre início da borda, apresenta um bojo elipsoide de $80 \mathrm{~cm}$, uma base cônica de $20 \mathrm{~cm}$, e aprox. $40 \mathrm{~cm}$ de altura. A pasta cerâmica apresenta caraipé como principal antiplástico, a queima é imcompleta e bastante irregular, apresentando em algumas áreas oxidação, mas de modo geral o núcleo é escurecido. A decoração consiste em engobo vermelho, em grande parte já desgastado, não sendo identificada outra camada de pintura, além de acanalados retilíneos.

Por seu grau de fragmentação, optou-se que durante a escavação do seu interior seguiríamos com desmontagem da urna, coletando os fragmentos pelos seguintes setores: borda, parede I/II/III e base. Durante sua escavação as seguintes observações foram realizadas:

Sedimento apresentou coloração 10YR 3/2, textura areno-argilosa e pouca compactação. Bioturbações formadas por radículas e raízes de espessura fina foram observadas, bem como pequenos carvões dispostos de maneira esparsa na parte superior;

$\checkmark$ Durante a escavação do seu interior, ainda próximo do que seria a borda, foi evidenciada uma estatueta cerâmica sem cabeça com marcas de quebra. Ela apresenta traços femininos, com representação de seios e genital. Também possui traços zoomorfos, com uma modelagem em sua parte traseira que sugere ser uma coluna ou trança.

$\checkmark$ No decorrer da escavação foram observadas bioturbações causadas também por formigueiro. Em alguns pontos o sedimento, apesar de pouco compacto, apresenta concreções bem escuras, aparentando ser formadas por ação de queima. Chegando próximo à base da urna foram evidenciadas fragmentos de provável assador.

$\checkmark$ Abaixo destes fragmentos foram evidenciados outros de coloração bem escura, queima redutora e espessura fina, que pôde posteriormente ser reconstituído. Foram observadas quebras recentes e antigas neste vaso, indicando um esmagamento anterior à escavação.

$\checkmark$ Durante o peneiramento do sedimento coletado próximo a base foram coletados dois fragmentos de material ósseo. Também foram evidenciados na escavação outros fragmentos cerâmicos de um vasilhame já na base da urna. Nesta área a ocorrência de carvões aumentou.

A análise dos vestígios ósseos foi realizada por Anne Rapp Py-Daniel (2011; 2013), que identificou como de um indivíduo infantil devido o tamanho, considerando o péssimo estado de conservação dos ossos não foi possível determinar a idade com precisão.

Entre o material cerâmico encontrado na urna, destaca-se a estatueta chocalho (Figura 7) com traços femininos, representação de seios e genital na sua porção frontal, aa superfície dorsal do artefato há uma representação em relevo de uma coluna vertebral (ou 
possivelmente uma trança), ali também foram identificados vestígios de engobo branco. A estatueta possui marcas de quebra no local da cabeça, seus membros inferiores e as nádegas lembram alguns quadrúpedes. A peça possui pasta composta com cauixi, quartzo e hematita, com quiema oxidante e coloração laranja. A presença de fragmentos de um assador também é interessante, pois parece ter tido a função de tampa, além do pequeno prato não decorado com quebras recentes e antigas, indicando um esmagamento anterior à escavação. Por fim, a estueta pode conferir um caráter especial àquele contexto funerário. Levando em consideração as dimensões da própria urna e a ausência de informações no que se refere à coerência anatômica ou de organização do material ósseo infantil identificado, não é possível inferir que se tratava de um sepultamento primário ou se somente os ossos foram sepultados, mas a forma peculiar do vaso e seu conteúdo conferem a todo o conjunto um caráter diferenciado, podendo estar relacionado com a idade - jovem - do indivíduo e/ou sua família e grupo (Costa et al, 2012).
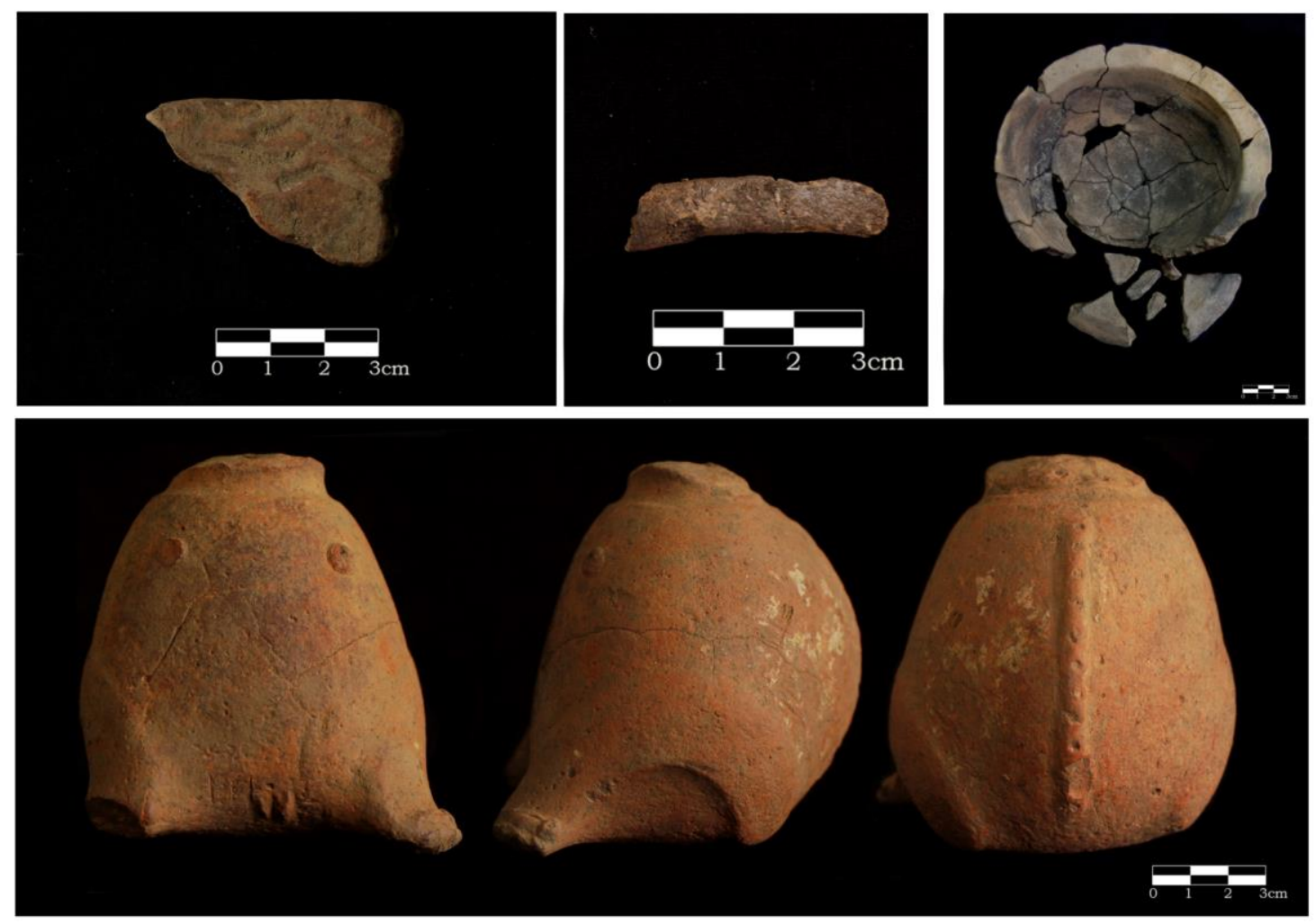

Figura 68: Prancha urna 572 - da esquerda para direita: fragmento de flange labial típico da fase Caimbé; fragmento de costela de provável indivíduo infantil; vasilhame sem decoração depositado na base da urna, repleto de fuligem. Abaixo estatueta-chocalho sem cabeça coletada no inicio das escavações da urna. 


\section{Urna PN 573}

A urna 573 foi escavada concomitante a 572, possui uma morfologia periforme, típica da Tradição Borda Incisa, suas medidas tomadas em campo são aproximadamente $60 \mathrm{~cm}$ de altura, 64 $\mathrm{cm}$ de diâmetro do bojo, $30 \mathrm{~cm}$ de borda e base de $20 \mathrm{~cm}$. Esta urna apresentou-se mais conservada, embora também apresentando quebras antigas. A desmontagem da urna seguiu, na medida do possível, suas partes estruturais (borda, bojo parede superior e inferior - e base).

Foram observados vestígios de pintura vermelha sobre engobo branco na porção inferior ao bojo. O bojo é decorado com incisões duplas retilíneas que formam motivos quadrangulares, enquanto que na porção superior da urna em superfície já bastante desgastada, identificamos através da lupa vestígios de pintura e engobo em alguns fragmentos. $\mathrm{Na}$ pasta foi observada presença abundante de cauixi e minerais (hematita e pequenos grãos de quartzo) e a queima mostrouse bastante regular e completa. A espessura da peça varia entre 1,5 e $2 \mathrm{~cm}$, seu contorno é
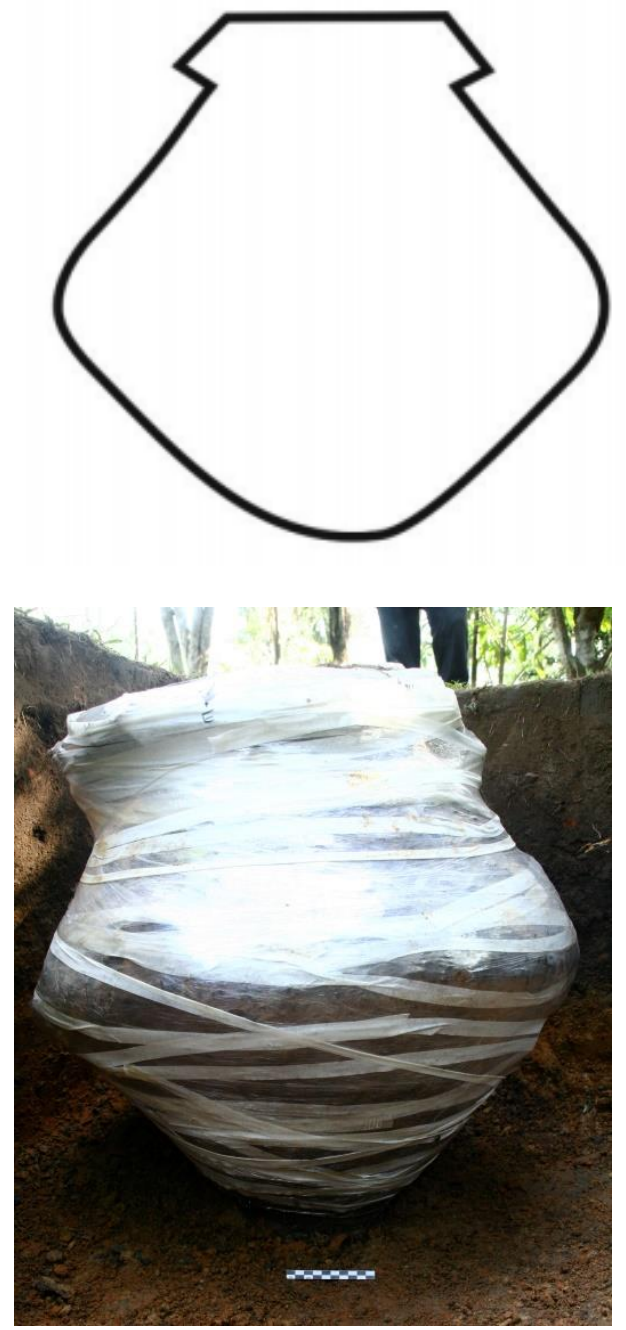

Figura 69: Acima croqui feito durante escavação, abaixo a urna embalada para ser coletada inteira.

complexo, possuindo borda introvertida. No interior do vaso foi encontrado um grande fragmento de assador, além de vários fragmentos basicamente sem decoração que não ultrapassam $6 \mathrm{~cm}$ de comprimento. De todo o material apenas uma borda é diagnóstica, com extroversão tipo flange e lábio serrilhado com decoração típica da fase Caiambé (Figura 70). Durante as escavações em laboratório as observações registradas foram as seguintes:

$\checkmark$ Nos primeiros centímetros o solo interno era de textura argilo-arenosae e coloração 10YR5/4 (yellowish Brown), apresentando radículas e poucos fragmentos cerâmicos.

$\checkmark$ Por volta do início do bojo o solo apresenta uma coloração mais escura e é menos compactado, são observadas raízes menores e bioturbações, a quantidade de fragmentos 
cerâmicos aumenta um pouco, sendo coletados alguns fragmentos de assadores, presença de carvões e pequenas bolotas de argila, na peneira foi coletado um pequeno fragmento ósseo (inicialmente categorizado como "fauna").

$\checkmark \mathrm{Na}$ altura da "parede inferior" são observadas manchas de latossolo, fragmentos de assadores no sentido vertical e áreas com sedimento bem compactado e acinzentado (processos de queima?).
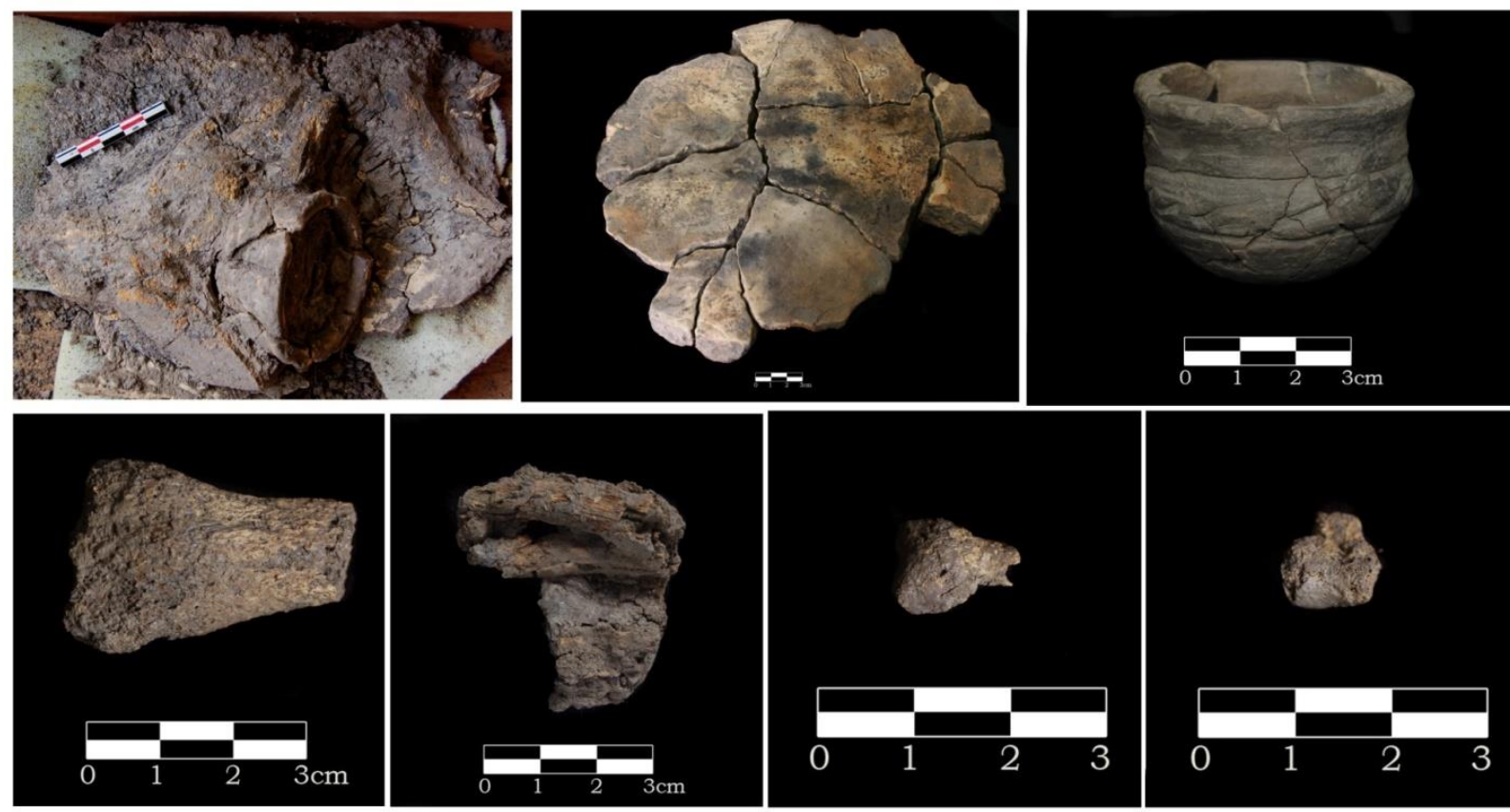

Figura 70: Prancha urna 573 - começando pela esquerda: estrutura funerária retirada em bloco da base da urna; fragmentos de assador provavelmente usado como tampa; miniatura encontrada na estrutura funeraria, já remontada, onde é possível observar uma faixa com decoração típica da fase Caiambé.

Conforme a escavação foi chegando perto da base da urna foram identificados uma concentração de vestígios ósseos na porção NE, juntos a fragmentos cerâmicos. Ao serem mais evidenciados percebeu-se que se tratava de um pequeno vasilhame com borda de aprox. $8 \mathrm{~cm}$ de diâmetro, próximo a ele, foram identificados mais ossos. A esta altura o sedimento se apresentava mais escuro e mais úmido, apresentando muitos carvões. A partir desse momento foi tratado como uma estrutura funerária .

$\checkmark$ Assim procedemos com a desmontagem da urna seguindo na medida do possível a coleta por partes. Depois de desmontada a urna foi retirada em bloco a estrutura funerária e armazenada em uma caixa de madeira.

$\checkmark$ No fundo da urna havia um sedimento mais claro, tabatinga (7.5YR 7/1 light gray)

$\checkmark$ Após procedimentos de limpeza de todas as peças a urna apresenta vestígios de pintura vermelha sobre engobo branco na mesma porção inferior ao bojo, o bojo é decorado com incisões retilíneas que formam motivos quadrangulares, na porção superior da urna 
a superfície encontra-se muito desgastada - não foi observado nenhum vestígio de decoração.

As peças provenientes do interior do recipiente também foram lavadas e triadas, o material consiste basicamente em fragmentos sem decoração que não ultrapassavam 6 $\mathrm{cm}$ de comprimento.

Segundo Py-Daniel (2011), a partir da escavação do bloco, o material ósseo identificado pertence a pelo menos 1 (um) indivíduo, e embora o estado de conservação seja péssimo, algumas partes do cortical e do osso esponjoso estavam preservadas. Isso permitiu inferir a idade adulta ou adolescente do indivíduo, mas o tamanho dos ossos é muito reduzido. Sobre a disposição do sepultamento a pesquisadora pontuou:

não é possível saber se os ossos estavam dispostos com alguma lógica de organização ou se havia coerência anatômica, mas é interessante notar que há ossos pequenos presentes (extremidade distal de falange proximal) e que num pequeno bloco (PN 573.53) havia ao menos três costelas associadas. O crânio estava no fundo do vaso, todos os ossos estavam por cima ou ao lado. $\mathrm{O}$ vaso tem $60 \mathrm{~cm}$ de diâmetro, esse tamanho permite vislumbrar a presença de um indivíduo pequeno articulado ou desarticulado no seu interior (Costa et al, 2012: 78).

As urnas 572 e 573 apresentam em seu interior fragmentos cerâmicos de vasilhames distintos, que não parecem ter sido depositados em seu interior. Desde as suas bordas encontram-se material de pequenas dimensões que provavelmente estavam presentes no sedimento do entorno quando este preencheu o interior dos vasos enterrados na mancha de terra preta localizada na porção leste do sítio (Costa et al, 2012). No entanto, na urna PN 572, maior quantidade de material cerâmico externo foi observada, enquanto que na urna 573 o material cerâmico foi mais frequente apenas acima do assador encontrado na altura do bojo da urna. Sugerimos que o assador tenha sido usado como uma tampa, isolando o contexto funerário encontrado. Esta urna teve o maior número de ossos preservados e apresentava um sedimento mais claro.

Também é interessante o pequeno vaso encontrado acompanhando o sepultamento (PN 573,63- Figura 17). O sedimento que estava no seu interior, por observações macroscópicas apresentava-se muito compactado e pequenas concreções bastante escuras. Quando flotado não foram encontrados materiais carbonizados que pudessem ser amostrados para datações. Uma hipótese para explicar essas características é que no processo de decomposição do corpo, há a liberação de gorduras e líquidos ácidos que podem alterar a composição do conteúdo do vaso (Veronica Wesolowski, 2014, 
comunicação pessoal). O sedimento foi amostrado para diferentes análises (química, lipídio e microvestígios) que poderão ajudar no entendimento desse contexto.

A urna PN 572 tinha em seu interior fragmentos de um assador, que pode ter sido usado como uma tampa, um prato depositado na sua base e uma estatueta chocalho, que conjuga características zoomórfica e antropomórfica, e pode conferir um caráter especial àquele contexto.Nesses dois casos, as urnas são contextos funerários que apresentam pelo menos três elementos comuns, além do contexto de deposição, cujo enterramento foi em área de terra preta: 1) assadores podem ter sido usados como tampas, devido à localização deles no interior dos vasos, na altura do bojo; 2) há material cerâmico acompanhando os corpos, nos dois casos, vasos depositados na base das urnas; 3) nos dois casos, os elementos ósseos não apresentaram vestígios de queima. Na urna 573 há possibilidade do individuo ter sido depositado com os ossos articulados, devido a observação de costelas associadas durante a escavação do bloco. Esta observação é interessante porque abre perspectivas para um sepultamento primário, algo observado no sítio Bom Jesus do Baré.

\section{Urna PN 685}

Já a urna PN 685 apresenta um contexto distinto, começando pelo próprio espaço usado para sua deposição, em uma área fora da terra preta, próximo à margem d'água. $\mathrm{O}$ recipiente foi escavado e desmontado in situ, passando posteriormente por uma etapa de limpeza a seco. Entre 2012 e 2013 passou por duas etapas de restauração (Lima, 2012 e 2013), cujo estado de fragmentação era de 190 unidades, e dezenas de lascas ou fragmentos de dimensões diminutas. Trata-se de um vaso de grandes dimensões, com 1,20 m de diâmetro de bojo, $56 \mathrm{~cm}$ de borda e aproximadamente $80 \mathrm{~cm}$ de altura. A morfologia de contorno complexo, com borda introvertida e pescoço constrito, bojo elíptico e base plana. Esta morfologia é muito característica das urnas da fase Manacapuru identificados nos sítios Hatahara e Paricatuba na área de conlfuencia do Negro e Solimões (Lima, 2008; Tamanaha, 2012), e também de vasos da fase Pocó do sítio Boa Vista, no baixo Amazonas (Guapindaia e Lopes, 2012). Todo o bojo é decorado através de acanalados duplos, com motivos retangulares que se repetem através dos movimentos de translação com rotação, em subcampos decorativos delimitados por faixas acanaladas sinuosas. 

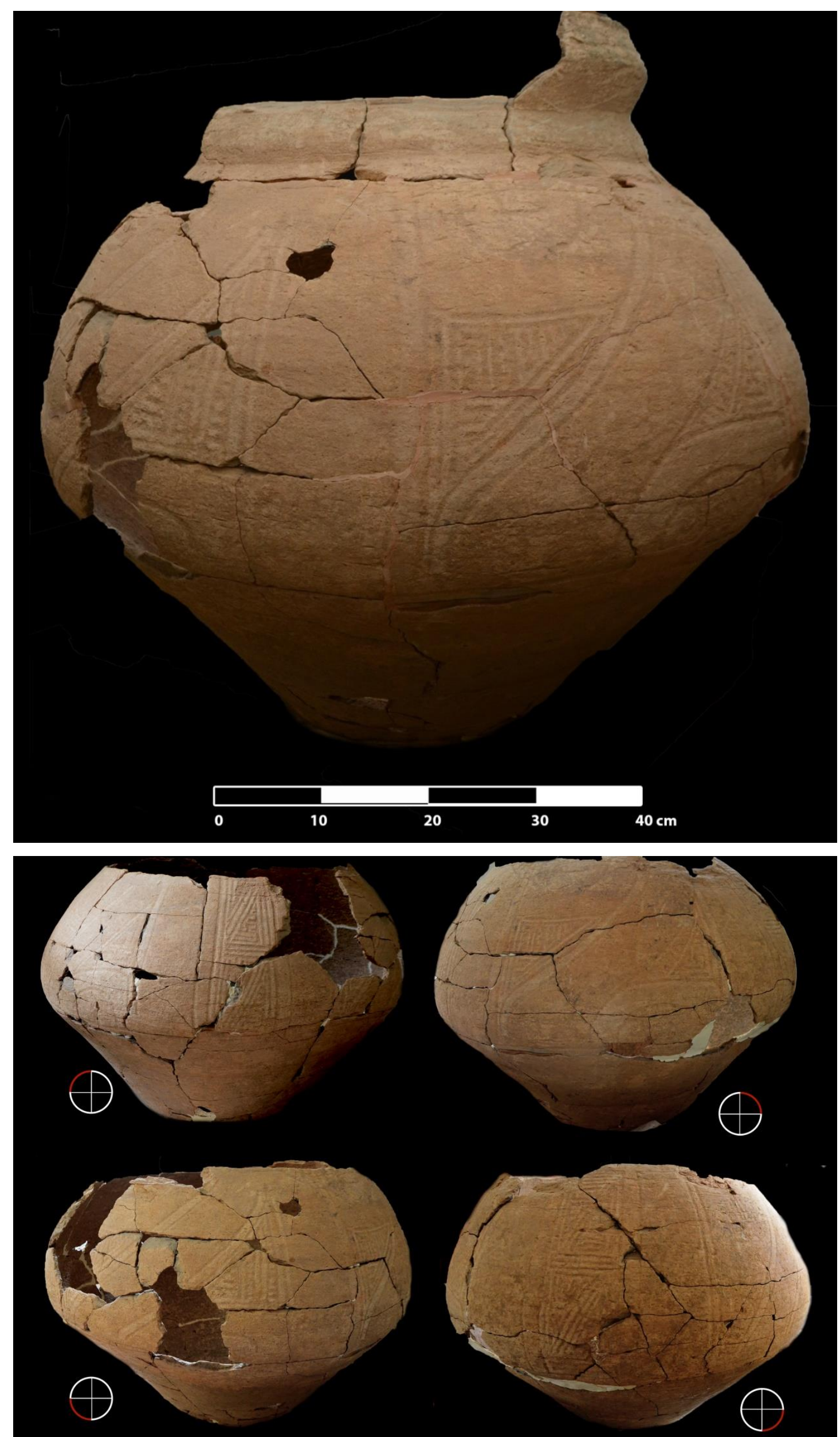
A pasta cerâmica é composta por antiplásticos minerais, caraipé e cauixi, muito friável e com diferentes graus de conservação. A região da borda sofreu biodeterioração (provavelmente líquen) devido ao seu afloramento à superfície, mas observou-se que a base e metade inferior do bojo é região o vaso que apresenta processos de degradação mais acentuados: i) pulverização da pasta cerâmica; ii) desplacamento/ desfolhamento do corpo cerâmico paralelo à superfície; iii) maior quantidade de fissuras horizontais, seguindo à orientação dos roletes de confecção do vasilhame; e iv) acentuada fragmentação (Lima, 2013).

Há grande variação da qualidade da queima, cuja base e metade inferior do bojo apresentam quiema incompleta de núcleo enegrecido, enquanto que o restante do vaso embora apresente núcleo de coloração variável, tende à maior uniformidade. È comum que recipientes de grandes dimensões apresentem heterogeneidades, com diferentes níveis de queima, que obviamente influenciam sobre o estado de conservação. Essas diferenças entre porções superiores e inferiores do vaso são observadas também em relação à eroção das superfícies. A superfície interna na base possui um processo de erosão mais acentuado, o que não ocorre na área próxima à borda, que apresenta ao contrário maior eroção na superfície externa (Lima, 2014). Isso nos leva a pensar que essas diferenças podem se relacionar não apenas a fatores tafonômicos e pós-deposicionais, mas ao própio uso do recipiente, visto que marcas do tipo podem ser resultado de processos químicos durante a fermentação de sólidos ou liquidos (Skibo e Schiffer, 2008; Neumam, 2008 e Lima, 2014).
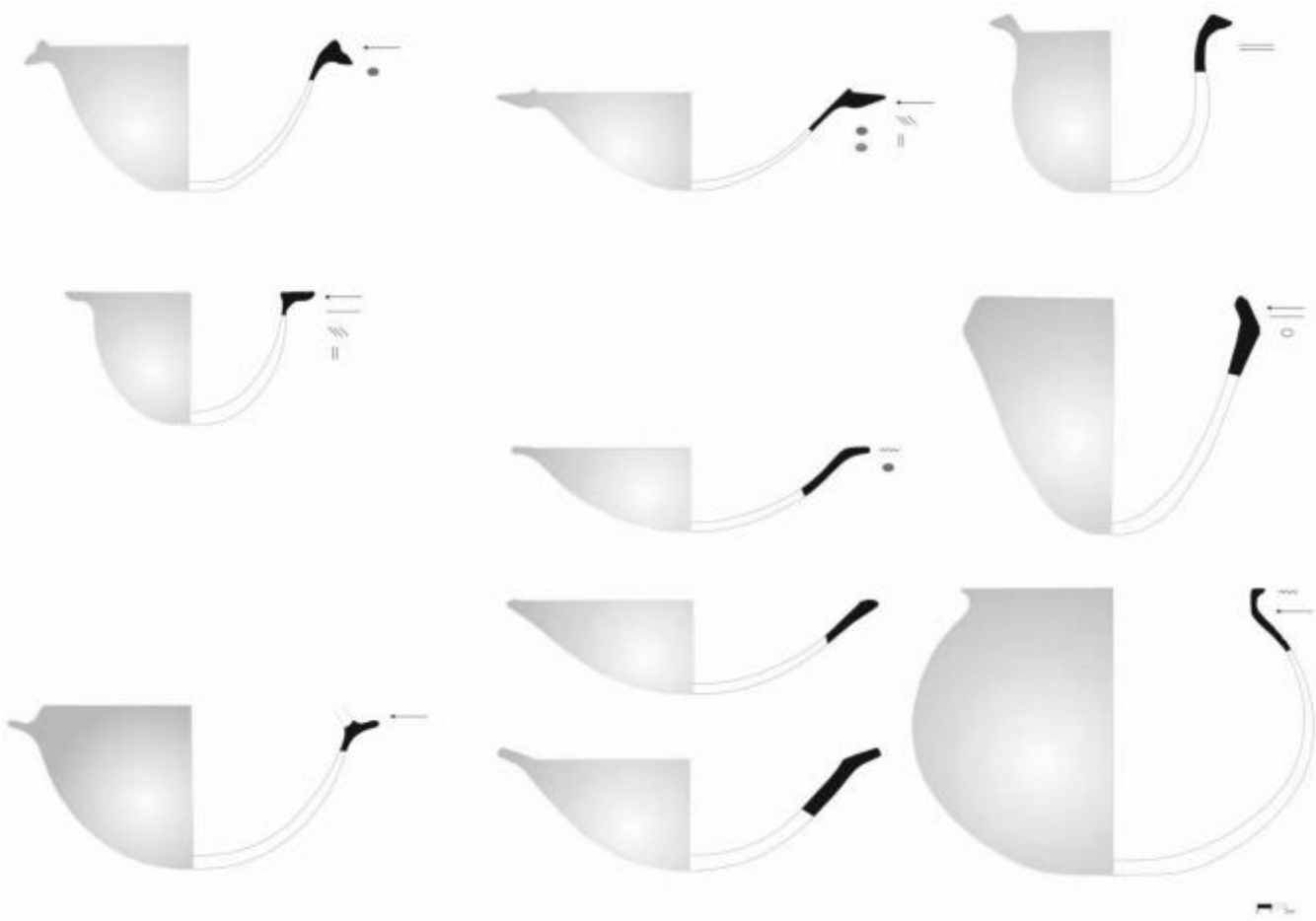

Figura 71: Morfologias reconstituídas do material cerâmico coletado no interior da urna 685. Desenho: Laura Furquim 
Apesar da ausência de vestígios ósseos o conteúdo da urna é interessante, os fragmentos cerâmicos encontrados no seu interior são grandes e diagnósticos, muitos deles decorados e parcialmente remontáveis (Figura X - capítulo 4), o que leva a crer que a deposição deles no seu interior foi intencional. Furquim, em sua análise reconstituiu 10 morfologias, sendo interessante que 6 delas são de vasos irrestritivos apropriados para servir, além do único exemplas de um vaso com flange mesial.

Por fim, embora um grande fragmento de assador tenha sido encontrado, ele estava na base do vaso, que apresentava um sedimento escuro, que, ao que tudo indica não percolou do entorno, mas parece ter sido formado em seu próprio interior. Durante a escavação em campo, o registro do sedimento destaca sua coloração escura (10 YR 3/4) a presença de bolotas de argila, grande quantidade de carvões, tabatinga e latossolo queimado, uma composição bastante semelhante às estruturas que chamamos de feições, identificadas nas unidades de escavações das áreas de habitação. O que nos parece importante salientar é o caráter ritual que este vaso pode estar relacionado.

4. As cerâmicas da fase Caiambé no lago Amanã

As cerâmicas da fase Caiambé apresentam grande variação na composição das pastas, com diferentes misturas de cinco principais antiplásticos: caraipé (licania ssp), cauixi (filo Porifera), minerais (grãos de quartzo e hematita), nódulos de argila e carvão. Quantitativamente as pastas com cauixi é predominante, geralmente são mais uniformes, compactas e menos friáveis. São cerâmicas queimadas em ambiente oxidante resultando em queimas completas. Nas pastas com caraipé a cerâmica geralmente é mais friável, a queima raramente é completa, apresentando maior variação da coloração dos núcleos. No sítio Cacoal, chama atenção a quantidade de caraipé que é adicionada, às vezes tão abundante que pode ser visto a olho nu, com processamento grosseiro, ocorrendo negativos das partículas de caraipé na superfície do fragmento. A variabilidade é vislumbrada pela ocorrência e associação dos antiplásticos, nos leva a pensar que as distintas pastas estão mais relacionadas às performances dos vasos, do que necessariamente um índice de diferenciação cultural.

A principal técnica de manufatura é o roletado, mas nas bordas, apliques e estatuetas o modelado é geralmente usado. Há ainda a combinação de diferentes técnicas na produção de uma parte do vaso, sendo as bases produzidas através de roletes ou placas moldadas em apoio coberto de folhas, que imprimem suas formas na superfície externa das 
bases. As urnas analisadas apresentam paredes espessas, nas quais foram observadas combinações de rolete e placas na manufatura do bojo.

Entre os tratamentos de superfície, o alisamento é a principal técnica, seguida do polimento. $\mathrm{O}$ alisamento é bastante fino, sendo raro observar estrias ou irregularidades das junções de roletes, ou até mesmo direções e movimentos que indiquem gestos. O estado de conservação da superfície dos fragmentos variou de forma expressiva, sendo provável que o polimento tenha sido mais frequente. O escovado ocorre nas paredes, mas não é significativo quando considerado quantitativamente. Outros acabamentos como enegrecimento são raros, ocorrendo em ambas faces dos vasos.

O engobo foi considerado como um aspecto decorativo nesta análise. Sua ocorrência é muito frequente, seja na cor branca ou em diferentes tons de vermelho. Parece haver uma distinção entre o engobo branco nas cerâmicas Caiambé e Tefé, enquanto nas últimas, o engobo geralmente é aplicado em camadas espessas e possui uma textura bastante lisa - e tem diferentes níveis de conservação, apresentando desgaste e menor grau de craquelamento - nas cerâmicas Caiambé, percebe-se o uso menos padronizado, sendo aplicado em camadas de diferentes espessuras, e frequentemente, com péssimo estado de conservação. Isto é interessante, pois trata-se de possíveis técnicas distintas de produção e aplicação do engobo, que se identificadas e melhor caracterizadas através de análises arqueométricas, podem contribuir para melhor diferenciação das cerâmicas Caiambé e Tefé. Corroborando as observações de Hilbert (1698), o engobo vermelho ocorre muitas vezes desgastado e em manchas, cujos vestígios estão na superfície externa do vaso, raramente em ambas as superfícies de paredes e bases.

Em nossas análises, constatamos o predomínio do engobo branco sobre o vermelho (Gomes, 2012; Furquim, 2014), o que é bastante particular das coleções do lago Amanã, primeiro porque nas cerâmicas analisadas por Hilbert sua ocorrência se restringe associada à pintura vermelha no tipo Caiambé policromo, sendo também pouquíssimo relevante em outras fases da tradição Borda Incisa na Amazônia Central. Por fim, embora o engobo seja um elemento definidor de um tipo na classificação inicial da fase, ocorre nas cerâmicas Caiambé o mesmo já observado por Lima e Neves (2011) nas cerâmicas da fase Manacapuru: o engobo na grande maioria das vezes está associado a outras técnicas decorativas, raramente sendo exclusivo em um fragmento. A observação microscópica de todos os fragmentos permitiu identificar de forma frequente vestígios de engobo e/ou pintura dentro de sulcos da superfície decorada - incisões simples e duplas ou acanalados -, sendo comum a aplicação de técnicas plásticas e pintadas em um mesmo projeto decorativo. 
De modo geral o uso da pintura é relevante e significativo, seja através da monocromia, bicocromia ou policromia. A bicromia, via de regra, é executada na cor vermelha - e raramente em preto - em um fundo de engobo branco que pode variar de um tom de cinza ao amarelado. Podem ser identificadas linhas largas e finas, raramente detalhes específicos. A policromia sempre que foi identificada, foi realizada exclusivamente em diferentes tons de vermelho, variando do vinho ao alaranjado.

Para a identificação das técnicas plásticas de decoração foram considerados os gestos e instrumentos utilizados na execução do projeto decorativo. Oito técnicas foram observadas no sítio Cacoal e seis no sítio São Miguel. As predominantes são incisões simples, duplas ou múltiplas e os acanalados, que podem ser aplicadas sozinhas ou combinadas. Em menor escala são observados ponteados ou estocados, digitado/ungulado, modelado e aplicações de esfera e rolete. O uso dessas técnicas é bastante tímido, enquanto a incisão e acanalado são técnicas preferenciais, que ocorrem predominantemente sozinhas e com um leque pequeno de combinações.

Os elementos gráficos mais comuns na decoração são linhas retas únicas e paralelas horizontais, verticais e diagonais; linhas escalonadas; espirais retangulares, linhas onduladas, linhas em ziguezague e curvas (ondas). Essas linhas podem variar de 1 a $5 \mathrm{~mm}$ de espessura a depender da técnica usada, se incisão simples ou com instrumento de ponta dupla.

Um motivo típico é formado por linhas paralelas diagonais de $2-4 \mathrm{~cm}$ de comprimento, que em suas extremidades são adicionadas linhas curtas para a esquerda ou direita. Estas linhas curtas também podem ser usadas para preencher os campos vazios entre linhas diagonais. Há certa variação de como tais combinações de elementos são feitas, formando dessa maneira, motivos distintos que são repetidos e mesclados com outros menores (retângulos, pontos, linhas curtas).

Embora o repertório gráfico seja muito rico, mesclando diferentes graus de linearidade que vai do retilíneo ao curvilíneo, a decoração possui uma estrutura bastante rígida: linhas horizontais delimitam o campo onde os elementos aplicados são repetidos frequentemente no eixo horizontal de simetria, formando padrões unidimensionais em banda ou faixa (Shepard 1956; Washburn e Crowe, 1988). Os movimentos de translação e reflexão com translação são os mais usados, assim como a rotação.

Em termos morfológicos, há uma tendência às morfologias irrestritivas, com evidente variabilidade de pratos, sendo diagnósticas aquelas com flanges labiais e bordas extrovertidas expandidas. Em alguns vasos as bordas para formação desses flanges possuem fortes inflexões. Essas bordas e flanges apresentam certa variação no acabamento 
dos lábios, mas uma característica particular é o recorte e modelagem dos lábios, que formam bordas irregulares, algo já pontuado por Hilbert (1968: 147).

Diferentes formas rasas, conhecidas como assadores que apresentam grandes espessuras e variam muito em dimensões, são muito representativas. No sítio Cacoal, foi identificado um ralador, que parece ser, até o momento, o único fragmento desse tipo de artefato encontrado no Solimões-Amazonas. As morfologias restritivas englobam vasos de contorno simples, composto e complexo. Geralmente estes vasos apresentam como campo decorativo a porção superior do bojo. Os vasos de contorno complexo apresentam pelo menos duas inflexões entre o bojo e o lábio, formando vasos com gargalo carenado, típicos da tradição Borda Incisa, mas os exemplares encontrados no lago Amanã estão associados a contextos funerários e rituais. Ainda é importante salientar que as formas das bordas não apresentam uma grande variação, geralmente são retas ou contraídas, e em menor grau expandidas, sendo raro o reforço da borda com aplicação de outro rolete. Os lábios serrilhados são marcantes e diagnósticos, ocorrem indistintamente em morfologias irrestritivas e restritivas.

Diferente de sua contemporânea Manacapuru onde flanges mesiais estão ausentes (Lima e Neves, 2011: 216), a fase Caiambé apresenta alguns exemplares como este elemento morfológico, mas são pouco expandidos e com uma decoração minimalista e sóbria, havendo ainda, aqueles de pequenas dimensões, sugerindo pertencer a vasos de pequenas proporções.

Apêndices e apliques modelados são frequentes, mas em menor escala quando comparamos com fases da tradição Pocó-Acutuba, e tendem para características híbridas e abstratas, com menor ênfase para representação zoomorfa. Entre os conjuntos artefatuais estão miniaturas, que são, relativamente, frequentes e também materiais de acompanhamento de sepultamentos no interior de urnas. Embora não seja possível afirmar o uso específico, as rodelas de fusos apresentam diferentes morfologias, discoidais com seções côncavas e planas, e também maciças decoradas por incisões, que sugere ser peso de rede ou adorno. Por fim, existe uma ampla produção de estatuetas que vão do antropomorfismo às representações bastante naturalistas de animais, além das estatuetas abstratas maciças (que apresentam similaridades com outras encontradas na Amazônia Central) e aquelas híbridas que mesclam elementos humanos e zoomorfos. 


\section{SigNIFICADOS DA FASE CAIAMBÉ NO LAGO AMANÃ NO PRIMEIRO MILÊNIO DA ERA CRISTÃ}

\section{Considerações}

Quando Hilbert definiu a fase Caiambé, Manacapuru e Paredão, as inserindo na Tradição Bora Incisa, na sua intepretação sobre a história cultural da Amazônia respaldou as proposições de Meggers e Evans, dando maiores informações contextuais sobre as ocupações na calha do Amazonas durante o primeiro milênio da Era Cristã. Com suas pesquisas, obteve-se a comprovação da ampla distribuição geográfica das ocupações relacionadas a esta tradição, que representava um momento de sedentarismo e agricultura na região. Mesmo concordando com isso, Hilbert dá destaque ao padrão de localização dos assentamentos observado por ele (altos de barrancos das várzeas, paranãs e canais que ligam lagos e grandes rios, zonas fronteiriças entre várzea e terra firme) que facilitavam o aproveitamento da flora e fauna dos principais ambientes ecológicos. Também as datas obtidas por Hilbert reforçavam a cronologia (hipotética) de Megger e Evans, mas suas análises da cultura material revelaram indisiocracias locais ${ }^{21}$ que apenas agora, com novas pesquisas, podem ser mais bem relacionadas.

De alguma maneira o cerne dos significados da Tradição Borda Incisa continua. Como demonstrado no capítulo 2, ela é vista como índice de uma importante transformação no modo de vida das populações amazônicas, ligada à adoção de uma economia mais dependente de práticas agrícolas (Neves, 2008; Neves et al, 2005), aos processos de formação de solos mais férteis, intensificação das técnicas de manejo e construção da paisagem e, em alguns casos, a padrões de assentamentos circulares (ArroyoKalin, 2010; Castro, 2009; Chirinos, 2006; Heckenberger, 2001; Moraes, 2006; 2010; Neves; 2008; Neves \& Petersen, 2005; Petersen et al, 2001).

\footnotetext{
${ }^{21}$ Naquele momento, a fase Paredão era a única que apresentou contextos funerários com sepultamentos em urnas bastantes características, já a fase Caiambé, era aquela mais antiga a apresentar o uso de técnicas policromas para a pintura - o que foi relacionado à sua localização mais a oeste e possíveis relações com os Andes.
} 
No Lago Amanã este quadro não é diferente, embora outras dinâmicas possam ser vislumbradas no que diz respeito ao período mais próximo do ano 1000. Com base nas informações apresentadas nos capítulos anteriores, parece razoável partir do pressuposto que tais ocupações parecem ser parte de um processo iniciado centenas de anos antes, durante a fase Pocó, mas se configuram como o ápice da ocupação integral de um território, com a formação de aldeias contemporâneas e espaços públicos e rituais. Esse pressuposto se baseia em pelo menos dois aspectos:

i) as datações radiocarbônicas disponíveis para diferentes sítios, cujo intervalo é pequeno o suficiente para comprovar o uso simultâneo desses espaços;

ii) práticas culturais específicas que podem ser relacionadas à matriz Arawak, muito além dos aspectos tecnológicos presentes na cerâmica, mas baseado em outras evidências contextuais presentes no registro arqueológico identificado.

No momento sabemos que as datas mais antigas disponíveis para a fase Caiambé estão situadas no século $\mathrm{V}$, trata-se do contexto funerário da urna 516 de Bom Jesus do Baré e da camada de terra preta de um setor do sítio Boa Esperança, ambos localizados na porção superior do lago Amanã. Mas é a partir do século VII que os sítios Caiambé são mais evidentes no Solimões, cujas ocupações não estão sobrepostas às anteriores. É possivel dizer que mais próximo à calha principal, os sítios tendem a ser maiores e densos (exemplos são os sítios escavados por Hilbert e o conjunto Vilas estudado por Belletti), enquanto que no lago Amanã eles tornam-se mais frequentes entre os séculos VIII e X, com camadas de terra preta espessas, embora pouco profundas, e nos dois casos aqui apresentados (Cacoal e São Miguel), com um conjunto artefatual bastante relacionado às principais características da tradição Borda Incisa. Contudo, nesses mesmos sítios, são encontrados materiais espassos, mas bastante diagnósticos da tradição Polícroma, e no sítio Boa Esperança particularmente, com uma data situada no século VIII.

Embora o argumento seja que outras evidências além da tecnologia cerâmica podem ser consideradas para caracterizar o registro arqueológico no lago Amanã como parte da longa história de ocupação Arawak, gostaria de lançar um olhar para as singularidades, hibridismo e fluxos entre as cerâmicas das fases locais e paralelos com a fase Manacapuru. 
As análises de Lima (2008) destacam a grande variabilidade das cerâmicas Manacapuru, mas alguma rigidez nos aspectos de manufatura das pastas, predominantemente temperadas com cauixi. Olhando para exemplares dessas cerâmicas provenientes do sítio Açutuba ao lado (Figura 72), é bastante ilustrativa as semelhanças estilísticas com a fase Caiambé (Conferir cap. 4). Embora os motivos curvilíneos tenham sido considerados por Lima mais diagnósticos, vemos também os motivos retilíneos bastante comuns nas cerâmicas do lago Amanã sendo reproduzidos nas cerâmicas na área de Confluência.

É interessante que também para a fase Manacapuru, a autora apresenta sítios com cerâmicas com flanges mesiais distintas das Polícromas, menos expandidas, provenientes do sítio Jacuruxi. Este sítio que apresenta um pacote discreto de terra preta, com duas datas disponíveis que indicam um intervalo de 80 anos de ocupação (490 d.C. 570 d.C.) possui cerâmicas que compartilham elementos das tradições PocóAçutuba e Borda Incisa. Sua interpretação caminha no sentido de que o material encontrado neste sítio seja um expoente de mudanças culturais, que estariam em curso durante os meados da Era Cristã.

Uma das principais questões dessa pesquisa era compreender em que medida a fase Caiambé representaria no lago Amanã um momento de mudanças culturais.
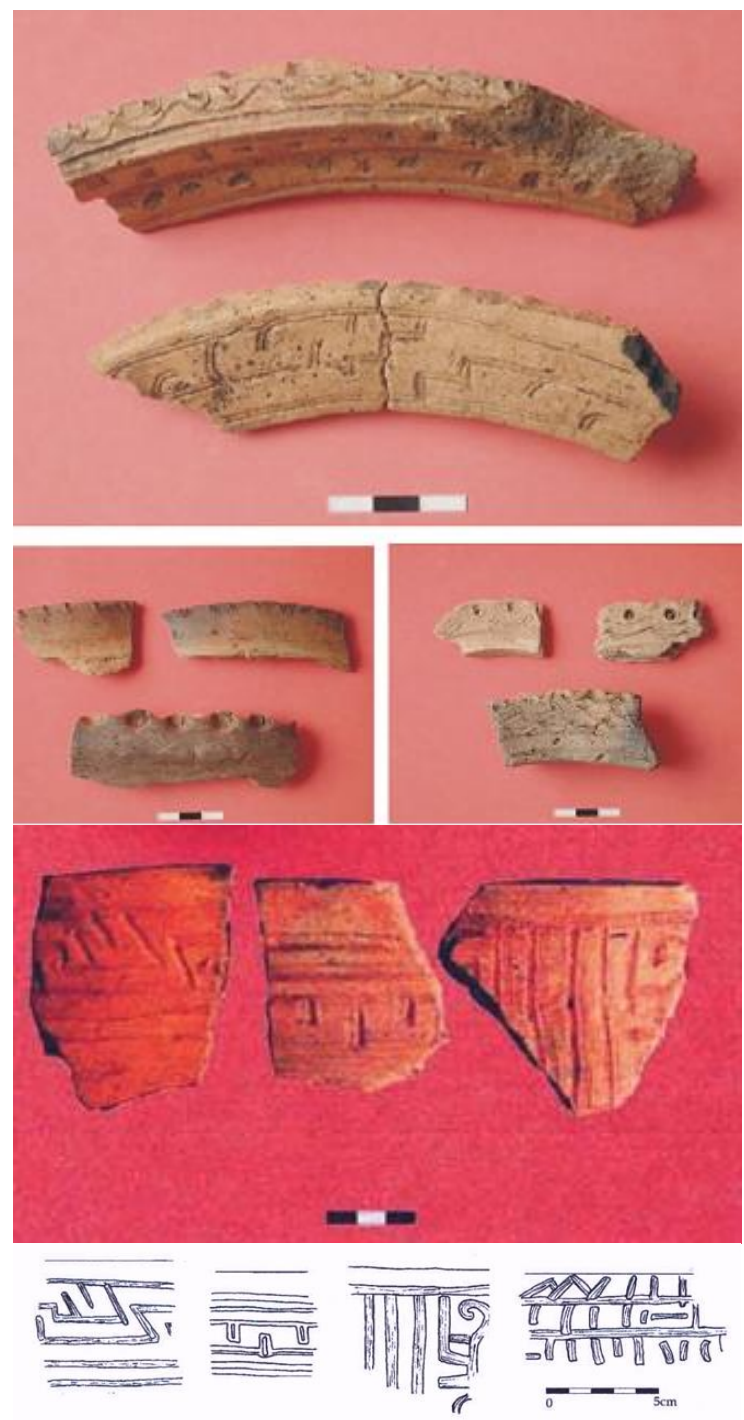

Figura 72: Fotos sítio Açutuba Fase mancapuru. Lima, 2008. Vagner Souza. Extraido de Lima 2008

Forma Reconstituida:
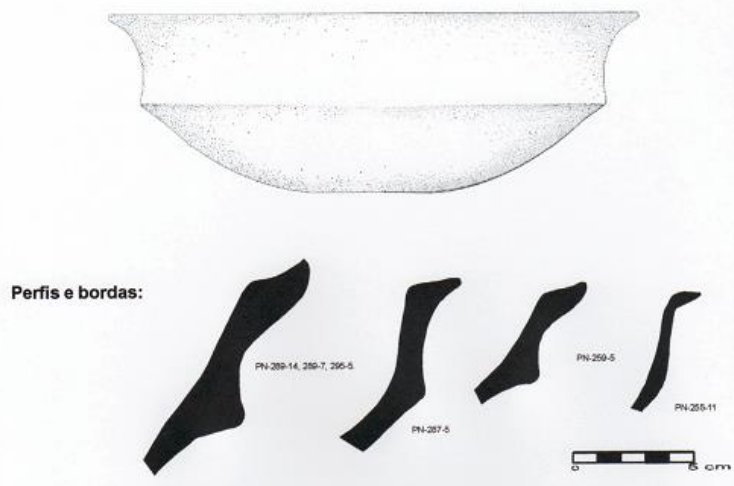

Figura 73: Perfis de bordas com carenas, formando discretas flanges mesiais, relacionadas a fase Manacapuru. 
Com base nas intervenções nos sítios Cacoal e São Miguel e da análise de suas cerâmicas, alguns elementos podem ser elencados como índices de continuidade cultural com a tradição Pocó-Açutuba, mas cujas particularidades locais nos remetem a processos e dinâmicas sócio-culturais distintas daquelas observadas na área de Confluência no que diz respeito à tradição Polícroma.

Comparadas à fase Mancapuru, as cerâmicas Caiambé apresentam maior variação na composição das pastas, embora o cauixi seja preponderante, o caraipé está sempre presente, como nas cerâmicas mais antigas identificadas na região. Em certa medida as cerâmicas da fase Tefé compartilham muito mais elementos decorativos comuns com a fase Caiambé, que a fase Guarita com a Manacapuru na área de Confluência do Negro e Solimões. Em termos morfológicos, dois aspectos são importantes: a tendência a irrestrição dos vasos com bordas formando flanges e suportes para a decoração, algo extremamente comum na fase Pocó; e também a presença initerrupta de flanges mesiais entre os complexos cerâmicos locais em toda a cronologia (ainda que preliminar) das ocupações de Amanã, embora as maneiras como tais flanges são manufaturados e decorados tenham se modificado ao longo do tempo.

Mas se a presente análise preocupou-se em caracterizar as cerâmicas Caiambé dando pouca atenção à fase Tefé, encontrada pontualmente nos sítios estudados, vale destacar as relações entre essas fases. Vasos com flange mesial funcionam como um fóssilguia da tradição Polícroma da Amazônia na calha do Amazonas (Heckenberger et al, 2001; Oliveira, 2014). No lago Amanã entre os contextos escavados, apenas o sítio Boa Esperança apresentou quatro componentes culturais distintos e ofereceu uma cronologia preliminar de ocupação (Costa, 2012). O período mais tardio, relacionado à fase Tefé parece ser o mais frágil dessa classificação, em virtude dos escassos materiais encontrados, bem como de datações de cerâmicas que apresentam uma inversão cronológica, contrariando, em parte, os modelos mais atuais (Cf Capítulo 2).

Lidamos com uma imensa dificuldade em determinar os contextos da tradição Polícroma no lago Amanã, onde os materiais são esparsos e aqueles que são seguramente vinculados a ela, apresentam características muito marcantes, como vasos com flange mesial típica, vasos de bordas reforçadas e fragmentos de paredes excisas. Mais comum é reconhecer elementos dessa tradição aplicados em vasos que seriam estruturalmente Borda Incisa. A urna coletada no sítio Cacoal representa uma síntese interessante dos principais elementos das fases locais, onde se mesclam técnica de policromia - em diferentes tons de vermelho e laranja, como nas cerâmicas mais antigas da tradição Pocó-Açutuba - e excisão 
de motivos interpretados como cobras bicéfalas extremamente comuns nas cerâmicas Polícromas (Moraes, 2013; Oliveira, 2014).

A fase Caiambé apresenta ampla ocorrência de urnas depositadas em grandes concentrações em contextos que sugerem ser exclusivamente funerários. Característica de fundamental importância nas fases Paredão e Manacapuru, os contextos funerários foram assinalados por Hilbert (1968) e melhor caracterizados recentemente (Moraes, 2006; Rapp Py-Daniel, 2008; 2014), mas até o momento, estavam ausentes na literatura sobre a tradição Borda Incisa na nossa área de pesquisa. Diante desse contexto funerário não há nenhum indício de urnas antropomórficas típicas da tradição Polícroma no lago ${ }^{22}$.

Não seria absurdo sugerir que o lago Amanã tenha sido um lugar significativo da paisagem do baixo Japurá durante o período da fase Caiambé, e depois, durante a expansão da Polícroma na calha do Amazonas, sendo um lugar de constituição física e espacial de memórias de uma ocupação milenar iniciada ainda durante período da tradição PocóAçutuba (Neves et al, 2014).

Esta talvez seja a contribuição mais importante desse trabalho, já que vemos no contexto local evidências daquele tripé básico de um ethos Arawak. No sítio São Miguel as manchas de terra preta estão dispostas de modo que podem ser correlatas da posição das áreas de habitação, ainda o sítio Cacoal apresenta um formato elíptico de distribuição do pacote arqueológico, mesmo que não tenha sido possivel distinguir claramente manchas como no caso do Sítio São Miguel. Portanto, é plausível considerar a existência de aldeia circular no lago Amanã, uma organização espacial extremamente característica das ocupações arawak. Do mesmo modo, evidências de regionalidade são claras o suficiente através da própria contemporaneidade de assentamentos, e uso simultâneo de espaços rituais específicos (cemitérios). Evidências dessa regionalidade são reforçadas na permanência e continuidade de elementos tecnológicos e simbólicos das cerâmicas. Por fim, o sedentarismo - relativizado em termos de sistemas agroflorestais e tecnologia de manejo florestal - está expresso na formação das camadas de terra preta. Se não prezasse pela cautela, ainda poderia ser elencado o elemento hierárquico das relações arawak, visto que a presença de urnas com indivíduos de idades diferentes chama atenção, pois o tratamento funerário parecido para diferentes faixas etárias pode ser interpretado como de sociedades mais igualitárias ou famílias com estatutos diferenciados, onde o estatuto é herdado e não adquirido (Costa et al, 2012).

22 Meggers e Evans (1968:98) citam o Lago Amanã como local de ocorrência de urnas antropomorfas da tradição Polícroma, com base nos materiais e informações analisados por Metruax (1930) e Feriz (1963). Contudo a urna antropomorfa em questão foi coletada no sítio Mapari, localizado na margem direita do médio curso do rio Japurá, a uma distancia de aproximadamente $280 \mathrm{Km}$ do lago Amanã. 
Considerando as informações cronológicas obtidas por nossa pesquisa, com mais datas próximo ao ano 1000 d.C para ocupações Caiambé - aliada à falta de evidência de conflitos, que poderia ser atestada pela presença de estruturas defensivas - parece ser plausível considerar que nesta região, ao contrário do baixo rio Madeira e da confluência dos rios Negro e Solimões - as tradições Borda Incisa e Polícroma envolveram relações amistosas, como casamentos, comércio, imitação e emulação entre os produtores de suas cerâmicas. No lago Amanã parece haver o estabelecimento de algum tipo de relação horizontal que permitisse a incorporação de diferentes grupos como se vê atualmente em áreas que têm influência de grupos Arawak em sua ocupação (Neves et al, 2014).

\section{Perspectivas}

No panorama geral desenhado por Costa (2012), já havia sido destacada a necessidade de compreender as relações entre as diferentes fases identificadas no sítio Boa Esperança, com indicação de locais para escavação, dentre eles Kalafate, Monte Sinai e São José do Urini. Começamos a tarefa nesta dissertação, mas devido ao próprio registro e possível unicomponencialidade dos sítios, a fase Caiambé foi aquela que mais ofereceu informações. Assim, uma das questões de pesquisa que era compreender suas relações com a fase Pocó, não foi, de fato, averiguada. Nesse sentido, no sítio Samaúma do Capuru, vizinho dos sítios São Miguel, Kalafate e Monte Sinai e que possui em superfície material típico Pocó-Açutuba, a coleta de amostras cerâmicas e seu estudo podem contribuir para esclarecer mudanças tecnológicas entre as fases e melhor caracterizar esse complexo cerâmico até o momento encontrado apenas no sítio Boa Esperança.

Quando comparamos as informações da fase Caiambé com outras fases Borda Incisa no quadro macrorregional, o lago Amanã possui certas idiossincrasias que merecem análises específicas. Este é o caso dos sítios-cemitérios. Poucas intervenções até o momento foram feitas e devem ser estendidas para outros setores do sítio Bom Jesus e empreendidas no sítio Kalafate e Monte Sinai. É fundamental entender as sobreposições das urnas - que ocorre também no sítio Boa Esperança (apesar de não ter sido tratado nesta dissertação) - se indicaria o retorno periódico ao lugar, nos oferencdo uma cronologia desses eventos, ou se é possível identificar alguma lógica de enterramento relacionado a pertencimentos e identidades sociais, ou a rituais específicos de enterramentos conjuntos. Compreender quando se inicia a prática de enterramentos em urnas é importante e deve ser verificado. $\mathrm{Na}$ área de confluência essa prática se inicia ainda durante as ocupações Pocó- 
Açutuba e se intensifica de uma maneira surpreendente durante a fase Paredão. Outra questão de pesquisa envolve também a ampliação das áreas de escavação nos sítios já conhecidos, de modo a confirmar as informações sobre formas de aldeia que começaram a ganhar mais respaldo com as análises espaciais.

Por outro lado investir na delimitação mesmo que grosseira da ocorrência da fase Caiambé com a continuação do levantamento de sítios é fundamental para conhecer parte das dinâmicas de ocupação dessas populações, já que o rio Japurá parece não ter sido um curso hidríco fundamental para o estabelecimento de aldeias durante essa fase. Ainda, considerando as informações apresentadas por Lima (2014) para o rio Unini, onde se destaca que as cerâmicas são mais relacionadas a fase Caiambé que com a fase Mancapuru, uma questão interessante é entender melhor a interação e fluxo entre essas áreas interioranas, afastadas do grandes cursos hídrico, que pode ser maior do que se pensava. Se nossa apreciação sobre a fase Japurá estiver certa, isto é, correlacionada à Tradição PocóAçutuba, o rio Japurá teria uma importância fundamental nos modelos para explicar a ampla distribuição dessas cerâmicas ainda antes da Era Cristã, podendo seus sítios também contribuir para o entendimento das mudanças e fluxos entre as tradições Pocó-Acutuba e Borda Incisa.

Quaisquer destas tarefas nos deixa diante de um problema latente enfrentado pelos arqueólogos na Amazônia, que é a primazia às pesquisas de caráter exploratório e comparativo, quase imposta devidos aos fatores pragmáticos de financiamento e logística das pesquisas. O retorno aos sítios já conhecidos a fim de responder perguntas específicas, muitas vezes não se justifica quando pensamos em quantos outros sítios estão sendo destruídos sem ao menos uma caracterização básica, ou enquanto existem áreas praticamente inexploradas. Mas acima de tudo uma questão teórica também subjaz nessas opções de pesquisas, visto que embora a arqueologia se pense como uma ciência histórica e antropológica, na Amazônia a prioridade analítica é dada à primeira.

Colocar em termos antropológicos ou sociológicos as similaridades e diferenças entre fases da Tradição Borda Incisa requer investimento de tempo e esforços multidisciplinares que avancem na direção de exaustivos estudos regionais. Ainda que a consideremos como um índice de um processo de ocupação intenso e duradouro das populações Arawak, essa tradição apresenta uma unidade que é topológica, isto é, embora a tamanha variabilidade da sua ocorrência expressa nas diversas fases, todas parecem variantes de uma estrutura básica de técnicas, cujas singularidades são um resultado histórico das interações e dinâmicas sociais locais. Destacar estes aspectos é o que parece mais motivador para entender a diversidade cultural no passado amazônico. 
Seja na RDS Amanã ou não, obviamente para seguir com essas questões é importante uma negociação de objetivos de pesquisas e envolvimento efetivo das comunidades locais. Machado (2009) em uma breve síntese sobre a forma de construção do passado amazônico pela arqueologia destacou que vivemos uma fase de amadurecimento crítico, com a busca por uma abordagem mais holística em vistas de superar as dicotomias ${ }^{23}$. Seis anos depois, se fosse possível acrescentar mais um momento nessa síntese, diria que estamos na fase do engajamento crítico. Não é mais possível fazer nossas pesquisas e negligenciar a importância do papel das comunidades locais e suas relações com o patrimônio arqueológico amazônico, tampouco não pensar em formas de oferecer benefícios reais para tais comunidades. Nesse sentido, o lago Amanã também oferece contextos sociais e políticos - organização comunitária, agentes institucionalizados - que podem garantir o sucesso das pesquisas arqueológicas de base comunitária que visem à valorização não apenas do patrimônio arqueológico, mas também da sociodiversidade local.

Tenho da minha primeira viagem ao lago Amanã, em fevereiro do ano de 2010, três lembranças muito específicas. A primeira trata-se da sensação de estar perdida, após os inúmeros caminhos hídricos percorridos, cujas classificações em paranãs e furos, todos nomeados, me deixaram zonza. A segunda lembrança é a imagem do próprio lago e suas duas faces: a primeira como um infinito calmo e sereno de águas pretas, margeado por uma vegetação monótona, cortada apenas pelas casas de madeira. A outra face conheci na viagem de retorno, quando uma chuva torrencial fazia o banzeiro ser forte o suficiente para obrigar nosso barqueiro navegar pelas margens do lago, mesmo com um motor e barco muito potentes. Naquele dia aprendi que Amanã significava caminho da chuva na língua dos índios. Por fim, lembro-me das pessoas. Os moradores das comunidades, dos sítios arqueológicos que seriam meus objetos de pesquisa. Pessoas já muito hábeis com os pesquisadores, que naquele momento, me pareciam bastante desinteressadas naqueles vestígios de ocupações passadas e também sobre o passado daquele lugar.

Dessas impressões, quase todas se desfizeram com o tempo. A rota e os nomes dos paranãs e furos foram posteriormente memorizados, sendo compreendidos por mim outros sentidos da relação entre cidade e interior, bem como das noções de

23 Para a autora, os três momentos da construção do passado amazônico pela arqueologia são: seu início, representado pelos trabalhos de Curt Nimuendaju (2004); a fase de consolidação teórica e metodológica, expressa nos trabalhos de Betty Meggers e Clifford Evans (Meggers, 1996, 1995; Meggers e Evans, 1957); e a fase de amadurecimento crítico, não mais centrada em um ou dois pesquisadores (Guapindaia, 2001; Gomes, 2001; Heckenberger, 2001; Neves, 1999; Oliver, 2001; Pereira, 2001; Petersen et al., 2001; Politis, 1995; Roosevelt, 1991; Schaan, 2004). 
distância e tempo para percorrer aqueles caminhos em diferentes momentos do ano durante a seca e a cheia. A paisagem monótona foi lentamente se revelando bastante diversificada e repleta de marcos, e as pessoas me permitiram compreender em alguma medida os sentidos da história local - muito mais relacionados às suas trajetórias e memórias, enunciadas por relações de parentesco, lugares e formas de relação com aquela paisagem. Portanto, muito distantes das minhas próprias ferramentas analíticas e objeto de estudo. Em alguma medida me esforcei para neste trabalho apresentar parte dessa experiência entre um mundo vivido bastante particular em torno do lago Amanã e minhas impressões a partir de uma maneira também particular de construir narrativas sobre o passado. 
Acunã, Cristobal

1641[1945] Novo descobrimento do grande rio das Amazonas. In: Descobrimentos do Rio das Amazonas. Tradutor Cândido de Melo Leitão. Disponível em:

http://www.brasiliana.com.br/obras/descobrimentos-do-rio-das-amazonas

Alencar, Edna

2007 Estudo da ocupação humana e mobilidade geográfica de comunidades rurais da Reserva de Desenvolvimento Sustentável Amanã - RDSA. Relatório Final. Santarém / Tefé. 168p.

2009 O tempo dos patrões 'brabos': fragmentos da história da ocupação humana na Reserva de Desenvolvimento sustentável Amanã, Am. Amazônica 1(1): 178-199.

2010 Dinâmica territorial e mobilidade geográfica no processo de ocupação humana. Uakari 6 (1): 39-58.

Almeida, Fernando

2013 A Tradição Polícroma no Alto Rio Madeira. Tese de doutorado apresentada no Museu de Arqueologia e Etnologi/ USP, São Paulo

Andrade, Angela

1986 Investigacion arqueologica de los antrosoles de Araracuara : Fundación de Investigaciones Arqueológicas Nacionales, Banco de la República, Bogota.

Andrade, Angela e P. Botero,

1984 Los antrosoles (Tropic Plaggepts) de Araracuara. Amazonia Colombiana. Revista CIAF, 9(1):25-39. Insituto Geográfico Agustin Codazzi (IGAC), Bogotá.

Atalay, Sonya

2008 Multivocality and Indigenous archaeologies. In Evaluating Archaeologies. Multiple Narratives, Beyond Nationalist, colonialist Imperialist, pp 29-44. Editado por Habu, J; Fawcett,C e Matsuunaga, J. Springer.

2010 'We don't talk about Çatalhöyük, we live it': sustainable archaeological practice through community-based participatory research. World Archaeology Vol. 42(3): 418-429

2012 Community-Based Archaeology: Research with, by, and for Indigenous and Local Communities. Berkeley: University of California Press, 328 p.

Balée, Willian

1989 The culture of Amazonian forests. in: Management in Amazonia: indigenous and folk strategies, p. 1-21. Editado por D. Posey e W. Balée. W Bronx: The New Botanical Garden.

Barcelos Neto, Aristóteles.

2001 Apontamentos para uma iconografia Xinguana. In: FRANCHETTO, Bruna \& HECKENBERGER, Michael (Orgs).Os Povos do Alto Xingu, História e Cultura.Editora UFRJ, Rio de Janeiro. 2001 pp. 193-218

2008 Apapaatai: rituais de máscaras no Alto Xingu. Edusp/Fapesp, São Paulo.

Barreto, Cristiana.

2012 Diagnóstio de musealização de sítios na RDS Amanã. Instituto de Desenvolvimento Sustentável Mamirauá. Manuscrito.

Bates, Henri 
2009 [1863] The Naturalist on the River Amazon. Cambridge: Cambridge University Press.

Belletti, Jaqueline.

2013 Mapeamento Arqueológico do Lago de Tefé, Médio Rio Solimões (Amazonas-Brasil). Relatório de qualificação submetido ao PPArq. Museu de Arqueologia e Etnologia da Universidade de São Paulo.

Bowser, Brenda e John Patton

2008 Learning and Transmission of Pottery Style. Women's life histories and communities of practice in the Ecuadorian Amazon. In Cultural Transmission and material culture.

Breaking down boundaries Editado por Stark et al. The university of Arizona press, p. 105 $-129$.

Brightman, M.

2010 Creativity and Control: Property in Guianese Amazonia. Journal de la Société des Américanistes 96(1): 135-167

Brochado, José Proenza

1984 An ecological model of the spread of pottery and agriculture into eastern south america. 1984. 578f. Tese (doutorado em Filosofia e Antropologia) - University of Illinois at Urbana-Champaign, Carbondale,

1989 A Expansão dos Tupi e da Cerâmica da Tradição Polícroma Amazônica. Dédalo, São Paulo, 1989, p. 65-82.

Brochado, José e Donalt Lathrap

1982 Chronologies in the New World: Amazônia. Department of Anthropology, University of Illinois at Urbana-Champaign. Illinois, 1982. Manuscrito

Cabral, Ana Suelly

2011 Different Histories, Different Results: the origin and development of two Amazonian Languages. Papia 21: 9-33

Cabral, Ana Suelly e Arion Rodrigues,

2003 Evidências de crioulização abrupta em Kokama? Papia, n13, pp 180-186

Carneiro, Gabriela

2012 Un cas de subsistance par la pêche en Amazonie: le site archéologique Hatahara

(Amazonas, Brésil). Dissertação de Mestrado. Muséum National d'Histoire Naturelle, MNHN, França

Caromano, Caroline Fernandes

2010 Fogo no Mundo das Águas: antracologia no sítio Hatahara, Dissertação de Mestrado, Programa de Pós-Graduação em Arqueologia, Museu Nacional, Universidade Federal do Rio de Janeiro.

Carvajal, Gaspar

1542 [1945] Relação que escreveu Fr. Gaspar de Cavajal. In: Descobrimentos do Rio das Amazonas. Tradutor Cândido de Melo Leitão. Disponível em:

http://www.brasiliana.com.br/obras/descobrimentos-do-rio-das-amazonas

Cascon, Leandro

2010 Alimentação na Floresta Tropical: um estudo de caso no sítio Hatahara, Dissertação de Mestrado, Programa de Pós-Graduação em Arqueologia, Museu Nacional, Universidade Federal do Rio de Janeiro.

Castro, Marcio. 
2009 A cronologia dos sítios Lago do Iranduba e Laguinho à luz das hipóteses de ocupação humana para a Amazônia central. Dissertação (Mestrado em Arqueologia). Museu de Arqueologia e Etnologia da Universidade de São Paulo, São Paulo.

Cavelier, I., C. Rodriguez, L. Herrera, G. Morcote e S. Mora,

1995 No solo de caza vive el hombre: ocupación del bosque Amazónico, Holoceno temprano. Ambito y Ocupaciones Tempranas de la America Tropical. Editado por I. Cavelier e S. Mora, pp. 27-44. Fundación ERIGAIE - Instituto Colombiano de Antropologia, Bogotá.

Costa, Bernardo

2008 Levantamento Arqueológico na RDS Amanã. UAKARI, v.4, n²2, pp 7-19.

2009 Plano de Manejo do Patrimônio Arqueológico Existente na RDS Amanã. Instituto de Desenvolvimento Sustentável Mamirauá. Relatório Final apresentado ao CNPq/PCI. Inédito

2012 Levantamento Arqueológico na RDS Amanã - Estado do Amazonas. Dissertação de Mestrado Museu de Arqueologia e Etnologia da Universidade de São Paulo, São Paulo.

Costa, Bernardo, Anne Rapp Py-Daniel, Jaqueline Gomes e Eduardo Neves

2012 Urnas funerárias no Lago Amanã: Contextos, gestos e processos de conservação.

Amazônica 4 (1): 60-91.

Childe, Gordon

1957 The Dawn of European Civilization. London: Routledge Kegan Paul.

Chirinos, Ricardo

2007 A variabilidade espacial no sítio Osvaldo. Estudo de um assentamento da tradição barrancóide na Amazônia Central. 213f. Dissertação (Mestrado em Arqueologia) - Museu de Arqueologia e Etnologia da Universidade de São Paulo, São Paulo.

Chmyz, Igor.

1966 Terminologia Arqueológica Brasileira para a Cerâmica. Manuais de Arqueologia, n. 1. Centro de Ensino e Pesquisas Arqueológicas, Universidade Federal do Paraná, Curitiba.

Colwell-Chanthaphonh, C. e T. J. Ferguson

2008 Collaboration in archaeological practice: engaging descendent communities. Lanham: Altamira Press.

Conklin, B.A

2001 Consuming grief: Compassionate cannibalism in an Amazonian society. Austin: University of Texas Press.

DeBoer, W e Donald Lathrap

1979 The making and braking of Shipibo-Conibo Ceramics. In: Etnoarchaeology: Implications of etnography for Archaeology. Editado por C. Kramer. Pp.102-138.

Dickau, Ruth, Maria Bruno, Jose Iriarte, Heiko Prümers, Carla Jaimes Betancourt, Irene Holst, Francis Mayle.

2011 Diversity of cultivars and other plant resources used at habitation sites in the Llanos de Mojos, Beni, Bolivia: evidence from macrobotanical remains, starch grains, and phytoliths. Journal of Archaeological Science xxx (2011) 1-14.

Dietler, M.; Herbich, I.

1998 Habitus, techniques, style: an integrated approach to the social understanding of material culture and boundaries. In: STARK, M. (Ed.). The archaeology of social boundaries. Washington: Smithsonian Institution Press, 1998. p. 223-244.

Donatti, Patrícia. 
2003 A ocupação pré-colonial da área do lago Grande, Iranduba, AM. 140f. Dissertação (Mestrado em Arqueologia) - Museu de Arqueologia e Etnologia da Universidade de São Paulo, São Paulo, 2003.

Eder, James

1982 Terra preta soils and their archaeological contexto in the Caqueta Basin of southeast Colombia. American Antiquity, vol.47, n 1:125-140.

Eden, Michael J., Warwick Bray, Leonor Herrera and Colin McEwan,

1984 Terra Preta soils and their archaeological context in the Caquetá basin of southeast Colombia. American Antiquity v 49 n¹, pp. 125-140.

Eidt, Robert

1977 Detection and examination of antrosols by phosphate analysis. Science 197:1327-1333.

Falhauber, Priscila

1992 O navio encantado: etnia e alianças em Tefé. Coleção Eduardo Galvão. Belém: Museu Goeldi/CNPq-MCT.

2008 Introdução. In Tastevin e a Etnografia Indígena Organizados por Faulhaber, P. e Monserrat, R. Museu do Índio.Rio de Janeiro.

2011 'Ambientalização dos conflitos', indigenismo e lutas sociais no Médio Solimões: As terras indígenas e o projeto Mamirauá. Revista ANTHROPOLÓGICAS, ano 15, vol.22(1): 97117 (2011)

Feriz, Henri

1963 The ceramics of Tefé-Amaná: A Contribution to the Archeology of the Amazon. Revista Ethnos, v. 28, pp.147-176.

Furquim, Laura

2014 Análise Laboratorial do Material Cerâmico do Sítio São Miguel do Cacau e Monitoramento dos Sítios em Área de Comunidade no Lago Amanã - RDSA - AM. Relatório Científico apresentado ao CNPq. Tefé. Inédito

Galvão, Eduardo

1954 Santos e Visagens: um estudo da vida religiosa de Itá, Amazonas. São Paulo: Companhia Editora Nacional.

Gell, Alfred.

1998 Art and agency: an anthropological theory. Oxford University, Oxford Press.

Gomes, Jaqueline

2011 ${ }^{\mathrm{a}}$ Análise Laboratorial do Material Cerâmico dos Sítios Boa Esperança e Cacoal. Relatório Técnico Final apresentado ao CNPq. Tefé. Inédito.

$2011 \mathrm{~b}$ Is it true that this place used to be an Indian village? Ceramic analysis and preliminary chronology of Boa Esperança archeological site, located in Amanã SDR, Mid Solimões River, State of Amazonas, Brazil”. Uakari 7(2):7-20.

2012 Arqueologia e Cultura Material na RDS Amanã: Análise Cerâmica dos Sítios Cacoal, Calafate e São Miguel. Relatório Técnico Final apresentado ao CNPq. Tefé. Inédito

Gomes, Jaqueline e Bernardo Costa

2010 Resultados Preliminares da Análise Tecnológica e Estilística da Indústria Cerâmica do Sitio Boa Esperança - Reserva de Desenvolvimento Sustentável Amanã (RDSA), AM.In: Encontro Internacional de Arqueologia da Amazônia, 2, Cd de Resumos, Manaus. Manaus: UEA; SAB Norte; CNPq.

Guapindaia, Vera

2008 Além da margem do rio - a ocupação Konduri e Pocé na região de Porto Trombetas, PA. Tese (Doutorado em Arqueologia) - Museu de Arqueologia e Etnologia da Universidade de São Paulo, São Paulo, 2008. 
Guapindaia, Vera e João Ayres Fonseca

2013 Metodologia de delimitação no sítio arqueológico Cipoal do Araticum na região do rio Trombetas, Pará, Brasil. Bol. Mus. Para. Emílio Goeldi. Cienc. Hum., Belém, v. 8, n. 3, p. 657-673.

Guapindaia, Vera e Daniel Lopes

2012 Estudos Arqueológicos na Região de Porto Trombetas, PA. Revista de Arqueologia da Sociedade de Arqueologia Brasileira. V.24. Pp.50-73.

Hays, Kelley

1992 Anasazi ceramics as text and tool: toward a theory of ceramic design "messaging". Tese de Doutorado. University of Arizona.

Hanke, Wanda

1959 Archäologische Funde im oberen Amazonasgebiet. Archiv für Völkerkunde, Wien.

Harris, M.

2005. Riding a Wave: Embodied Skills and Colonial History on the Amazon Floodplain. Ethnos, 70 (2):197-219.

Hatcher, Evelyn

1974 Visual metaphors: a methodological study in visual communicaion. Alburqueque, University of New Mexico Press.

Heckenberger, Michael

2001 Estrutura, história e transformação: a cultura xinguana da long durée, 1000-2000d.C. In: HECKENGERBER, Michael; FRANCHETO, Bruna. (Orgs.). Os povos do alto Xingu. Rio de Janeiro: UFRJ, 2001, p. 21-62.

2005 The Ecology of Power: Culture, Place and Personhood in the Southern Amazon, AD 1000-2000. New York: Routledge.

Heckenberger, Michael; Eduardo Neves e James Petersen

1998 De onde surgem os modelos? Considerações sobre a origem e expansão dos Tupi. Revista de Antropologia, v. 41, n. 4, p. 69-96.

1999 Village permanence in Amazonia: two archaeological examples from Brazil. Latin American Antiquity, v. 10, n. 4, pp. 353-376.

Heckenberger, Michael e Eduardo Neves

2009 Amazonian Archaeology. Annual Review of Anthropology, v. 38, p. 251-266.

Hegmon, M e S. Kulow

2005 Painting as Agency, Style as Strutucture: Innovations in Mimbres Pottery Designs From Southwest New México. Journal of Archaeological Method and Theory, Vol. 12, No. 4, pp. 313 -334.

Herbert, 1907

Herrera, Luisa Fernanda, Santiago Mora e Inés Cavelier

1988 Araracuara: selección y tecnologia em el primer milênio A.D.. Colombia Amazónica 3(1): 75-87.

Herrera, Luisa Fernanda, Inés Cavelier, Camilo Rodríguez e Santiago Mora

1992 The technical transformation of an agricultural system in the Colombian Amazon. Word Archaeology, v.24, n.1, p. 98-113.

Herrera, Leonor, Warwick Bray e Colin McEwan,

1980-81 Datos sobre la arqueología de Araracuara (Comisaría del Amazonas Colombia).

Revista Colombiana de Antropología XXIII, pp 184-251

Hilbert, Peter

1968 Archäologische Untersuchungen Am Mittlern Amazonas, Berlim: Dietrich Reimer Verlag. 
1962a New stratigraphic evidence of culture change on the middle Amazon (Solimões). Akten des $34^{\circ}$ Internationalen Amerikanistenkongresses, p. 471-476.

1962b Preliminary Results of Archeological Research on the Japura River, Middle Amazon. Akten des $34^{\circ}$ Internationalen Amerikanistenkongresses, p. 465-470.

Hilbert, Peter e Klaus Hilbert,

1980 Resultados preliminares da pesquisa arqueológica nos rios Nhamundá e Trombetas, Baixo Amazonas. Boletim do Museu Paraense Emílio Goeldi, Nova Série, Antropologia, n 75, pp. $25-42$

Hill, Jhonathan

2002 Shamanism, Colonialism, and the Wild Woman: Fertility Cultism and Historical Dynamics in the Upper Rio Negro Region. In Comparative Arawakan historics: rethinking language family and culture area m Amazonia. Organizado por Fernando Santos-Granero e Jhonathan Hill. Urbana: University of Illinois Press, 2002

Hill, Jhonathan e Fernando Santos-Granero,

2002 Introduction. In: Comparative Arawakan historics: rethinking language family and culture area m Amazonia. Organizado por Fernando Santos-Granero e Jhonathan Hill., Urbana: University of Illinois Press, 2002, p. 1-22

Hodder, Ian

2000 Towards reflexive method in archaeology: the example at Çatalhöyük. Cambridge, McDonald Institute for Archaeological Research.

Hornborg e Ericksen, 2011

James Betancourt, Carla

2010 La cerâmica de la Loma Salvatierra. Inaugural - Dissertação de Mestrado. Zur Erlangung der Doktorwürde der Philosophischen Fakultät der Rheinischen Friedrich Wilhelms - Universität zu Bonn.

IDSM.

2010 Relatório Anual do Contrato de Gestão Celebrado entre o MCT e o IDSM-OS. Apêndices e Anexos. Exercício de 2009. Parte I. Tefé. AM

Koch-Grunberg, Teodor

2005 Dois anos entre os Indígenas (1903-1905). Editora da UFAM: Faculdade Dom Bosco, Manaus.

Kuwanwisiwma, L. J.

2008 Collaboration means equality, respect, and reciprocity: a conversation about archaeology and the Hopi tribe, in Collaboration in archaeological practice: engaging descendent communities. Editado por C. Colwell-Chanthaphonh e T.J. Ferguson, pp. 151-169.

Lanham: Altamira Press.

LaCondamine, C. M

1745 [1992] Viagem pelo Amazonas, 1735-1745. Editora Nova Fronteira Rio de Janeiro.

Lathrap, Donald

1970 The Upper Amazon. London, Thames and Hudson.

Lagrou, Els

2007 A Fluidez da Forma: arte, alteridade e agência em uma sociedade amazônica (Kaxinawá, Acre). TopBooks, UFRJ. Rio de Janeiro.

Lemonnier, $\mathrm{P}$.

1992 Elements for an anthropology of technology. Michigan: University of Michigan, Museum of Anthropological Research, 1992. (Anthropological Papers, 88).

Lima-Ayres, Déborah 
1992 The social category caboclo: History, social organization, identity and outsider's social classification of the rural population of an Amazonian region (the middle Solimões). Tese de Doutorado, Universidade de Cambridge, Inglaterra.

Lima, Deborah

2005 The Roça Legacy: land use and kinship dynamics in Nogueira, an Amazonian community of the middle Solimões region. In Some other Amazonians: perspectives on modern Amazonia, pp 12-36. Organizado por M. Harris e S. Nugent, Londres: University of London, Institute of Latin American Studies.

2010 As transformações na economia doméstica de Mamirauá. Uakari, 6(1): 9-26.

Lima, Déborah e Edna Alencar,

2000

Lima, Déborah, Eduardo Neves, Nelissa Peralta, Isabel Soares, Bernardo Costa, Priscila Nardey, Antônio Francisco, Raimundo Reis e Fernando Costa.

2006 Participação Comunitária e Manejo de Recursos Arqueológicos em uma Reserva de Desenvolvimento Sustentável na Amazônia. Projeto de Pesquisa. Inédito.

Lima, Helena

2008 História das Caretas: A Tradição Borda Incisa na Amazônia Central. Tese de Doutorado, Museu de Arqueologia e Etnologia, Universidade de São Paulo.

2010 A 'longue durée' e uma antiga história na Amazônia Central. In: PEREIRA, Edithe e GUAPINDAIA, Vera. (orgs.) Arqueologia Amazônica. v.2. Belém. MPEG; IPHAN; SECULT, 2010. p. 605-627.

Lima, Helena E. G. Neves e J. Petersen,

2006 A Fase Açutuba: Um Novo Complexo Cerâmico na Amazônia Central. Arqueologia Suramericana, Popayan - Colombia, v. 2, n. 1. pp. 26-52.

Lima, Marjorie

2014 O Rio Unini na Arqueologia da Bacia do Rio Negro. Dissertação (Mestrado em Arqueologia) - Museu de Arqueologia e Etnologia da Universidade de São Paulo, São Paulo

Lowie, R.

1948 The Tropical Forests: An Introduction, In: Handbook of South American Indians, vol. 3, J. Steward, ed. Washington, DC: Bureau of American Ethnology, Smithsonian Institution, Bulletin 143, 1948, pp. 1-56.

Machado, Juliana

2005 Montículos Artificiais na Amazônia Central: um Estudo de Caso do Sítio Hatahara.367 f.

Dissertação (Mestrado em Arqueologia) - Museu de Arqueologia e Etnologia da Universidade de São Paulo, São Paulo.

2006 O significado dos sistemas tecnológicos: classificando e interpretando o vestígio cerâmico. Arqueologia Sul Americana,Popayan, v.3, n. 1. p. 62-83, 2007

Marcoy, P.

[1862] 2001. Viagem pelo Rio Amazonas. Tradução de Antonio Porro. Editora da Universidade do Amazonas e Edições Governo do Estado.

Marshall, Y.

2002 What is community archaeology. World Archaeology 34(2):211-219

Meggers, Betty

1954 Environmental Limitation on the Development of Culture. American Anthropologist

1987 Amazônia: a ilusão de um paraíso. São Paulo: Editora da Universidade de São Paulo 
1990 Reconstrução do Comportamento Locacional Pré-Histórico na Amazônia. Boletim do Museu Paraense Emilio Goeldi, NS, Antropologia, vol.6 (2): 183-203.

1992 Prehistoric Population Density in the Amazon Basin. In: Disease and Demography in the Americas Editado por Verano, J. e Ubelaker, D. Smithsonian Institution Press, Washington, DC. pp. 197-205.

1997 La cerámica temprana en América del Sur: invención independiente o difúsion? Revista de Arqueologia Americana 13, p. 7-40.

Meggers, Betty e Cliford Evans,

1957 Archeological Investigations at the Mouth of the Amazon. Smithsonian Institution. Washington D.C..

1961 An experimental Formulation of Horizon Styles in the Tropical Forest Area of South America. In: LOTHROP, Samuel. (Ed.). Essays in Precolumbian Art and Archaeology. Cambridge: Harvard University

1970 Como Interpretar a Linguagem da Cerâmica: Manual para Arqueólogos. Smithsonian Institution, Washington,

1977 Las Tierras Bajas de Suramérica y Las Antillas. Revista de La Universidad Catolica, Ecuador, ano 5, n 17, p. 11 -70, 1977. (Numero Monografico de Arqueologia)

1983 Lowland South America and the Antilles. In: Ancient South Americans, Jesse Jennings, ed. San Francisco: W. H. Freeman, pp. 287-335.

Menegassi, Juliana

2009 Conhecimento sobre o uso de plantas utilizadas na produção de objetos artesanais Reserva de Desenvolvimento Sustentável Amanã. Em: Sustentabilidade ambiental da exploração de recursos naturais por artesãos das Reservas de Desenvolvimento Sustentável Mamirauá e Amanã, Amazonas. Relatório Técnico Final apresentado ao CNPq. Tefé. Inédito.

Meskell, L. (Ed.)

2009 Cosmopolitan Archaeologies. Duke University Press.

Métraux, Alfred.

1930 Contribution à l'étude de l'archéologie du cours supérieur et moyen de l'Amazone. Revista del Museo de la Plata. Buenos Aires, vol. 32, pp. 145-85

Myers, Thomas

2004 Dark Earth in the Upper Amazon. In: Glaser, B. \& Woods, W. I. (eds), Amazonian Dark Earths: Exploration in Space and Time. Springer Verlag, Berlin, pp. 67-94

Mora, Santiago, Luisa F. Herrera, Inés Cavelier e Camilo Rodríguez

1991 Plantas cultivadas, suelos antrópicos y astabilidad. Informe preliminar sobre la arqueologia de Araracuara, Amazonia colombiaa. University of Pittsburg, Latin American Archaeology Reports, n2.

Moraes, Claide P.

2006 Arqueologia na Amazônia Central vista de uma Perspectiva da Região do Lago do Limão. Dissertação de Mestrado. Museu de Arqueologia e Etnologia da Universidade de São Paulo.

2010 Aldeias circulares na Amazônia Central: um contraste entre fase Paredão e fase Guarita, in Arqueologia Amazônica. Editado por E. Pereira e V. Guapindaia, pp.582-604. Vol.2. Museu Paraense Emilio Goeldi. Belém.

2013 Amazônia Ano 1000: territorialidade e conflito no tempo das chefias regionais. Tese de Doutorado, MAE-USP, São Paulo.

Moraes, Claide e Eduardo Neves,

2012 O Ano 1000: Adensamento Populacional, Interação e Conflito na Amazônia Central. Amazônica: Revista de Antropologia, 4: 122-148.

Moser, S., D. Glazier, J. E. Phillips, L. N. el Nemr, M. S. Mousa, R. N. Aiesh, S. Richardson, A. Conner, e M. Seymour. 
2002 Transforming archaeology throught practice: strategies for collaborative archaeology and the community archaeology project ar Quseir, Egypt. World Archaeology 34(2):220-248

Netto, Ladislau

1885 Investigações sobre a Arqueologia Brasileira. Arquivos do Museu Nacional, vol. 6.

Neves, E.

1999-2000 O Velho e o Novo na Arqueologia Amazônica. Revista USP, Brasil, v. 44:87-113.

1999 Changing Perspectives in Amazonian Archaeology. In: POLITIS, Gustavo; ALBERTI, Benjamin (Eds.). South American Archaeology. Londres: Routledge, 1999. p. 216-243

2000 Levantamento Arqueológico na Área de Confluência dos Rios Negro e Solimões, Estado do Amazonas. Relatório de Atividades Apresentado à FAPESP. Museu de Arqueologia e Etnologia. Universidade de São Paulo

2006 Arqueologia Amazônica.Rio de Janeiro, Zahar Editor.

2007 El Formativo que nunca terminó: la larga história de la estabilidad en las ocupaciones humanas de la Amazonía Central. Boletín de Arqueología PUCP, v. 11, p. 117-142.

2008 Ecology, Ceramic Chronology and Distribution, Long-term History, and Political Change in the Amazonian Floodplain. In: Handbook of South American Archaeology, pp 359379. Editado por H. Silverman e W. Isbell, New York:Springer.

2010 A Arqueologia da Amazônia central e as classificações na Arqueologia Amazônica. in Arqueologia Amazônica. Editado por E. Pereira e V. Guapindaia, pp. 562-579. Vol.2. Museu Paraense Emilio Goeldi. Belém.

2011 El nacimiento del "Presente Etnográfico": la emergencia del patrón de distribución de sociedades indígenas y famílias linguísticas en las tierras bajas sudamericanas, durante el primer milenio d. C.. In: Jean-Pierre Chaumeil; Óscar Espinosa de Rivero; Manuel Cornejo Chaparro. (Org.). Por donde hay soplo: Estudios amazónicos ne los países andinos. Lima: Instituto Francés de Estudios Andinos, 2011 a, v. , p. 39-65.

2011 Archaeological Cultures and Past Identities in Precolonial Central Amazon. In: Alf Hornborg; Jonathan Hill. (Org.). Ethnicity in Ancient Amazonia: Reconstructing Past Identities from Archaeology, Linguistics, and Ethnohistory. Boulder: University of Colorado Press, 2011, v. , p. 31-56.

2013 Sob o tempo dos equinócios: oito mil anos de história. Tese de livre docência. Museu de Arqueologia e Etnologia da Universidade de São Paulo.

2014 Memorial para concurso de Professor titular em arqueologia brasileira. Museu de Arqueologia e Etnologia da Universidade de São Paulo. Inédito.

Neves, Eduardo; James Petersen. The Political

2005 Economy of Pre-Columbian Landscape Transformations in Central Amazonia. In: BALÉE, William; ERICKSON, Clark. (Eds.). Time and Complexity in Historical Ecology: Studies in the Neotropical Lowlands. New York: Columbia University,.p. 279-310.

Neves, Eduardo; James Petersen; Robert Bartone; Carlos Silva

2003 Historical and Socio-cultural origins of Amazonian dark earths. In: LEHMANN, Johannes, et al. (Eds.). Amazonian Dark Earths: Origin, Properties, Management. Dordrecht: Kluwer Academic, p. 29-45.

Neves, E. G., M. Arroyo-Kalin, R.Bartone, F. W. S. Costa, P. Bayod Donatti, B. Glaser, J. S. Machado, C. J. Munita, L. F. E. Lima, J. B. Petersen, H. P. Lima, L. Rebellato, C. A. da Silva, E. A. Soares

2003 Relatório de Atividades do Projeto Levantamento Arqueológico da área de Confluência dos Rios Negro e Solimões, Estado do Amazonas: Continuidade das Escavações, Análise da Composição Química e Montagem de um Sistema de Informações Geográficas. Relatório Científico apresentado à FAPESP. São Paulo

Neves, Eduardo e Estephen Rostain,

2012 Diversité linguistique et agrobiologique dans le passé amazonien. In: Nathan Schlanger; Anne-Christine Taylor. (Org.). La préhistoire des autres: perspectives archéologiques et anthropologiques. 1ed.Paris: La Découverte, p. 119-136 
Neves, Eduardo, Jaqueline Gomes e Bernardo Costa

2014 Plano de Manejo Comunitário do patrimônio Arqueológico existente na RDS Amanã, Estado do Amazonas. Relatório encaminhado ao IPHAN. Inédito.

Neves, Eduardo, Vera Guapindaia, Helena Lima, Bernardo Costa e Jaqueline Gomes

no prelo. $\quad$ A Tradição Pocó-Açutuba e os primeiros sinais visíveis de modificações de paisagens na calha do Amazonas

Nordenskiold, E.

1930 L’archéologie du bassin de l’Amazone. Ars Americana, vol. 1. Paris

Oliveira Filho, J.P.

1979 O caboclo e o brabo: notas sobre duas modalidades de força de trabalho na expansão da fronteira amazônica no século XIX. In: Encontros com a civilização Brasileira. v. 11, p 101-140.

Oyela-Caycedo, Augusto

1999 Arqueología: 30 años de história marginal. In: Ciencias sociales em la Amazônia Colombiana. pp 11-29.

Parente, M.T.

2009 Preservação arqueológica e sóciodiversidade na Amazônia. Memorial de qualificação. Museu de Arqueologia e Etnologia da Universidade de São Paulo. Inédito

Parente, M.T e Jaqueline Gomes,

2011 Relatório de Atividades de Educação Patrimonial. Relatório de Atividades apresentado ao IDSM. Inédito.

Pärssinen, M., D. Schaan e A. Ranzi.

2009 Pre-Columbian geometric earthworks in the upper Purús: A complex society in western Amazonia. Antiquity 83(322):1084-1095

Peralta, Nelissa.

2012 “Toda ação de conservação precisa ser aceita pela sociedade": Manejo Participativo em Reserva de Desenvolvimento Sustentável. Tese de Doutorado, Universidade Federal de Minas Gerais, Belo Horizonte.

Pereira, K. J. C.

2008 Agricultura Tradicional e manejo da agrobiodiversidade na Amazônia Central: um estudo de caso nos roçados de mandioca nas Reservas de Desenvolvimento Sustentável Amanã e Mamirauá, Amazonas. Tese de Doutorado - Programa de Pós Graduação em Ecologia Aplicada, da Universidade de São Paulo (Escola Superior de Agricultura Luiz de Queiroz, Centro de Energia Nuclear na Agricultura), São Paulo.

Petersen, J; Neves, E; Heckenberger, M.

2001 Gift from the past: Terra Preta and Prehistoric Amerindian Occupation. In Unknown Amazon: culture in nature in Ancient Brazil Amazonia. Editado por McEwan, C; Barreto, C; Neves, E. The British Museum Press. Londres:86-107

Porro, Antônio

1995 O Povo das águas: ensaios de etno-história amazônica. Petrópolis: Vozes.

Queiroz, Helder

2005 A Reserva de Desenvolvimento Sustentável Mamirauá. Estudos Avançados, 19 (54): 183203.

Queiroz, Helder Nelissa Peralta 
2005 Reserva de Desenvolvimento Sustentável: manejo integrado dos recursos naturais e gestão participativa. Em B. Becker e I. Garay (eds.). Dimensões humanas da biodiversidade. Rio de Janeiro, Vozes.

Queiroz, Helder, Alexandre Hercos e Henrique Zallarotto

2008 Plano de Manejo das áreas de coleta de peixes ornamentais da Reserva Amanã. Instituto de Desenvolvimento Sustentável Mamirauá IDSM-OS/MCT, Tefé.

Rapp Py-Daniel, Anne.

2009 Arqueologia da morte no sítio Hatahara durante a fase Paredão. 2009. 134f. Dissertação (Mestrado em Arqueologia) Museu de Arqueologia e Etnologia da Universidade de São Paulo, São Paulo, 2009.

2011 Relatório da Visita Técnica - Análise de Material ósseo. Tefé, Instituto de Desenvolvimento Sustentável Mamirauá - OS/MCT, 2011.

Rebellato, L.

2007 Interpretando a Variabilidade Cerâmica e as Assinaturas Físicas e Químicas no Solo no Sitio Arqueológico Hatahara-AM. Dissertação de Mestrado. Museu de Arqueologia e Etnologia. Universidade de São Paulo.

Reichel von Hildebrand, Elizabeth

1975 Levantamiento de los petroglifos del rio Caquetá entre La Pedrera e Araracuara. Revista Colombiana de Antropología. 19: 303-370.

1976 Resultados preliminares del reconocimiento del sítio arqueológico de Pedrera (Comisaría del Amazonas, Coombia). Revista Colombiana de Antropología. 20:145-176.

Rouse, Irving \& José Cruxent.

1963 Arqueología Venezolana. Instituto Venezolano de Investigaciones Científicas, Caracas, 212 $\mathrm{p}$

Rye, O.

1981 Pottery technology: principles and reconstruction. Manuals on archaeology, n. 4. Washington, D.C.: Taraxacum, $150 \mathrm{p}$.

Santos, Rafael B. C.

2012 Passar para Índio: etnografia das emergências indígenas no médio Solimões. Relatório Final de Pesquisa CNPq/PCI. Inédito.

Souza, Mariana e Rafael B. C. Santos,

2011 No médio Solimões: a emergência indígena em duas Unidades de Conservação (Amazonas, Brasil). Manuscrito.

Shepard, Glen

2001 Relatório Preliminar sobre Sítio Arqueológico e Cemitério Indígena na Reserva Amanã. 1 ${ }^{\mathrm{a}}$ Superintendência do IPHAN, Manaus. Inédito.

Shepard, Glen e Henri Ramires.

2011 "Made in Brazil": Human Dispersal of the Brazil Nut (Bertholletia excelsa, Lecythidaceae) in Ancient Amazonia. Economic Botany, 65(1):44-65.

Shepard, Anna.

1956 Ceramics for the Archaeologist. Washington, D.C.: Carnegie Institution of Washington (Publication n. 609), 1956.

Shiffer, M e J. Skibbo,

1997 The Explanation of Artifact Variability. American Antiquity, 62(1):27-50.

Shock, Myrtle 
Shock, Myrtle, Claide Moraes, Francine Silva, L. Lima, Jaqueline Belletti, Marjorie Lima, M. Cassino, A. Lima.

2013 Initial contributions of charred plant remains from archaeological sites in the Amazon to reconstructions of historical ecology. In: III Encontro Internacional de Arqueologia Amzônica, Quito.

Silva, Fabiola

2000 As tecnologias e seus significados: Um estudo de caso a cerâmica do Xingu e da cestaria dos Kayapó-Xikrin sob uma perspectiva etonoarqueológica. Tese de Doutorado. USP. São Paulo. 2000.

2009 Arqueologia e Etnoarqueologia na aldeia Lalima e na Terra Indígena Kayabi: reflexões sobre Arqueologia Comunitária e Gestão do Patrimônio Arqueológico. Revista do Museu de Arqueologia e Etnologia, v. 19, p. 205-219, 2009.

Silva, Fabiola, Francisco Stuch e Eduardo Bespalez

2011 Arqueologia colaborativa na Amazônia. Amazônica 3 (1): 32-59

Soares, S.M.F

2006 Em Boa Esperança: Momentos da organização social de uma comunidade da Reserva de Desenvolvimento Sustentável Amaná - AM. Dissertação de Mestrado. Universidade Federal do Pará. Belém.

Soares, Iramar.

2006. "Tratamento de dados de intensidade de sinal celular utilizando interpolação".

Souza, Mariana O.

2011 Passar para Indígena na RDS Amanã. Dissertação de Mestrado. Programa de PósGraduação em Antropologia da Universidade Federal de Minas Gerais, Belo Horizonte.

Spix, J.B; Martius, C. F. P.

1981 (1831). Viagem pelo Brasil. Itatiaia Vol. 3. Belo Horizonte.

Steward, J. H.

1948 Culture Areas of the Tropical Forests. In. Handbook of South American Indians, Editor Julian H. Steward - Smithsonian Institution Bureau of American Ethnology, United States Printing Office, Bulletin 143, Vol. 3, Washington. Pp. 883-899

Suzi, Silvana

2014 Variabilidade cerâmica e diversidade Cultural no Alto Rio Madeira, Rondônia.

Tamanaha, Eduardo K.

2012 Ocupação Polícroma no Baixo e Médio Rio Solimões, Estado do Amazonas. Dissertação de Mestrado. Museu de Arqueologia e Etnologia da Universidade de São Paulo.

Tastevin, Constant

[1914] 2008 Preparação e uso da mandioca na região do médio Amazonas e de seus afluentes. Tastevin e a Etnografia Indígena Organizado por Faulhaber, P. e Monserrat, R. Museu do Índio.Rio de Janeiro. Pp 111-119

[1925] 2008 A lenda de Boiaçu na Amazônia. Tastevin e a Etnografia Indígena Organizado por Faulhaber, P. e Monserrat, R. Museu do Índio.Rio de Janeiro. Pp 137-183

[1923] 2008 As inscrições rupestres de La Pedrera (Rio Caquetá, Colômbia). In Tastevin e a Etnografia Indígena Organizado por Faulhaber, P. e Monserrat, R. Museu do Índio.Rio de Janeiro. Pp 184-3196

[1928] 2008 A região do Solimões ou médio-Amazonas (Amazonas, Brasil). In Tastevin e a Etnografia Indígena Organizado por Faulhaber, P. e Monserrat, R. Museu do Índio.Rio de Janeiro. Pp 13-38 
[1929] 2008 A embocadura do Japurá e o Piorini. In Tastevin e a Etnografia Indígena

Organizado por Faulhaber, P. e Monserrat, R. Museu do Índio.Rio de Janeiro. Pp $39-55$

Taussing, $\mathrm{M}$.

1993 Xamanismo, colonialismo e o homem selvagem: um estudo sobre o terror e a cura. Paz e Terra, Rio de Janeiro.

Tully, Gemma

2007 Community archaeology: general methods and standards of practice. Public Archaeology 6(3):155-187

Ugarte, A. S.

2009 Sertões de bárbaros: O mundo natural e as sociedades indígenas da Amazônia na visão dos cronistas ibéricos (séculos XVI-XVII). Manaus: Editora Valer.

Urban, Greg, e Joel Sherzcr.

1988 The Linguistic Anthropology of Native South America. Annual Review of Anthropology 17:283-307.

Van der Leeuw, S.E.

2002 Giving the potter a Choice. Conceptual aspects of pottery techniques. In Techonological Choices. Transformations in material Culturure since the Neolithic. Organizado por Pierre Lemmonier. Routledge, p. 238 - 288.

Van der Leeuw, S. E.; Torrence, R.

1989 Introduction: what's new about innovation? In: What's new? A closer look at the process of innovation Editado por Van der Leeuw, S. E.; Torrence, R. London: Unwin Hyman, p. $1-15$

Vidal, Silvina e Alberta Zucchi

2000 Los caminhos del Kúwai: evidencias del conocimiento geopolítico, de las expansions e migraciones de los grupos arawakos. In: Camuinos pré-colombianos: las vias, los ingenieros y los viajeros. Editado por Leonor Herrera e M. Scrimpff. Instituto Colombiano de Antropología e Hitória. Bogotá. Pp83-113.

Washburn, Dorothy

1983 Symmetry analysis of ceramic design: two tests of the method on Neolithic material from Greece and the Aegean. In Structure and cognition in art (New directions in archaeology). Editado por Dorothy Washburn. Cambridge University Press, Cambridge (1983), pp. 138164

1988 Analysis of pattern structure by geometric symmetries. Textiles as Primary Sources: Proceedings of the First Symposium of the Textile Society of America, Minneapolis Institute of Art.

Washburn, Dorothy e Donald Crowe

1988 Theory and Pactice of plane atten analysis. University of Washington Press, Seattle.

Webster, G. S.

2008 Culture history: a culture-historical approach. Bentley RA, Maschner H.D.G., Chippindale C. (ed.) Handbook of Archaeological Theories. Lanham, AltaMira Press, 2008, p. 11-27

Weinstein, B.

1993 A borracha na Amazônia: Expansão e Decadência (1850-1920). Editora HUCITEC; EDUSP, São Paulo.

Zucchi, Alberta.

2010 Antiguas Migraciones Maipures y Caribes: dos areas ancestrales y diferentes rutas. In: PEREIRA, Edithe e GUAPINDAIA, Vera. (orgs.) Arqueologia Amazônica. v.1. Belém. MPEG; IPHAN; SECULT, 2010.pp. 113-135. 
Anexo 1: Relatórios das datações - Beta Analytic

\section{CALIBRATION OF RADIOCARBON AGE TO CALENDAR YEARS} (Variables: C 13/C 12 $=-26.1$ :lab. mult $=1$ )

Laboratory number: Beta-294196

Conventional radiocarbon age: $1270 \pm 30 \mathrm{BP}$

2 Sigm a calibrated result: Cal AD 670 to 780 (Cal B P 1280 to 1160) ( $95 \%$ probability)

$$
\text { Intercept da ta }
$$

Intercepts of radiocarbon age

Cal AD 710 (Cal BP 1240) and Cal AD 750 (Cal BP 1200) an

1 Sigma calibrated result: Cal AD 680 to 770 (Cal BP 1270 to 1180

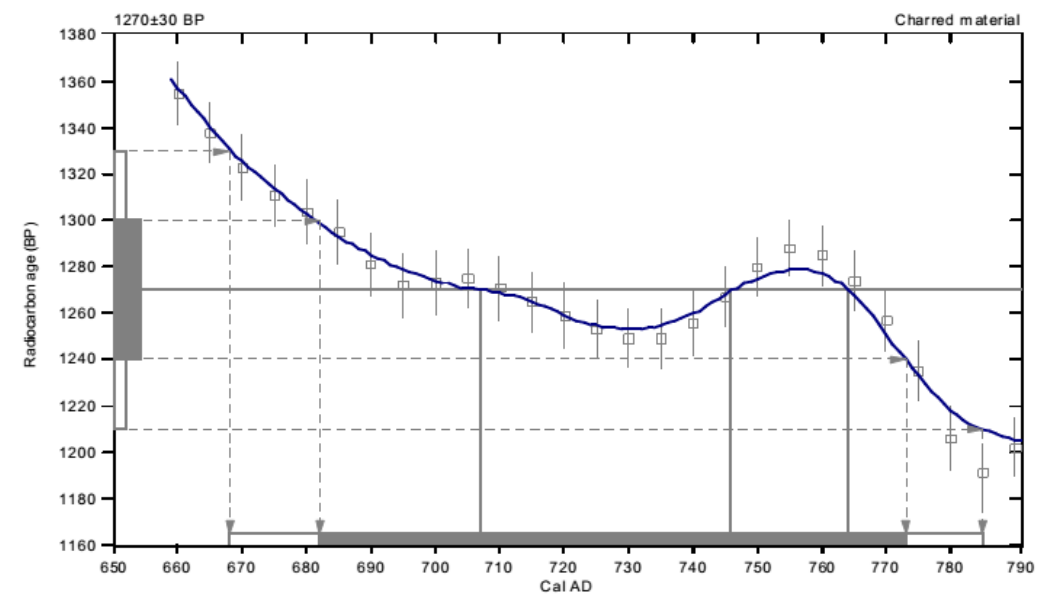

References:
Database

Da tabase used
INTCALO4

Calibration Database
INTCALOA Radiocarbon Age Calibration

A A te Calibration

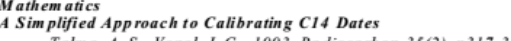

Beta Analytic Radiocarbon Dating Laborator

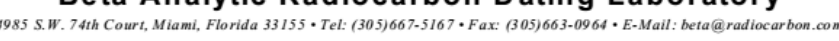

Page 6 of 6

\section{CALIBRATION OF RADIOCARBON AGE TO CALENDAR YEARS}

Nariables: $\mathrm{C} 13 / \mathrm{C} 12=-29.1 \mathrm{o} / \mathrm{oo}:$ lab. mult $=1$ )

Laboratory number Beta-383581

Conventional radiocarbon age $\quad 750 \pm 30 \mathrm{BP}$

2 Sigma calibrated result Cal AD 1270 to 1315 (Cal BP 680 to 635 )

Intercept of radiocarbon age with calibration Cal AD 1285 (Cal BP 665)

1 Sigma calibrated results Cal AD 1280 to 1295 (Cal BP 670 to 655) $68 \%$ probability

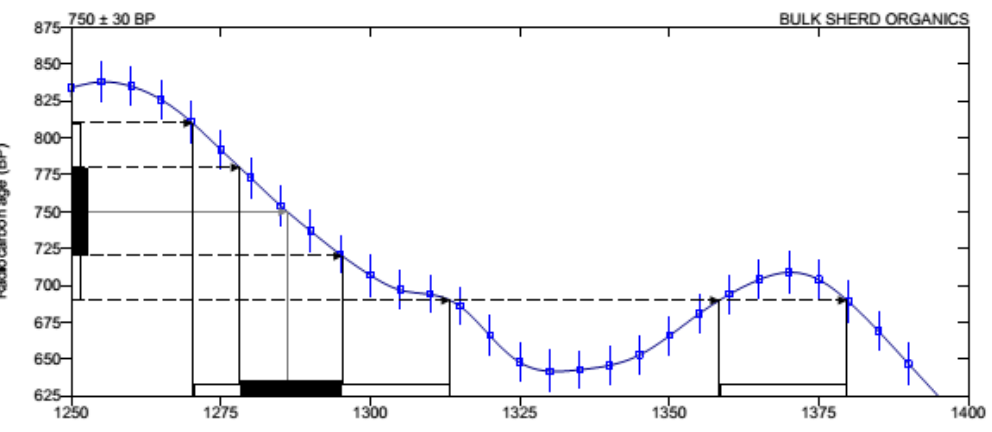

Database used
SHCAL 13

References

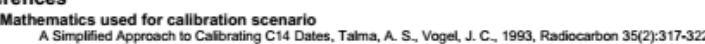

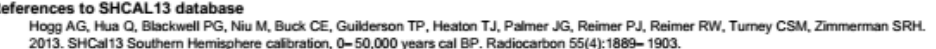

Beta Analytic Radiocarbon Dating Laboratory

4995 S.W. 74 Court Miami Florida 33155 USA. Tet: (305)-667-5167. Fax. (305)-663-0964 - Emali: beta@radiocarbon.com 


\section{CALIBRATION OF RADIOCARBON AGE TO CALENDAR YEARS}

(Variables: $\mathrm{C} 13 / \mathrm{C} 12=-26$ oloo : lab. mult $=1$ )

Laboratory number Beta-383582

Conventional radiocarbon age $\quad 980 \pm 30 \mathrm{BP}$

2 Sigma calibrated result Cal AD 1025 to 1180 (Cal BP 925 to 770)

Intercept of radiocarbon age with calibration Cal AD 1050 (Cal BP 900)

curve Cal AD 1080 (Cal BP 870)
Cal AD 1145 (Cal BP 805)

1 Sigma calibrated results Cal AD 1035 to 1155 (Cal BP 915 to 795 )

$68 \%$ probability

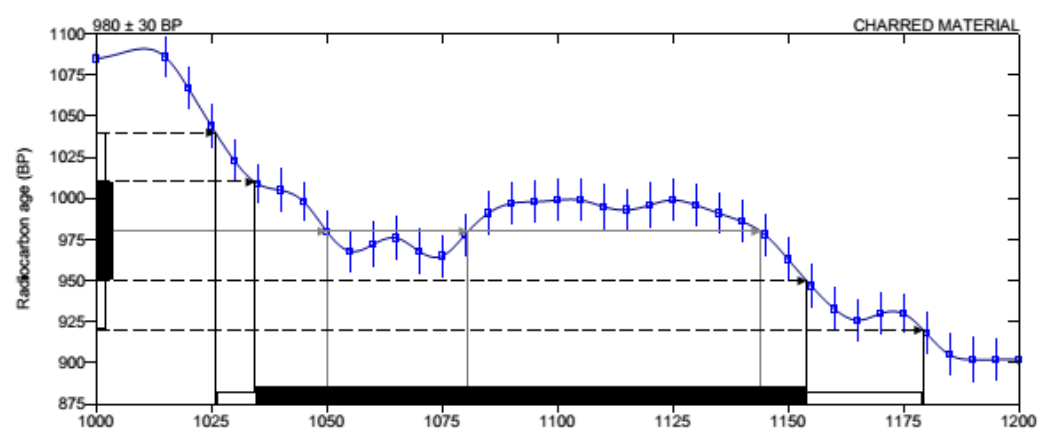

Cal AD

Database used
SHCAL 13

References

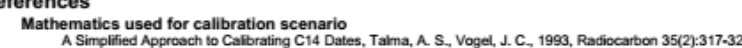

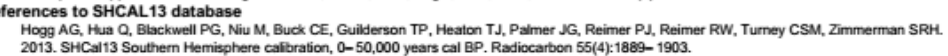

Beta Analytic Radiocarbon Dating Laboratory

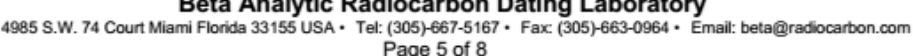

CALIBRATION OF RADIOCARBON AGE TO CALENDAR YEARS

(Variables: C13/C12 $=-30.3 \mathrm{o} / \mathrm{oo}:$ lab. mult $=1$ )

Laboratory number Beta-383583

Conventional radiocarbon age $\quad 2700 \pm 30 \mathrm{BP}$ 2 Sigma calibrated result
$95 \%$ probability

Intercept of radiocarbon age with calibration Cal BC 810 (Cal BP 2760)

1 Sigma calibrated results $\quad$ Cal BC 825 to 800 (Cal BP 2775 to 2750 )

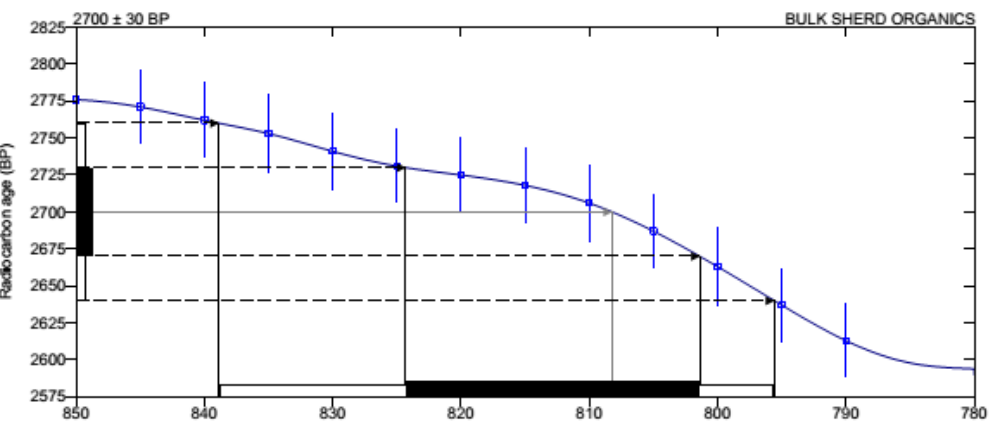

$\mathrm{Ca} B \mathrm{BC}$

\section{Database used
SHCAL13}

Reforences

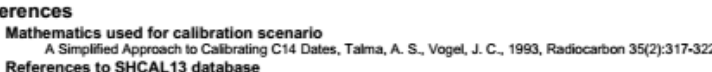

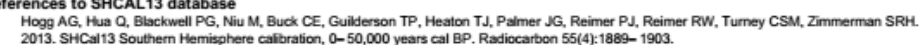

Beta Analytic Radiocarbon Dating Laboratory
4985 s.w. 74 Court Miami Florida 33155 USA. Tel: (305)-667-5167. Fax (305)-663-0964.

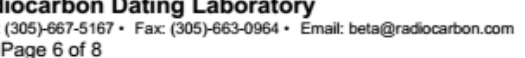


(Variables: $\mathrm{C} 13 / \mathrm{C} 12=-26.10 / 00:$ lab. $\mathrm{mult}=1$ )

Laboratory number Beta-383584

Conventional radiocarbon age $\quad 150 \pm 30 \mathrm{BP}$

2 Sigma calibrated result Cal AD 1675 to 1740 (Cal BP 275 to 210)

95\% probability Cal AD 1800 to Post 1950 (Cal BP 150 to Post 0)

Intercept of radiocarbon age with calibration Cal AD 1710 (Cal BP 240)

curve

Cal AD 1810 (Cal BP 140)

Cal AD 1835 (Cal BP 115)

Cal AD 1845 (Cal BP 105)

Cal AD 1855 (Cal BP 95)

Cal AD 1860 (Cal BP 90)

Cal AD 1865 (Cal BP 85)

Cal AD 1880 (Cal BP 70

Cal AD 1930 (Cal BP 20

Post AD 1950 (Post BP 0 )

1 Sigma calibrated results $\quad$ Cal AD 1685 to 1730 (Cal BP 265 to 220)

$68 \%$ probability Cal AD 1805 to Post 1950 (Cal BP 145 to Post 0)

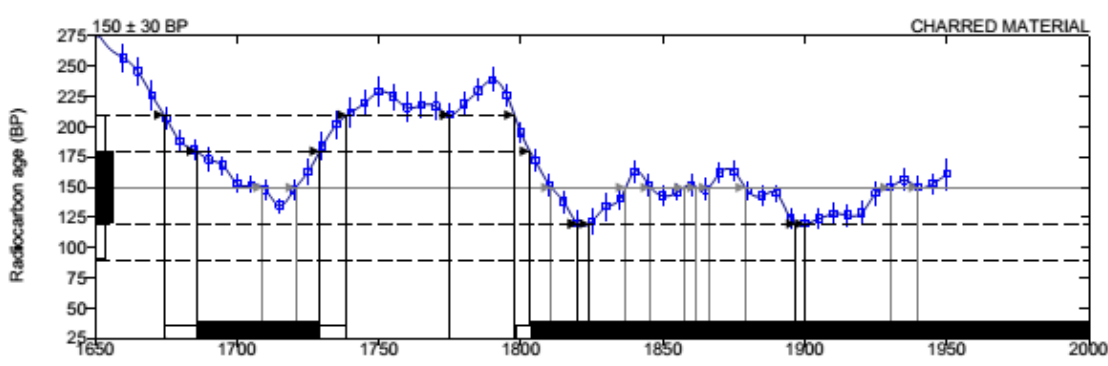

Cal AD

Database used

References

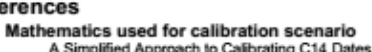

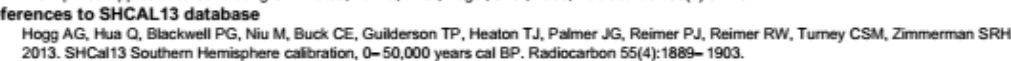

Beta Analytic Radiocarbon Dating Laboratory

4985 S.W. 74 Court Miami Florida 33155 USA. Tel: (305)-667-5167. Fax. (305)-663-0964 • Emall: beta@radiocarbon.com
(Variables: $\mathrm{C} 13 / \mathrm{C} 12=-24.9$ o/oo : lab. mult $=1$ )

Laboratory number Beta-383585

Conventional radiocarbon age $\quad 1240 \pm 30 \mathrm{BP}$ 2 Sigma calibrated result $\quad$ Cal AD 770 to 895 (Cal BP 1180 to 1055)

Intercept of radiocarbon age with calibration Cal AD 880 (Cal BP 1070)

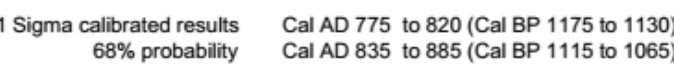

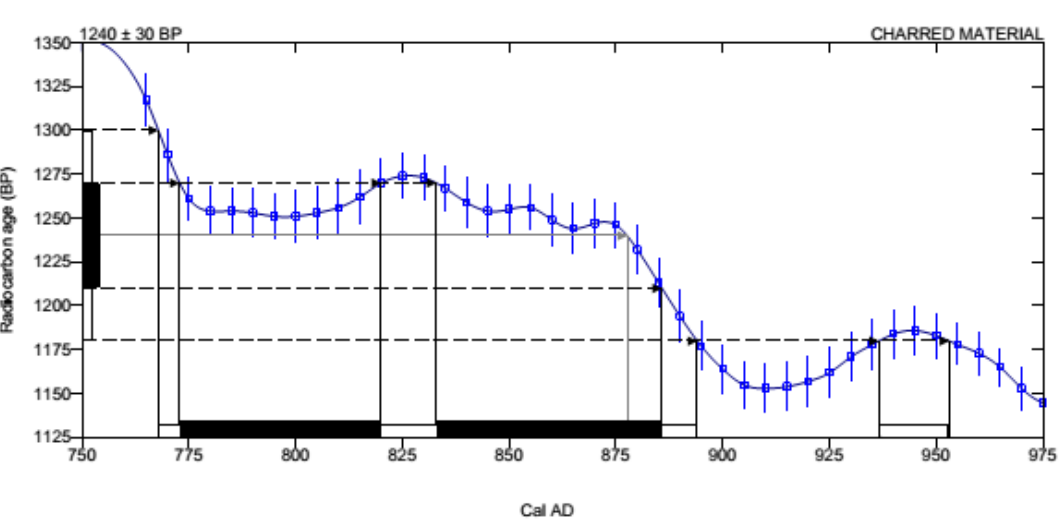

Database used

References

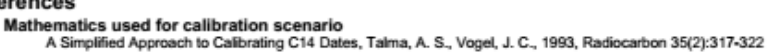

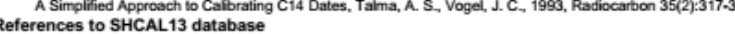

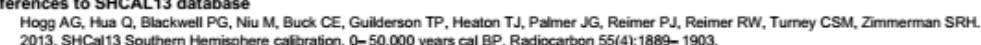

Beta Analytic Radiocarbon Dating Laboratory 4985 S.W. 74 Court Miami Flonida 33155 USA. Tel: (305) 667-5167. Fax: (305)-663-0964 • Email: beta@radiocarbon.com 
(Variables: $\mathrm{C} 13 / \mathrm{C} 12=-26.9 \mathrm{o} / 00:$ lab. mult $=1$

Laboratory number Beta-386834

Conventional radiocarbon age $\quad 1270 \pm 30 \mathrm{BP}$

2 Sigma calibrated result $\quad$ Cal AD 685 to 740 (Cal BP 1265 to 1210)

95\% probability Cal AD 760 to 885 (Cal BP 1190 to 1065 )

Intercept of radiocarbon age with calibration
curve $\begin{array}{r}\text { Cal AD } 775 \text { (Cal BP 1175) } \\ \text { Cal AD 820 (Cal BP 1130) } \\ \text { Cal AD } 835 \text { (Cal BP 1115) }\end{array}$

1 Sigma calibrated results Cal AD 770 to 880 (Cal BP 1180 to 1070) $68 \%$ probability

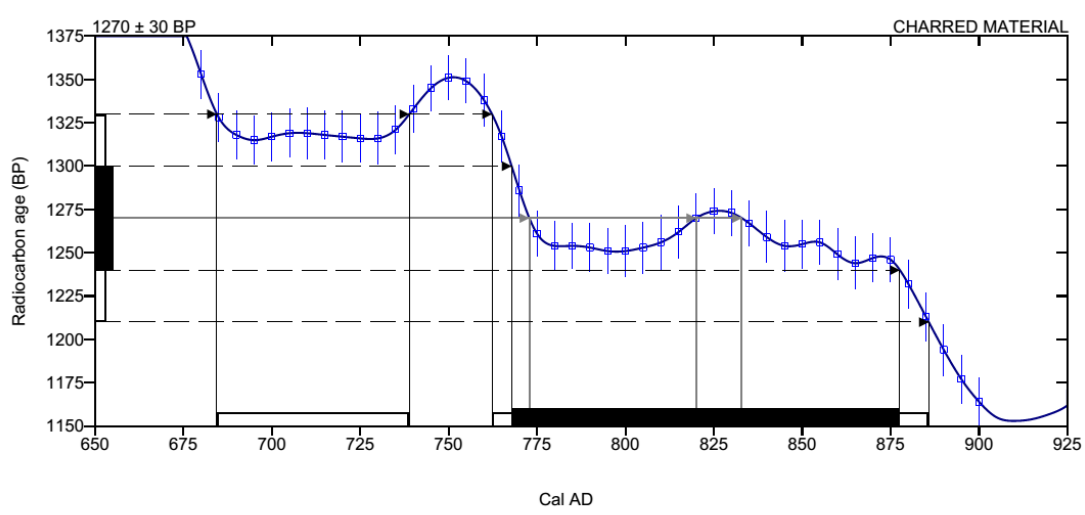

Database used

SHCAL13

References

Mathematics used for calibration scenario

References to SHCAL13 database

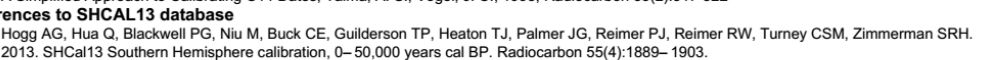

Beta Analytic Radiocabon Dating Laboratory

: (305)667-5167• Fax: (305)663-0964• Email: beta@radiocarbon.com
(Variables: $\mathrm{C} 13 / \mathrm{C} 12=-25.1 \mathrm{o} / \mathrm{oo}:$ lab. mult $=1$ )

Laboratory number Beta-386836

Conventional radiocarbon age $\quad 990 \pm 30 \mathrm{BP}$

2 Sigma calibrated result Cal AD 1025 to 1160 (Cal BP 925 to 790 )

$5 \%$ probability

Intercept of radiocarbon age with calibration Cal AD 1045 (Cal BP 905)

curve Cal AD 1085 (Cal BP 865)

1 Sigma calibrated results Cal AD 1030 to 1150 (Cal BP 920 to 800)

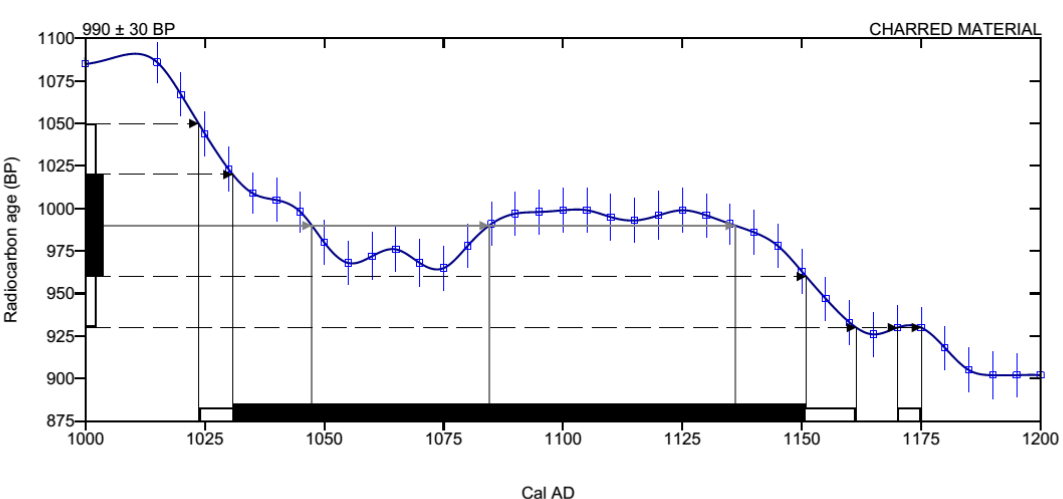

$\underset{\text { Database used }}{\text { SHCAL13 }}$

Rerences

Mathematics used for calibration scenario

S Simplified Approach to to alibrating C14 Dates, Talma, A. S. Vogel, J. . C. 1993, Radiocarbon 35(2):317-322

Hogg AG, Hua Q, Blackwell PG, Niu M, Buck CE, Guilderson TP, Heaton TJ, Palmer JG, Reimer PJ, Reimer RW, Turney CSM, Zimmerman SRH.

Beta Analytic Radiocabon Dating Laboratory
4985 s.W. 74th Court, Miami, Florida 33155 • Tel: (305)667-5167 • Fax: (305)663-0964 • Email: beta@radiocarbon.com 
CALIBRATION OF RADIOCARBON AGE TO CALENDAR YEARS

(Variables: $\mathrm{C} 13 / \mathrm{C} 12=-30.6 \mathrm{o} / \mathrm{oo}:$ lab. mult $=1$ )

\author{
Laboratory number Beta-406073 \\ Conventional radiocarbon age $\quad 1560 \pm 30 \mathrm{BP}$ \\ Calibrated Result (95\% Probability) Cal AD 475 to 605 (Cal BP 1475 to 1345)
}

Intercept of radiocarbon age with calibration curve Cal AD 550 (Cal BP 1400)

Cal AD 560 (Cal BP 1390)

Calibrated Result (68\% Probability) Cal AD 535 to 585 (Cal BP 1415 to 1365)

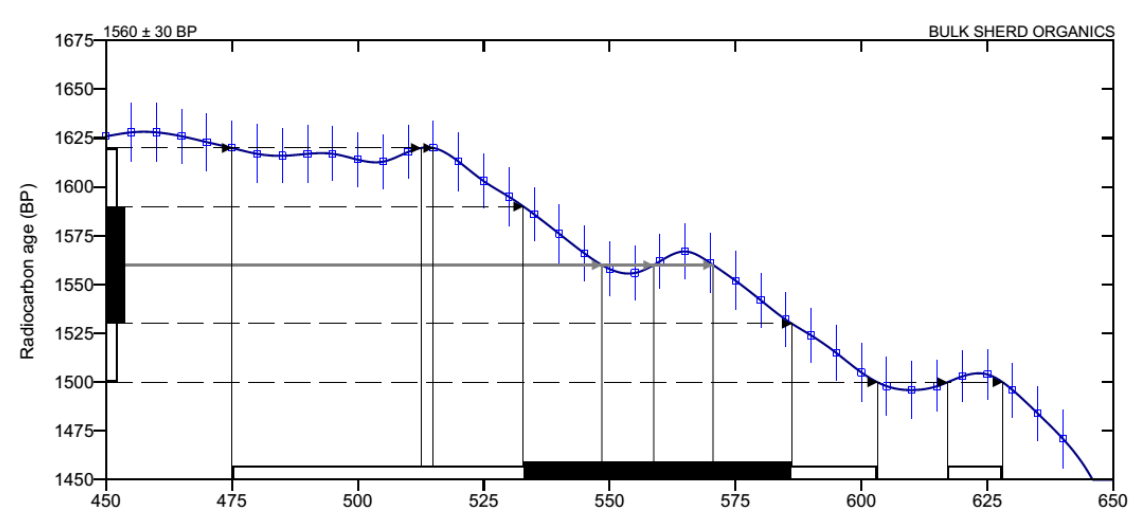

$\underset{\text { SHCAL } 13}{\text { Database used }}$

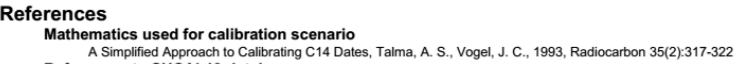

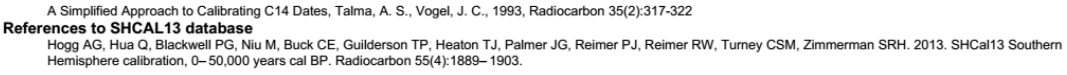

Beta Analytic Radiocarbon Dating Laboratory
4985 S.W. 74th Court, Miami, Florida 33155 . Tel: (3055)667-5167. Fax: (305)663-0964 • Emali: beta@radiocarbon.com 


\section{I) SIT - SÍTIO}

II) PN - DÍGITO

III) LO - LOCALIZAÇÃO

IV) NIV - NÍVEL ESTRATIGRÁFICO

V) NT - NATUREZA DA PEÇA
1-Borda
8- Flange Mesial

2-Base

3-Parede

4- Inflexão 11- Artefato modelado

5-Alça 12-Carimbo

6-Apêndice/Aplique 13-Asa

7-Fuso

VI) ES - ESPESSURA (mm)

VII) DI - DIÂMETRO (mm)

VIII) CS- COR SUPERFÍCIE (interna/externa)

1-Branco/cinza 5-Vermelha/rosada

2-Laranja/bege 6-Marrom

4- Preta 7-Laranja Forte

IX) AP - ANTI-PLÁSTICO

$\begin{array}{lll}\text { 1- Cauixi } & \text { 4-Quartzo } & \text { 8-Osso } \\ \text { 2-Cariapé } & \text { 5-Hematita } & \text { 9-Concha } \\ \text { 3-caco moído } & \text { 6-Argila } & \text { 11-Carvão } \\ & & \text { 12-Areia }\end{array}$

X) TM - TÉCNICAS DE MANUFATURA

1-Roletado 2-Modelado 3-Moldado

\section{XI) QU- QUEIMA}

1-Oxidante 2- Redutora

3-Oxidante Interna/Redutora externa

4-Redutora interna/Oxidante externa

5-Sanduiche (núcleo redutor)

\section{XII) CV - CONTORNO DO VASO}

1-Simples 2-Composto 3-Complexo

XIII) FV-FORMA DO VASO

1-Restritiva 2-Irrestritiva 3-Vertical

4-Ponto de Inflexão

\section{XIV) IB - INCLINAÇÃO DA BORDA \\ 1-Direta \\ 3 - introvertida \\ 2-Extrovertida 4- extrov. tipo flange}

XV) FB - FORMA DA BORDA

$\begin{array}{ll}3 \text { - Roletada interna } & \text { 6- Vazada } \\ 4 \text { - Roletada externa } & 10 \text { - Reta }\end{array}$

5 - Expandida 11- Contraída

XVI) FL- FORMA E ACABAMENTO DO LÁBIO DO

LÁBIO (código antigo)

1-Arredondado 8-Inciso

2-Plano

9(6)-Pintado

3-Biselado 10(7)-Engobo

4-Afilado 11(9)-Acanalado

5(3)-Serrilhado 12(10)-Digitado

6(4)-Ungulado 13(11)-Ponteado

7(5)-Cortado 14(12)-Modelado

15(13)-Exciso

\section{XVII) FB-FORMA DA BASE}

1-Plana 2-Convexa 3-Com pedestal

4-Côncava 5-Plana com marca de folha

6-Plana com marca de esteira

\section{XVIII) TS-TRATAMENTO SUPERFICIE}

1-Alisamento 4-Polimento

2-Enegrecimento 5- Escovado

3-Resina 6-Barbotina (banho)

\section{XIX) LD- LOCAL DA DECORAÇÃO}

1-Interna 4-Flange 7-Borda

2-Externa

5 - Base

3-Ambas

6- Lábio

XX) TD-TIPO E LOCAL DA DECORAÇÃO

1-Dec. Pintada Interna 4- Dec. Plástica Externa

2-Dec. Pintada Externa 6- Engobo Interno

3-Dec. Plástica Interna 7- Engobo Externo
XXI) CE - COR DO ENGOBO

1-Branco 2-Vinho 3-Vermelho

4 - Laranja 5-Amarelo 6-Preto

\section{XXII) TP-TIPO DE PINTURA}

1-Linhas Finas 2-Faixas Grossas 4-pontos

\section{XXIII) COP-COR DA PINTURA}

1-Vinho 4- Amarelo 7-Negativo

2-Vermelho 5-Preto 8-Marrom

3-Alaranjado 6-Branco

\section{XXIV) DP-DECORAÇÃO PLÁSTICA}

1-Acanalado (>2 mm) 8-Esfera Aplicada

2-Inciso

3-Apliques Modelados

9-Impressão de corda

4-Ponteado

10-Corrugado

5-Digitado/Ungulado

6-Roletes aplicados

11- Serrilhado

7-Excisão

12 - Escovado

13 - Raspagem

14-Modelagem livre

\section{XXV) UM- MARCA DE USO}

1-Fuligem (uso) 3- Atrito 4- Fuligem (descarte)

5- Enegrecimento (impregnado na superfície) 
1. $\mathbf{P N}$

2. Suporte/mídia
1. Borda
6. Parede
2. Lábio
7.Base
3. Flange labial 8. Aplique
4. Pescoço 9. Estatueta
5. Flange Mesial 10. Urna

3. Condição

1. Inteiro 2. Fragmento 3. Remontado

4. Grau de conservação

Muito Baixo 12345 Alto

5. Face da decoração analisada

1. Interna 2. Externa

6. Informação da técnica decorativa
1. Pintura
6. Ponteado
2. Engobo
7. Modelado
3. Incisão
8. Incisões múltiplas
4. Incisão dupla 9. Estocado
5. Acanalado
10. Outra

7. Forma gral do vaso / suporte
1. Esférica
4. Vertical
2. Semi-esférica 5.Com Gargalo
6. Irregular

8. Forma do vaso (Shepard)

1. Simples 2. Composta 3. Complexa

9. Distribuição das formas/vaso:
1. Centro
3.Intermediária
2. Descentralizada 4. Periférica
3. Intermediária 5.Total

\section{Conteúdo do desenho}

Código alfanumérico lista anexa

11. Grau de linearidade (Hatcher 1974:63)

1. Linear

2. Principalmente linaer

3. Intermediário

4. Principalmente não-linear

5. Não-linear ou tonal

12. Escala de Linearidade:

Muito curvilíneo 12345 Muito retilíneo

13. Escala de acabamento dos cantos Arredondado 12345 Reto

14. Grau de regularidade do traço Baixo 12345 Alto

15. Relação da figura e fundo
1. Positiva
3. Contrastante
2. Negativa
4. Reversível

16. Grau de Simetria (Shepard 1948 p. 238-242)

1. Balanceado mas não é simétrico

2. Não é muito simétrico

3. Intermediário

6. Quase simétrico

7. Simetria

17. Eixos de simetria
1 Vertical
2. Horizontal
3 Diagonal-Transversal

\section{Padrão}

1. Finito

2. Unidimensional (bandas/faixas)

3. Bidimensional (dois eixos)

4. Tridimensional (três eixos)

19. Grupos de simetria

1. Um 2. Dois ...

20. Movimentos (a partir dos grupos)
1. Reflexão
3. Translação
2. Rotação
4. Translação c. reflexão

21. Estrutura da Simetria (do motivo)

1. Translação

2. Reflexão longitudinal ou horizontal

3. Reflexão vertical/transversal

4. Rotação dupla

5. Reflexões combinadas

6. Reflexão plano-inclinada

7. Rotação alternada e reflexão transversa.

22. Transformações e fusões motívicas

1. Fusão de motivos frequentes

2. Transformação de motivos frequentes

3. Motivo anômalo combinado com motivos frequentes

4. Uso motivo anômalo 
Anexo 4: Tabela identificação dos antiplásticos na amostra de Cacoal do Amanã

Misturas (predominância)

$10-20 \quad 20-30 \quad 30-40 \quad 40-5$

$50-60 \quad 60-70 \quad 80-90$

Cauixi

Quartzo

Caraipe

Cauixi+Caraipé

Cauixi+Caraipé+Carvão+Quartzo

Cauixi+Caraipé+Carvão+Quartzo+Hematita

Cauixi+Caraipé+Carvão+Hematita

Cauixi+Caraipé + Carvão+Argila

Cauixi+Caraipé+Quartzo

Cauixi+Caraipé + Quartzo+Hematita

Cauixi+caraipé+Hematita

Cauixi+Caraipé + Argila

Cauixi +Quartzo

Cauixi+Quartzo+carvão

Cauixi+Quartzo+Hematita

Cauixi+Quartzo+Argila

Cauixi+Hematita

Cauixi+Argila

Caraipé+Cauixi+Carvão+Quartzo

Caraipé+Cauixi+Carvão+Quartzo+Hematita

Caraipé+Cauixi+Quartzo

Caraipé + Cauixi+Quartzo+Hematita

Caraipé + Cauixi + Quartzo+Argila

Caraipé+Cauixi+Hematita

Caraipé+Carvão

Caraipé+Carvão+Quartzo

Caraipé + Carvão + Quartzo+Hematita

Caraipé+Carvão+Quartzo+Argila

Caraipé+Carvão+Hematita

Caraipé + Quartzo

Caraipé + Quartzo+Hematita

Caraipé + Quartzo+Argila

total

Não Identificado

misturas

\begin{tabular}{|c|c|c|c|c|c|c|}
\hline 9 & 1 & 0 & 0 & 3 & 0 & 0 \\
\hline 0 & 1 & 0 & 0 & 1 & 0 & 0 \\
\hline 19 & 0 & 0 & 0 & 1 & 0 & 0 \\
\hline 11 & 1 & 0 & 0 & 0 & 0 & 0 \\
\hline 2 & 2 & 1 & 0 & 0 & 0 & 2 \\
\hline 1 & 2 & 1 & & 1 & & 1 \\
\hline 4 & 0 & 0 & 0 & 0 & 0 & 0 \\
\hline 6 & 0 & 0 & 0 & 0 & 0 & 0 \\
\hline 0 & 8 & 17 & 6 & 2 & 1 & 4 \\
\hline 4 & 12 & 17 & 2 & 7 & 1 & 1 \\
\hline 1 & 0 & 0 & 0 & 1 & 0 & 0 \\
\hline 0 & 1 & 1 & 0 & 0 & 1 & 0 \\
\hline 2 & 13 & 10 & 21 & 10 & 5 & 8 \\
\hline 1 & 0 & 0 & 1 & 0 & 0 & 2 \\
\hline 17 & 33 & 30 & 35 & 49 & 27 & 12 \\
\hline 0 & 5 & 5 & 6 & 7 & 14 & 4 \\
\hline 18 & 6 & 15 & & 19 & & 1 \\
\hline 2 & 0 & 0 & 3 & 6 & 1 & 1 \\
\hline 7 & 5 & 4 & 1 & 5 & 1 & 3 \\
\hline 5 & 0 & 5 & 1 & 1 & 0 & 1 \\
\hline 12 & 7 & 11 & 11 & 3 & 3 & 4 \\
\hline 5 & 9 & 16 & 19 & 8 & 15 & 2 \\
\hline 2 & 0 & 3 & 1 & 2 & 3 & 4 \\
\hline 7 & 0 & 0 & 0 & 0 & 0 & 0 \\
\hline 13 & 1 & 0 & 0 & 0 & 0 & 0 \\
\hline 2 & 15 & 9 & 3 & 4 & 0 & 0 \\
\hline 17 & 20 & 27 & 9 & 10 & 1 & 3 \\
\hline 4 & 1 & 3 & 1 & 0 & 0 & 0 \\
\hline 8 & 1 & 2 & 0 & 2 & 0 & 0 \\
\hline 1 & 15 & 12 & 11 & 1 & 3 & 2 \\
\hline 18 & 31 & 21 & 17 & 9 & 9 & 3 \\
\hline 0 & 2 & 3 & 9 & 2 & 2 & 0 \\
\hline 198 & 192 & 213 & 157 & 154 & 87 & 58 \\
\hline 3 & 0 & 0 & 2 & 0 & 1 & 2 \\
\hline 27 & 23 & 21 & 18 & 23 & 15 & 18 \\
\hline
\end{tabular}


Anexo 5: Tabela frequencia de váriaveis morfológicas - Sítio Cacoal

\begin{tabular}{|c|c|c|c|c|c|c|c|c|c|c|c|c|c|c|}
\hline contorno do vaso & $10-20$ & $20-30$ & $30-40$ & $40-50$ & $50-60$ & $60-70$ & $80-90$ & F1 & $\mathrm{F} 2$ & F3 & F5 & F6 & total & $\%$ \\
\hline simples & 59 & 50 & 59 & 59 & 54 & 31 & 14 & 5 & 3 & 2 & 2 & 11 & 349 & $53,1 \%$ \\
\hline composta & 12 & 13 & 13 & 10 & 6 & 5 & 2 & 0 & 0 & 0 & 1 & 5 & 67 & $10,2 \%$ \\
\hline complexa & 4 & 7 & 7 & 5 & 4 & 1 & 0 & 0 & 0 & 0 & 0 & 0 & 28 & $4,3 \%$ \\
\hline não identificado & 32 & 42 & 49 & 22 & 30 & 16 & 7 & 2 & 5 & 1 & 3 & 4 & 213 & $32,4 \%$ \\
\hline total & 107 & 112 & 128 & 96 & 94 & 53 & 23 & 7 & 8 & 3 & 6 & 20 & 657 & \\
\hline Forma do vaso & $10-20$ & $20-30$ & $30-40$ & $40-50$ & $50-60$ & $60-70$ & $80-90$ & $\mathrm{~F} 1$ & $\mathrm{~F} 2$ & F3 & F5 & F6 & total & \\
\hline restritiva & 17 & 21 & 17 & 13 & 12 & 7 & 1 & 2 & 1 & 2 & 0 & 4 & 97 & $15,8 \%$ \\
\hline irrestritiva & 56 & 36 & 46 & 39 & 43 & 27 & 14 & 2 & 4 & 1 & 4 & 7 & 279 & $45,5 \%$ \\
\hline vertical & 11 & 4 & 11 & 24 & 10 & 9 & 3 & 1 & 0 & 0 & 0 & 4 & 77 & $12,6 \%$ \\
\hline não identificada & 22 & 33 & 44 & 12 & 24 & 9 & 5 & 2 & 3 & 0 & 3 & 3 & 160 & $26,1 \%$ \\
\hline total & 106 & 94 & 118 & 88 & 89 & 52 & 23 & 7 & 8 & 3 & 7 & 18 & 613 & \\
\hline Inclinação da borda & $10-20$ & $20-30$ & $30-40$ & $40-50$ & $50-60$ & $60-70$ & $80-90$ & F1 & $\mathrm{F} 2$ & F3 & F5 & F6 & total & \\
\hline direta & 63 & 52 & 61 & 44 & 58 & 36 & 15 & 3 & 5 & 2 & 3 & 9 & 351 & $54,7 \%$ \\
\hline extrovertida & 25 & 14 & 23 & 27 & 17 & 7 & 2 & 2 & 1 & 1 & 1 & 3 & 123 & $19,2 \%$ \\
\hline introvertida & 5 & 3 & 5 & 2 & 1 & 3 & 0 & 0 & 0 & 0 & 0 & 0 & 19 & $3,0 \%$ \\
\hline extrovertida tipo flange & 6 & 7 & 3 & 10 & 5 & 0 & 4 & 1 & 1 & 0 & 0 & 2 & 39 & $6,1 \%$ \\
\hline não identificada & 22 & 26 & 28 & 10 & 11 & 6 & 2 & 1 & 1 & 0 & 0 & 3 & 110 & $17,1 \%$ \\
\hline total & 121 & 102 & 120 & 93 & 92 & 52 & 23 & 7 & 8 & 3 & 4 & 17 & 642 & \\
\hline forma da borda & $10-20$ & $20-30$ & $30-40$ & $40-50$ & $50-60$ & $60-70$ & $80-90$ & F1 & $\mathrm{F} 2$ & F3 & F5 & F6 & total & \\
\hline roletada interna & 3 & 3 & 3 & 1 & 0 & 0 & 3 & 0 & 0 & & & 0 & 13 & $2,1 \%$ \\
\hline roletada externa & 15 & 14 & 12 & 11 & 5 & 2 & 1 & 0 & 0 & & & 1 & 61 & $9,9 \%$ \\
\hline expandida & 18 & 15 & 25 & 13 & 11 & 6 & 5 & 0 & 1 & 1 & 1 & 3 & 99 & $16,1 \%$ \\
\hline & 40 & 38 & 41 & 39 & 43 & 33 & 8 & 5 & 5 & 2 & 2 & 1 & 257 & $41,8 \%$ \\
\hline contraída & 26 & 24 & 32 & 23 & 30 & 9 & 5 & 2 & 2 & & 3 & 9 & 165 & $26,8 \%$ \\
\hline não identificado & 4 & 1 & 4 & 6 & 0 & 2 & & 0 & 0 & & & 3 & 20 & $3,3 \%$ \\
\hline total & 106 & 95 & 117 & 93 & 89 & 52 & 22 & 7 & 8 & 3 & 6 & 17 & 615 & \\
\hline forma do lábio & $10-20$ & $20-30$ & $30-40$ & $40-50$ & $50-60$ & $60-70$ & $80-90$ & F1 & $\mathrm{F} 2$ & F3 & F5 & F6 & total & \\
\hline Arredondado & 46 & 40 & 49 & 46 & 38 & 18 & 7 & 4 & 3 & 1 & 1 & 7 & 260 & $48,2 \%$ \\
\hline Plano & 25 & 22 & 36 & 17 & 33 & 21 & 5 & 3 & 4 & & 2 & 7 & 175 & $32,5 \%$ \\
\hline Biselado & 0 & 1 & 4 & 4 & 1 & & 1 & 0 & & & 0 & & 11 & $2,0 \%$ \\
\hline Afilado & 16 & 21 & 22 & 8 & 14 & 5 & 3 & 0 & & & 4 & & 93 & $17,3 \%$ \\
\hline total & 87 & 84 & 111 & 75 & 86 & 44 & 16 & 7 & 7 & 1 & 7 & 14 & 539 & \\
\hline acabamento do lábio & $10-20$ & $20-30$ & $30-40$ & $40-50$ & $50-60$ & $60-70$ & $80-90$ & F1 & $\mathrm{F} 2$ & F3 & F5 & F6 & total & \\
\hline Serrilhado & 5 & 2 & 12 & 2 & 5 & 3 & & & & & & & 29 & $26,9 \%$ \\
\hline Ungulado & & 5 & & & & & & & 0 & & & & 5 & $4,6 \%$ \\
\hline Cortado & & & & & & 2 & & & & & 1 & & 3 & $2,8 \%$ \\
\hline Incisão & 3 & 1 & 3 & & & 2 & & & 1 & & & & 10 & $9,3 \%$ \\
\hline Pintura & 1 & 3 & 1 & & & & & & & & & & 5 & $4,6 \%$ \\
\hline Engobo & 7 & 5 & 5 & 1 & 2 & & & & & & & 1 & 21 & $19,4 \%$ \\
\hline Acanalado & & & 2 & 1 & 1 & & & & 2 & & & & 6 & $5,6 \%$ \\
\hline Digitado & & & & & & 1 & & & & & & & 1 & $0,9 \%$ \\
\hline Ponteado & & & & & & & & & 1 & & & & 1 & $0,9 \%$ \\
\hline Modelado & 2 & 2 & 2 & 6 & 2 & 1 & 1 & & & & & 1 & 17 & $15,7 \%$ \\
\hline Exciso & 5 & & & & & 3 & & & & & & 2 & 10 & $9,3 \%$ \\
\hline total & 23 & 18 & 25 & 10 & 10 & 12 & 1 & & 4 & & 1 & 4 & 108 & \\
\hline
\end{tabular}

